\title{
Empirical Evidence on the Effectiveness of Energy Economic Policy Instruments from the Residential and SME Sector
}

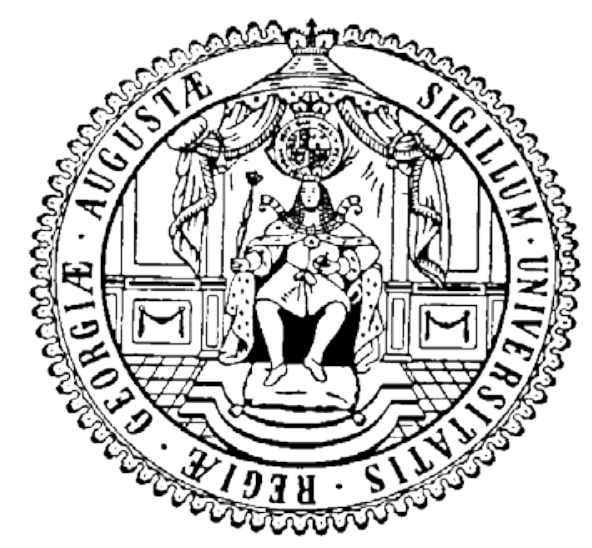

Dissertation

zur Erlangung des wirtschaftswissenschaftlichen Doktorgrades der Wirtschaftswissenschaftlichen Fakultät der Universität Göttingen vorgelegt von

Anita Thonipara

geboren in Mainz

Göttingen, 2020 
Erstgutachter: $\quad$ Prof. Dr. Kilian Bizer

Zweitgutachter: Prof. Dr. Markus Spiwoks

Drittgutachter: $\quad$ Prof. Dr. Stefan Dierkes

Tag der mündlichen Prüfung: 15. April 2020 


\section{Danksagung}

Ich empfinde große Dankbarkeit gegenüber all jenen Personen, die den Weg zur Promotion zu einer schönen, erfahrungsreichen und lebenswerten Zeit gemacht haben und die zum Gelingen der Arbeit beigetragen haben.

Ein besonders großer Dank gilt meinem Doktorvater Prof. Dr. Kilian Bizer, der mich und meine Dissertation stets wohlwollend gefördert und konstruktiv begleitet hat. Insbesondere die Unterstützung zur Teilnahme an internationalen Fachkonferenzen hat zu dem Gelingen dieser Arbeit beigetragen. Prof. Dr. Markus Spiwoks möchte ich ebenso für seine Unterstützung und konstruktive Kritik danken. Prof. Bizer und Prof. Spiwoks möchte ich zudem für die halbjährlichen Kolloquien danken, welche einen konstruktiven Raum für das Gedeihen dieser Arbeit boten. Prof. Dr. Stefan Dierkes danke ich für seine Bereitschaft als Drittgutachter.

Eine Forschungsarbeit ist nie alleine möglich. Deshalb möchte ich mich herzlich bei allen Mitarbeitern des Volkswirtschaftlichen Instituts für Mittelstand und Handwerk bedanken, die einen wunderbaren wissenschaftlichen und sozialen Rahmen gebildet haben, der durch regelmäßiges Feedback und Ratschläge zum Gelingen dieser Arbeit maßgeblich beigetragen hat. Insbesondere gilt mein Dank Dr. Till Proeger, der mir durch seine wohlwollende Unterstützung, konstruktive Rückmeldungen und die mir gewährten Freiräume zur wissenschaftlichen Arbeit, die Realisierung dieser Arbeit ermöglichte. Des Weiteren gilt besonderer Dank Dr. Petrik Runst, der mir das Thema Energieeffizienz nahe gebracht hat und dem ich für seine unermüdliche, motivierende und kooperative Zusammenarbeit, aus welcher ich viel gelernt habe und welche diese Dissertation geprägt hat, danke.

Daneben bin ich weiteren Personen dankbar. Marcel Höhn möchte ich danken, da er mich zu einer Dissertation bewegt und ermutigt hat, stets an meine Fähigkeiten glaubt und mich während des gesamten Promotionsprozesses begleitet und unterstützt hat. Den Teilnehmern des Promovierendenforums bin ich für die Beratung und Unterstützung während des gesamten Promotionsprozesses dankbar. Den Mitarbeitern der Göttinger Graduiertenschule danke ich für unzählige Veranstaltungen, die $\mathrm{zu}$ meiner wissenschaftlichen und persönlichen Weiterentwicklung beigetragen haben. Auch den Teilnehmern der IAEE Konferenzen bin ich des Dankes verpflichtet. Sie haben mich in meiner Forschungsarbeit bestärkt, bestätigt und diese durch kritische Hinweise sowie wertvolle Anregungen verbessert.

Es ist für mich kaum vorstellbar, dass ich die Herausforderungen der letzten Jahre ohne die Unterstützung meiner Familie bewältigt hätte. Ein besonderer Dank gilt deshalb meinen Eltern Angelika und Dr. Johny Thonipara sowie meiner Schwester Sina Thonipara. Sie haben mich auf dem Weg zur Promotion durch Höhen und Tiefen begleitet, mir immer Halt gegeben und mich jederzeit von ganzem Herzen in all meinen Vorhaben unterstützt. Ihnen sei daher die vorliegende Arbeit gewidmet. 
Widmung

Dr. Johny Thonipara

Angelika Thonipara

Sina Thonipara 


\section{Contents}

Chapter I

Introduction and Summary

Chapter II

Energy Efficiency of Residential Buildings in the European Union - An

Exploratory Analysis of Cross-Country Consumption Patterns

Published in: Energy Policy

Chapter III

61

Dosis Facit Effectum - Why the Scope of the Carbon Tax Matters - Evidence from the Swedish Residential Sector

Revise and resubmit in: Energy Economics

Chapter IV

Empirische Hinweise auf die Effektivität einer CO2-Besteuerung im Wohngebäudesektor

Published in: Wirtschaftsdienst

Chapter V

CO2-Bepreisungen in Handwerksunternehmen - ökonomische Szenarien zu Kostenwirkung und Anpassungsreaktionen

Published in: Göttinger Beiträge zur Handwerksforschung

Chapter VI

Drivers of Energy Efficiency in SMEs - Evidence from the German Crafts and Trade Sector

Submitted to: Applied Energy 
Chapter I

Introduction and Summary 
God does not play dice with the universe.

— Albert Einstein (1926)

Yet mankind is playing dice with the natural environment.

—William D. Nordhaus (1993)

Although this quote by Nobel laureate William D. Nordhaus dates to 1993, it is today more relevant than ever. Reports from the International Panel on Climate Change (IPCC), the United Nations Environment Programme (UNEP), the Organisation for Economic Co-operation and Development (OECD), and te International Energy Agency (IEA) warn of impending crises and irreversible losses for humanity and nature caused by climate change. Indeed, climate change is already affecting people and ecosystems around the world, with the past eighteen of twenty years being the warmest years since recording began (IPCC 2018). Although the effects of carbon dioxide $\left(\mathrm{CO}_{2}\right)$ on a warming Earth have been investigated since the 19th century (Fourier 1824; Tyndall 1862; Arrhenius 1896), all the potential effects caused by each additional ton of $\mathrm{CO}_{2}$ emitted into the atmosphere are unknown. Projections and models are subject to many uncertainties and unknown variables. Hence, by further increasing greenhouse gas (GHG) emissions, "mankind is [indeed] playing dice with the natural environment” (Nordhaus 1993, p. 11).

Despite differences in their results, the vast majority of scientists agree that ambitious and sharp reductions in $\mathrm{GHG}$, in particular, $\mathrm{CO}_{2}$ emissions, are necessary (Richardson et al. 2016; Notz \& Stroeve 2016; Sherwood et al. 2014; Nordhaus 2013b; Otto et al. 2013). The Paris Agreement, therefore, set the goal to limit global warming to two degrees, which would require reducing GHG emissions to 45 Gt per year (UNEP 2019). More recent studies, however, stress that to prevent the world from so-called tipping points (with self-reinforcing effects in the climate system), limiting global warming to 1.5 degrees Celsius is necessary (Notz \& Stroeve 2016; Otto et al. 2013). To this end, GHG emissions may not exceed 25 Gt per year.

However, instead of reducing GHG emissions, the world has reached another record high in 2018, with 55.3 Gt of emitted greenhouse gases. Moreover, with the United Nations Climate Conference in Madrid in 2019 failing to decide upon multilateral and globally binding solutions for lowering carbon emissions, the task is left to national energy policies and regional 
initiatives to govern carbon emission reductions. Hence, the new President of the European Commission has declared climate change mitigation as the top priority on the political agenda, to make Europe the first carbon-neutral continent by 2050.

To meet these challenges and goals, policymakers need to know which policy instruments are effective in reducing carbon emissions. This dissertation aims at shedding light on energy economic policy instruments that can play an essential role in the reduction of $\mathrm{CO}_{2}$ emissions and, therefore, in climate change mitigation.

The overarching research question of this dissertation is:

Which energy economic policy instruments are effective in climate change mitigation and lowering $\mathrm{CO}_{2}$ emissions?

To address this question, I focus on two sectors, namely, residential and small- and medium-sized enterprises (SMEs). Regarding the effectiveness of energy policy instruments, studies have focused mainly on transportation and the industrial sector (e.g., Wolff \& Madlener 2019; Zhang et al. 2019; Lin \& Moubarak 2013; Tanaka 2011), while both the residential and the SMEs sector have been neglected. This is probably because the industrial sector accounts for a significant part of $\mathrm{CO}_{2}$ emissions (Odyssee Enerdata 2019). However, the residential and SME sectors play a crucial role in the pursuit of carbon emission reductions in the European Union (EU). The relevance and research context for both sectors are introduced in the following section.

\section{Research Context 1: Residential Sector}

The residential sector was chosen as it accounts for a large part of global $\mathrm{CO}_{2}$ emissions. In the case of the EU, residential carbon emissions make up around $29 \%$ of total $\mathrm{CO}_{2}$ emissions (Odyssee Enerdata 2019). Besides this, residential buildings represent a substantial potential for carbon emission reductions (Petersdorff et al. 2006). The residential sector of the EU is particularly interesting as the EU Roadmap to a low-carbon economy aims for a reduction of residential GHG emissions by 80-95\% below 1990 levels by the year 2050 (European Commission 2011). However, despite a common EU Roadmap and EU directives on energy efficiency in residential buildings (such as directives 2002/91/EC, 2010/31/EU, and 2012/27/EU), each country uses different sets of energy policy instruments to reach the same goal of resi- 
dential carbon emission reductions. This makes the countries of the EU ideally suited for a cross-country comparison regarding the effectiveness of energy policy instruments.

\section{Research Context 2: Small- and Medium-Sized Enterprises}

The second major focus of this dissertation lays on SMEs, in particular small companies. Similar to the residential sector, the SME sector has been neglected by the literature on policy evaluation for carbon emission reductions. However, SMEs represent an important sector to focus on when targeting $\mathrm{CO}_{2}$ emissions as they constitute $99 \%$ of all companies in the $\mathrm{EU}$ (European Commission 2019). Furthermore, SMEs are thus far not subject to the EU Emission Trading Scheme, which is why understanding the effectiveness of policy instruments to reduce carbon emissions in this sector is particularly important. In the literature on SMEs, studies are mostly limited to larger industrial companies with high turnovers, whereas smaller companies with low turnovers are underrepresented. Therefore, I focus particularly on small companies with low turnovers from the German crafts sector.

To understand the economics behind climate change and to place the subsequent analyses of energy economic instruments for climate change mitigation into context, insights into the theoretical groundwork of climate change mitigation and an introduction of policy instruments is provided before giving a summary of the different chapters of this dissertation.

\section{Theoretical Background and Energy Economic Policy Instruments}

First, from an economic perspective, "the greenhouse effect is the granddaddy of public goods ${ }^{1}$ problems" as it is neither possible to exclude individuals from the effect nor is there rivalry in the "consumption” of the greenhouse effect (Nordhaus 1993; p. 18). Each country’s GHG emissions contribute to the cumulative GHG emissions in the atmosphere, which fosters global warming. Costs of abatement, however, pose higher costs than benefits for individuals or individual countries. Hence, incentives to reduce GHG are low for individuals. Instead, there is a strong free-riding incentive for individuals and governments. Free-riding is more attractive than giving up a part of the current wealth "for the sake of uncertain gains in the future” that might not even benefit oneself directly (Grasso 2004, p. 1).

\footnotetext{
${ }^{1}$ Considering the damages caused by the greenhouse effect, it would rather be more suitable to speak of public "bads" than public goods.
} 
Second, GHG emissions result in climate change, which represents a negative externality that Stern (2008, p. 1) argues is "the biggest market failure the world has seen.” Negative externalities that affect the future and yet are not paid for today, represent a market failure. Carbon emissions and other GHG damage society, the environment, and future generations and yet they are not accounted for now by the polluter. Instead, the costs of these damages are borne by the global society, including people and countries that emit relatively few GHG yet are strongly affected by them and may particularly be in future generations.

Hence, an overproduction of GHG emissions results as the costs of the externalities and welfare losses are not part of the price the polluter has to pay for GHG (Kolstad 2011; Nordhaus 1993). Thus, internalization of these external effects is necessary to return to efficient markets. $^{2}$ There are three main internalization approaches relevant for a reduction of GHG emissions, namely social norms, regulatory measures, and market-based instruments (OECD/IEA/NEA/ITF 2015; Mankiw \& Taylor 2006).

In recent years, social norms have become an increasingly applied opportunity for individuals and companies to pay for the external effects one has caused (Horne \& Kennedy 2017). To give an example, flight passengers are willing to pay extra to compensate for the carbon emissions caused by the flight. This dissertation, however, focuses on governmental internalization approaches.

\section{Regulatory Instruments}

Environmental regulatory instruments consist of a wide range of measures including clear technological or emission standards, commanding or prohibiting certain behaviors, and subsidies (OECD/IEA/NEA/ITF 2015). Regulatory “command and control” instruments are characterized by negative sanctions in the case of noncompliance (OECD/IEA/NEA/ITF 2015). Simply prohibiting the emission of $\mathrm{CO}_{2}$ could not be possible as $\mathrm{CO}_{2}$ is emitted as part of basic vital activities (Mankiw \& Taylor 2006). Hence, governments must weigh up costs and benefits to the society to decide upon the amount and the form of $\mathrm{CO}_{2}$ emissions that can be tolerated. By setting clear technological or emission standards, regulatory standards are able to provide certainty about emission levels (IPCC 2007). Although a large number of studies have found regulatory measures to be effective (e.g. Levinson 2016; Ó Broin et al. 2015; Fil-

\footnotetext{
${ }^{2}$ These statements are according to economic theory. There are, however, good reasons to assume that apart from the externalities there are not perfectly functioning, efficient economic systems. 
ippini et al. 2014), these measures are criticized for not being able to keep pace with the dynamic developments of new technologies, which require frequent adaptions to new realities. Besides this, policymakers require a high level of information to justify the promotion or sanctioning of certain technologies or behaviors (Mankiw \& Taylor 2006). In addition, regulatory measures, such as subsidies for energetic retrofitting of homes, are associated with high monitoring and administrative costs (Parker \& Kirkpatrick 2012).

\section{Market-based Instruments}

Instead of using command and control measures, the state can use market-based instruments to balance market incentives with social welfare maximization. A carbon tax puts a price on the externalities of carbon emissions or the externalities of climate change. By increasing the marginal private cost up to a level which equals the actual costs to society, the socially optimal quantity of $\mathrm{CO}_{2}$ emissions will be reduced because larger polluters will have to lower their emissions to stay competitive or maintain living standards (Pigou 1920). In most cases, the carbon tax rate is imposed on the energy carriers according to their carbon content. The carbon tax does not prescribe fixed technological solutions to use; instead, economic entities are free to decide how to save carbon emissions and thereby lower their tax burden (Mankiw \& Taylor 2006). Hence, everyone has the incentive to discover new and cost-effective ways to reduce emissions. This makes the carbon tax more cost-efficient compared to other policy instruments since costs of control and monitoring are reduced to a minimum. However, to find the right price for one ton of emitted $\mathrm{CO}_{2}$ is a fundamentally difficult question as the true cost and (future) damages caused by one ton of $\mathrm{CO}_{2}$ is uncertain.

In the case of emission trading schemes, the quantity of emissions allowed is set by public authorities, while the price is defined by the trade of emission certificates (see Mankiw \& Taylor 2006). Economic entities that can easily reduce their carbon emissions will emit less than the allowed quantity of $\mathrm{CO}_{2}$. These entities can sell their "leftover" rights of carbon emissions to entities for which carbon emission reductions pose higher costs. The advantage of emission trading schemes is that the goal of the targeted emission limit can be easily reached as the quantity is fixed. In the case of a carbon tax, it could be difficult to reach a certain quantity if the demand function, and consequently price, is unknown. On the other hand, a clear price signal has the advantage of predictability for economic entities. 
All these presented policy instruments can be effective in internalizing the external effects and reducing carbon emissions. However, to maximize economic and social welfare while reducing carbon emissions, policy instruments should not only be effective but also efficient. Thus, a policy has to be chosen for which the marginal costs of further GHG emission reductions are equal to the marginal benefit of emissions reductions in slowing climate change (Nordhaus 1993, 1991). Evaluating policy instruments in this regard and presenting empirical evidence from the residential and SME sector is the focus of this dissertation.

This brief overview of the theoretical background on climate change economics and its internalization policy instruments as well as the aforementioned current state of climate change mitigation underlines the relevance of $\mathrm{CO}_{2}$ emission reductions and role of energy economic tools in climate change mitigation. This dissertation presents empirical evidence on the effectiveness of different policy measures, focusing particularly on the effectiveness of carbon taxation in residential buildings and the SME sector. Before presenting the five studies in Chapters II to VI, a summary of each chapter is provided in the following section.

\section{Summary of Chapter II: Energy Efficiency of Residential Buildings in the European Union - An Exploratory Analysis of Cross-Country Consumption Patterns}

To approach the topic of carbon emission reductions, the first paper analyzes the effectiveness of different energy policy instruments in the residential sector of the EU. The EU is an ideal case for this investigation because although there are common EU directives on energy efficiency, there are considerable differences in per capita energy consumption and $\mathrm{CO}_{2}$ emissions across countries in the EU. Earlier studies have categorized and quantified energy policy instruments to allow for their inclusion in quantitative analyses (Ó Broin et al. 2015; Filippini et al. 2014). This approach, however, suffers from the shortcoming that quite distinct policy instruments are treated in the model as if they were identical. Therefore, we conduct an exploratory analysis of cross-country consumption patterns.

To this end, panel data techniques are used to explain per capita country- and year-specific energy consumption as precisely as possible through a number of observable characteristics including, for example, heating degree days (HDD), per capita income, or average floor area. Country dummy coefficients represent the heterogeneity across countries, which capture the effects of country-specific policy measures. Country-specific error terms are interpreted as - 7 - 
country-specific energy efficiency improvements over time as a greater part of per capita energy consumption can be explained by observable characteristics. Countries with strikingly low country fixed effects or decreasing error terms were thereafter analyzed in a comprehensive qualitative analysis.

The results show that Sweden stands out with highly negative coefficients, implying that some Sweden-specific policy must have had a strong negative effect on per capita energy consumption. In addition to Sweden, other EU member states that displayed negative country dummy coefficients were Finland, Bulgaria, and Malta, albeit with a lower value. Furthermore, Latvia and Hungary are analyzed as they show decreasing error terms over time. Using a comprehensive qualitative analysis consisting of in-depth expert interviews, policy papers, legislative texts, and descriptive data, preliminary conclusions are drawn.

First, strict building part regulations are an effective policy instrument for reducing energy consumption in residential buildings. However, the impact of regulatory standards for new buildings and renovations only becomes visible over a long time, as in Sweden or Finland, unless the tightened regulation is accompanied by a building boom as occurred, for example, in Ireland, Latvia, and Hungary. Second, we find evidence for the effectiveness of a carbon tax. As regulatory standards and other factors, such as the performance and share of district heating, are almost identical in the case of Sweden and Finland, another explanation is required to understand the relatively advanced performance of Sweden in comparison to Finland when it comes to energy consumption. The comprehensive qualitative and descriptive analysis suggests that only the carbon taxations' different scopes can explain the strong difference in energy consumption between Sweden and Finland. We finally draw the preliminary conclusion that the effectiveness of carbon taxation is highly dependent on its scope.

\section{Summary of Chapter III: Dosis Facit Effectum-Why the Scope of the Carbon Tax Mat- ters-Evidence from the Swedish Residential Sector}

The second paper, Dosis Facit Effectum [the dose makes the effect] builds upon these results and analyses the effects of the strong carbon tax increase in Sweden in the early 2000s on per capita residential carbon emissions. As one of the first countries to implement a carbon tax scheme and imposing the highest carbon tax in the world (World Bank 2018), Sweden is particularly suited for this analysis. The study focuses on the residential sector as it hasunlike other sectors-always been subject to the full scope of the carbon tax. The carbon tax 
was increased in early 2000 from around 40 Euros to up to around 100 Euros. To investigate the effect of this tax increase, Difference in Differences and Synthetic Control Methods are applied using data of 17 European countries for the years 1990-2016. For both models, we use three samples each consisting of a sample including all countries, a sample of countries that have implemented a carbon tax, and a sample of countries that have no carbon tax in place and no major energy tax increases, thereby allowing comparisons between low- and high-level treatments as well as no-treatment countries.

The results of the Difference in Differences regression suggest a negative impact of carbon taxation on residential carbon emissions with effect sizes between $200 \mathrm{~kg}$ and $450 \mathrm{~kg}$ of per capita $\mathrm{CO}_{2}$ emissions. As the approach suffers from methodological shortcomings, we extend the analysis by a Synthetic Control Model which is ideally suited for the policy evaluation of the carbon tax increase. By constructing a synthetic Swedish residential sector by a weighted combination of the donor countries we can estimate how the Swedish residential carbon emissions had developed in the absence of the policy intervention, hence, the carbon tax increase. The results present evidence for a strong causal impact of the carbon tax increase on residential carbon emissions. The effect reaches $800 \mathrm{~kg}$ of $\mathrm{CO}_{2}$ per capita when compared to nocarbon tax countries and around $300 \mathrm{~kg}$ of $\mathrm{CO}_{2}$ per capita compared to countries with a carbon tax in place. The results remain robust throughout various placebo and robustness tests. As some of the lower-bound estimates are most likely underestimating the true effects and considering that residential per capita carbon emissions are close to 1.75 tons of $\mathrm{CO}_{2}$, the effect size should be regarded as high. By controlling for additional variables in the model, analyzing descriptive statistics, and the potential effects of other policy measures, we rule out the possibility of other confounding factors driving these carbon emission reductions.

Finally, we conclude that carbon taxation can be an effective policy tool in lowering $\mathrm{CO}_{2}$ emissions in the residential sector if taxation levels exceed 120 Euros per ton of $\mathrm{CO}_{2}$, as is the case in Sweden. As the implementation of the carbon tax is widely debated at all political levels, the results present a valuable contribution that can support policymakers in their decisions upon the scope of the carbon tax.

\section{Summary of Chapter IV: Empirical Evidence of the Effectiveness of Carbon Taxation in the Residential Sector (Empirische Hinweise auf die Effektivität einer $\mathrm{CO}_{2}$-Besteuerung im Wohngebäudesektor)}


In Empirical Evidence of the Effectiveness of Carbon Taxation in the Residential Sector, we put the results of Chapter II and Chapter III into a greater energy economic and economic policy framework. To this end, the concept of carbon pricing is first elucidated and compared to other energy-policy instruments currently used by different countries. In a second step, the results of the studies presented in Chapter II and Chapter III are summarized and discussed. Finally, based on the results of the presented studies and the discussion, a fundamental reform and transformation of German climate policy is suggested.

To sum up the first part of this dissertation, it becomes evident that carbon taxation is an effective policy instrument for the purpose of carbon emission reductions. However, the scope of the carbon tax is decisive for its effectiveness. While a carbon tax of around five Euros or 30 Euros cannot be considered as effective, a carbon tax of 120 Euros shows far-reaching effects even in contrast to countries with a relatively high carbon tax of 50-80 Euros. Although regulatory measures are also considered as an effective means to reduce energy consumption and $\mathrm{CO}_{2}$ emissions, these measures are not as efficient as the market-based concept of the carbon tax, which stimulates clean technology innovations while leaving the choice to the end consumers how to save energy and emissions.

The second part of this dissertation focuses on the SME sector and presents evidence on the effects of carbon taxation and the drivers of energy efficiency in SMEs.

\section{Summary of Chapter V: Impact Evaluation- $\mathrm{CO}_{2}$ Pricing and Additional Costs in Crafts Companies (CO $\mathrm{C}_{2}$-Bepreisungen in Handwerksunternehmen - Ökonomische Szenar- ien zu Kostenwirkung und Anpassungsreaktion)}

In early 2019, the implementation of a national carbon tax scheme was the focus of a political debate in Germany. As regulatory measures had not been effective enough in reducing $\mathrm{CO}_{2}$ emissions, market-based instruments were the focus of the debate. Considering this debate and given a lack of studies in this research area, this paper calculates different scenarios for the economic impacts of a carbon tax and the possibilities of adaptation in energyintensive companies of the German crafts sector. We focus on the German crafts sector as this sector consists mainly of small, labor-intensive companies with low turnovers, hence, a group of companies which has so far not been considered in studies of this area.

To calculate the additional costs for companies caused by a carbon tax, we use companylevel data on energy carrier specific energy consumption obtained by the German SME Initia-10 - 
tive Energiewende and Climate Protection. We consider seven energy-intensive occupations (baker, butcher, hairdresser, motor vehicle technician, metal worker, textile cleaner, and carpenters). From the energy carrier-specific consumption, carbon emissions per company can be derived. Hence, the additional costs are calculated by the price of $\mathrm{CO}_{2}$ multiplied by the company-specific $\mathrm{CO}_{2}$ emissions. We use three basic scenarios consisting of carbon tax rates of 40, 60 and 120 Euros. Four additional scenarios are calculated, including compensatory mechanisms through the elimination of the Renewable Energies Act Levy (EEG-Levy) or the full or partial elimination of the energy tax currently in place.

The results show that the carbon tax poses higher additional costs for smaller companies than for larger ones. Depending on the scope of the carbon tax and the branches considered, the additional costs vary between 7 and 1,577 Euros per employee per year. Hence, there is a large heterogeneity in the way companies are affected. A 60 Euro carbon tax would lead on average to 154 Euros in extra costs per employee per year in a company of the considered professions. The scenarios with a full or partial elimination of the energy taxes in place lead in most cases to low or moderate additional costs of less than 100 Euros per employee per year. The scenario including the elimination of the EEG-levy would even lead to economic benefits for most companies even in the case of a carbon tax of 120 Euros. Considering that payment obligations as part of the EEG-levy could be fully covered by a carbon tax of 70 Euros, the scenario of 120 Euros carbon tax and the elimination of the EEG-Levy would be the most feasible and beneficial way for companies of the German craft sector and the environment. Moreover, in relation to total energy costs, the additional costs caused by the carbon tax only account for a small fraction of companies’ total energy outlays.

In a second part of this paper, short-run technical and economically feasible opportunities for adaptation are presented, namely energy efficiency measures or transformation of heat generation. The results suggest that although a considerable part of the additional costs can be saved by these measures, only a few adaptations would be undertaken by the firms in the short run. This is due to high investment costs and long amortization times as well as the comparatively low additional costs caused by the carbon tax.

Once again, this study shows that the scope of the carbon tax matters. Simultaneously, the results show that to reduce carbon emissions, investments in low carbon alternatives must be feasible. Hence the question arises how to promote investments in energy efficiency measures in these SMEs. This question is addressed in the last chapter of this book. 


\section{Summary of Chapter VI: Drivers of Energy Efficiency in SMEs}

After having calculated the effects of carbon taxation on companies in the German crafts sector, the factors promoting energy efficiency measures in these SMEs is of interest. Hence, in this chapter, the importance of different drivers of energy efficiency in SMEs is analyzed. Despite their economic relevance, few studies have investigated drivers of energy efficiency in SMEs, and former studies have focused on larger industrial SMEs with high turnovers. This study focuses on drivers of energy efficiency measures in smaller SMEs with comparatively low turnovers from the German crafts trade. For this purpose, I use exploratory expert interviews and a survey, which I extend by in-depth interviews. The survey is based on a study conducted by Cagno and Trianni (2013) to make the results of two samples (larger, high turnover and smaller, low-turnover companies) directly comparable.

While Cagno and Trianni (2013) argue that energy efficiency measures were mainly driven by financial support programs and other economic drivers as a strategic step towards more competitiveness, the results of this study suggest that managerial characteristics are more important for small companies with low turnovers. This is due to missing in-house capacities in smaller SMEs that require the management's own motivation or environmental sensitivity for energy efficiency measures. Missing in-house capacities are also a reason for the low importance of financial support programs, which are not attractive to small companies due to their high bureaucratic burden. Instead, smaller companies with low turnovers appreciate firm-specific consultancy by external consultants at certain times when replacement investments are necessary. Larger companies, on the contrary, build up long-term, in-house capacities by acquiring general information. These in-house capacities are particularly important for applications for public financial support programs, which are a key driver in larger companies. Given that larger companies are, in most cases, intrinsically motivated and external consultants play a minor role, building up in-house capacities is essential for continuous energy efficiency improvements.

Overall, the results suggest that to reach small companies, policymakers should focus on information campaigns to initiate management's own motivation. Furthermore, public financing programs should be marketed toward smaller companies and customized to their needs, namely, with less bureaucracy and more flexibility. In addition, offering firm-specific consultancy and close companionship for small companies would be effective, whereas for larger compa- 
nies with high turnovers and high-cost investments, general information and support should be used.

The studies presented in this dissertation add to the broad field of climate change mitigation as well as the evaluation of energy policy instruments. This work provides new insights into the effectiveness of different energy policy instruments, particularly for carbon taxation in the residential and SME sectors, and derives policy implications. With increasing pressure on policymakers to reduce carbon emissions and mitigate climate change, the studies are a valuable contribution that can support policymakers in their decisions upon the use of policy instruments. Hence, although uncertainties in the Climate Casino will persist for mankind, the results of this dissertation may improve the odds of rolling the global-warming dice. 


\section{References}

Arrhenius, S. 1896. "On the Influence of Carbonic Acid in the Air upon the Temperature of the Ground.” Philosophical Magazine and Journal of Science. 41 (251): 237-76.

Cagno, E., and Trianni, A. 2013. "Exploring Drivers for Energy Efficiency within Small- and Medium-Sized Enterprises: First Evidences from Italian Manufacturing Enterprises.” Applied Energy 104 (April). Elsevier: 276-85.

Einstein, A. (1926). Letter to Max Born, published in: Irene Born (1971). The Born-Einstein Letters. Walker and Company. New York.

European Commission. 2011. Roadmap for Moving to a Competitive Low Carbon Economy in 2050.

—. 2019. "Energy Efficiency in Small and Medium-Sized Enterprises.” 2019. https://ec.europa.eu/energy/intelligent/projects/en/projects/engine (accessed 13.12.2019).

Filippini, Massimo, Lester C. Hunt, and Jelena Zorić. 2014. "Impact of Energy Policy Instruments on the Estimated Level of Underlying Energy Efficiency in the EU Residential Sector.” Energy Policy 69: 73-81.

Fourier, J.-B.-J. 1824. “Remarques Génerales Sur Les Températures Du Globe Terrestre et Des Espaces Planétaires.” Annales de Chimie et de Physique XXVII: 136-67.

Grasso, M. 2004. “Climate Change: The Public Good.” Working Paper Series Department of Econmoics University of Milan - Bicocca 75.

Horne, C., and E. H. Kennedy. 2017. “The Power of Social Norms for Reducing and Shifting Electricity Use.” Energy Policy 107: 43-52.

IPCC. 2007. Climate Change 2007 - Mitigation of Climate Change. Contribution of Working Group III to the Fourth Assessment Report of the Intergovernmental Panel on Climate Change. Edited by B.; Metz, O.R.; Davidson, P.R.; Bosch, R.; Dave, and L.A.; Meyer. Cambridge University Press. Cambridge and New York.

—. 2018. “Global Warming of $1.5^{\circ}$ C.” IPCC Special Report.

Kolstad, C. 2011. Intermediate Environmental Economics. New York. 
Levinson, A. 2016. “How Much Energy Do Building Energy Codes Really Save? Evidence from California.” American Economic Review 106 (10): 2867-94.

Lin, B. and Moubarak, M.. 2013. "Decomposition Analysis: Change of Carbon Dioxide Emissions in the Chinese Textile Industry.” Renewable and Sustainable Energy Reviews 26 (October): 389-96.

Mankiw, N.G. and Taylor, M. 2006. Economics. 4th ed.

Nordhaus, W. D. 1991. “To Slow or Not to Slow: The Economics of The Greenhouse Effect.” Oxford University Press on Behalf of the Royal Economic Society 101 (407): 920-37. . 1993. "Reflections on the Economics of Climate Change.” Journal of Economic Perspectives 7 (4): 11-25.

—_. 2013. “DICE 2013R: Introduction and User’s Manual.” Yale University Press, no. October: 102. http://www.econ.yale.edu/ nordhaus/homepage/homepage/documents/DICE_Manual_1 00413r1.pdf. (accessed 13.12.2019).

Notz, D. and Stroeve, J. 2016. “Observed Arctic Sea-Ice Loss Directly Follows Anthropogenic CO2 Emission.” Science 354 (6313): 747-50.

Ó Broin, E., Nässén, J.and Johnsson, F. 2015. “The Influence of Price and Non-Price Effects on Demand for Heating in the EU Residential Sector.” Energy 81 (March). Pergamon: 146-58.

Odyssee Enerdata. 2019. “Database.” 2019. https://odyssee.enerdata.net/database/. (accessed 06.12.2019).

OECD/IEA/NEA/ITF. 2015. Aligning Poilcies for a Low-Carbon Economy. OECD Publishing. Paris.

Otto, A., Otto, F. E. L., Boucher, O., Church, J., Hegerl, G., Forster, P.M., Gillet, N.P. 2013. “Energy Budget Constraints on Climate Response.” Nature Geoscience 6 (6): 415-16.

Parker, D., and Kirkpatrick, P. 2012. “Measuring Regulatory Performance. The Economic Impact of Regulatory Policy.” OECD Expert Paper, no. 3. 
Petersdorff, C., Boermans, T. and Harnisch, J. 2006. "Mitigation of CO2 Emissions from the EU-15 Building Stock. Beyond the EU Directive on the Energy Performance of Buildings.” Environmental Science and Pollution Research - International 13 (5): 350-58.

Pigou, A.C. 1920. The Economics of Welfare. London: Macmillan and co.

Richardson, M., Cowtan, K., Hawkins, E. and Stolpe, M.B. 2016. "Reconciled Climate Response Estimates from Climate Models and the Energy Budget of Earth.” Nature Climate Change 6 (10): 931-35.

Sherwood, S. C., Bony, S. and Dufresne, J.L. 2014. "Spread in Model Climate Sensitivity Traced to Atmospheric Convective Mixing.” Nature 505 (7481): 37-42.

Stern, N. 2008. “American Economic Association The Economics of Climate Change Author ( s ): Nicholas Stern Source: The American Economic Review, Vol . 98 , No . 2 , Papers and Proceedings of the One Hundred Twentieth Annual Meeting of the American Economic Association.” American Economic Review: Papers \& Proceedings 98 (2): 1-37.

Tanaka, K. 2011. "Review of Policies and Measures for Energy Efficiency in Industry Sector.” Energy Policy 39 (10). Elsevier: 6532-50.

Tyndall, J. 1862. Further Researches on the Absorption and Radiation of Heat by Gaseous Matter. Contributions to Molecular Physics in the Domain of Radiant Heat. New York.

UNEP. 2019. Emissions Gap Report 2019.

Wolff, S., and Madlener, R. 2019. “Driven by Change: Commercial Drivers’ Acceptance and Efficiency Perceptions of Light-Duty Electric Vehicle Usage in Germany.” Transportation Research Part C: Emerging Technologies 105 (August): 262-82.

World Bank. 2018. State and Trends of Carbon Pricing 2018.

Zhang, H., Zhang, R., Li, G., Li, W. and Choi, Y. 2019. "Sustainable Feasibility of Carbon Trading Policy on Heterogenetic Economic and Industrial Development.” Sustainability 11 (23): 6869. 


\section{Chapter II}

\section{Energy Efficiency of Residential Buildings in the European Union - An Exploratory Analy- sis of Cross-Country Consumption Patterns}

with Petrik Runst, Christian Ochsner and Kilian Bizer

Published in:

Energy Policy, Volume 129, June 2019, Pages 1156-1167. 


\title{
Energy Efficiency of Residential Buildings in the European Union - An Exploratory Analysis of Cross-Country Consumption Patterns ${ }^{1}$
}

\author{
Anita Thonipara*a, Petrik Runst ${ }^{\mathrm{b}}$, Christian Ochsner ${ }^{\mathrm{c}}$, Kilian Bizer ${ }^{\mathrm{d}}$ \\ * Corresponding author \\ ${ }^{a}$ Institute for Small Business Economics at the Georg-August-University Goettingen, Heinrich-Düker-Weg 6, Göttingen 37073, Germany \\ anita.thonipara@wiwi.uni-goettingen.de; +49551/3917 4888 \\ ${ }^{b}$ Institute for Small Business Economics at the Georg-August-University Goettingen, petrik.runst@wiwi.uni-goettingen.de \\ ${ }^{c}$ Institute for Small Business Economics at the Georg-August-University Goettingen, christian.ochsner@stud.uni-goettingen.de \\ ${ }^{d}$ University of Goettingen, Platz der Göttinger Sieben 3, Göttingen 37073, Germany; bizer@wiwi.uni-goettingen.de
}

\begin{abstract}
Despite a common EU directive on energy efficiency in residential buildings, levels of energy efficiency differ across European countries. This article analyses these differences and investigates the effectiveness of different energy efficiency policies in place in those countries. We firstly use panel data methods to explain average yearly energy consumption per dwelling and country by observable characteristics such as climatic conditions, energy prices, income, and floor area. We then use the unexplained variation by sorting between-country differences as well as plotting within-country changes over time to identify better performing countries. These countries are analysed qualitatively in a second step. We conduct expert interviews and examine the legal rules regarding building energy efficiency. Based on our exploratory analysis we draw a number of preliminary conclusions. First, we suggest that regulatory standards, in conjunction with increased construction activity, can be effective in the long run. Second, the results suggest that carbon taxation represents an effective means for energy efficiency. In this regard, the scope of the carbon tax plays a crucial role. We find evidence that a tax of $30 €$ and a tax of $120 €$ per ton of $\mathrm{CO}_{2}$ cause markedly different reductions in energy consumption.
\end{abstract}

Keywords: carbon taxation, energy efficiency, energy conservation, climate policy, residential buildings

JEL codes: H23, K32, P18, Q58

\footnotetext{
${ }^{1}$ This research is based on a project on the effectiveness of a carbon tax funded by the Federal Ministry of Education and Research (BMBF).
} 


\section{Introduction}

As a means of addressing climate change, energy efficiency ${ }^{2}$ of residential buildings is becoming increasingly singled out by EU environmental policy. Residential buildings are particularly important to focus on, since, according to Eurostat (2018), they account for around $25 \%$ of total energy consumption as well as around $20 \%$ of greenhouse gas emissions. EU directives such as the directives 2002/91/EC, 2010/31/EU, and 2012/27/EU of the European Parliament and the Council set minimum standards for all countries of the European Union to improve energy efficiency in residential buildings. More importantly, specific goals are set for the years 2020 and 2030 (20\% and 30\% reduction in energy consumption compared to projections) (EU, 2010; 2012). The European Union's Update of the European Directive on the Energy Performance of Buildings 2018/844/EU further aims at accelerating the cost-effective renovation of existing buildings and the goal of a decarbonized building stock by 2050 (EU, 2018).

While there are common goals, different governments employ different tools in order to reach these target values. Moreover, energy efficiency levels differ vastly across European countries (Filippini et al., 2014). This gives us the opportunity to study the effectiveness of various tools for increasing energy efficiency levels.

Former research has primarily focused on quantifying energy efficiency policies (Ó Broin et al., 2015, Filippini et al., 2014) or focused on the evaluation of only one energy policy instrument such as regulations (Levinson, 2014; Levinson, 2016) or focused on only one part of residential energy consumption such as electricity consumption (Aroonruengsawat, 2012). This, however, went along with a number of limitations such as homogenizing heterogeneous policy instruments, or excluding important policy instruments which are not quantifiable.

Therefore, we take on a different approach in order to explore which factors of energy policy are effective and are able to explain differences in energy efficiency across European countries. By taking on an exploratory and mixed methods approach we shed some light on parts of energy efficiency policies which have earlier been neglected, such as district heating and carbon taxation.

\footnotetext{
${ }^{2}$ In this paper the term energy efficiency improvement is defined as the reduction in energy consumption whilst holding the temperature level constant. Since we control for prices, income (GDP per capita) as well as average size of apartments and other relevant variables which might affect energy consumption, lower energy consumption indicates higher energy efficiency in a country.
} 
Our analysis is divided into two parts, namely a quantitative and an exploratory qualitative part. In a first step, we use panel data techniques (least square dummy variable regressions, or LSDV) in order to explain residential energy consumption (from 2000 till 2015) of European countries by a number of observable characteristics. Country dummy coefficients can be regarded as unexplained between-country-deviations from expected consumption levels (where the expectation is contingent on observable characteristics). In a subsequent qualitative analysis, based on the results of our quantitative analysis, we investigate energy efficiency policies (with respect to residential buildings) in selected countries by conducting expert interviews in these countries and examining official policy documents as well as statistics.

Besides evidence on the effectiveness of regulatory (building efficiency) standards, our exploratory analysis suggests that energy taxes and carbon taxation represent effective means of energy conservation.

\section{Energy Efficiency in Residential Buildings}

An energy efficiency gap, i.e. a gap between what is technologically and financially feasible and the lack of efficiency measures taken by individuals, can theoretically be explained by three factors (Gerarden et al., 2015, 2017). First, there can be market failures, such as information asymmetries (Feser and Runst, 2016). Second, behavioral explanations, such as cognitive limits and heuristics based thinking, have been proposed (Gillingham, 2012). Finally, potential costs can be underestimated because they are hard to measure, such as search costs, thereby overestimating the efficiency gap. Nevertheless, if an efficiency gap exists, energy policy can, in principle, improve upon the status quo. Therefore, empirical evidence on the effectiveness of energy policy instruments is needed.

The literature on the effectiveness of energy policy instruments on energy efficiency in residential buildings is rather scarce. Differences in climatic conditions, levels of income and living area, etc. preclude any simple cross country comparison of energy consumption in the building sector. Some studies circumvent this problem by comparing regulatory standards of new buildings (Schild et al., 2010) although this excludes the great amount of existing buildings which make up most of the overall energy demand. Alternatively, one may control for observable characteristics that are known to influence consumption levels. There are only two major studies which analyze and compare the effectiveness of energy policies on energy efficiency in residential buildings across different countries, namely by Filippini et al. (2014) and 
Ó Broin et al. (2015). Therefore, we will focus mainly on these two studies and explain their approaches fairly detailed since our further analysis is based on these two studies.

The empirical analysis by Filippini et al. (2014) combines an energy demand model which includes climatic conditions, income levels and living area, with a so called frontier analysis. The authors generate six quantitative policy indicators within three main categories. There are (i) regulatory standards (e.g. u-values which set maximum values for thermal transmittance of building parts), (ii) financial / fiscal incentives, and (iii) informative measures based on the cross-country database on energy policies MURE (Odyssee-Mure Database). This approach has two major limitations: firstly, quite distinct policy measures are treated as if they were identical. To give an example, subsidies for specific types of technologies and broader incentives such as energy taxation are put together in one category (ii). Secondly, by simply counting the number of policies there are no weights which signify the relative impact of these measures. Many different kinds of standards fall within the precinct of this category. For example, Filippini et al. (2014) list Sweden as one of the countries with relatively few regulatory standards. But as we will show below, the regulatory standards in Sweden should be seen as the strictest across Europe. In summary, the results suggest that regulatory standards and financial / fiscal incentives affect energy consumption, whereas informative measures do not.

Ó Broin et al. (2015) pursue a similar strategy as Filippini et al. (2014) but introduce a stronger quantitative element in generating the policy indicators. The authors use a panel data set of 15 European countries for the time period of 1990 till 2010. They estimate the determinants of heating energy consumption. Instead of simply counting the number of different types of policies (Filippini et al., 2014; also Bertoldi and Mosconi, 2015) Ó Broin et al. (2015) generate what they call a semi-quantitative index, whereby they apply different impact-weights to different policies in order to include a measure of effectiveness (and the effect size) for different policies. The policies recorded in the MURE database are therefore divided into low, medium and high impact, which correspond to energy savings of $0.1 \%, 0.1-0.5 \%$, and more than $0.5 \%$. Accordingly, each policy is coded as 1,10 or 20 . The semi-quantitative approach thereby transforms a more or less informal expert consensus on the effectiveness of a policy by mapping them onto the numbers 1,10 , or 20 . The resulting semi-quantitative policy indicators also enter the empirical specification as lags (t-1 until t-7) in order to capture medium run effects. There are three policy categories - financial, informative and regulatory. The authors show that regulatory policies impart the greatest effect on energy consumption. In contrast to Filippini et al. (2014), the results indicate a seven year delay in the effectiveness of 
informative measures. Information effect sizes are also relatively small. The authors suggest increased implementation of regulatory measures.

A semi-quantitative approach necessarily emphasizes similarities between heterogeneous policies in order to create a feasible number of categories. To be sure, any process of quantification faces this challenge as the counting of entities (variable values) within constructed categories (variables) always entails some degree of artificially introduced homogenization. Another limitation of the study is the exclusion of certain policies (such as carbon taxation) as they "would already be represented in the energy price time series" (Ó Broin et al., 2015, 220). Yet, the amount of collected energy and carbon taxes does not necessarily correlate with the size of the tax rate. Individuals will adjust their behavior and substitute taxed sources (e.g. coal and oil) in favor of non-taxed or lightly taxed sources of energy. Thus, for countries in which energy and carbon taxes have been in effect for many years (e.g. Sweden), the carbon tax revenue underestimates the full impact of tax based energy policies as oil and coal are no longer in use. In other words, if people have already switched to renewable energy sources a high carbon tax rate is not necessarily mirrored in a high energy price index.

The studies discussed above have made valuable contributions to the literature and it is noteworthy that regulatory measures impart effects on building energy consumption in both of these papers. We base our analysis on the contribution of these two studies and extend their approaches in order to solve some methodical limitations and obtain more precise results.

\section{Quantitative Analysis}

We employ a mixed-methods approach. Our quantitative analysis serves the purpose of explaining energy consumption by country and year by observable characteristics. We pay close attention to country specific effects as they can indicate a higher (or lower) level of energy consumption than we would expect from the vector of observable characteristics. We also plot the country specific residuals over time. Systematic changes over time may indicate improvements or decline in energy efficiency. We then build upon these quantitative insights by qualitatively investigating certain countries, which stand out due to their better-than-expected energy efficiency, in detail. These case studies identify likely (policy) causes for their high levels of energy efficiency or efficiency improvements.

Having data of the 28 countries of the European Union and Norway for sixteen years, we use panel data methods. Our analysis is limited to the time period 2000-2015 due to missing 
data particularly for the countries Latvia, Lithuania, Luxembourg, Malta, Croatia and Bulgaria. Besides this, data on home ownership and energy carrier specific energy prices were not available for most of the countries prior to 2000. The mean energy use per dwelling by country and year (as tons of oil equivalent) represents the dependent variable in our empirical model. As our dependent variable captures all energy use of households it includes water heating, space heating (and cooling) and appliance use. The model takes the following form:

$$
\begin{aligned}
\text { Energy }_{i t}= & \beta_{0}+\beta_{1} \bar{X}_{i t}+\beta_{2} \log (W A P I)_{i t}+\beta_{3} \text { longitude }_{i}+\beta_{4} \text { latitude }_{i}+\beta_{5} \text { country }_{i} \\
& +\beta_{6} \text { year }_{t}+\varepsilon_{i t}
\end{aligned}
$$

In order to capture the country specific effects a least square (country) dummy variable model (LSDV) will be run. Therefore, a country dummy variable country $y_{i}$ is included in the model controlling for time-invariant country-fixed effects. These country dummies show whether a country consumed more or less energy than others after having controlled for country specific conditions. Using a LSDV can also prevent endogeneity caused by omitted variables since it captures all country specific effects. However, in this case we expect that the country specific effects mainly capture public policy differences across countries. It has been shown that cross-country analyses often suffer from omitted variable bias (Ranson et al., 2014). Both Filippini et al. (2014) and Ó Broin et al. (2015) include only a small set of controls. Besides the LSDV approach, we consequently add a number of additional variables, represented by $\bar{X}$, which former studies have found to affect energy consumption.

The vector $\bar{X}$ is composed of the following time-variant explanatory variables: $W A P I_{i t}$ is the weighted average price index which calculates the year specific energy price according to the country's specific energy mix and prices (including taxes and levies). For ease of interpretation we use the logarithm of WAPI.

Furthermore, median age of the population, mean floor area and GDP per capita are included. All three are expected to have a positive impact on energy use. Their squared terms are included as well since we do not expect further positive impact on energy use from a certain floor area or GDP per capita onwards. Share of homes that are owned (as opposed to being rented) is included in the model in order to test for the existence of the Landlord/Tenant Dilemma (Ástmarsson et al., 2013). Moreover, the share of apartments (as opposed to free standing houses) is an important explanatory variable as apartments are more energy efficient due to the lower number of outer walls (EPA, 2011). In order to control for climatic differ- 
ences we use $H D D_{i t}$, longitude $_{i}$ and latitude $_{i}$ as additional variables. $H D D_{i t}$ are heating degree days which is a proxy variable for the country's specific climate, whereas longitude captures possible effects related to continental climates in eastern European countries. We do not use the variable cooling degree days. A report by the European Commission suggests that the contribution of air conditioning to electricity consumption in Europe is negligible (European Commission, 2003). Jakubcionis and Carlsson (2017) state that the proportion of residential energy consumption allocated to cooling in 2012 is less than $0.5 \%$.

The thermal properties of the building stock depend on its age. Therefore, we use the share of newly constructed residential buildings each year in conjunction with the share of buildings after 1980 in order to construct the variable share post80 for all years and all countries. Finally, $\varepsilon_{i t}$ is the error term in this model.

The results of a Breusch-Pagan Test $(\mathrm{p}$-value $=0.000)$ showed that the model contains heteroscedastic residuals. As often observed in panel data, we also detect autocorrelation (Cumby-Huizinga test for autocorrelation, p-value $=0.000$ ). This is due to the country specific effects which are not constant over time. Therefore, heteroscedasticity and autocorrelation robust standard errors are specified in both model specifications.

Furthermore, energy prices are most likely affected by energy demand. In order to address this endogeneity problem Bigano et al. (2006) rely on lagged energy demand and ArellanoBond dynamic panel-data estimations. Although a robustified Durbin-Wu-Hausman test on endogeneity led us to accept the null hypothesis of exogenous prices (WAPI) (p-value = 1.000), we nevertheless use an instrumental variable approach as a second specification in order to safely rule out potential endogeneity.

To that end, the first year lag of the energy prices is used as an instrument for the energy prices. Energy prices were highly correlated with their lags and the lagged energy prices are not endogenous to the demand of energy. We use a two-stage least squares (2SLS) estimator since it is more efficient than ordinary instrumental variable estimators (Cameron and Trivedi, 2010). The first stage regression output shows that the instrument (L1.WAPI) is statistically highly significant and its t statistic is relatively high (t-test $=10.05)$. This confirms the use of our instrument. The second stage replaces WAPI in the structural regression by the predicted values from the first stage regression. As the standard errors are not substantially larger and the t-statistics did not become smaller compared to the original model we can conclude that L1.WAPI is a strong instrument. The strong association between WAPI and its first year lag emphasizes this. Furthermore, a Stock-Yogo weak ID F test defines the critical value to be 
16.38 at a $10 \%$ maximal relative bias toleration. Since we have a minimum eigenvalue statistic of 90.86 and an F-statistic of 25.77 (due to robust standard errors) we exceed the critical value of 16.38 and therefore, can reject the null hypothesis of weak instruments. By including exactly one instrument for one potentially endogenous regressor our model is just-identified.

Consequently, by conducting a 2SLS regression, reverse causality can be circumvented. The second model specification takes the following form:

$$
\begin{aligned}
\text { Energy }_{i t}= & \left.\beta_{0}+\beta_{1} \bar{X}_{i t}+\beta_{2} \log \overline{(W A} P I\right)_{i t}+\beta_{3} \text { longitude }_{i}+\beta_{4} \text { latitude }_{i}+\beta_{5} \text { country }_{i} \\
& +\beta_{6} \text { year }_{t}+\varepsilon_{i t}
\end{aligned}
$$

Where:

$$
\widehat{W A P} I_{i t}=\gamma_{0}+\gamma_{1}\left(\log (W A P I)_{i t-1}+\gamma_{2} \text { exogenous regressors } i(t)+\varepsilon_{i t}\right.
$$

Where:

$$
\gamma_{2}=0
$$

\subsection{Data}

All variables, their sources, and basic descriptive statistics are displayed in Table 1. A correlation matrix can be found in appendix E. The data for energy consumption per dwelling in tons of oil equivalent was obtained by Odyssee-Mure. Odyssee-Mure further provided the data on floor area and HDD. The latter variable is defined as the distance between Temperature Tm and 18 degrees Celsius (weighted by the number of days), if outdoor temperature is 15 degrees or less and zero otherwise:

$$
H D D=\left\{\begin{array}{rr}
\left(18^{\circ} \mathrm{C}-\mathrm{Tm}\right) x \text { days, } & \mathrm{Tm} \leq 15^{\circ} \\
0, & \mathrm{Tm}>15^{\circ}
\end{array}\right.
$$

$$
\text { where: } T m=\frac{\sum(\operatorname{Tmin}+\operatorname{Tmax} / 2)}{\text { \#days }}
$$

Latitude and longitude were taken from the CIA fact book and verified with additional online sources. The median age and GDP per capita were drawn from the Eurostat database. 
Home ownership and the fraction of the population living in apartments (as opposed to free standing houses) are also available at the Eurostat database. However, these two variables do not contain values for each year, especially between 2000 and 2006. We graphically inspected the existence of a time trend in each country. If the slope is close to zero, it can be assumed that no systematic trend exists and the last available value was used for imputation. No more than three years of missing data was filled in in this manner.

The weighted average price index (WAPI) represents energy prices according to the country and year specific energy mix as well as country and year specific prices and taxes on each energy carrier. Therefore, each energy carrier's share of the country's overall residential energy consumption was calculated. Thereafter, annual prices for each energy carrier were deflated to the price level of the year 2010 and denoted in USD. If the prices were only available in other currencies, they were converted to USD using the exchange rate of the respective year. Missing values were carefully imputed for up to three years. If a systematic trend was observable, the value was adapted to the trend otherwise the value of the closest available year was adopted or the mean between two years' values was chosen.

In order to standardize measurement scales, the consumption of oil, coal, gas and electricity was converted to the unit "tons of oil-equivalent" using the IEA unit converter. In addition, different conversion efficiencies of the energy sources were considered, too. Therefore, prices were multiplied by the energy carrier's conversion efficiency factor (Net Calorific Value, or NCV). Finally, annual prices per ton of oil equivalent in USD (and in NCV of one energy carrier) were multiplied by each carrier's share of the total residential energy consumption. Adding up these weighted prices of each energy carrier yields the country and year specific WAPI. The required data was drawn from Odyssee-Mure, Eurostat, IEA, OECD and Statista.

Some country's energy mix includes biomass as a significant source of energy. Due to a lack of data on biomass prices, we did not include biomass in the WAPI calculation. Instead, we allocate the share of biomass to the other energy carriers. Appendix D lists the average share of oil, coal, gas, district heating and biomass across all years (2000-2015). It also lists average prices for all energy sources. It can be seen that the lack of data for biomass prices, and, to a lesser extent district heat prices, results in a potential bias when calculating the overall weighted price index (see last column of appendix D.). In the robustness section of the paper, we address this concern by removing all countries for which our weighted average price index captures less than 65\% of total residential energy consumption (Bulgaria, Croatia, Latvia, Estonia, Lithuania, Romania, Slovenia and Spain). 
One may ask to what extent the WAPI already captures the effect of carbon taxation. We argue that high rates of taxation do not necessarily lead to higher weighted average price levels after a transitional period. In order to avoid high taxation, individuals will adjust their behavior by switching to less $\mathrm{CO}_{2}$ intensive energy carriers (e.g. by installing heat pumps). Therefore, consumption of taxed energy carriers, such as coal and oil, may decrease or these carriers may no longer be in use. As the WAPI represents energy prices weighted by their respective consumption, a high carbon tax rate does not lead to a high value of the WAPI.

In order to construct the variable "share post80", which measures the share of buildings constructed after 1980, we use annual data on newly constructed residential buildings and those constructed after 1980 drawn from the European Commission, Odyssee-Mure and Norway Statistical Offices. Table 1 presents the descriptive statistics and data sources.

Fig. 1 depicts the average annual energy consumption per dwelling and country. One can see that southern countries (e.g. Malta, Portugal, and Bulgaria) consume, on average, less energy than central or northern European countries (e.g. Norway and Finland), presumably due to climatic factors. Lower income countries also seem to display lower energy consumption.

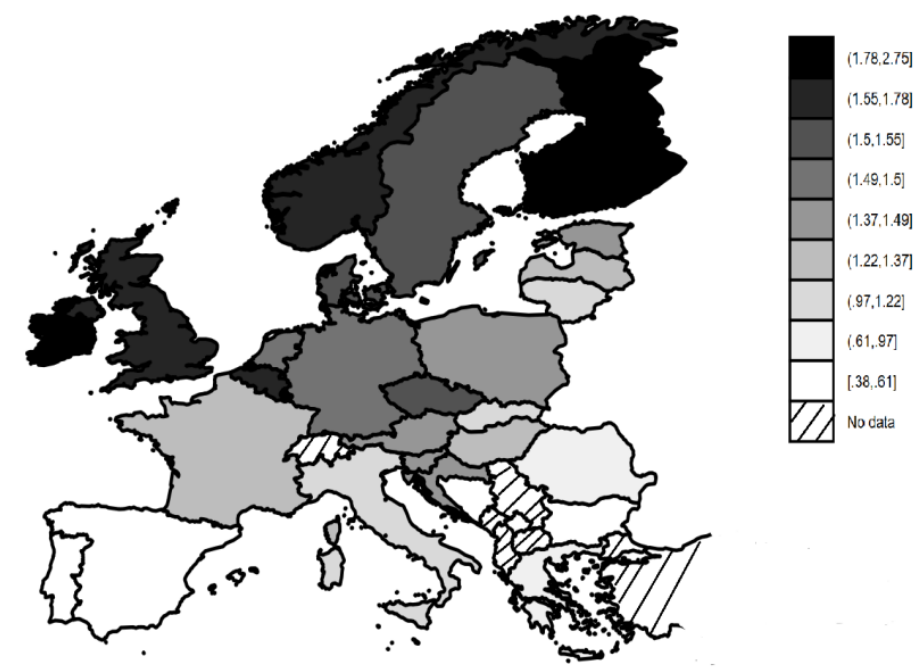

Fig. 1. Average annual energy consumption per dwelling (in tons of oil equivalent, by country) Source: Data drawn from Odyssee-Mure Database

The countries with the highest average consumption per dwelling are Luxembourg, Ireland, Finland and Norway. While the relative position of Finland and Norway is perhaps not surprising, the high consumption countries Ireland and Luxembourg were investigated further in 
order to validate the quality of the data. In the case of Luxemburg, Maas et al. (2007) calculated the average residential energy consumption. The authors concluded that consumption levels are 30 to $40 \%$ higher when compared to Germany or Switzerland. The 2018 report by the Sustainable Energy Authority of Ireland reports that Irish energy intensity per dwelling between 2000 and 2006 is about 25\% higher than the EU average. After 2006 the efficiency gap started to decline (SEAI, 2018, 52).

\subsection{Quantitative Analysis}

Regression results are presented in Table 2. Model specification 1 displays the results of LSDV estimation including country and year dummies. We use heteroscedasticity- and autocorrelation robust standard errors. Specification 2 shows the results of the 2SLS regression using an instrumental variable for energy prices. As expected WAPI has a negative impact on energy use in both specifications. In the LSDV Model a one percentage increase of energy prices leads to a reduction of energy consumption by 0.122 tons of oil equivalent per dwelling. Using lagged prices as an instrument for prices we find that a one percentage increase of energy prices reduces energy consumption by 0.194 toe per dwelling.

The climate control variables HDD, longitude and latitude are all significant in both model specifications. As expected, energy consumption increases with more heating degree days and with increasing latitude. Longitude has a positive impact on energy consumption as well, which suggests that continental climate has a positive impact on energy consumption.

Age is only significant in model 2 and has, unexpectedly, a negative impact; its squared terms are not significant in either model. Floor area and its squared term are significant in both models. If average floor area increases average energy consumption per dwelling increases by 0.0256 toe for each additional square meter. Since its quadratic term is significant and negative, increasing floor area leads to higher energy consumption up to the point at which floor area exceeds about 100 square meters after which consumption is decreasing again. This is most probably due to selective heating of rooms within a large dwelling. GDP per capita is not significant ( $\mathrm{p}$-value $=0.116$ ) but has as expected a positive coefficient. However, the squared terms are significant again and have a negative impact. This means that higher income leads to increasing energy consumption up to a point at which an income of 67,849 Euros is reached. At this point GDP per capita does not have a positive impact on energy consumption anymore. Instead less energy is consumed. The share of owned homes does 
not affect the dependent variable. The Landlord/Tenant Dilemma does not seem to be a major hurdle for the implementation of energy efficiency measures because the coefficient of the variable "home ownership" is not significantly different form zero. The share of apartments affects energy demand negatively in both models. If the share of apartments increases by one percent energy consumption will decrease by 0.0768 toe per dwelling. The share of dwellings built after 1980 is not significant at the $10 \%$ level ( $\mathrm{p}$-value $=0.109)$ and has a negative coefficient.

Overall, our model's explanatory power is very high with an $R^{2}$ of around 0.983 . This is due to the fact that LSDV models capture the effects of otherwise omitted variables. Coefficients of year and country dummies are not listed in Table 2. A negative time trend is observable, which can be explained by technological progress as well as increasingly stringent European energy efficiency policies.

Fig. 2 depicts the country fixed effects sorted from least consuming to most consuming country. The country which displays by far the lowest energy consumption after all observable characteristics (climate, prices, income etc.) are accounted for is Sweden, followed by Bulgaria, Malta and Finland. The two countries which display the highest energy consumption are Ireland and Luxembourg.

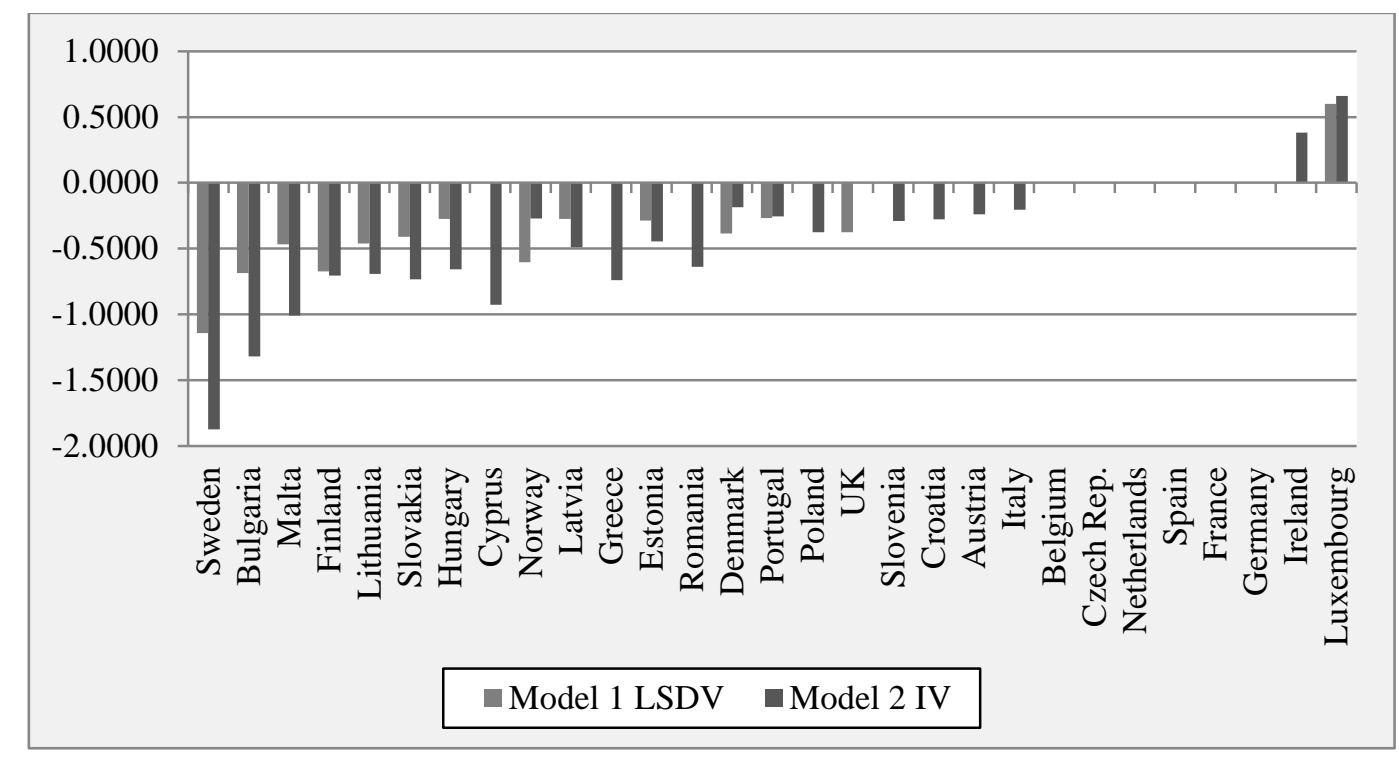

Fig. 2. Country fixed effects after panel regression

Note: Countries with relative low consumption levels (compared to the consumption levels predicted by the explanatory variables) are on the left, whereas countries with higher consumption are placed on the other end of the scale. Country effects which were not significant have a coefficient of 0 . Germany and France are left out as a control group and therefore have a coefficient of 0 as well. Thus, compared to what we would expect Sweden to consume, given its income level, its climatic conditions, average floor area, etc., actual consumption values turn out to be lower than these predicted values. 
Our model results on the relative position of the countries' energy consumption coincide with additional evidence. In particular, the perhaps more surprising cases of Bulgaria (low consumption) and Luxembourg (high consumption) can be validated elsewhere. According to data by the International Energy Agency Database, Bulgaria’s residential energy consumption per capita is only about one third of Germany's, whereas Luxembourg requires 35\% more energy than Germany. A study by the University of Luxembourg (Maas et al. 2007) also concludes that residential energy requirements are 30\% to $40 \%$ above German and Swiss ones.

Finally, Fig. A1 in the appendix depicts the residuals of the model by country over time. While the country dummies have removed mean deviations from the overall energy demands, these graphs can be interpreted as within-country changes over time that are not explained by observable characteristics. The countries which display a clear negative trend over time are Latvia and Hungary as well as France, and Luxembourg to a minor extent.

Falling country specific effects over time are an indicator for the implementation of energy efficiency measures within a country.

\subsection{Robustness Checks}

In this section, we report the results of a number of sensitivity checks (see appendix C). First, we introduced an interaction term between income and the weighted average price index ('Prices x Income', specification 1) as an increase in energy prices could have stronger effects if they make up a large part of household's income. Our main results hold. As in the original results, the Finnish and Swedish country dummy coefficients are strongly negative and significant. Similar to our baseline specification, both countries' residential sector consumes less energy compared to what we would predict based on observable characteristics. Sweden's relative performance is better than the one in Finland.

Second, and most importantly, we dropped countries if their weighted average price index does not cover at least $65 \%$ of the overall residential energy consumption (Latvia, Bulgaria, Croatia, Romania, Estonia, Lithuania, Spain and Slovenia) because, as we have explained above, the biomass, and to a lesser extent, district heat price is not available for all countries and years. We re-ran the LSDV models, also changing the country of reference. In particular, we are interested to see if the relative position of Finland and Sweden in the ranking of country dummy coefficients remains similar to our baseline results. Therefore, we drop the Swedish country dummy (specification 2) and the Finnish country dummy (specification 3) from the regression respectively. Again, our previous results are confirmed. When the Swedish 
country dummy is dropped, Finland displays a higher consumption level - when Finland is dropped, only Sweden and Norway display lower consumption levels. We also present all country dummy coefficients in the appendix (Fig. A2). The rank order of country coefficients does not change much.

In order to control for the effect district heating has on energy consumption we include the share of district heating (as a percentage of the overall energy consumption) in specifications 4 and 5. Our main results remain the same and the district heat variable is not significant.

Finally, specifications 6 to 9 display regression results in which some explanatory variables have been excluded from the analysis. Our main finding persists. The Swedish country dummy coefficient is lower than the one in Finland in all specifications.

\subsection{Summary of Quantitative Results}

The quantitative analysis has shown that Swedish residential energy consumption is lower than what we would expect from observable characteristics such as income, energy prices, climatic conditions etc. We suspect that Swedish energy policy may be the reason for the country's high energy efficiency. Furthermore, the quantitative analysis showed that the Finnish residential sector also consumed less energy than we would have expected given the country specific conditions. However, compared to Sweden, Finland's energy consumption savings are not as high. Being geographic neighbors, Finland and Sweden are situated in a similar climatic and cultural zone and are thus, ideally suited for a direct policy comparison. Considering the similarities of both countries, begs the question, what explains the difference in energy efficiency between both countries. Ireland also represents an interesting case study because of its relatively high energy consumption, as well as Latvia and Hungary due to their decreasing consumption trend found in the plotted residuals. These countries' energy policies will be further analyzed in the qualitative analysis.

\section{Exploratory Policy Analysis}

Qualitative methods are known to generate more detailed information. Therefore, we use qualitative methods in order to explore the countries' energy policies. The qualitative analysis is based on semi-structured in depth expert interviews and extended by an examination of original policy documents as well as research articles. Appendix B summarizes all sources used. The gathered material was evaluated with regard to our research question, i.e. are there 
any distinct policies that may explain the country's low energy consumption level. This analysis is meant to be explorative, whereby we aim to draw preliminary conclusions based upon qualitative evidence which need to be validated in further research.

\subsection{Sweden}

Sweden is an interesting case for our policy analysis because once we take all observable characteristics into account, the Swedish residential sector uses the least amount of energy per dwelling. Descriptive data by the Swedish Energy Agency display a falling total consumption between 1995 and 2008 (see Fig. 3). According to the conducted interviews, three characteristics of Swedish energy policy turn out to be noteworthy: regulatory energy standards for new buildings, the energy and carbon taxation systems as well as district heating.

\section{Energy regulation standards for new buildings}

Swedish energy regulation is quite rigorous, compared with other European countries (see Table 3). This is not only the case for the timespan of our quantitative analysis (2000 - 2015). The regulation from 1978 (SBN 75, Supplement 1) comprises energy requirements that are equal to, or even stricter than those in Germany in 2014 (ENEV 2014). In the meantime, the computational basis for u-values has been altered (BFS 1993; BFS 2002:6) and standards were tightened in 2007 (compare BFS 2006:12 of 2007 as well as BFS 2008:20 BBR 16). 2007's tightening of building part regulation was accompanied by the introduction of a preliminary 2-year license and periodical consumption metering. In the case of non-compliance, owners are fined and buildings have to be modified.

Fig. 3 depicts Swedish total residential energy consumption over time (based on data by the Swedish Energy Agency and Statistics Sweden). As the regulations have been strict since the 1970s and as they have been tightened further in 2007, they cannot be regarded as the main explanatory factor for the decline of Swedish energy consumption between 1995 and 2007 without further qualification. If we put aside the oil price shocks of the 1970s, we can observe that energy demand is on decline since 1995, or, perhaps 1990, whereas it showed no further reaction to the tightening regulation in 2007.

Furthermore, tighter building part regulations may not have been introduced for environmental purposes but for utility maximization. If house owners invest in energy efficiency without being forced by regulation, legal codification would only translate a common practice into formal law. 


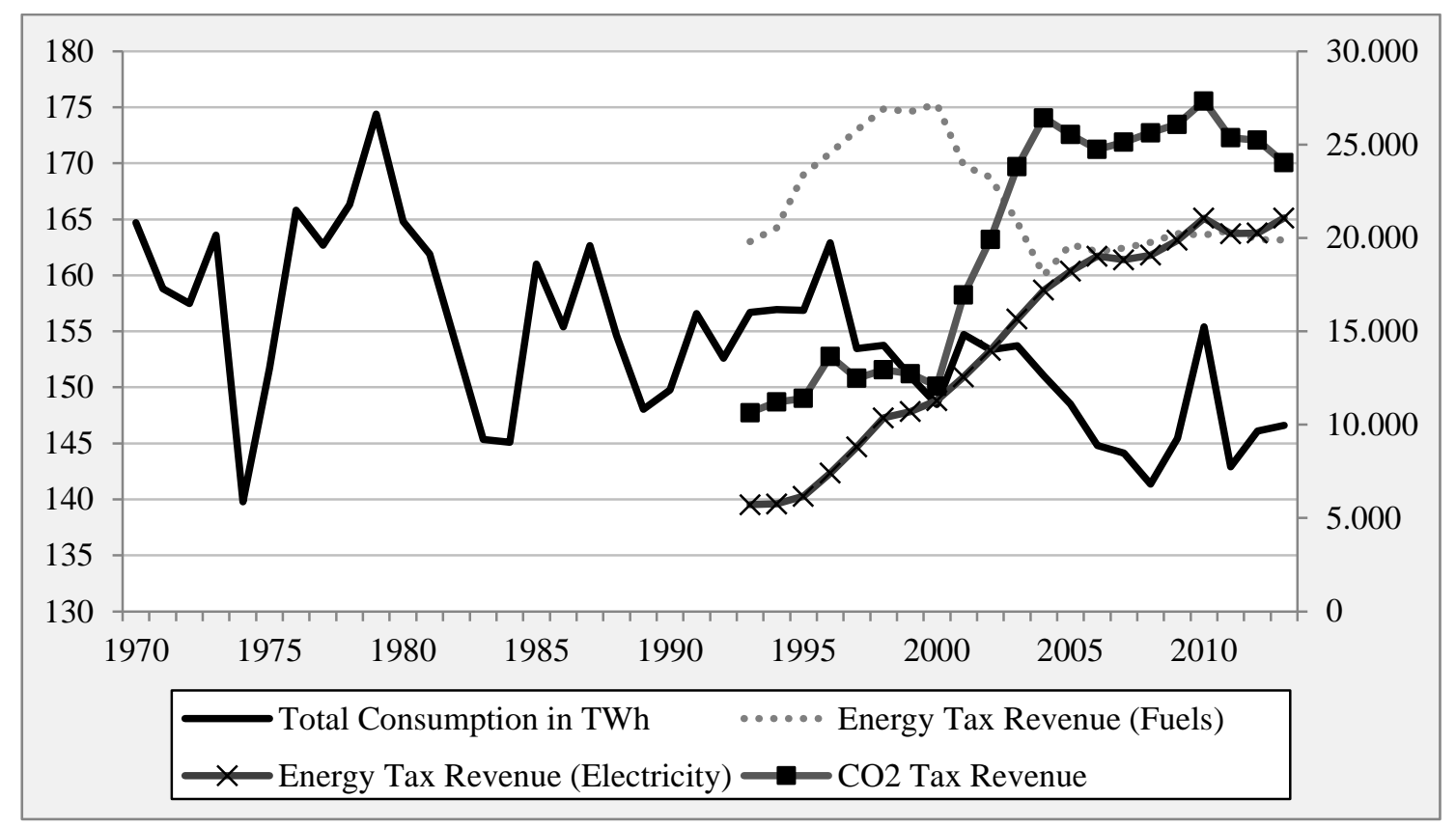

Fig. 3. Total residential and service sector energy consumption (1970-2013, in TWh, left hand axis) and environmental tax revenues in Sweden (1993-2013, in Mio. SEK, right hand axis)

Source: Data drawn from Swedish Energy Agency, Statistics Sweden

\section{Energy and Carbon Taxation}

Fig. 3 shows that a major proportion of energy conservation was achieved from 1995 on and this decline cannot be explained by regulatory reforms or the tightening of building part regulation in 2007 because it was introduced after the major part of conservation had already been achieved. Instead, as we found out in the expert interviews the introduction, and more importantly, the upward adjustment of the carbon tax play a significant role. In 1991, Sweden was one of the first countries to introduce a carbon tax, right after Finland and Poland did so in 1990 (World Bank, 2018). In current prices the tax rate was at $26 € /$ ton of $\mathrm{CO}_{2}$ (GOS, 2018), but in subsequent years it was subject to continuous increases. The highest raise occurred in between 2000 and 2004. Today the price per ton of $\mathrm{CO}_{2}$ is $120 €$ (GOS 2018). The energy- and electricity- as well as the carbon tax revenues are also shown in Fig. 3. The continuous increase of the electricity tax revenue after 1993 and the increase of the carbon tax revenue after 2000 mirror the declining energy consumption trend. The reduction of fuel energy taxation is strongly overcompensated by the increase of electricity and carbon taxation.

Based on our findings we draw the preliminary conclusion that the carbon tax had two major effects: (1) a general reduction in energy consumption and (2) changes of the energy-mix. Especially intensified use of heat pumps (Fig. 4) and the reduction of oil consumption (Fig. 5) 
are presumably caused by the tax increase, which is supported by their co-varying time trends. Interestingly, the spread of heat pumps caused only a very slight increase in electricity consumption after the year 2000 (Fig. 5). Furthermore, the oil consumption reduction is partly compensated by an increase in biomass consumption. The actual increase in biomass consumption is underestimated in Fig. 5, as a large portion of district heat (which is listed separately) is fueled by biomass as well (SEA, 2017).

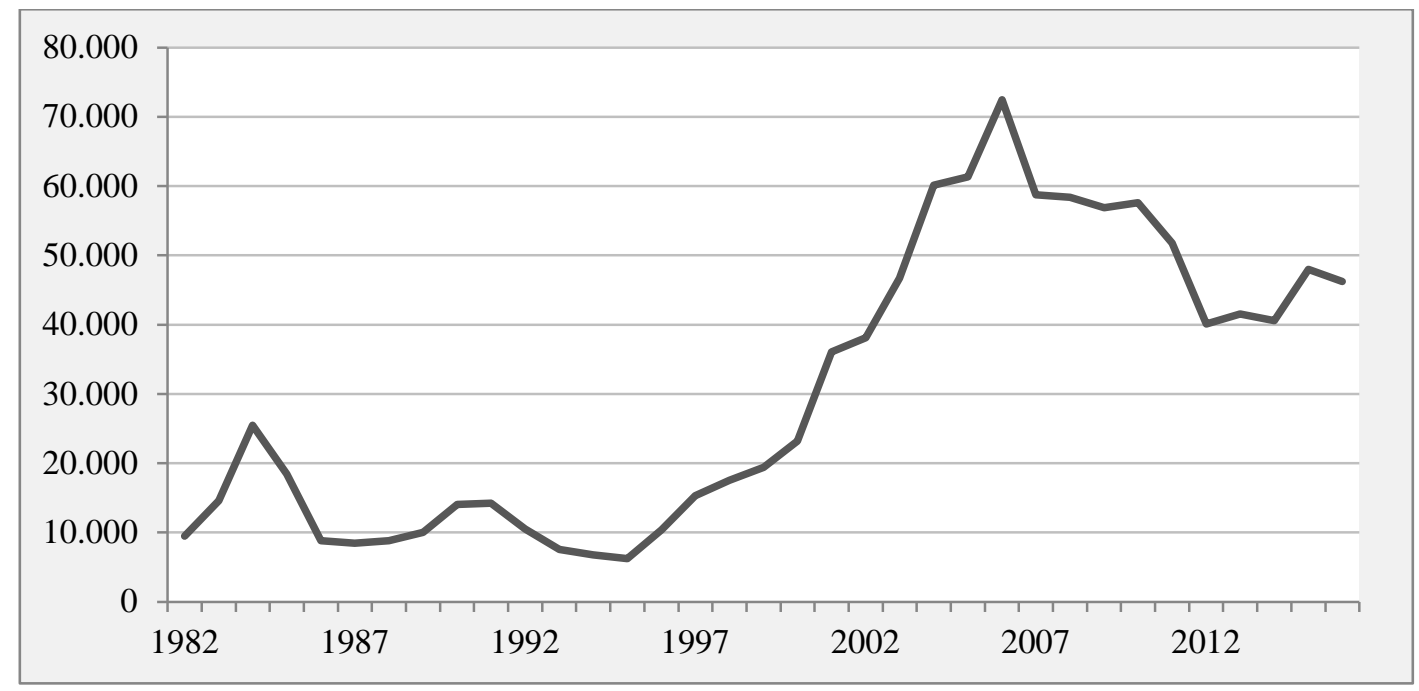

Fig. 4. Sales of heatpumps in Sweden between 1982 and 2016

Source: Data drawn from Svenska Kyl \& Värmepump Föreningen

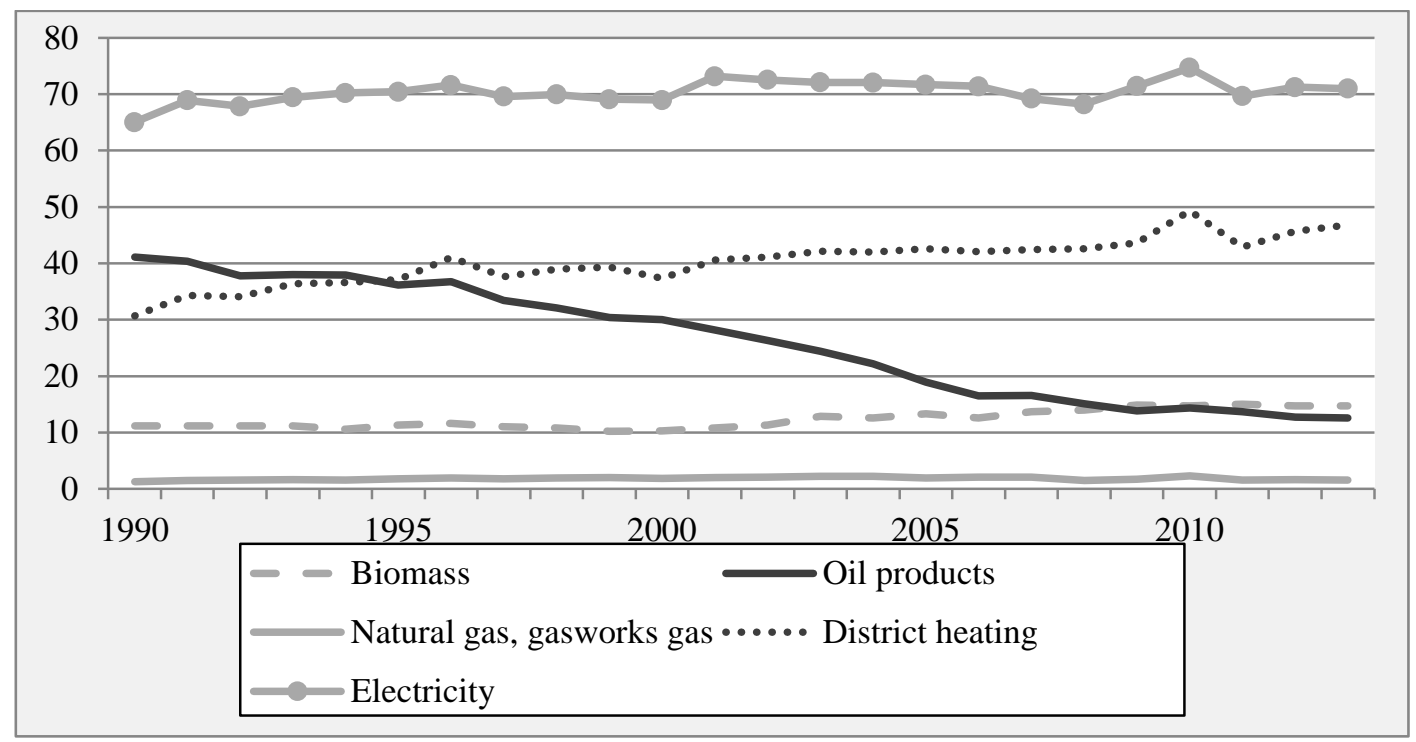

Fig. 5. Residential and service sector energy consumption (households) by energy carrier (Sweden, in TWh)

Source: Data drawn from Swedish Energy Agency 


\section{District Heating}

District heating was mentioned by our interviewees as another factor having improved energy efficiency in Swedish residential buildings. As a reaction to the oil price shocks in the 1970s, a political promotion of municipal district heating occurred. District heating in Scandinavian countries is relatively energy efficient (Joelsson and Gustavsson, 2009). ${ }^{3}$ Due to high energy taxation, the district heat production was incrementally adjusted to include a greater share of renewable energies instead of fossil fuels since the 1990s, which may have been partly caused by higher fossil fuel prices. District heating had a market share of around 55\% in 2014 (Werner, 2017).

Preliminary conclusion 1: Strict regulations are effective in lowering energy consumption.

Preliminary conclusion 2: $\quad$ Carbon and energy taxes are effective in improving energy efficiency by lowering consumption and causing fuel substitution.

Preliminary conclusion 3: The prevalence of relatively efficient district heat systems has caused lower energy use.

\subsection{Finland}

Finnish residential energy consumption is higher than the one in Sweden in both descriptive statistics, as well as in our regression analysis (see Fig. 1 and 2). Descriptive statistics by the IEA (Fig. 6) as well as the residuals in our quantitative analysis (Fig. A1) show hardly any change in total residential energy consumption over time. In the following paragraph we will outline the reasons for Finland's lower, yet, by European comparison still satisfactory, energy performance.

Besides strict regulatory building part energy efficiency regulations (see Table 3), Finnish energy efficiency policy incorporates a range of economic incentives such as energy audits for households or industrial production as well as energy grants for households in order to promote energy efficiency in the old building stock (Lorek and Gianluca, 2015). Like Sweden, Finland also makes extensive use of district heating which has a market share of about $45 \%$ (Sweden: 55\%, see above; Vainio et. al., 2015). Alternatively, country statistics provided by Euroheat \& Power (2013) estimate that about 50\% and 52\% of all customers are served by district heat in Finland and Sweden respectively. The fossil fuel intensity within the district

\footnotetext{
${ }^{3}$ However, district heating is not per se an energy efficient energy carrier. In cases in which pipes are outdated and badly insulated districting heating can lead to an enormous loss of energy. 
heating energy mix and the overall residential energy mix has been declining over the last decade. It is being mostly substituted by renewable and carbon neutral energy sources (SEA, 2017; Statistics Finland, 2018).

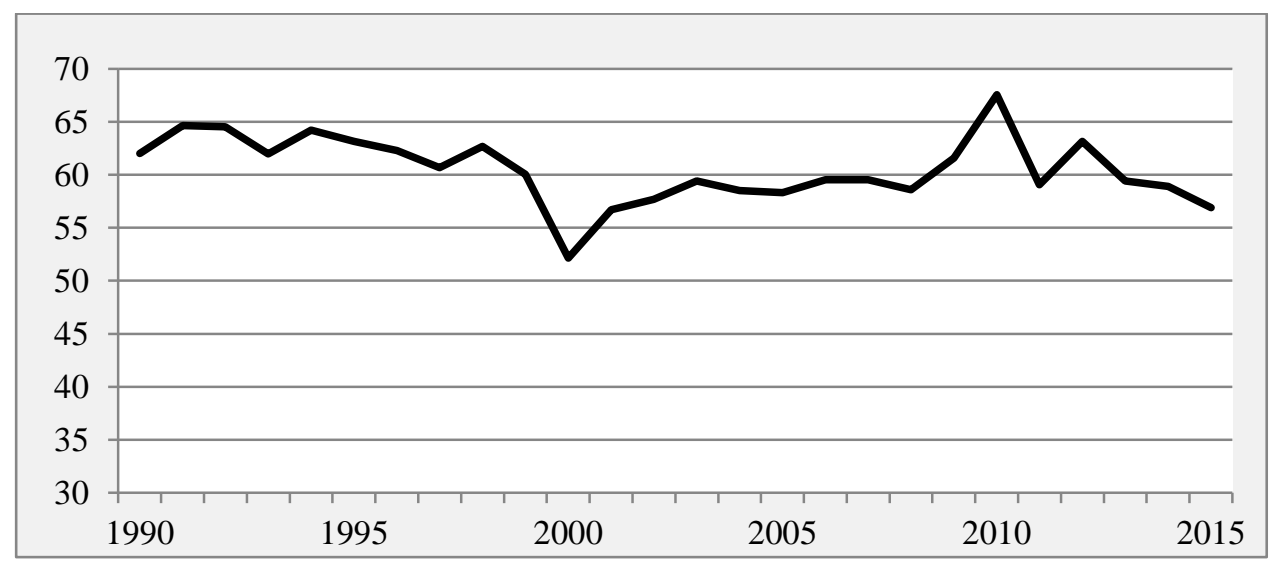

Fig. 6. Total Residential Consumption Finland 1990-2015 (in TWh)

Source: Data drawn from International Energy Agency Database

Thus, Finland makes use of a policy mix that displays remarkable similarities to Sweden's regarding regulations, use of subsidies, and the prevalence of district heating. Therefore, it seems appropriate to expect Finland's residential energy conservation level to be roughly similar to the one in Sweden. Since this is not the case, the discrepancy in energy efficiency performance calls for another explanation.

The expert interviews and our analysis of policies suggest that the main difference between the two countries' energy policy lies in the more stringent carbon taxation in Sweden.

Being the first country to do so, Finland enacted a carbon tax in 1990. This tax has been subject to major reforms of which the merging with the energy tax is of particular importance. Since 1997 the carbon tax also applies to traffic and heating fuels (Bavbek, 2016).

In Finland, different energy carriers are subject to different carbon tax rates, either expressed in c/l (light/heavy heating fuels) or c/kg (coal). Heavy fuel oil and coal make up only an insignificantly small share of the heating energy mix, whereas light fuel oil is the most important fossil energy carrier after wood. If we project the 2015 tax rate for light fuel oil (9,94c/l) to tons of $\mathrm{CO}_{2}$ (Statistics Finland, 2017), it can be concluded that the current carbon tax rate in Finland is set at around $30 €$ per ton of $\mathrm{CO}_{2}$ for light fuel oil. This is, as a World Bank study shows, rather high in international comparison, although the Swedish carbon tax rate is much higher (World Bank, 2015, 15). Lower tax rates are imposed on natural gas, cer- 
tain biofuels, and peat. The relatively lower tax rate, can be regarded as the main factor that distinguishes Finland from Sweden.

In summary, both Finland and Sweden display energy performance levels above what we would predict based on observable characteristics. Their relative position can be explained by tight regulatory standards. Finally, more stringent carbon taxation seems to explain Sweden's more advanced position when we compare the two.

Preliminary conclusion 4: The effectiveness of a carbon tax is dependent on its magnitude. A tax of $30 €$ and a tax of $120 €$ per ton of $\mathrm{CO}_{2}$ cause markedly different reductions in energy consumption.

\subsection{Ireland}

In comparison to Sweden and Finland, Ireland is underperforming when it comes to energy conservation in the residential sector. However, the descriptive data shows a $25 \%$ decline in residential energy use between 2000 and 2015. Thus, while Ireland displays poor energy performance on average, there have been considerable improvements during the last two decades. According to the expert interviews the single most important policy measure is the building part regulation in Ireland, which is currently comparatively strict.

The building part regulation was drastically tightened between 2000 and 2014. Table 4 shows its development over time. It applies to new buildings as well as to renovation for existing buildings, although in the former case, it is more demanding. Between 2000 and 2015, the building stock grew from 1.2 Mio. to 1.7 Mio. permanently occupied buildings. Therefore, a large portion of buildings is subject to the tightened regulations of 2002 and 2007. The average area per building grew during that period, but energy demand per dwelling declined (Irish Energy Agency, 2016). The Irish Energy Agency explains this improvement by the increasing spread of central heating which is more energy efficient than space heating systems.

Carbon taxation was introduced for heating and motor fuels in 2010. Its original rate was set at $15 €$ per ton of $\mathrm{CO}_{2}$, which was raised to $20 €$ per ton in 2012 (Conefrey et al., 2013). Descriptive statistics show a marked decline in total energy use after 2010 despite the general increase in living space (Irish Energy Authority, 2016, 65-66). While this may indicate an impact of carbon taxation, the intervention is too recent in order to draw more definite conclusions. 
The case of Ireland illustrates that hard building regulations are only effective in the long run. Because of the building boom, about a third of the Irish building stock was built after the year 2000, thereby being subject to current energy efficiency standards. Nevertheless, the average Irish energy consumption level is still higher than in most European countries.

Preliminary conclusion 5: Stringent building regulations are only effective in the long run.

Preliminary conclusion 6: Tighter regulations are most effective when accompanied by high construction activities in the residential sector.

\subsection{Latvia and Hungary}

Our quantitative analysis has shown that among all countries Latvia and Hungary both occupy middle positions with regard to their energy consumption level. Yet, both countries show the strongest improvements in energy efficiency over the years. The residential energy consumption pattern in both countries moves almost parallel. Overall, Latvia's as well as Hungary’s total residential energy consumption fell between 1990 and 2016 (Fig. 7). In our regression analysis above, after having controlled for a number of key observable characteristics, we can see that energy efficiency has improved in the years from 2000 onwards (see Fig. A1).

From 1980-1991 buildings in Latvia and Hungary were built according to USSR Standards (for u-values see Table 3). After their independence, the Ministry of Architecture and Construction imposed considerably stricter energy efficiency standards in Latvia in 1991 which were again tightened by the Cabinet Regulation No 495 (LBN 002-01). The latter regulation came into force in 2003 and set construction standards for new buildings, as well as reconstructed and renovated buildings. The u-values from 2003 are not as strict as in Sweden or Finland but roughly correspond to standards in Germany in 2014. Similarly, building regulation in Hungary was tightened in 1991, and again in 2006. Hungary’s regulatory demands are slightly weaker than the ones in Latvia (see Table 3). 


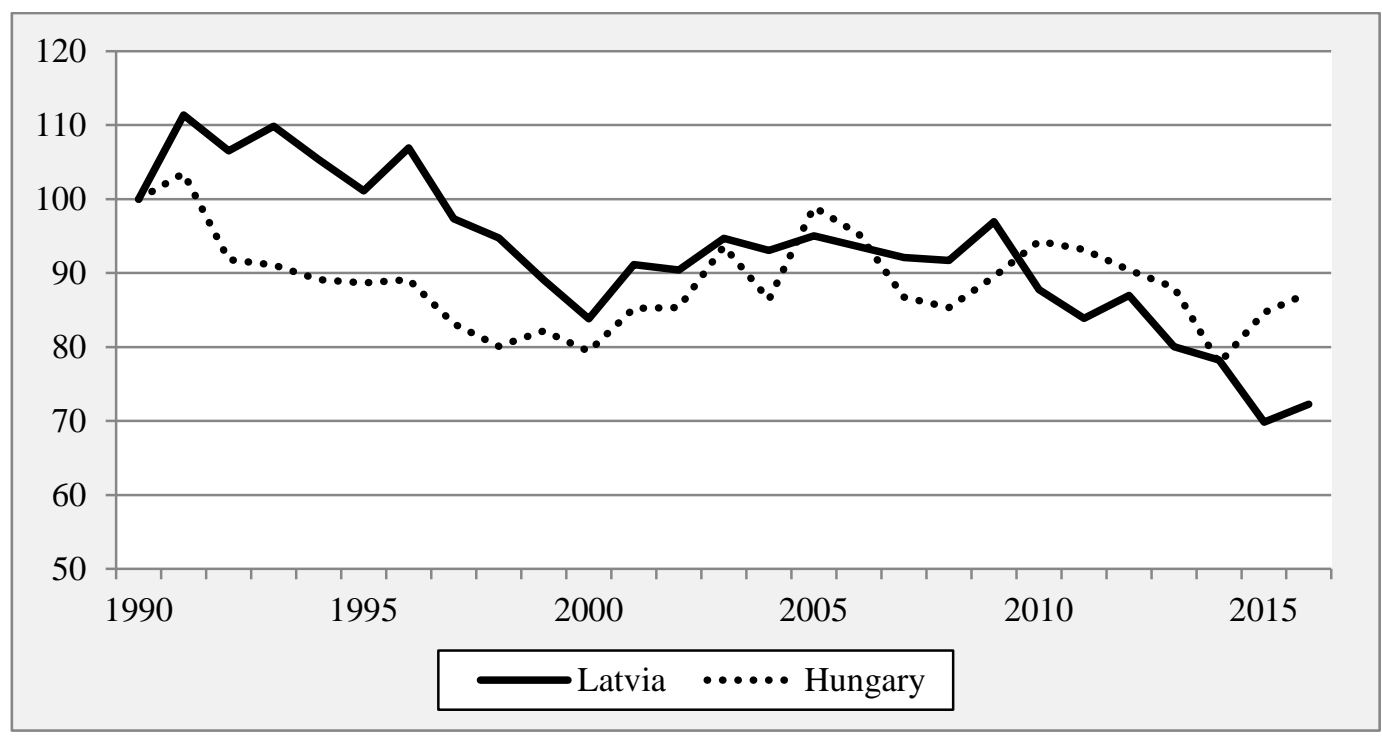

Fig. 7. Residential Energy Consumption in Latvia and Hungary (1990-2016, Index: 1990=100) Source: Data drawn from Eurostat Database

As Fig. 7 depicts, total energy consumption in Latvia and Hungary already had a decreasing trend in the 1990s which could be due to the introduction of stricter standards in both countries at that time in 1991 (see Table 3). However, construction activity was low in the 1990s (see Fig. 8) and thereby regulatory building standards do not translate into improved efficiency performance. Instead there was a massive post-socialist GDP per capita slump in the early 1990s followed by a gradual recovery (Eurostat Database). Thus, the reduction in energy consumption can most probably be explained by low incomes.

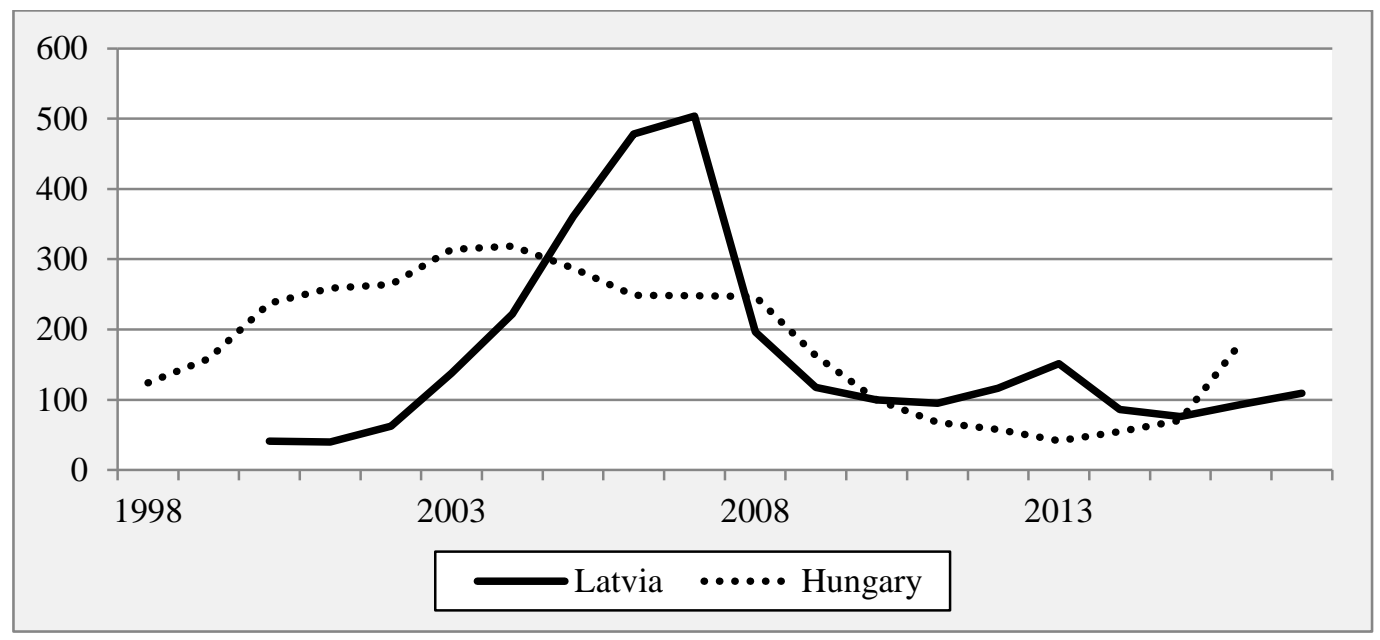

Fig. 8. Total number of new residential dwellings in Latvia and Hungary over time (Index: 2010=100) Source: Data drawn from Eurostat Database, Centralas statistikas parvaldes datubazes 
In the year 2003, when construction standards LBN 002-01 came into force in Latvia, the number of new dwellings skyrocketed till the financial crisis in 2008 (Fig. 8). The sudden increase in construction activity correlates with the steady and strong GDP growth starting in 2003. Similarly, Hungary experienced a building boom starting in 1999 as GDP per capita increased continuously (Eurostat Database). The building boom coincides with a temporary increase in energy demand, which plateaus in 2004 and then gradually declines. Interestingly, energy consumption seems to decline in both countries around 7 years after the country's tighter regulatory standards were implemented.

In conclusion, similar to Ireland, tighter building regulations in conjunction with increased building activity are likely to explain the falling energy consumption levels in Latvia and Hungary over time (see Fig. 7). However the effects are lagged by around 7 years after the country's implementation of tighter building standards.

Preliminary Conclusion 6: Tighter regulations are most effective when accompanied by high construction activities in the residential sector.

\section{Conclusion and Policy Implications}

In this paper, we examine the effectiveness of environmental policies in reducing residential energy consumption. In contrast to former studies, we use an exploratory approach in order to find out which policies explain differences in energy efficiency between countries and to draw preliminary conclusions.

In our quantitative analysis we regress the mean annual energy use per dwelling in 29 European countries on a number of observable characteristics. We then plot country dummy coefficients in order to identify countries that exhibit inexplicably low or high energy consumption. Sweden and Finland stand out because of their low energy consumption, whereas Ireland can be found on the other end of the spectrum. We also plot residuals by country over time in order to spot improvements in energy efficiency. Latvia and Hungary display a falling time trend. We then analyze these countries’ policy environments qualitatively.

We find that building part regulations are an effective policy instrument for reducing the consumption of energy in residential buildings. However, the impact of regulatory standards for new buildings and major renovations becomes only visible over longer time periods, as for example in Sweden and Finland, unless the tightened regulation is accompanied by a building 
boom, as for example in Ireland, Latvia and Hungary. While regulations have markedly contributed to the reduction of overall energy consumption in Latvia, Hungary and Ireland, these three countries are still positioned in the lower half of our energy performance ranking, which, again, speaks to the longer time periods required for regulations to affect energy performance. In response, the EPBD 2018/844/EU aims at the acceleration of cost-effective renovations of existing buildings (EU, 2018) and many countries are incentivizing energy renovations through tax credits or direct subsidies (Friedrich, 2013).

Our results also point toward an additional policy instrument: carbon taxation. As regulatory standards as well as other factors (such as the performance and the share of district heating) are almost identical in the case of Sweden and Finland, another explanation is required in order to understand the relatively advanced performance of Sweden in comparison to Finland when it comes to energy consumption. The qualitative analysis and expert interviews suggest that this crucial difference can be found in high carbon taxation rates that have existed in Sweden. The decline in the energy consumption pattern over time is consistent with such an explanation as the increases in taxation coincide with the decline but cannot be explained by the timing of building code reforms. In this regard the scope of carbon taxation plays a crucial role for its effectiveness. A carbon tax of only $4.50 €$ per ton of $\mathrm{CO}_{2}$ as in Latvia or $30 €$ in Finland cannot show the far-reaching effects as observed in Sweden (with a carbon tax of $120 €$ per ton of $\mathrm{CO}_{2}$ ).

From our research, the following policy implications and preliminary conclusions can be derived, which should be validated in future studies:

1. Strict regulations are effective in lowering energy consumption.

2. Carbon and energy taxes are effective in improving energy efficiency.

3. The prevalence of relatively efficient district heat systems has caused lower energy use.

4. The effectiveness of carbon taxation is highly dependent on its scope. A tax of $30 €$ and a tax of $120 €$ per ton of $\mathrm{CO}_{2}$ cause markedly different reductions in energy consumption.

5. Stringent building regulations are only effective in the long run.

6. Tighter regulations are most effective when followed by high construction activities in the residential sector. 
There are certain limitations to our approach. While our qualitative analysis leads us to argue that carbon taxation can be an effective policy instrument for reducing energy consumption, quantitative efforts should validate this preliminary conclusion. As more and more countries introduce carbon taxes, more data for such an endeavor will be available in the near future. In this regard, Lin and $\mathrm{Li}$ (2011) have already provided a valuable first contribution by examining the impact of carbon taxation on overall $\mathrm{CO}_{2}$ emissions. Future studies should be careful to include the varying tax rates as our results indicate that the difference between a tax of $30 €$ and a tax of $120 €$ per ton of $\mathrm{CO}_{2}$ causes markedly different outcomes.

Furthermore, the use of the country specific effects as an energy policy indicator has two major limitations, one of which is the omitted variable bias. As above mentioned, the country dummies absorb the effects of omitted variables. Moreover, the country dummies could include cultural factors or habits in what concerns energy consumption. Further research should address these limitations.

Finally, while we cautiously suggest that both regulatory building standards as well as carbon taxation can be effective policy approaches for reducing energy consumption, we have not addressed the cost-benefit aspects of these policies. There are strong theoretic reasons to believe that a taxation scheme will cause market actors to discover the most cost-efficient means of lowering $\mathrm{CO}_{2}$ emissions.

However, since we used an exploratory analysis we were able to shed some light on energy policies which were earlier neglected due to homogenization by quantification of energy policies. Therefore, our analysis provides useful policy implications for further enhancement of energy efficiency policies in the European Union and elsewhere. 


\section{References}

Aroonruengsawat, A., Auffhammer, M., Sanstad, A.H., 2012.The Impact of State Level Building Codes on Residential Electricity Consumption. The Energy Journal, 33(1):31-52.

Ástmarsson, B., Jensen, P.A., Maslesa, E., 2013. Sustainable renovation of residential buildings and the landlord/tenant dilemma. Energy Policy, 63: 355-362.

Bavbek, G., 2016. CarbonTaxation Policy Case Studies. EDAM Energy and Climate Change Climate Action Paper Series 2016/4.

Bertoldi, P.; Mosconi, R. (2015). The Impact of energy efficiency policies on energy consumption in the EU Member States: A New Approach based on Energy Policy Indicators.

Bigano, A., Bosello, F., Marano, G., 2006. Energy Demand and Temperature: A Dynamic Panel Analysis. FEEM Working Paper No. 112.06.

Boverket - Swedish National Board of Housing, Building and Planning, 2008. Föreskrifter om ändring i verkets byggregler. Föreskrifter och allmänna råd, in: Boverkets Författningssamling, BFS 2008:20.

Bundesinstitut für Bau-, Stadt und Raumforschung, 1977. Wärmeschutzverordnung, nichtamtliche Lesefassung.

Bundesministerium für Umwelt, Naturschutz, Bau und Reaktorsicherheit, 2014. Energieeinsparverordnung, nichtamtliche Lesefassung.

Cameron, A.C., Trivedi, P.K., 2010. Microeconometrics Using Stata, Stata Press.

Centralas statistikas parvaldes datubazes [database]. https://www.csb.gov.lv/en/statistika/db (data retrieved 05.12.2017).

Conefrey , T., Fitz Gerald, J.D., Valeri, L.M., Tol, R.S.J., 2013. The impact of a carbon tax on economic growth and carbon dioxide emissions in Ireland. Journal of Environmental Planning and Management, 56(7): 934-952.

Department of the Environment, Ireland, 1991. Building Regulations 1991. Technical Guidance Document L Conservation of Fuel and Energy. Publ. by Stationery Office.

Department of the Environment, Ireland, 1997. Building Regulations 1997. Technical Guidance Document L Conservation of Fuel and Energy. Publ. by Stationery Office.

Department of the Environment, Ireland, 2002. Building Regulations 2002. Technical Guidance Document L Conservation of Fuel and Energy - Dwellings. Publ. by Stationery Office. 
Department of the Environment, Ireland, 2008. Building Regulations 2008. Technical Guidance Document L Conservation of Fuel and Energy - Dwellings. Publ. by Stationery Office.

Department of the Environment, Ireland, 2011. Building Regulations 2011. Technical Guidance Document L Conservation of Fuel and Energy - Dwellings. Publ. by Stationery Office.

EPA [United States Environmental Protection Agency], 2013. Location Efficiency and Housing Type - Boiling it Down to BTUs.Prepared by Jonathan Rose Companies.

EU, 2002. Directive (EU) 2002/91.

EU, 2010. Directive (EU) 2010/31.

EU, 2012. Directive (EU) 2012/27.

EU, 2018. DIRECTIVE (EU) 2018/844.

Euroheat and Power, 2013. Country by country statistics overview. https://www.euroheat.org/publications/country-by-country/ (accessed 01.02.2018).

EUBIA [European Biomass Industry Association], 2014, Biomass for electricity, heating and cooling, EUBIA Report.

European Commission, 2003. Energy Efficiency and Certification of Central Air Conditioners, Final Report.

European Commission. EU Building Observatory [database]. https://ec.europa.eu/energy/en/eubuildings (data retrieved 21.04.2017).

Eurostat, 2018. Energy Consumption in Households. https://ec.europa.eu/eurostat/statisticsexplained/index.php/Energy_consumption_in_households (accessed 19.12.2018).

Eurostat: European Statistics [database]. https://ec.europa.eu/eurostat/data/database (data retrieved 21.04.2017).

Feser, D., Runst, P., 2016. Energy efficiency consultants as change agents? Examining the reasons for EECs’ limited success. Energy Policy, 98:309-317.

Filippini, M., Hunt, L.C., Zoric, J., 2014. Impact of energy policy instruments on the the estimated level of underlying energy efficiency in the EU residential sector. Energy Policy, 69:73-81.

Friedrich, S., 2013. Energy Efficiency in Buildings in EU Countries. CESifo DICE Report, 11, 57-59. 
Gerarden, T.D., Newell, R.G., Stavins, R.N., 2015. Deconstructing the energy-efficiency gap: conceptual frameworks and evidence. American Economic Review, 105(5), 183-86.

Gerarden, T.D., Newell, R.G., Stavins, R.N., 2017. Assessing the energy-efficiency gap. Journal of Economic Literature, 55(4), 1486-1525.

Gillingham, K., Harding, M., Rapson, D., 2012. Split Incentives in Household Energy Consumption. Energy Journal 33(2), 37-62.

GOS [Government Offices of Sweden]: Sweden's Carbon Tax 2018. https://www.government.se/government-policy/taxes-and-tariffs/swedens-carbon-tax/ (accessed 08.10.2018).

IEA: International Energy Agency [database]. https://www.iea.org/statistics/ (data retrieved 05.06.2017).

Irish Energy Agency, 2016. Energy Efficiency in Ireland, 2016 Report.

Jakubcionis, M., Carlsson, J., 2017. Estimation of European Union residential sector space cooling potential, Energy Policy 101, 225-235.

Joelsson, A., Gustavsson, L., 2009. District heating and energy efficiency in detached houses of differing size and construction. Applied Energy, 86(2):126-134.

Levinson, A., 2014. California Energy Efficiency: Lessons for the Rest of the World, or Not? Journal of Economic Behavior and Organization 107 (PA). Elsevier B.V.: 269-89.

Levinson, A., 2016. How Much Energy Do Building Energy Codes Really Save? Evidence from California. American Economic Review 106 (10): 2867-94.

Lin, B., Li, X., 2011. The effect of carbon tax on per capita CO2 emissions; Energy Policy 39:5137-5146.

Lorek, S., Trotta, G., 2015. Consumers and Energy Efficiency - Country Report Finland. An inventory of policies, business and civil society initiatives, focusing on heating, hot water and the use of electricity. EUFORIE - European Futures for Energy Efficiency.

Maas, S., Waldman, D., Zürbes, A., Scheuern, J.-J., 2007. Wie viel Energie der Luxemburger wirklich verbraucht. Revue technique Luxembourgoise 4/2007.

Ó Broin , E., Nässén, J., Johnsson, F., 2015. Energy Efficiency Policies for Space Heating in EU countries: A Panel Data Analysis for the period 1990-2010. Applied Energy, 150: 211-223.

Odyssee-Mure [database]. http://www.odyssee-mure.eu/(data retrieved 10.06.2017). 
OECD, 2013. Effective Carbon Prices, OECD Publishing.

OTB, Research Institute for the Built Environment, 2010. Housing Statistics in the European Union 2010.

Ranson, M., Morris, L., Kats-Rubin, A., 2014. Climate Change and Space Heating Energy Demand: A Review of the Literature, working paper 14-07, US National Center for Environmental Economics.

Republic of Latvia, 2001. Cabinet Regulation No 495. Regulations Regarding Latvian Construction Standard LBN 002-01 Thermotechnics of Building Envelope.

Republic of Latvia, Ministry of Finance, 2007. Operational Programme "Infrastructure and Services” (3.5.2 Energy).

Schild, P.G., Klinski, M., Grini, C., 2010. Analyse og sammenlikning av krav til energieffektivitet i bygg i Norden og Europa, Prosjektrapport 55, SINTEF Byggforsk.

SEA [Swedish Energy Agency], 2017. Energy in Sweden 2017. www.energimyndigheten.se (accessed 01.12.2017).

Swedish Energy Agency, 2015. Energy in Sweden 2015, online: www.energimyndigheten.se (accessed 01.02.2018).

SEAI [Sustainable Energy Authority of Ireland], 2018. Energy in the residential sector, 2018 report.

Statistics Finland [database]. https://www.stat.fi/index_en.html (data retrieved 14.11.2017).

Statistics Finland, 2017. Energy prices [e-publication]. ISSN=1799-800X. 2nd Quarter 2017, Appendix Table 1. Energy taxes, precautionary stock fees and oil pollution fees (accessed 11.10.2017).

Statistics Sweden [database]. https://www.scb.se/en/ (data retrieved 23.11.2017).

Svenska Kyl \& Värmepump Föreningen [database]. https://skvp.se/hem (data retrieved 12.07.2017).

Vainio, T., Lindroos, T., Pursiheimo, E., Vesanen, T., Sipilä, K., Airaksinen, M., Rehunen, A., 2015. High-efficiency CHP, district heating and district cooling in Finland 2010-2025. Report for the Ministry of Employment and the Economy.

Werner, S., 2017. District heating and cooling in Sweden, Energy 126, 2017, 419-429. 
World Bank, 2015. State and Trends of Carbon Pricing.

https://www.worldbank.org/content/dam/Worldbank/document/Climate/State-and-TrendReport-2015.pdf (accessed 01.02.2018).

World Bank, 2018. Carbon Pricing Dashboard 2018.

https://carbonpricingdashboard.worldbank.org/

https://carbonpricingdashboard.worldbank.org/map_data (accessed 04.05.2018). 
Tables

Table 1

Descriptive statistics

\begin{tabular}{|c|c|c|c|c|c|c|}
\hline Variable & Obs & Mean & Std. Dev. & Min & Max & Data Source \\
\hline $\begin{array}{l}\text { Consumption } \\
\text { (in toe_dw) }\end{array}$ & 406 & 1.336 & 0.516 & 0.300 & 3.277 & Odyssee-Mure \\
\hline WAPI & 444 & $1,368.910$ & 606.238 & 229.616 & $3,334.713$ & $\begin{array}{l}\text { based on: Odyssee- } \\
\text { Mure, IEA, OECD, } \\
\text { Eurostat, Statista }\end{array}$ \\
\hline age & 434 & 39.280 & 2.344 & 32.400 & 45.600 & Eurostat \\
\hline HDD & 435 & $2,942.892$ & $1,221.309$ & 306.604 & $6,058.319$ & Odyssee-Mure \\
\hline latitude & 464 & 49.136 & 7.239 & 35.126 & 61.924 & CIA Fact Book \\
\hline longitude & 464 & 14.947 & 13.657 & -8.244 & 60.128 & CIA Fact Book \\
\hline floor area & 417 & 90.415 & 22.081 & 34.360 & 145.771 & Odyssee-Mure \\
\hline GDPpercapita & 435 & $29,430.31$ & $21,918.14$ & $1,609.28$ & $116,612.9$ & Eurostat \\
\hline $\begin{array}{ll}\text { home } & \text { ow- } \\
\text { nership } & \\
\end{array}$ & 358 & 75.861 & 10.545 & 51.600 & 97.600 & Eurostat \\
\hline $\begin{array}{l}\text { apartment } \\
\text { share }\end{array}$ & 365 & 38.009 & 16.860 & 2.500 & 69.700 & Eurostat \\
\hline share post80 & 464 & 31.749 & 10.808 & 2.030 & 74.230 & $\begin{array}{lr}\text { based on: } & \text { European } \\
\text { Commission, } & \text { Norway } \\
\text { Statistical } & \text { Offices, } \\
\text { Odyssee-Mure } & \end{array}$ \\
\hline
\end{tabular}


Table 2

Regression Results 1

\begin{tabular}{|c|c|c|}
\hline & $\begin{array}{c}\text { Model } 1 \\
\text { LSDV }\end{array}$ & $\begin{array}{c}\text { Model } 2 \\
\text { IV }\end{array}$ \\
\hline Log WAPI & $\begin{array}{c}-0.122^{* *} \\
(0.016)\end{array}$ & $\begin{array}{c}-0.194^{* *} \\
(0.011)\end{array}$ \\
\hline Log HDD & $\begin{array}{l}0.163^{*} \\
(0.084)\end{array}$ & $\begin{array}{l}0.161^{*} \\
(0.059)\end{array}$ \\
\hline longitude & $\begin{array}{c}0.0110^{* * *} \\
(0.001)\end{array}$ & $\begin{array}{c}0.0312^{* * *} \\
(0.000)\end{array}$ \\
\hline latitude & $\begin{array}{c}0.0388^{* *} \\
(0.015) \\
\end{array}$ & $\begin{array}{c}0.0101 * * \\
(0.035) \\
\end{array}$ \\
\hline age & $\begin{array}{l}-0.133 \\
(0.142)\end{array}$ & $\begin{array}{l}-0.147^{*} \\
(0.067)\end{array}$ \\
\hline age $^{2}$ & $\begin{array}{l}0.00145 \\
(0.198)\end{array}$ & $\begin{array}{c}0.00164 \\
(0.101)\end{array}$ \\
\hline floor area & $\begin{array}{c}0.0256^{* * *} \\
(0.003)\end{array}$ & $\begin{array}{c}0.0277^{* * *} \\
(0.000)\end{array}$ \\
\hline floor_area $^{2}$ & $\begin{array}{c}-0.000128^{* * *} \\
(0.003)\end{array}$ & $\begin{array}{c}-0.000139 * * * \\
(0.000)\end{array}$ \\
\hline GDPpercapita (x1,000) & $\begin{array}{l}0.00612 \\
(0.116)\end{array}$ & $\begin{array}{l}0.00482 \\
(0.184)\end{array}$ \\
\hline GDPpercapita $^{2}$ & $\begin{array}{c}-4.51 \mathrm{e}-11^{* *} \\
(0.044)\end{array}$ & $\begin{array}{c}-4.02 \mathrm{e}-11^{* *} \\
(0.049)\end{array}$ \\
\hline home ownership & $\begin{array}{l}0.00106 \\
(0.461)\end{array}$ & $\begin{array}{l}0.00140 \\
(0.288)\end{array}$ \\
\hline apartment share & $\begin{array}{c}-0.00768^{* * *} \\
(0.001)\end{array}$ & $\begin{array}{c}-0.00774^{* * * *} \\
(0.000)\end{array}$ \\
\hline share post 80 & $\begin{array}{c}-0.00298 \\
(0.109) \\
\end{array}$ & $\begin{array}{c}-0.00206 \\
(0.252) \\
\end{array}$ \\
\hline $\mathrm{N}$ & 276 & 275 \\
\hline $\mathrm{R}^{2}$ & 0.983 & 0.983 \\
\hline
\end{tabular}

${ }_{1}$ Country and time fixed effects are included in both models. P-values are displayed in parentheses. 
Table 3

Building part regulation across chosen countries (u-values) $)_{2}$

\begin{tabular}{|c|c|c|c|c|c|c|c|c|c|c|c|c|c|}
\hline \multirow[b]{2}{*}{ Year } & \multicolumn{3}{|c|}{ Finland } & \multicolumn{2}{|c|}{ Germany } & \multicolumn{2}{|c|}{ Sweden } & \multicolumn{3}{|c|}{ Latvia } & \multicolumn{3}{|c|}{ Hungary } \\
\hline & 1978 & 1985 & 2010 & 1977 & 2014 & 1978 & 2008 & $<1991$ & 1991 & 2003 & $<1991$ & 1991 & 2006 \\
\hline Wall & $0.29-0.35$ & 0.28 & 0.17 & $1.45-1.75$ & 0.28 & $\begin{array}{c}0.25- \\
0.30\end{array}$ & 0.18 & 1.1 & 0.36 & $0.25-0.3$ & 1.2 & 0.7 & 0.45 \\
\hline Roof & $0.23-0.29$ & 0.22 & 0.09 & 0.45 & 0.2 & $\begin{array}{c}0.17- \\
0.20\end{array}$ & 0.13 & 1.3 & 0.31 & $0.2-0.25$ & 0.9 & 0.4 & 0.25 \\
\hline Windows & $2.1-3.1$ & $2.1-3.1$ & 1.00 & $1.6-3.5$ & 1.3 & $1.0-2.0$ & 1.3 & 5.9 & 2.0 & 1.8 & - & 3.00 & 1.6 \\
\hline Ground Floor & $0.23-0.4$ & $0.22-0.36$ & 0.16 & 0.9 & 0.35 & $\begin{array}{c}0.17- \\
0.30\end{array}$ & 0.15 & & & 0.25 & - & 0.85 & 0.25 \\
\hline
\end{tabular}

${ }_{2}$ The table displays u-values: $\frac{W}{m^{2} K}$

Sources: $\quad$ Finland $\quad$ - Odyssee-Mure Policy Data Base

Germany － Wärmeschutzverordnung 1977, nichtamtliche Fassung S. 9-12; Energieeinsparverordnung 2014 nichtamtliche Fassung S. $41 f$.

Sweden - SBN 1975 Supplement 1 S. 17, BFS 2008:20 BBR 16 S. 10.

Latvia - Cabinet Regulation No 495 Adopted 27 November 2001, “Implementation of the EPBD in Latvia Status in November 2010” by Dzintars Grasmanis

Hungary $\quad$ - before 1991: ME-30-65; 1991: BS-04-140/2-79; BS-04-140 2-85; DIN-04-140-2; 2006: 7/2006. (V. 24.) TNM 
Table 4

Building part regulations (u-values) for existent and new buildings in Ireland 3

\begin{tabular}{|c|c|c|c|c|c|c|}
\hline \multicolumn{7}{|c|}{ New Buildings } \\
\hline Year & 1991 & 1997 & 2002 & 2007 & 2011 & 2017 \\
\hline Wall & $0.45-0.6$ & $0.45-0.6$ & 0.27 & 0.27 & 0.21 & 0.21 \\
\hline Roof & $0.25-0.35$ & $0.25-0.35$ & $0.16-0.22$ & $0.16-0.22$ & $0.16-0.2$ & $0.16-0.2$ \\
\hline Windows & -- & 3.30 & 2.2 & 2 & 1.60 & 1.60 \\
\hline $\begin{array}{l}\text { Ground } \\
\text { Floor }\end{array}$ & $0.45-0.6$ & 0.45 & 0.25 & 0.25 & 0.21 & 0.21 \\
\hline Source: & $\begin{array}{l}\text { BRTGDL }_{4} \text {, } \\
1991 \text {, p. } 8\end{array}$ & $\begin{array}{l}\text { BRTGDL, } \\
\text { 1997, p. } 8\end{array}$ & $\begin{array}{l}\text { BRTGDL, } \\
2002 \\
\text { (Reprint } \\
\text { 2005) , p. } 9 \\
\end{array}$ & $\begin{array}{l}\text { BRTGDL, } \\
2007 \\
\text { (Reprint } \\
\text { 2008), p.17 }\end{array}$ & $\begin{array}{l}\text { BRTGDL, } \\
\text { 2011, p.17 }\end{array}$ & $\begin{array}{l}\text { BRTGDL, } \\
\text { 2017, p.18 }\end{array}$ \\
\hline \multicolumn{7}{|c|}{ Existent Buildings / Renovation } \\
\hline Year & 1991 & 1997 & 2002 & 2007 & 2011 & 2017 \\
\hline Wall & 0.60 & $0.45-0.6$ & 0.6 & 0.27 & $0.35-0.55$ & $0.35-0.55$ \\
\hline Roof & $0.35-0.6$ & $0.35-0.6$ & 0.35 & $0.16-0.22$ & $0.16-0.25$ & $0.16-0.25$ \\
\hline Windows & -- & 3.30 & 2.2 & 2 & 1.6 & 1.6 \\
\hline $\begin{array}{l}\text { Ground } \\
\text { Floor }\end{array}$ & -- & -- & -- & 0.25 & 0.45 & 0,45 \\
\hline Source: & $\begin{array}{l}\text { BRTGDL, } \\
1991 \text {, p. } 8\end{array}$ & $\begin{array}{l}\text { BRTGDL, } \\
\text { 1997, p. } 8\end{array}$ & $\begin{array}{l}\text { BRTGDL, } \\
2002 \\
\text { (Reprint } \\
\text { 2005) , p.9 }\end{array}$ & $\begin{array}{l}\text { BRTGDL, } \\
2007 \\
\text { (Reprint } \\
\text { 2008), p. } 28 \\
\end{array}$ & $\begin{array}{l}\text { BRTGDL, } \\
\text { 2011, p. } 26\end{array}$ & $\begin{array}{l}\text { BRTGDL, } \\
\text { 2017, p. } 27\end{array}$ \\
\hline
\end{tabular}

${ }_{3}$ All values are $\mathrm{u}$-values. The unit is $\frac{W}{m^{2} K}$

${ }_{4}$ BRTGDL = Building Regulations Technical Guidance Document L 


\section{Appendix}

Appendix A - Additional figures

Fig. A1. Residuals after panel regression by country over time

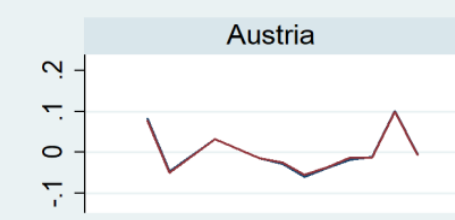

Croatia

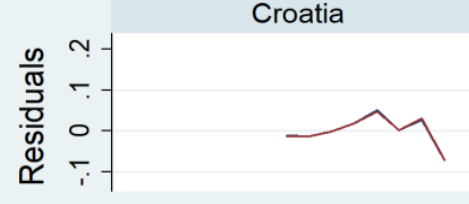

Denmark

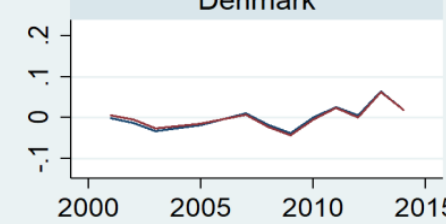

$2000-2005-2010 \quad 20152000$

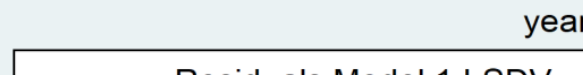

Residuals Model 1 LSDV

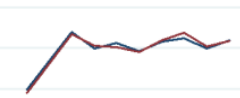

Estonia
Bulgaria

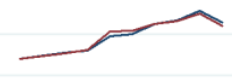

Czech Rep.

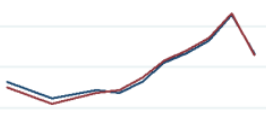

Finland

Graphs by country 
Fig. A1 (continued). Residuals after panel regression by country over time
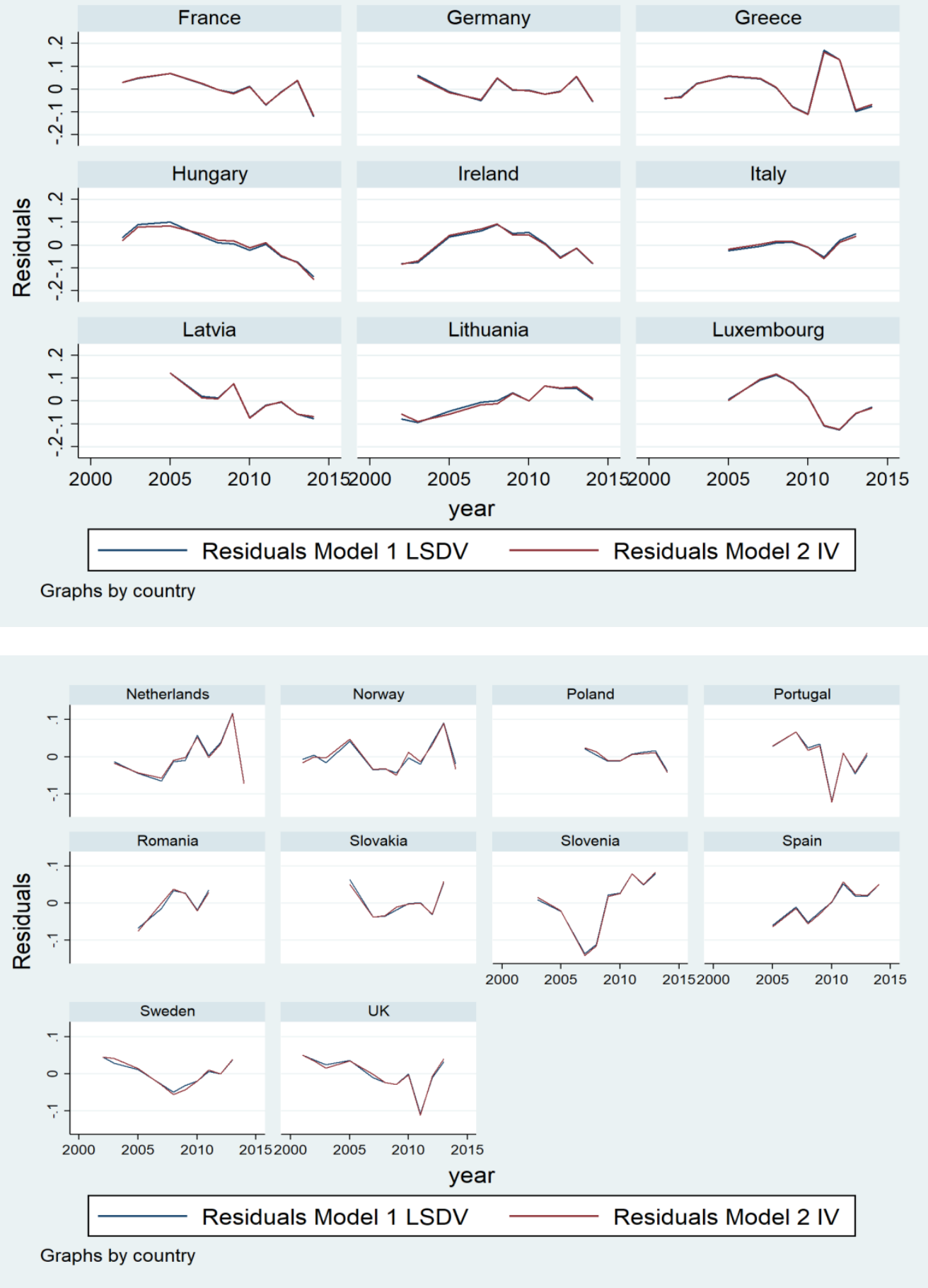
Fig. A2. Country fixed effects from robustness specification 2 and 3 (appendix C)

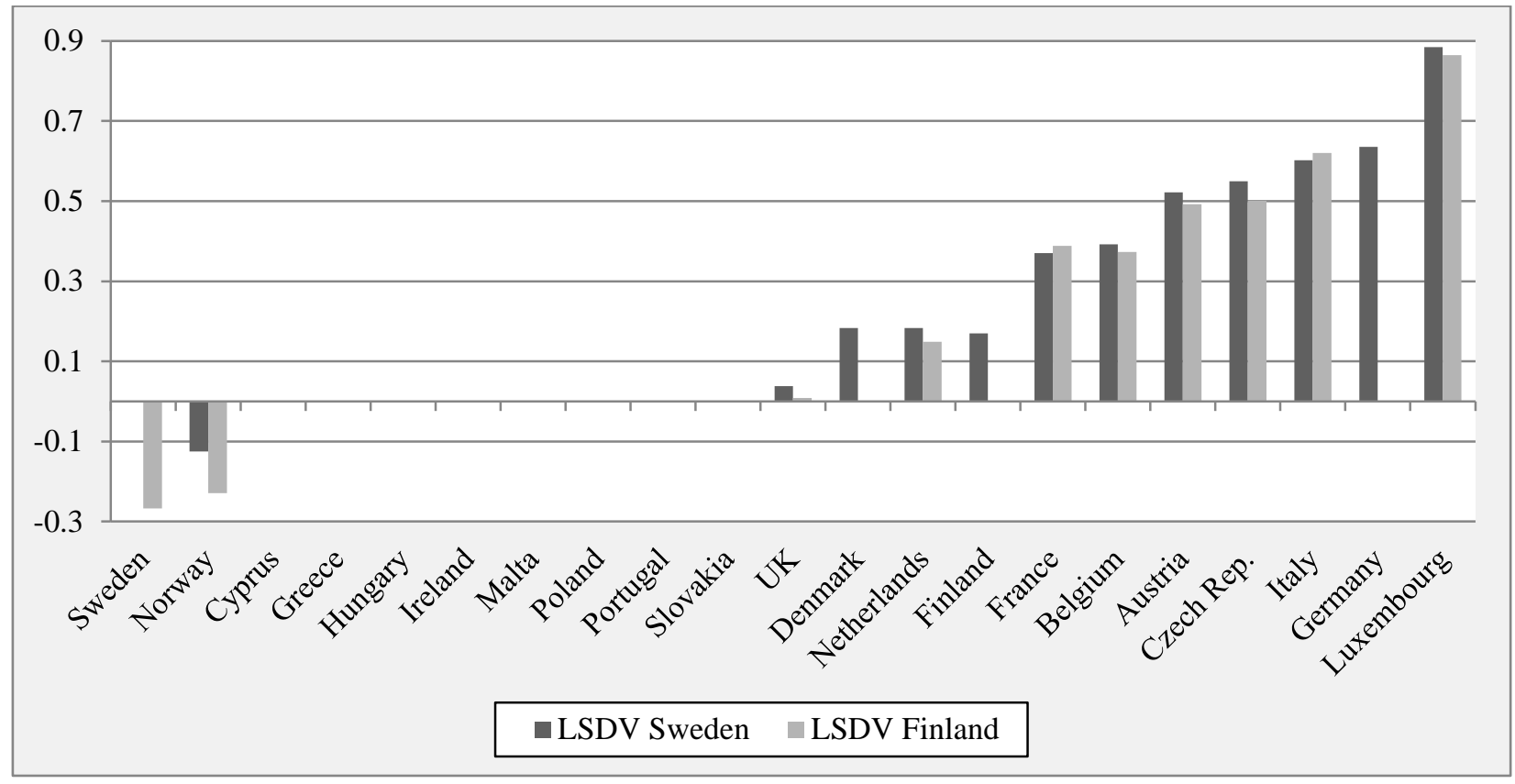


Appendix B - Overview on documents and interviewees

\begin{tabular}{ll}
\hline Country & Policy documents and interviews \\
\hline Sweden & Boverket (National Housing Board) building part regulation: www.boverket.de \\
& SBN 1975 Supplement 1, BFS 1993; BFS 2002:6; BFS 2008:20 \\
& Economist: 1 \\
& Swedish Energy Agency: 2 \\
& Boverket: 1 \\
& Swedish Green Building Council: 1 \\
& Building Regulations Technical Guidance Document L 1991, 1997, 2002 (Reprint \\
Ireland & 2005), 2007 (Reprint 2008), 2011 \\
& Economists: 1 \\
& Odyssee-Mure Policy Database \\
Finland & Ministry of the Environment: 1 \\
& Energy Authority: 1 \\
& ME-30-65; BS-04-140/2-79; BS-04-140 2-85; DIN-04-140-2; 7/2006. (V. 24.) \\
Hungary & Cabinet Regulation No 495 (Regulations Regarding Latvian Construction Stand- \\
Latvia & ard LBN 002-01 Thermotechnics of Building Envelopes \\
& Ministry of Finance Republic of Latvia 2007: Operational Programme “Infra- \\
& structure and Services” (3.5.2 Energy) \\
& Energy Efficiency Law \\
& Energy Law \\
& Centralas statistikas parvaldes datubazes \\
& Germany - Wärmeschutzverordnung (WSchVO) 1977; Energieeinsparverord- \\
& nung (EnEV) 2014 \\
& UK - National Audit Office, 2016. \\
&
\end{tabular}


Appendix C - Robustness Tests

\begin{tabular}{|c|c|c|c|c|c|}
\hline & $\begin{array}{l}\text { Price/Income } \\
\text { Interaction }\end{array}$ & $\begin{array}{l}\text { Sweden as } \\
\text { Reference }\end{array}$ & $\begin{array}{l}\text { Finland as } \\
\text { Reference }\end{array}$ & $\begin{array}{c}\text { ShareDistrict } \\
\text { Heating }\end{array}$ & $\begin{array}{l}\text { ShareDistrict } \\
\text { Heatingshort }\end{array}$ \\
\hline & (1) & (2) & (3) & (4) & (5) \\
\hline \multirow[t]{2}{*}{ Log WAPI } & $-0.115^{*}$ & $-0.120 *$ & $-0.120 *$ & $-0.122 * *$ & $-0.120 *$ \\
\hline & $(0.074)$ & $(0.063)$ & $(0.063)$ & $(0.017)$ & $(0.063)$ \\
\hline \multirow[t]{2}{*}{ Log HDD } & 0.126 & 0.155 & 0.155 & $0.163^{*}$ & 0.154 \\
\hline & $(0.213)$ & $(0.123)$ & $(0.123)$ & $(0.085)$ & $(0.126)$ \\
\hline \multirow[t]{2}{*}{ longitude } & 0.00939* & 0.00181 & 0.00500 & $0.0110^{* * *}$ & 0.00621 \\
\hline & $(0.052)$ & $(0.416)$ & $(0.138)$ & $(0.002)$ & $(0.110)$ \\
\hline \multirow[t]{2}{*}{ latitude } & $0.0696^{* * *}$ & $0.0247 * *$ & $0.0320 * *$ & $0.0390 * *$ & $0.0724 * * *$ \\
\hline & $(0.001)$ & $(0.045)$ & $(0.019)$ & $(0.016)$ & $(0.000)$ \\
\hline \multirow[t]{2}{*}{ age } & $-0.310 * * *$ & $-0.326 * * *$ & $-0.326 * * *$ & -0.133 & $-0.330 * * *$ \\
\hline & $(0.000)$ & $(0.000)$ & $(0.000)$ & $(0.145)$ & $(0.000)$ \\
\hline \multirow[t]{2}{*}{ age $^{2}$} & $0.00331^{* * *}$ & $0.00354^{* * *}$ & $0.00354^{* * *}$ & 0.00145 & $0.00358 * * *$ \\
\hline & $(0.001)$ & $(0.000)$ & $(0.000)$ & $(0.202)$ & $(0.000)$ \\
\hline \multirow[t]{2}{*}{ floor area } & 0.0140 & -0.00385 & -0.00385 & $0.0254^{* * *}$ & -0.00441 \\
\hline & $(0.497)$ & $(0.785)$ & $(0.785)$ & $(0.003)$ & $(0.758)$ \\
\hline \multirow[t]{2}{*}{ floor_area ${ }^{2}$} & -0.0000695 & 0.0000220 & 0.0000220 & $-0.000127^{* * *}$ & 0.0000254 \\
\hline & $(0.502)$ & $(0.745)$ & $(0.745)$ & $(0.003)$ & $(0.713)$ \\
\hline \multirow[t]{2}{*}{ GDPpercapita(x1000) } & 0.00468 & 0.00702 & 0.00702 & 0.00000612 & 0.00000689 \\
\hline & $(0.378)$ & $(0.117)$ & $(0.117)$ & $(0.116)$ & $(0.127)$ \\
\hline \multirow[t]{2}{*}{ GDPpercapita² } & $-4.29 e-11$ & $-5.25 \mathrm{e}-11^{* *}$ & $-5.25 e-11^{* *}$ & $-4.52 \mathrm{e}-11^{* *}$ & $-5.20 \mathrm{e}-11^{* *}$ \\
\hline & $(0.128)$ & $(0.036)$ & $(0.036)$ & $(0.044)$ & $(0.039)$ \\
\hline \multirow[t]{2}{*}{ home ownership } & $0.00284 *$ & $0.00288 * *$ & $0.00288^{* *}$ & 0.00105 & $0.00296 * *$ \\
\hline & $(0.058)$ & $(0.041)$ & $(0.041)$ & $(0.467)$ & $(0.042)$ \\
\hline \multirow[t]{2}{*}{ apartment share } & $-0.00842^{* * *}$ & $-0.00883 * * *$ & $-0.00883^{* * *}$ & $-0.00770 * * *$ & $-0.00891^{* * *}$ \\
\hline & $(0.005)$ & $(0.003)$ & $(0.003)$ & $(0.001)$ & $(0.002)$ \\
\hline \multirow[t]{2}{*}{ share post80 } & -0.00148 & -0.00212 & -0.00212 & -0.00300 & -0.00209 \\
\hline & $(0.462)$ & $(0.269)$ & $(0.269)$ & $(0.107)$ & $(0.275)$ \\
\hline \multirow[t]{2}{*}{ Finland } & $-1.062 * * *$ & $0.170^{* *}$ & & $-0.667 * * *$ & $-1.016 * * *$ \\
\hline & $(0.000)$ & $(0.029)$ & & $(0.001)$ & $(0.000)$ \\
\hline \multirow[t]{2}{*}{ Sweden } & $-1.417^{* * *}$ & & $-0.267 * *$ & $-1.132^{* * *}$ & $-1.246^{* * *}$ \\
\hline & $(0.000)$ & & $(0.029)$ & $(0.000)$ & $(0.000)$ \\
\hline \multirow[t]{2}{*}{ PricesxIncome } & $4.76 e-10$ & - & - & & \\
\hline & $(0.342)$ & - & - & & \\
\hline \multirow[t]{2}{*}{ ShareDistrictHeating } & - & - & - & -0.0400 & -0.150 \\
\hline & - & - & - & $(0.787)$ & $(0.521)$ \\
\hline \multirow[t]{2}{*}{ Constant } & 3.239 & $5.657 * * *$ & $5.272 * * *$ & -0.152 & $4.159^{* *}$ \\
\hline & $(0.115)$ & $(0.002)$ & $(0.005)$ & (0.936) & $(0.025)$ \\
\hline $\mathrm{N}$ & 196 & 196 & 196 & 276 & 206 \\
\hline $\mathrm{R}^{2}$ & 0.984 & 0.984 & 0.984 & 0.983 & 0.984 \\
\hline
\end{tabular}




\section{Robustness Tests (continued)}

\begin{tabular}{|c|c|c|c|c|}
\hline & Robust1 & Robust2 & Robust3 & Robust4 \\
\hline & (6) & (7) & (8) & (9) \\
\hline \multirow[t]{2}{*}{ Log WAPI } & $-0.140 * *$ & $-0.107 * * *$ & $-0.117 * * *$ & $-0.119 * * *$ \\
\hline & $(0.010)$ & $(0.008)$ & $(0.002)$ & $(0.001)$ \\
\hline \multirow[t]{2}{*}{ Log HDD } & 0.164 & $0.178^{*}$ & $0.000150^{* * *}$ & $0.276^{* * *}$ \\
\hline & $(0.102)$ & $(0.054)$ & $(0.000)$ & $(0.000)$ \\
\hline \multirow[t]{2}{*}{ longitude } & $0.00666^{* *}$ & 0.00381 & $0.00386 * *$ & - \\
\hline & $(0.038)$ & $(0.192)$ & $(0.034)$ & - \\
\hline \multirow[t]{2}{*}{ latitude } & 0.0202 & $0.0199 *$ & 0.00240 & - \\
\hline & $(0.147)$ & $(0.077)$ & $(0.660)$ & - \\
\hline \multirow[t]{2}{*}{ age } & $-0.181^{* *}$ & $-0.168^{* *}$ & - & - \\
\hline & $(0.040)$ & $(0.013)$ & - & - \\
\hline \multirow[t]{2}{*}{ age $^{2}$} & $0.00207 *$ & $0.00195^{* *}$ & - & - \\
\hline & $(0.053)$ & $(0.020)$ & - & - \\
\hline \multirow[t]{2}{*}{ floor area } & $0.0312 * * *$ & $0.0191 * * *$ & $0.0212 * * *$ & - \\
\hline & $(0.000)$ & $(0.005)$ & $(0.001)$ & - \\
\hline \multirow{2}{*}{ floor_area $^{2}$} & $-0.000158^{* * *}$ & $-0.0000993^{* * *}$ & $-0.000113^{* * *}$ & - \\
\hline & $(0.000)$ & $(0.002)$ & $(0.000)$ & - \\
\hline \multirow[t]{2}{*}{ GDPpercapita (x1000) } & 0.00607 & 0.00366 & $0.00564^{* *}$ & - \\
\hline & $(0.127)$ & $(0.201)$ & $(0.035)$ & - \\
\hline \multirow[t]{2}{*}{ GDPpercapita $^{2}$} & $-4.35 \mathrm{e}-11^{*}$ & $-2.72 \mathrm{e}-11$ & $-3.52 \mathrm{e}-11 * *$ & - \\
\hline & $(0.068)$ & $(0.114)$ & $(0.028)$ & - \\
\hline \multirow[t]{2}{*}{ home ownership } & 0.00200 & - & - & - \\
\hline & $(0.147)$ & - & - & - \\
\hline \multirow[t]{2}{*}{ apartment share } & - & - & - & - \\
\hline & - & - & - & - \\
\hline \multirow[t]{2}{*}{ share post80 } & - & - & - & - \\
\hline & - & - & - & - \\
\hline \multirow[t]{2}{*}{ Finland } & $-0.312^{* *}$ & $-0.232^{* *}$ & $-0.310^{* * *}$ & 0.0315 \\
\hline & $(0.037)$ & $(0.042)$ & $(0.000)$ & $(0.595)$ \\
\hline \multirow[t]{2}{*}{ Sweden } & $-0.651 * * *$ & $-0.473 * * *$ & $-0.552 * * *$ & $-0.0931^{*}$ \\
\hline & $(0.001)$ & $(0.006)$ & $(0.000)$ & $(0.084)$ \\
\hline \multirow[t]{2}{*}{ Constant } & 1067 & 1246 & -0.603 & -1058 \\
\hline & (0.577) & $(0.412)$ & $(0.243)$ & $(0.110)$ \\
\hline $\mathrm{N}$ & 288 & 343 & 343 & 361 \\
\hline $\mathrm{R}^{2}$ & 0.982 & 0.981 & 0.982 & 0.979 \\
\hline
\end{tabular}

Note: In model (2), (3) and (5) we drop all countries for which our weighted average price index contains less than $65 \%$ of the overall energy consumption. This applies to Bulgaria, Croatia, Estonia, Latvia, Lithuania, Romania, Slovenia and Spain 
Appendix D - Estimating Potential Bias due to Missing data

\begin{tabular}{|c|c|c|c|c|c|c|c|c|c|c|c|c|c|}
\hline \multirow[b]{2}{*}{ Country } & \multicolumn{6}{|c|}{$\begin{array}{l}\text { Average Share of Total Residential Energy Consumption } \\
\text { (in \%, 2000-2015) }\end{array}$} & \multicolumn{6}{|c|}{ Average Prices per toe (in \$, 2000-2015) } & \multirow[t]{2}{*}{$\begin{array}{c}\text { Residual } \\
\text { Share }^{\mathrm{a}}\end{array}$} \\
\hline & Oil & Gas & Coal & Electricity & $\begin{array}{c}\text { District } \\
\text { Heat }\end{array}$ & Biomass $^{\mathrm{b}}$ & Oil & Gas & Coal & Electricity & $\begin{array}{c}\text { District } \\
\text { Heat }\end{array}$ & Biomass $^{b}$ & \\
\hline Austria & $21.7 \%$ & $18.4 \%$ & $0.9 \%$ & $23.5 \%$ & $11.2 \%$ & $24.3 \%$ & 1092.69 & 1020.71 & 834.24 & 2409.27 & 531.42 & $\mathrm{X}$ & $24.3 \%$ \\
\hline Belgium & $35.7 \%$ & $40.1 \%$ & $1.5 \%$ & $19.3 \%$ & $0.0 \%$ & $3.5 \%$ & 929.75 & 1001.30 & 1016.35 & 2440.48 & $\mathrm{X}$ & $\mathrm{X}$ & $3.5 \%$ \\
\hline Bulgaria & $0.0 \%$ & $0.0 \%$ & $0.0 \%$ & $45.0 \%$ & $20.8 \%$ & $34.2 \%$ & $\mathrm{X}$ & $\mathrm{X}$ & $\mathrm{X}$ & 1133.91 & $\mathrm{X}$ & $\mathrm{X}$ & $55.0 \%$ \\
\hline Croatia & $10.0 \%$ & $19.9 \%$ & $0.0 \%$ & $21.0 \%$ & $5.6 \%$ & $43.4 \%$ & 972.78 & 626.87 & $\mathrm{X}$ & 1640.46 & 295.01 & $\mathrm{X}$ & $43.4 \%$ \\
\hline Cyprus & $42.9 \%$ & $0.0 \%$ & $0.0 \%$ & $41.2 \%$ & $0.0 \%$ & $15.9 \%$ & 1008.34 & $\mathrm{X}$ & $\mathrm{X}$ & 2434.49 & $\mathrm{X}$ & $\mathrm{X}$ & $15.9 \%$ \\
\hline Czech Rep. & $0.4 \%$ & $31.9 \%$ & $10.3 \%$ & $18.9 \%$ & $17.7 \%$ & $20.8 \%$ & 1040.74 & 738.31 & 264.75 & 1635.68 & 481.42 & $\mathrm{X}$ & $20.8 \%$ \\
\hline Denmark & $11.9 \%$ & $14.8 \%$ & $0.0 \%$ & $19.7 \%$ & $34.7 \%$ & $18.8 \%$ & 1735.27 & 1396.56 & 999.67 & 3740.41 & 887.45 & $\mathrm{X}$ & $18.8 \%$ \\
\hline Estonia & $0.7 \%$ & $3.8 \%$ & $0.1 \%$ & $16.6 \%$ & $39.4 \%$ & $39.4 \%$ & 1294.74 & 765.24 & $\mathrm{X}$ & 1562.62 & 358.39 & $\mathrm{X}$ & $39.5 \%$ \\
\hline Finland & $12.0 \%$ & $0.0 \%$ & $0.0 \%$ & $36.0 \%$ & $30.9 \%$ & $21.1 \%$ & 1144.13 & 187.65 & $\mathrm{X}$ & 1723.23 & 397.64 & $\mathrm{X}$ & $21.1 \%$ \\
\hline France & $19.4 \%$ & $31.1 \%$ & $0.3 \%$ & $29.3 \%$ & $3.8 \%$ & $16.1 \%$ & 1053.76 & 874.32 & 569.51 & 1779.01 & 553.59 & $\mathrm{X}$ & $16.1 \%$ \\
\hline Germany & $26.1 \%$ & $38.1 \%$ & $0.0 \%$ & $20.1 \%$ & $6.5 \%$ & $9.3 \%$ & 951.23 & 1023.20 & $\mathrm{X}$ & 3078.78 & 591.98 & $\mathrm{X}$ & $9.3 \%$ \\
\hline Greece & $46.7 \%$ & $3.4 \%$ & $0.0 \%$ & $30.7 \%$ & $0.9 \%$ & $18.3 \%$ & 1261.42 & 1098.33 & $\mathrm{X}$ & 1650.50 & $\mathrm{X}$ & $\mathrm{X}$ & $19.2 \%$ \\
\hline Hungary & $0.0 \%$ & $52.2 \%$ & $3.0 \%$ & $15.5 \%$ & $9.8 \%$ & $19.6 \%$ & $\mathrm{X}$ & 541.58 & 324.89 & 1793.82 & 383.68 & $\mathrm{X}$ & $19.6 \%$ \\
\hline Ireland & $37.1 \%$ & $20.5 \%$ & $18.0 \%$ & $23.6 \%$ & $0.0 \%$ & $0.8 \%$ & 1168.36 & 949.36 & 1005.32 & 2465.28 & 161.03 & $\mathrm{X}$ & $0.8 \%$ \\
\hline Italy & $14.4 \%$ & $47.5 \%$ & $0.0 \%$ & $20.1 \%$ & $1.0 \%$ & $16.9 \%$ & 1780.20 & 1145.09 & $\mathrm{X}$ & 2752.94 & 658.74 & $\mathrm{X}$ & $16.9 \%$ \\
\hline Latvia & $3.3 \%$ & $5.4 \%$ & $0.0 \%$ & $10.6 \%$ & $30.5 \%$ & $50.2 \%$ & 1271.21 & 641.42 & $\mathrm{X}$ & 1241.41 & 404.26 & $\mathrm{X}$ & $50.2 \%$ \\
\hline Lithuania & $0.0 \%$ & $9.4 \%$ & $0.0 \%$ & $14.9 \%$ & $36.3 \%$ & $39.3 \%$ & $\mathrm{X}$ & 656.29 & $\mathrm{X}$ & 1433.62 & 463.89 & $\mathrm{X}$ & $39.3 \%$ \\
\hline Luxembourg & $41.6 \%$ & $40.0 \%$ & $0.1 \%$ & $14.9 \%$ & $0.0 \%$ & $3.4 \%$ & 865.56 & 707.62 & 764.26 & 2116.78 & $\mathrm{X}$ & $\mathrm{X}$ & $3.4 \%$ \\
\hline Malta & $0.0 \%$ & $0.0 \%$ & $0.0 \%$ & $99.3 \%$ & $0.0 \%$ & $0.7 \%$ & $\mathrm{X}$ & $\mathrm{X}$ & $\mathrm{X}$ & 1672.92 & $\mathrm{X}$ & $\mathrm{X}$ & $0.7 \%$ \\
\hline Netherlands & $0.4 \%$ & $75.9 \%$ & $0.0 \%$ & $17.8 \%$ & $2.2 \%$ & $3.7 \%$ & 1278.06 & 1048.86 & $\mathrm{X}$ & 2572.16 & 534.10 & $\mathrm{X}$ & $3.7 \%$ \\
\hline Norway & $4.9 \%$ & $0.0 \%$ & $0.0 \%$ & $79.3 \%$ & $0.0 \%$ & $15.7 \%$ & 1513.82 & $\mathrm{X}$ & $\mathrm{X}$ & 1452.05 & $\mathrm{X}$ & $\mathrm{X}$ & $15.7 \%$ \\
\hline Poland & $4.4 \%$ & $16.4 \%$ & $31.8 \%$ & $11.4 \%$ & $23.0 \%$ & $13.0 \%$ & 1060.56 & 719.71 & 428.37 & 1679.85 & 310.94 & $\mathrm{X}$ & $13.0 \%$ \\
\hline Portugal & $21.3 \%$ & $7.5 \%$ & $0.0 \%$ & $37.0 \%$ & $0.0 \%$ & $34.1 \%$ & 1278.41 & 1184.75 & $\mathrm{X}$ & 2365.38 & $\mathrm{X}$ & $\mathrm{X}$ & $34.1 \%$ \\
\hline Romania & $0.0 \%$ & $30.1 \%$ & $0.0 \%$ & $11.3 \%$ & $18.3 \%$ & $40.3 \%$ & $\mathrm{X}$ & 490.18 & $\mathrm{X}$ & 1579.99 & 387.90 & $\mathrm{X}$ & $40.3 \%$ \\
\hline
\end{tabular}




\begin{tabular}{|c|c|c|c|c|c|c|c|c|c|c|c|c|c|}
\hline Slovakia & $0.1 \%$ & $56.9 \%$ & $0.0 \%$ & $18.2 \%$ & $23.4 \%$ & $1.3 \%$ & 450.37 & 642.84 & 311.89 & 1933.07 & 536.33 & $\mathrm{X}$ & $1.3 \%$ \\
\hline Slovenia & $26.8 \%$ & $7.9 \%$ & $0.0 \%$ & $22.3 \%$ & $7.9 \%$ & $35.1 \%$ & 1192.83 & 1149.84 & $\mathrm{X}$ & 1804.38 & 415.26 & $\mathrm{X}$ & $35.1 \%$ \\
\hline Spain & $24.4 \%$ & $21.8 \%$ & $0.0 \%$ & $37.9 \%$ & $0.0 \%$ & $16.0 \%$ & 1021.72 & $\mathrm{X}$ & $\mathrm{X}$ & 2319.23 & $\mathrm{X}$ & $\mathrm{X}$ & $37.8 \%$ \\
\hline Sweden & $6.4 \%$ & $0.5 \%$ & $0.0 \%$ & $48.3 \%$ & $31.2 \%$ & $13.6 \%$ & 1821.35 & 1916.58 & $\mathrm{X}$ & 2106.57 & 553.58 & $\mathrm{X}$ & $13.6 \%$ \\
\hline $\begin{array}{l}\text { United } \\
\text { Kingdom }\end{array}$ & $6.8 \%$ & $64.8 \%$ & $2.2 \%$ & $24.1 \%$ & $0.1 \%$ & $2.0 \%$ & \begin{tabular}{|l|l|}
897.48 \\
\end{tabular} & 765.06 & 901.59 & 2066.09 & 324.15 & $\mathrm{X}$ & $2.0 \%$ \\
\hline
\end{tabular}

Note: $\quad{ }^{a}$ Residual Share represents the share of the overall energy consumption that is unaccounted for in the Weighted Average Price Index.

${ }^{b}$ Data on the average share of biomass of a country's total energy consumption is drawn from the Odyssee-Mure Database which only provides data on residential wood

consumption. However, as biomass consumption in residential buildings is composed almost exclusively of wood (EUBIA, 2014) the two measures are almost identical. In the text, we use the term "biomass". 
Appendix E - Correlation Matrix

\begin{tabular}{|c|c|c|c|c|c|c|c|c|c|c|c|}
\hline & WAPI & share post 80 & floor area & $\begin{array}{l}\text { GDP per } \\
\text { capita }\end{array}$ & HDD & $\begin{array}{l}\text { home own- } \\
\text { ership }\end{array}$ & age & $\begin{array}{l}\text { apartment } \\
\text { share }\end{array}$ & latitude & longitude & $\begin{array}{c}\text { share district } \\
\text { heating }\end{array}$ \\
\hline WAPI & 1.000 & & & & & & & & & & \\
\hline share post 80 & 0.4808 & 1.000 & & & & & & & & & \\
\hline floor area & 0.6321 & 0.4832 & 1.000 & & & & & & & & \\
\hline GDP per capita & 0.3255 & 0.1259 & 0.6915 & 1.000 & & & & & & & \\
\hline HDD & -0.4170 & -0.3978 & -0.1977 & 0.2858 & 1.000 & & & & & & \\
\hline $\begin{array}{l}\text { home owner- } \\
\text { ship }\end{array}$ & -0.4250 & -0.0575 & -0.4339 & -0.4649 & 0.0425 & 1.000 & & & & & \\
\hline age & 0.0885 & -0.2903 & -0.3305 & -0.1348 & 0.0598 & -0.1853 & 1.000 & & & & \\
\hline apartment share & -0.1495 & -0.0755 & -0.5748 & -0.4681 & -0.0253 & 0.1454 & 0.4081 & 1.000 & & & \\
\hline latitude & -0.3868 & -0.4304 & -0.1000 & 0.3614 & 0.9139 & -0.0546 & -0.0340 & -0.1672 & 1.000 & & \\
\hline longitude & -0.1944 & -0.1620 & -0.2833 & -0.2458 & 0.3561 & 0.2124 & 0.1671 & 0.3342 & 0.1738 & 1.000 & \\
\hline $\begin{array}{l}\text { share district } \\
\text { heating }\end{array}$ & -0.4558 & -0.3990 & -0.5170 & -0.2902 & 0.5999 & 0.2407 & 0.1309 & 0.4260 & 0.5657 & 0.5874 & 1.000 \\
\hline
\end{tabular}




\section{Chapter III}

\section{Dosis Facit Effectum}

\section{Why the Scope of the Carbon Tax Matters - Evidence from the Swedish Residential Sector}

With Petrik Runst

Revise and resubmit obtained from:

Energy Economics; submitted in September 2019 


\title{
Dosis Facit Effectum
}

\section{Why the Scope of the Carbon Tax Matters - Evidence from the Swedish Residential Sector}

\author{
Petrik Runst $^{\mathrm{a}}$, Anita Thonipara ${ }^{\mathrm{b}^{1}}$ \\ ${ }^{a}$ Institute for Small Business Economics at the University of Göttingen, Heinrich-Düker-Weg 6, 37073 Göttingen, Germany \\ ${ }^{b}$ Institute for Small Business Economics at the University of Göttingen, Heinrich-Düker-Weg 6, 37073 Göttingen, Germany
}

\begin{abstract}
Sweden has gradually increased its carbon tax within the past 25 years and imposes the world's highest tax on carbon dioxide emissions today. This paper examines the impact of the Swedish carbon tax on residential carbon emissions. We perform Difference-in-Differences (DiD) regressions and Synthetic Control Methods (SCM) in order to evaluate the causal impact of carbon taxation on carbon emissions in the residential sector. Both methods provide evidence for a causal effect of the carbon tax augmentation in the early 2000s on residential carbon emissions. We find that the scope of the reduction of residential carbon emissions due to the carbon tax augmentation ranges between $200 \mathrm{~kg}$ (when compared to other countries with a carbon tax of more than 20 Euros implemented) and $800 \mathrm{~kg}$ of $\mathrm{CO}_{2}$ per capita per year (when compared to countries without a carbon tax). Hence, the evidence points towards the effectiveness of carbon taxation in reducing residential $\mathrm{CO}_{2}$ emissions and, thus, mitigating climate change.
\end{abstract}

Keywords: carbon tax, Sweden, residential building, $\mathrm{CO}_{2}$ emissions JEL codes: H23, K32, P18, Q58

\footnotetext{
${ }^{1}$ Corresponding author. Tel.: +49 5513917 4888. E-Mail address: anita.thonipara@wiwi.uni-goettingen.de
} 


\section{Introduction ${ }^{2}$}

As more and more countries are already affected by climate change, mitigating climate change represents one of the most urging problems on the international political agenda (United Nations 2018). The EU Roadmap to a low carbon economy aims for a reduction of residential greenhouse gas emissions reduction by 80-95\% below 1990 level by the year 2050 (European Commission 2011). In order to reach these targets, member states of the European Union should make use of energy policy instruments which are effective. Previous studies found regulatory measures to be effective in decreasing residential energy consumption (Filippini et al. 2014, Ó Broin et al. 2015) and, to a lesser extent, informational campaigns and financial incentives. However, EU member states should make use of energy policy instruments that are not only effective but also efficient. There are strong theoretic arguments for the cost efficiency of carbon taxation and there is some first evidence for its effectiveness as well (Thonipara et al. 2019; Lin and Li 2011; Bohlin 1998)

While the effects of regulatory measures have been analyzed comprehensively (i.e. Levinson 2016, Filippini et al. 2014, Ó Broin et al. 2015; Thonipara et al. 2019) there is a lack of studies focusing on the impact of a carbon taxation on residential carbon emissions. Previous studies have addressed carbon taxes' effects on overall country emissions (Lin and Li 2011), their distributional effects (Renner 2018; Chapa and Ortega 2017; Parry 2015; Jiang and Shao 2014; Gonzalez 2012; Bureau 2011) or focused on scenarios (Dong et al. 2017; Elliott and Fullerton 2014; Di Cosmo and Hyland 2013; Mori 2012).

However, the effects of a carbon tax on carbon emissions of the residential sector have not been considered yet. As of 2018, there are only around 20 countries with a national carbon tax scheme, most of which set a tax of less than 25 Euros per ton of $\mathrm{CO}_{2}$ (World Bank 2018, see Figure 1). In contrast, Sweden was one of the first countries that implemented a carbon tax in the early 1990s and imposes today the highest carbon tax in the world.

The tax was initially set at 26 Euros (converted) per ton of emitted $\mathrm{CO}_{2}$ (1991) after which it has been gradually increased to 120 Euros in 2018 (see figure 2). The largest upwards adjustment took place between 2001 and 2004 from around 40 Euros up to around 100 Euros per ton of $\mathrm{CO}_{2}$ (Sweden 2018). ${ }^{3}$ Simultaneously, carbon emissions in the residential sector have gradually decreased over the past 20 years (figure 2), with the steepest decrease between 1999 and 2006. The tax only appplies to sectors that are not subject to the European Emission Trad-

\footnotetext{
${ }^{2}$ We are grateful for comments from participants at the International IAEE Conference 2019 in Montreal. We thank Jan Magyar from the Innovation and Energy Agency for his patient email

${ }^{3}$ All prices according to a conversion rate of SEK 9.61 per Euro.
} 
ing Scheme (ETS) and there is a wide range of exemptions for the industrial sector. Energy consumers in the residential sector are subject to $100 \%$ of the tax, which makes it an ideal area for policy evaluation.

Figure 1: National Carbon Tax Rates (01.01.2019, in Euros)

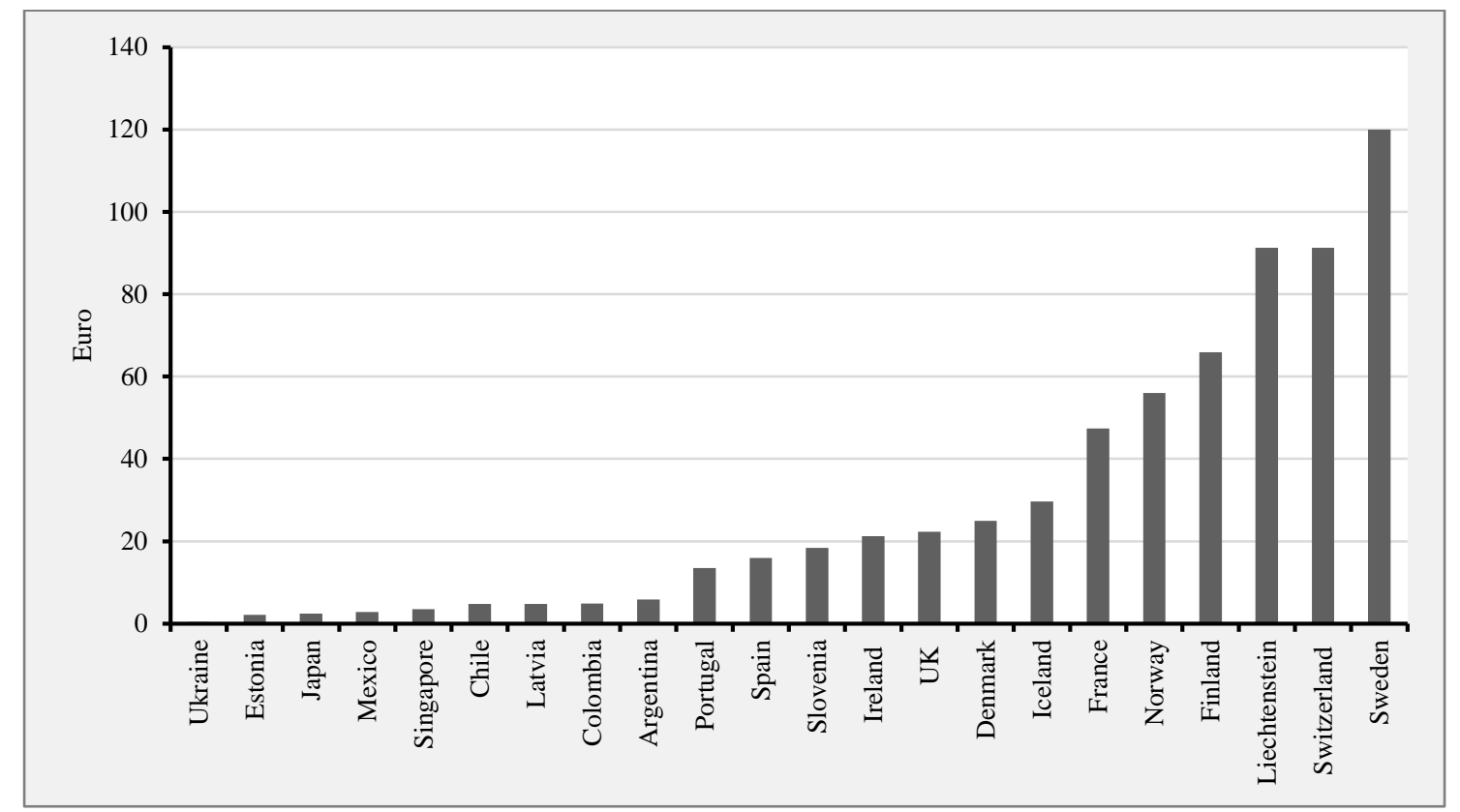

Source: own elaboration; data based on data by World Bank (2019)

To our knowledge, there are few evaluations of the Swedish carbon tax. Shmelev and Speck (2018) do not find a significant impact of the carbon tax on overall emissions but find other fuel specific taxes to be significantly effective. The authors, however, do not focus on residential buildings but on the industrial and transport sector instead, which are both subject to other taxes and a number of carbon tax exemptions. Another study examines the impact of energy related taxation on carbon emissions from the transportation sector by using Synthetic Control Methods (Andersson 2017). The author suggests that the taxes reduced annual emissions by 11\%. Similarly, Lin and Li use differences-in-differences regressions in order to estimate the carbon tax impact in five northern European countries (Lin and Li 2011). They do not find an impact of carbon taxation on $\mathrm{CO}_{2}$ emissions in Sweden. The authors speculate that the nonexistent impact is due to a number of exemptions, targeting various sectors of the economy. As there are only few studies on the effectiveness of carbon taxation in general and fewer studies still on the Swedish taxation scheme in particular, we concentrate the effects the carbon tax had on the residential sector, which is subject to the full impact of the carbon tax and has not been examined in the literature. 
Figure 2: Development of $\mathrm{CO}_{2}$ Emissions by Swedish Residential Buildings (in million tons of $\mathrm{CO}_{2}$, right hand axis) and Development of Swedish Carbon Tax rate (in SEK/ton $\mathrm{CO}_{2}$, left hand axis)

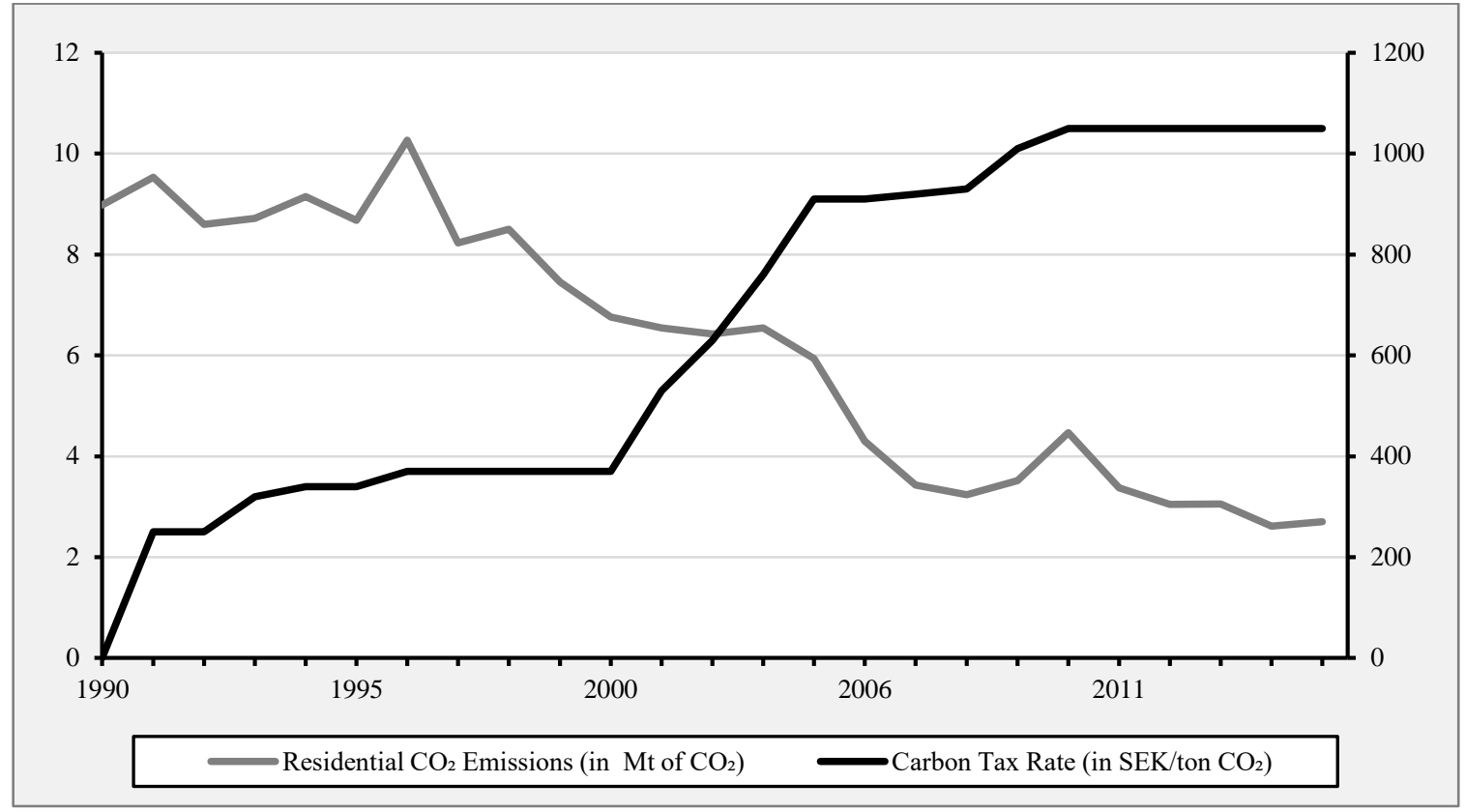

Sources: Odyssee-Mure Database; Hammar and Åkerfeldt 2012

We use European country-level panel data for the years 1990-2016 and apply Difference in Differences (DiD) and Synthetic Control Methods (SCM) in order to study the severe increase in Swedish carbon tax rates around the year 2001 on residential $\mathrm{CO}_{2}$ emissions. The results provide evidence for a moderate to strong and robust negative causal effect of the carbon tax augmentation on residential carbon emissions, in the range between 200 and $800 \mathrm{~kg}$ of $\mathrm{CO}_{2}$ per capita per year. Using different control groups comprised of various countries with different carbon taxes or no carbon tax at all, we find the scope of the carbon tax to be decisive for the tax's effectiveness - dosis facit effectum [the dose makes the effect].

As the implementation of or the increase in the carbon tax is currently being widely debated at all political levels, and as the residential sector accounts for around 25\% of European $\mathrm{CO}_{2}$ emissions, the current study fills an important gap in the literature.

This paper is structured as follows: chapter two will give an overview over the methods and data used for this paper. Results are presented in chapter three and discussed in chapter four. We draw a conclusion in chapter five. 


\section{Data and Methods}

\subsection{Data and Methods}

European country-level panel data is used:17 countries of the European Union (namely Austria, Belgium, Czech Republic, Denmark, Finland, France, Germany, Greece, Ireland, Italy, Luxembourg, Netherlands, Poland, Slovakia, Spain, Sweden and UK) as well as Norway and Switzerland. Other countries of the European Union could not be considered due to a lack of data. Furthermore our panel data set is limited to the years 1990-2016 due to data availability. $^{4}$

Residential carbon emissions per capita by country and year serve as our main dependent variable. We control for the prices of electricity and oil, in addition to GDP per capita and Heating Degree Days (HDD) as a measure of country and year specific climatic conditions. Table A1 in the appendix lists all variables and their sources. Table B1 displays descriptive statistics.

The main challenge of our data is posed by the fact that there is no clean pre-period without treatment. The carbon tax in Sweden exists since 1991 and has been repeatedly increased ever since. However, after slight increases before 1996, and a plateau between 1996 and 2000, the carbon tax was drastically increased within a three year period. We treat the period before 2001 as the pre-treatment period and the period after 2000 as the post-treatment period. As we implicitly disregard the existing low treatment intensity in the pre-period, we underestimate the overall tax effect because a proportion of the difference in carbon emissions between Sweden and other countries in the period 1991-2000 is likely due to the low treatment intensity in the 1990s. However, our methods (erroneously) attribute the overall difference as an unexplained pre-treatment country fixed effect. Our results should therefore be regarded as lower bound estimates.

Comprehensive data on the carbon tax rates of all sample countries and years does not exist. However, the total tax per unit of oil can be used as a proxy indicator of the overall tax burden on fossil fuels in a country. Figure 3 plots the total tax per unit of oil in USD (PPP) for all countries over time. Besides Sweden, other countries exhibit high levels of energy taxation and increases after the year 2000, namely Denmark, Italy, Greece and the Netherlands. We will therefore employ additional specifications in our analysis below, where we omit these countries from the sample. Similarly, the countries that have implemented a carbon tax higher than 20 Euros per ton of $\mathrm{CO}_{2}$ will be omitted from the control group in some specifications. In

\footnotetext{
${ }^{4}$ Information on data sources, variables, variable names and units used see table A1 and B1 in the appendix.
} 
one of the SCM samples however, the control group consists of other countries that have some form of carbon tax in order to examine whether the higher Swedish tax has an impact on emissions vis-à-vis these lower intensity treatments.

Figure 3: Total Tax per 1000 liters of oil (in USD/unit using PPP per 1000 liter light fuel oil)

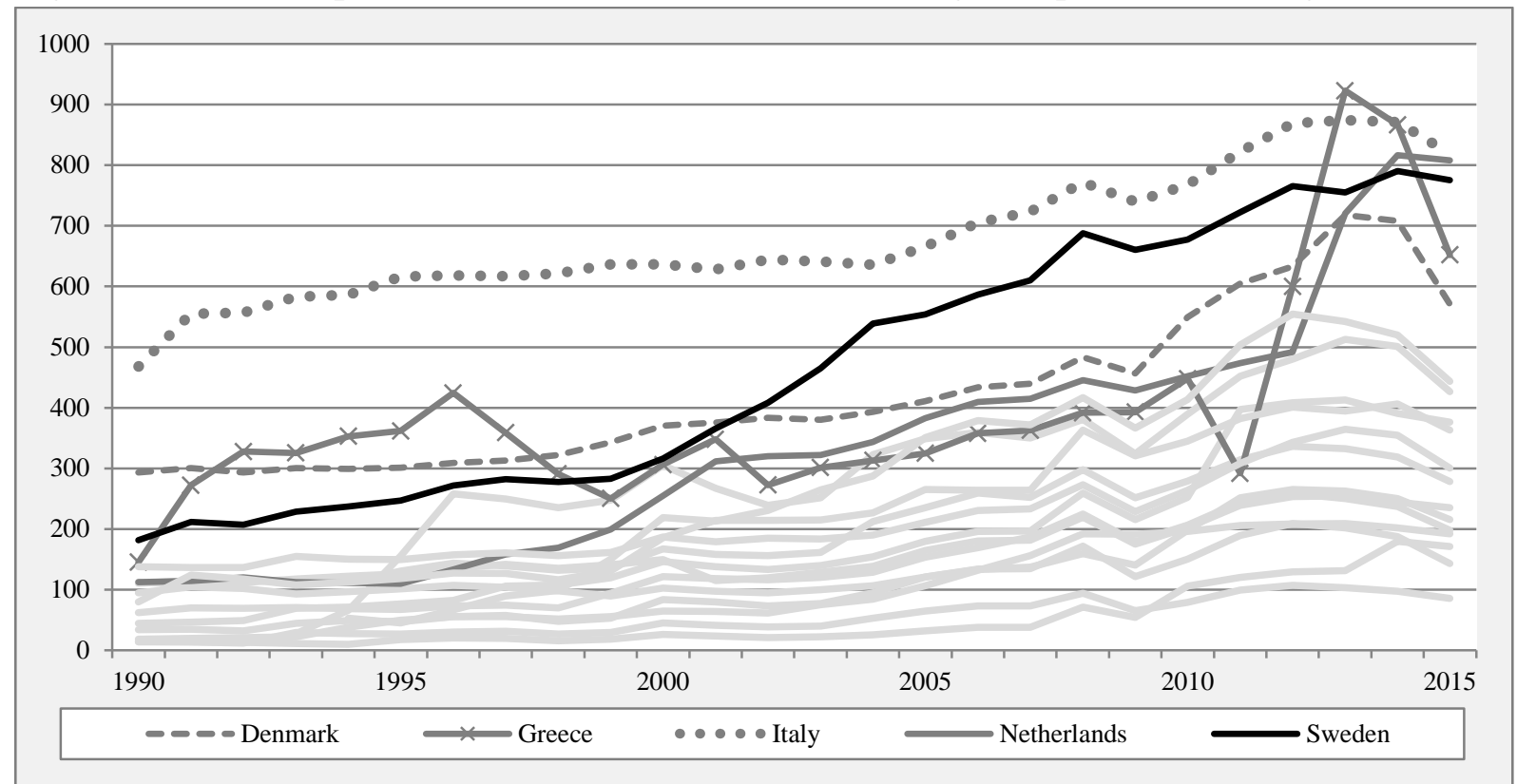

Source: Authors own elaboration; data kindly provided by the OECD

\subsection{Methods}

We run DiD regressions in which residential $\mathrm{CO}_{2}$ emissions (in tons of $\mathrm{CO}_{2}$, by country and year) serve as the dependent variable. We include a dummy variable (dSweden) which equals 1 if the country is Sweden and 0 in the case of the control group. Instead of using a single pre- and post-period, we interact the treatment group dummy variable (dSweden) with each year $\left(d Y e a r_{t}\right)$. In addition, vector $\mathrm{X}$ contains further control variables, namely Heating Degree Days, GDP per capita as well as GDP per capita squared. The model takes the following form:

$$
\frac{\mathrm{CO}_{2}}{\text { capita }_{i t}}=\alpha+\beta_{1} d S w e d e n_{i}+\bar{\beta}_{2} d Y_{\text {ear }}+\beta_{3}\left(d B_{i} * d \operatorname{Year}_{t}\right)+\sigma \bar{X}_{i t}+\varepsilon_{i t}
$$

$\beta_{1}$ Captures the differences between the treatment and control groups prior to the policy, whereas $\beta_{2}$ captures the factors that would change per capita $\mathrm{CO}_{2}$ emissions over time, even in 
the absence of the policy intervention. Finally, $\beta_{3}$ captures the treatment effect for each individual year. Thus, it measures the effect of the policy intervention.

We use several different sub-samples. First, the overall sample of all European countries is used, except Luxembourg for which we do not have sufficient data. Thus, the first sample containing all countries will underestimate the true effect since some control group countries also received treatment, albeit on a much lower scale. Secondly, we drop countries that showed exceptionally high energy taxes after the year 2000 (Italy, Denmark, the Netherlands and Greece) from the sample (sample 2). Finally, we drop all countries from the sample which have a carbon tax of more than 20 Euros per ton (Switzerland, Finland, Norway, UK and Ireland) and the four countries with exceptionally high energy taxes in order to get a control group which is not tainted by treatment.

Difference-in-Differences (DiD) Regressions are widely used for evaluating policies. However, in the particular case of the Swedish carbon tax DiD methods cannot be used without qualification. Firstly, using 2001 -the year of the carbon tax increase- as the intervention year means having no clean pre-treatment period, as a lower tax rate existed throughout the 1990s. Secondly, the year of the carbon tax implementation 1991 can also not be used as the intervention year due to a lack of panel data for the years before 1991. Thirdly, DiD-methods can only be used if treatment and comparison groups would have developed equally without the treatment. The DiD results can only be interpreted as causal if the parallel regression assumption is valid and if there are no confounding factors which selectively affected the treatment or control group after the year in which treatment begins. We can check the parallel regression assumption by plotting the development of $\mathrm{CO}_{2} /$ capita for the treatment and the control group over time. In addition, none of the yearly interaction terms before treatment should be significant in order to infer a causal relationship. Of course, the parallel regression assumption is already jeopardized by the fact that there have been frequent tax increases in Sweden during the 1990s. As this renders clean identification of the treatment effect impossible, we expect that in the pre-treatment years, some interaction terms coefficients may be significant but with a low negative effect. The effects after the intervention year should, in comparison, be highly significant and show much stronger effects.

As the three above mentioned limitations lead to doubts about the validity of robust conclusions on causality drawn based on the DiD Model. We thus, run a Synthetic Control Model which is, for the particular case of the Swedish carbon tax, a more suitable and reliable estimator. 


\subsection{Synthetic Control Model}

In order to measure the effects the carbon tax increase had on residential carbon emissions, we would need to know how the carbon emissions of the Swedish residential sector would have developed in the absence of the carbon tax increase. We, therefore, employ Synthetic Control Methods.. SCM uses several donor countries as comparison units and constructs a synthetic control group out of a weighted average of these donor pool countries (on SCM estimation see Abadie, Diamond, and Hainmueller 2015; Abadie and Hainmueller 2014; Abadie, Diamond, and Hainmueller 2010). That means in order to estimate the effect of the carbon tax increase in Sweden, we need a synthetic Swedish residential sector as a control group which closely tracks the Swedish residential sector carbon emissions prior to the tax increase, which then serves as the unobserved counterfactual. While the parallel regression assumption in the DiD regression model is likely violated from the outset, the SCM suffers less from the fact that low intensity treatment existed in Sweden before 2001. SCM factors in these differences when generating a control group that matches the development of the Swedish residential $\mathrm{CO}_{2}$ emission per capita in the pre-treatment period.

As in the DiD approach we use data on residential $\mathrm{CO}_{2}$ emissions per capita for 19 European countries for the time period 1990-2016. As explanatory variables, country and year specific prices on oil and electricity, GDP per capita as well as HDD (in order to control for weather fluctuations) are included. Additionally, we control for the country and year specific share of district heating in a supplementary robustness check. We do not use prices for gas, and biomass due to missing data for certain countries and years. Furthermore, we use different lags of our dependent variable.

There are three samples, and for each sample 6 specifications. Sample 1 includes all countries (except for Luxembourg due to a lack of data). Sample 2 includes all countries without carbon tax or with a carbon tax lower than 20 Euros. Besides this, countries with relatively high overall energy taxes after the year 2000 (see figure 2, Italy, Greece, Netherlands) are dropped. Sample 3 includes all countries with a carbon tax higher than 20 Euros (Switzerland, Finland, Norway, Denmark, UK, and Ireland). By using sample 3, we therefore compare low level treatment intensity countries (in the donor pool) with a high level treatment country (Sweden). We expect that in sample 1 and 2, the difference between the synthetic Sweden and real Sweden is smaller because countries in the donor pool are also experiencing low level treatment intensities, thereby underestimating the true reform effect. The difference between 
groups and, thus, the effect size of the carbon tax increase should be higher in the case in which we use countries without carbon taxation in the control group.

Table 1: Samples SCM

\begin{tabular}{|c|c|c|}
\hline $\begin{array}{c}\text { Sample } \mathbf{1} \\
\text { All countries }\end{array}$ & $\begin{array}{c}\text { Sample } 2 \\
\text { No / low carbon tax countries }\end{array}$ & $\begin{array}{c}\text { Sample } 3 \\
\text { Carbon tax countries }\end{array}$ \\
\hline $\begin{array}{l}\text { All below mentioned countries in- } \\
\text { cluded }\end{array}$ & $\begin{array}{l}\text { Countries without carbon tax or with } \\
\text { low carbon tax (less than } 20 \text { Euros } \\
\text { per ton of } \mathrm{CO}_{2} \text { ), } \\
\text { countries with exceptionally high } \\
\text { energy tax are dropped }\end{array}$ & $\begin{array}{l}\text { All countries with a carbon tax higher } \\
\text { than } 20 \text { Euros }\end{array}$ \\
\hline $\begin{array}{l}\text { Austria, Belgium, Czech Republic, } \\
\text { Denmark, Finland, France, Germany, } \\
\text { Greece, Ireland, Italy, Netherlands, } \\
\text { Norway, Poland, Slovakia, Spain, } \\
\text { Sweden, Switzerland, UK }\end{array}$ & $\begin{array}{l}\text { Austria, Belgium, Czech Republic, } \\
\text { France, Germany, Poland, Slovakia, } \\
\text { Spain, Sweden }\end{array}$ & $\begin{array}{l}\text { Denmark, Finland, Ireland, Norway, } \\
\text { Sweden, Switzerland, UK }\end{array}$ \\
\hline
\end{tabular}

For each sample, we run several specifications. In specification 1 we use three lags of $\mathrm{CO}_{2}$ emissions (1990, 1994, and 2000). In specification 2 we use the years 1998, 1999, and 2000 as lags. Finally, we include all lags in specification 3. Specification 4 includes the lags from specification 1 and adds HDD, GDPpC, oil prices, and electricity prices as control variables. In order to determine which specification has achieved a minimization of the pre-treatment gap between treatment group and synthetic control group we compare the root mean squared prediction error (RMSPE). In addition, specifications that do not minimize the pre-treatment differences in the dependent variable cannot be used for further analysis. However, the five specifications seem to achieve a good pre-treatment fit. A list of variables used for each specification can be found in table 2 .

Table 2: Specifications SCM

\begin{tabular}{|c|c|c|c|c|}
\hline & 1 & 2 & 3 & 4 \\
\hline Lags & 1990, 1994, 2000 & 1998, 1999, 2000 & All lags & 1990, 1994, 2000 \\
\hline HDD & & & & Yes \\
\hline GDPpC & & & & Yes \\
\hline Price oil & & & & Yes \\
\hline Price electricity & & & & Yes \\
\hline
\end{tabular}

In order to select predictor weights, we use a fully nested optimization method which yields more precise estimates according to Mcclelland and Gault (2017).

The model takes the following form:

$$
\sum_{m=1}^{k} v_{m}\left(X_{1 m}-X_{0 m} W\right)^{2}
$$


Vector X1 represents the characteristics of the treated unit, namely the Swedish residential sector, in the period before the treatment; m represents the respective comparison country. Vector X0 captures the characteristics of the compare,son units which are multiplied by the vector of weights $(\mathrm{W})$ of the control countries. Thus, $\left(X_{1 m}-X_{0 m} W\right)$ captures the difference between the treated unit and the comparison units. $v_{m}$ is the weight for each comparison country. In the case of the synthetic control $\mathrm{W}^{*}, v_{m}$ is chosen such that the difference $\left(X_{1 m}-\right.$ $\left.X_{0 m} W\right)$ is minimized meaning that it best resembles the original Swedish residential sector before the year 2001.

\section{Results}

\subsection{Differences-in-Differences Regression}

Table 3 displays the results of the three DiD specifications. In all three regressions, there is a suggestion of a negative relationship between carbon taxation and carbon emissions. The interaction terms of the Sweden dummy variable and the year dummy is insignificant before the year 2001, except in 1995, in which case the effect size is small (81 to $112 \mathrm{~kg}$ of $\mathrm{CO}_{2}$ per capita), and in specification (1) and (2) for the year 1997 with an effect size of around $112 \mathrm{~kg}$ of $\mathrm{CO}_{2}$ per capita. After the year 2000, the interaction terms are generally significant and effect sizes are negative and sizable, ranging from reductions of $200 \mathrm{~kg}$ to $460 \mathrm{~kg}$ per capita and year. Effect sizes become generally larger over time, although one must be careful when interpreting coefficients in later years. The farther we move away from the initial treatment date the more likely it is that confounding factors exert an influence. In specification (1) and (2) the coefficients of the interaction terms are negative and significant for all post-treatment years. In specification (3), six out of nine post-treatment interaction term coefficients are significant and negative, the other three ones being negative and almost but not quite significant at the $10 \%$ level (p-value 0.1 ). In addition, and as expected, interaction term coefficients are larger in specification 3, when we include only non-tax countries in the control group.

Summarizing, we can say that some evidence exists that points toward a remarkable negative effect of carbon taxation on carbon emissions in the residential sector. However, the parallel trends assumption is partially violated. Thus, we should refrain from drawing causal conclusion. Yet, the results hint toward an effect which we analyze further by applying SCM. 
Table 3: Difference-in-Differences Regression

\begin{tabular}{|c|c|c|c|}
\hline & (1) & (2) & (3) \\
\hline & All countries & $\begin{array}{c}\text { High tax countries } \\
\text { dropped }\end{array}$ & Only non-tax countries \\
\hline treatment*1995 & $-0.0819 * * *$ & $-0.0855 * * *$ & $-0.1124 * * *$ \\
\hline treatment*1996 & -0.0539 & -0.0022 & 0.0400 \\
\hline treatment*1997 & $-0.1282 * * *$ & $-0.1117^{* * *}$ & -0.1545 \\
\hline treatment*1998 & 0.0252 & 0.0000 & -0.0682 \\
\hline treatment*1999 & -0.0701 & -0.0461 & -0.0000 \\
\hline treatment*2000 & -0.0095 & 0.0258 & -0.1058 \\
\hline treatment*2001 & $-0.2381 * *$ & $-0.2247 * * *$ & $-0.3318 *$ \\
\hline treatment*2002 & $-0.2239 * *$ & $-0.2144^{* * *}$ & $-0.3142 * *$ \\
\hline treatment*2003 & $-0.2593 *$ & $-0.2383 * *$ & -0.3086 \\
\hline treatment*2004 & $-0.2455^{*}$ & $-0.2144 * *$ & -0.3188 \\
\hline treatment*2005 & $-0.3028 * *$ & $-0.2768 * * *$ & $-0.4083^{*}$ \\
\hline treatment*2006 & $-0.3714^{* * *}$ & $-0.3391 * * *$ & $-0.4295 *$ \\
\hline treatment*2007 & $-0.3798 * * *$ & $-0.3646 * * *$ & $-0.4588^{*}$ \\
\hline treatment*2008 & $-0.3013 *$ & $-0.2665 * * *$ & -0.3932 \\
\hline treatment*2009 & $-0.3104^{* *}$ & $-0.2781^{* * *}$ & $-0.3832 * *$ \\
\hline HDD & 0.0003 & $0.0004 * * *$ & 0.0003 \\
\hline GDP per capita & 0.0000 & 0.0000 & 0.0000 \\
\hline GDP per capita squared & 0.0000 & 0.0000 & 0.0000 \\
\hline Constant & 0.7129 & 0.6267 & 0.0521 \\
\hline \multicolumn{4}{|l|}{ Additional control } \\
\hline Year dummy variables & yes & yes & yes \\
\hline Sweden dummy variable & yes & yes & yes \\
\hline Observations & 288 & 224 & 176 \\
\hline
\end{tabular}

$p$-values indicated as stars: ${ }^{*} p<0.10,{ }^{* *} p<0.05,{ }^{* * *} p<0.01$ 


\subsection{Synthetic Control Method}

Figure 4 plots the differences between Sweden and its synthetic counterpart for sample 1 (all countries) and the four specifications (as described in the methods section) for which RMSPE values are small and quite similar (0.05; 0.04; 0.03; 0.04). In all five specifications the minimization of pre-treatment differences of the outcome variable was successful, providing evidence for a negative causal relationship of carbon taxation and residential carbon emissions. The effect sizes range from 300 to $400 \mathrm{~kg}$ of carbon emissions per capita and year. After the year 2012, we see that the gap between Sweden and synthetic Sweden shrinks. We interpret this development as further evidence in favor of the hypothesized relationship between taxation and emission. Many countries have only recently begun to introduce carbon taxation, such as Switzerland (2008), Ireland (2010), the UK (2013) and France (2014) and thereby decreased the difference in the treatment intensity between Sweden and all other countries.

The country weights chosen to construct the synthetic residential sector consist mainly of Norway (between 65\% and 74\%) and to a smaller part of Poland (6\%-20\%) and Denmark ( 13\%). Furthermore, Italy (10.7\%) is used in specification 4, the UK (9\%) in specification 3. A detailed list of all country weights can be found in the appendix Table C1.

Figure 4: Synthetic Control Method (sample 1, all countries)

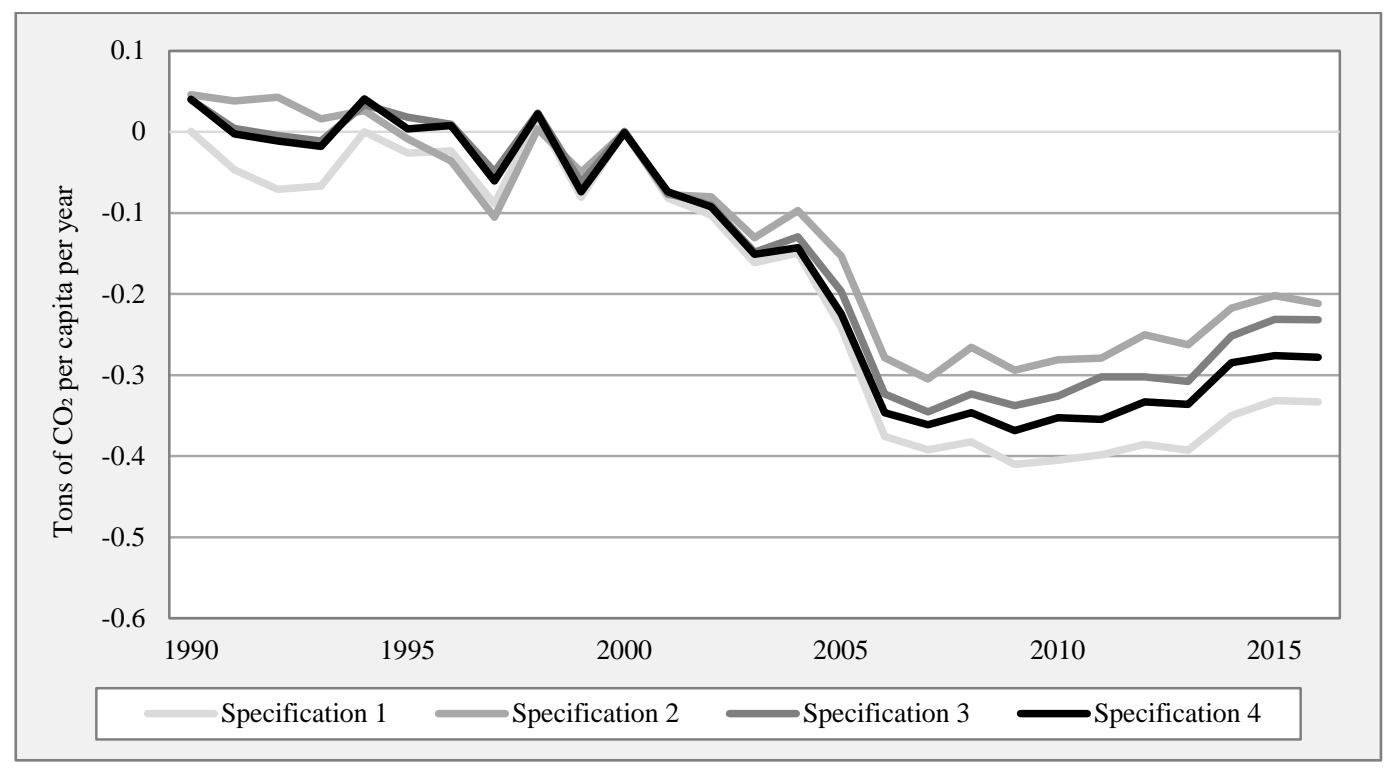

Notes: The lines display the difference in the dependent variable (residential $\mathrm{CO}_{2} /$ capita per country and year) between Sweden and its synthetically generated counterpart. The five different lines represent five different model specifications (as summarized in table 2). 
Figure 5 plots the differences between Sweden and its synthetic counterpart for sample 2 (only countries with low carbon taxes and without high overall energy taxation). Again, all four specifications achieve a good pre-treatment fit. The graph provides evidence for a treatment effect after the year 2000. As we have dropped countries that have either imposed carbon taxes or high energy taxation levels, we expect the treatment effect to be stronger using this sample. Indeed, the peak treatment effect for specification 4 is close to $800 \mathrm{~kg}$ of carbon dioxide emissions per year (for the year 2007). In the creation of a synthetic Sweden, France and Spain serve as primary input countries. Poland plays a smaller role in specifications 1 and 3. A detailed list of all country weights can be found in the appendix Table C2.

Figure 5: Synthetic Control Method (sample 2, countries with no carbon tax or carbon tax lower than 20 Euros and no major tax increases)

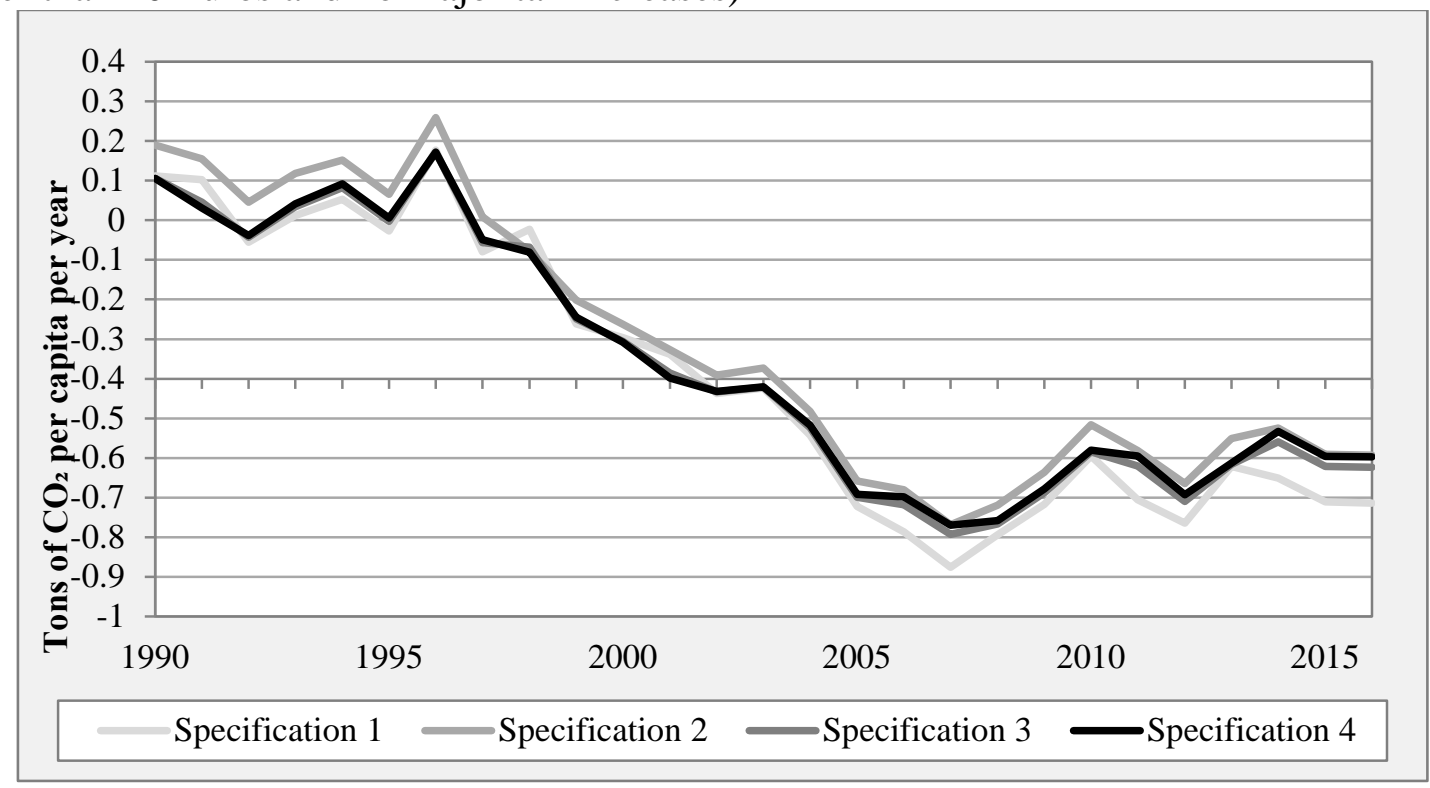

Notes: The lines display the difference in the dependent variable (residential $\mathrm{CO}_{2} /$ capita per country and year) between Sweden and its synthetically generated counterpart. The four different lines represent four different model specifications (as summarized in table 2).

Finally, the SCM results for sample 3 consisting of countries already imposing a carbon tax higher than 20 Euros per ton of $\mathrm{CO}_{2}$, are plotted in figure 6. Again, the impact of the relatively high tax increase in Sweden after the year 2000 affects carbon dioxide emissions negatively. We only include countries with (lower intensity) carbon taxation schemes and the effect sizes are therefore underestimated because only the difference in carbon taxation between Sweden and donor countries is being considered as treatment. Effect sizes range from 200 to $350 \mathrm{~kg}$ of carbon emissions per capita and year (for the years 2005 to 2010) after which the effect sizes start shrinking. As we have stated above, this is caused by donor pool countries 
imposing new carbon taxation schemes or increasing taxation rates. In this sample Norway makes up the greatest part of the synthetic control (around 71\%) followed by Denmark (1520\%). A detailed list of all country weights can be found in the appendix Table C3.

Figure 6: Synthetic Control Method (sample 3, countries with carbon tax higher than 20 Euros per ton of $\mathrm{CO}_{2}$ )

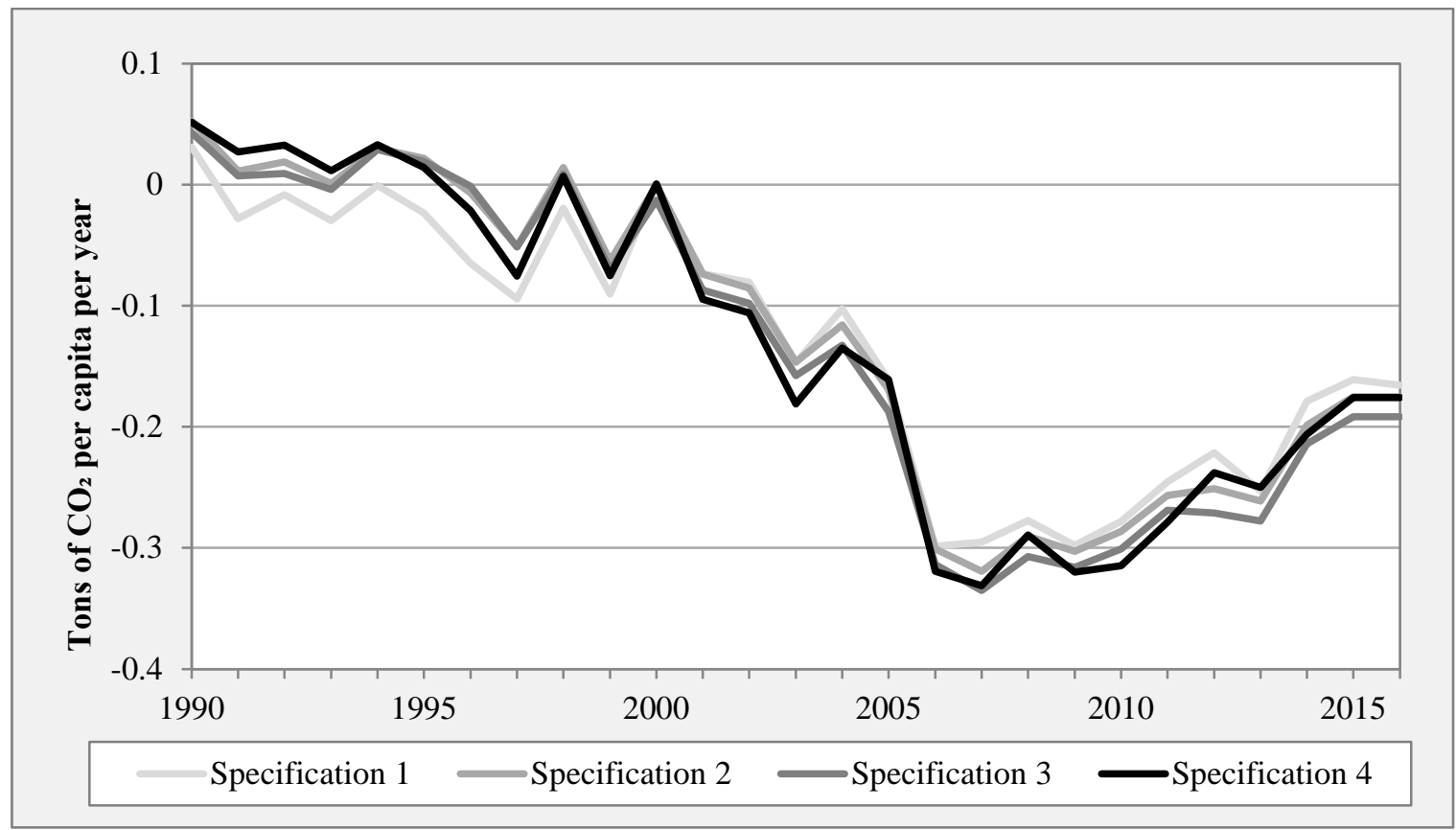

Notes: The lines display the difference in the dependent variable (residential $\mathrm{CO}_{2} /$ capita per country and year) between Sweden and its synthetically generated counterpart. The five different lines represent five different model specifications (as summarized in table 2).

\section{Robustness Checks}

It can be objected that, under certain conditions, district heating systems emit less carbon than single-building heating systems. We discuss this point in more detail in the discussion section. We, therefore, run additional SCMs, using specification 4 and including the variable 'district heat', which measures the ratio of district heat to all heat sources. Figure 7 plots the results for all three samples. Comparing the results of the SCM including the share of district heating with the results of specification 4 we do not find considerably different results (less than $50 \mathrm{~kg}$ of $\mathrm{CO}_{2} /$ capita). We can thus reject the argument of district heating being the driver of carbon emissions reductions. 
Figure 7: Synthetic Control Results with additional explanatory variable 'district heat' (sample 1, 2, and 3; specification 4)

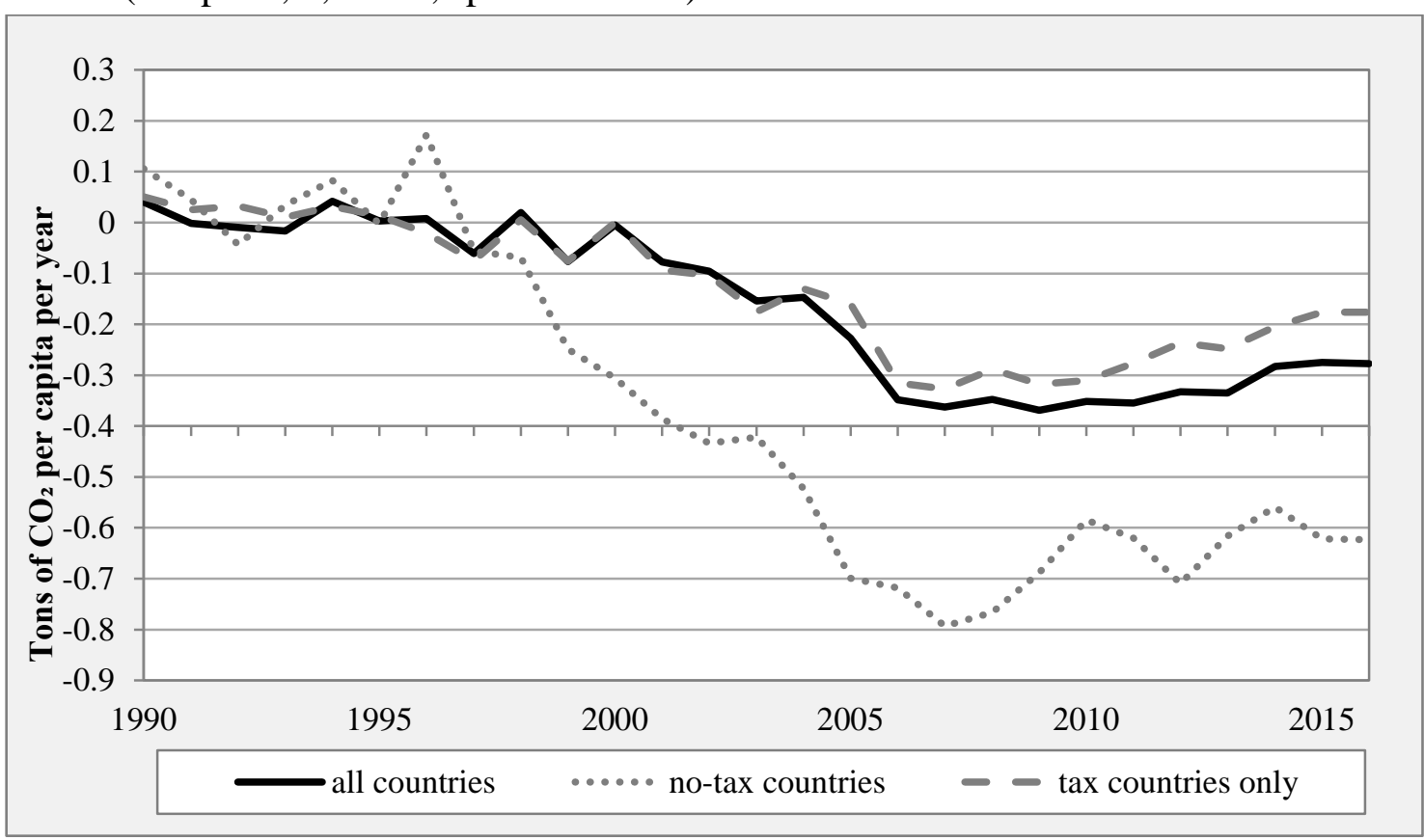

Notes: The lines display the difference in the dependent variable (residential $\mathrm{CO}_{2} /$ capita per country and year) between Sweden and it's synthetically generated counterpart.

We further run several country and in time placebo tests in order to check on the robustness of our results presented in chapter 3.2.

Figure 8 plots the results of a placebo test for sample 1 based on sample specification 4 . Each line represents a separate Synthetic Control Model. We cycle through the list of all sample countries, pretending each to be the treatment country. Figure 7 plots the resulting differences in the outcome variable between each treatment country and its synthetic counterpart. We omit countries for which the minimization of pre-treatment differences did not work - in this case Norway. There are only two countries for which a considerable treatment effect can be found - Sweden (solid black line) and Slovakia (dashed line). We further ran the same placebo test, adding the share of district heating variable. The placebo test shows the same results as can be seen in figure A1 in the appendix. 
Figure 8: Placebo Test (sample 1, all countries)

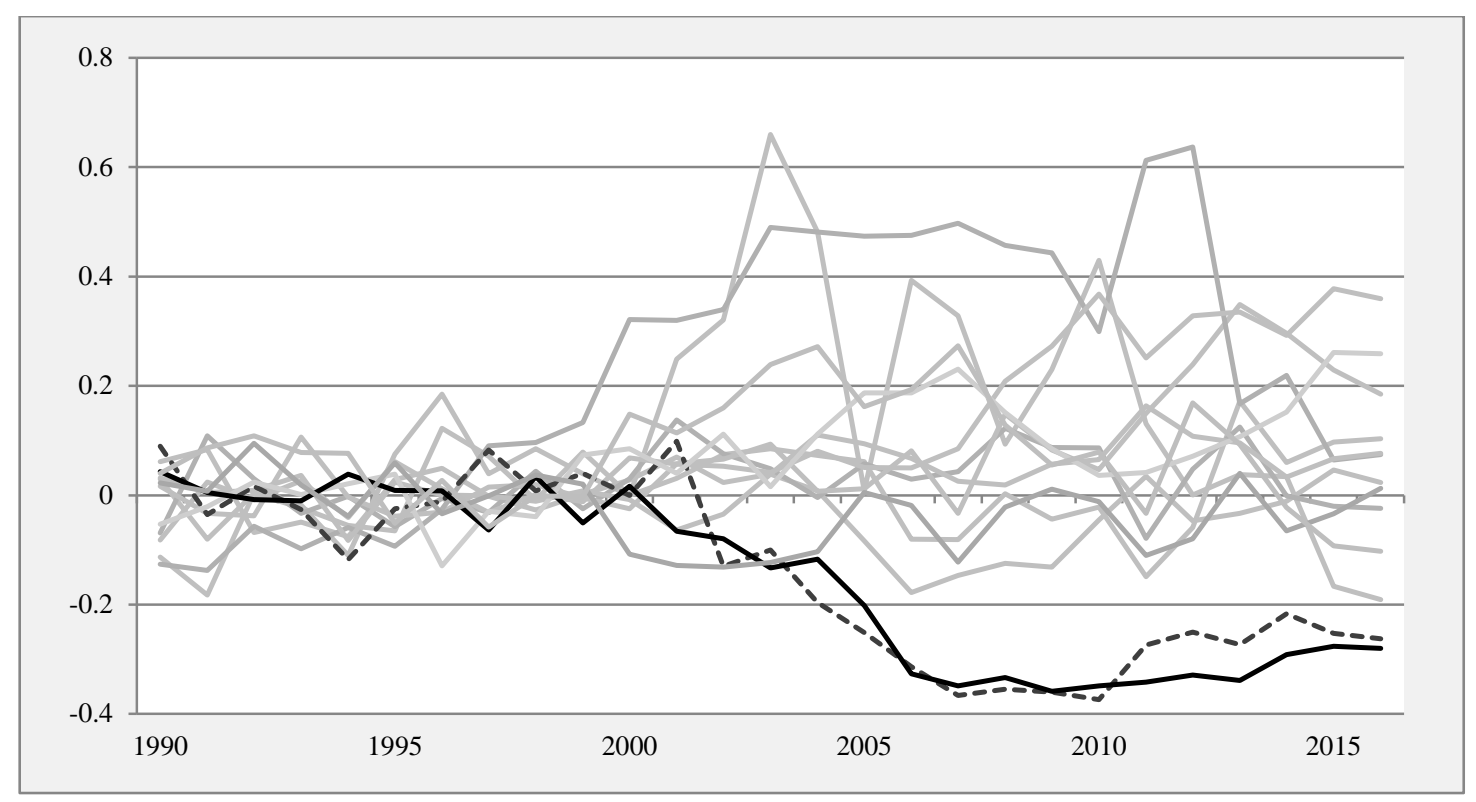

Notes: Each placebo tests (each line) treats one country as the treatment country, regardless of whether treatment was actually received or not. Each line displays the difference in the dependent variable (residential $\mathrm{CO}_{2}$ / capita per country and year) between the treatment country and its synthetically generated control group. Sweden is represented by the solid black line. The dashed line represents Slovakia.

Figure 9 plots the placebo tests for sample 2. Again, apart from Sweden, only Slovakia seems to have undergone some form of treatment around the year 2001. The case of Slovakia requires further analysis. In section 4, we will provide an explanation for the decline in carbon emission in the Slovakian residential sector. In particular, there is evidence for an increase in prices and taxation levels for gas after the year 2000, as well as an expansion of nuclear energy generation. Spain had to be omitted from the graph because its pre-treatment RMSPE value is much higher than for all other countries. Adding the share of district heating as a control variable leads to similar results. However, as figure A2 in the appendix shows the effect sizes are even slightly larger in Sweden. Instead of $800 \mathrm{~kg}$ reduction in the peak year 2007 we find a reduction of $900 \mathrm{~kg}$ in the year 2007 after having controlled for the share of district heating.

The placebo tests for sample 3 (figure 10) show that the country with the strongest effect size is indeed, Sweden (solid black line). There are only few lines here because the number of countries with carbon taxation is small. Denmark was dropped as the pre-treatment minimization of carbon emission levels was not successful. Placebo tests including the share of district heating are shown in figure A3 in the appendix. The effects sizes remain the same even when controlling for the share of district heating. 
Figure 9: Placebo Test (sample 2, countries with no or low carbon tax and low energy tax)

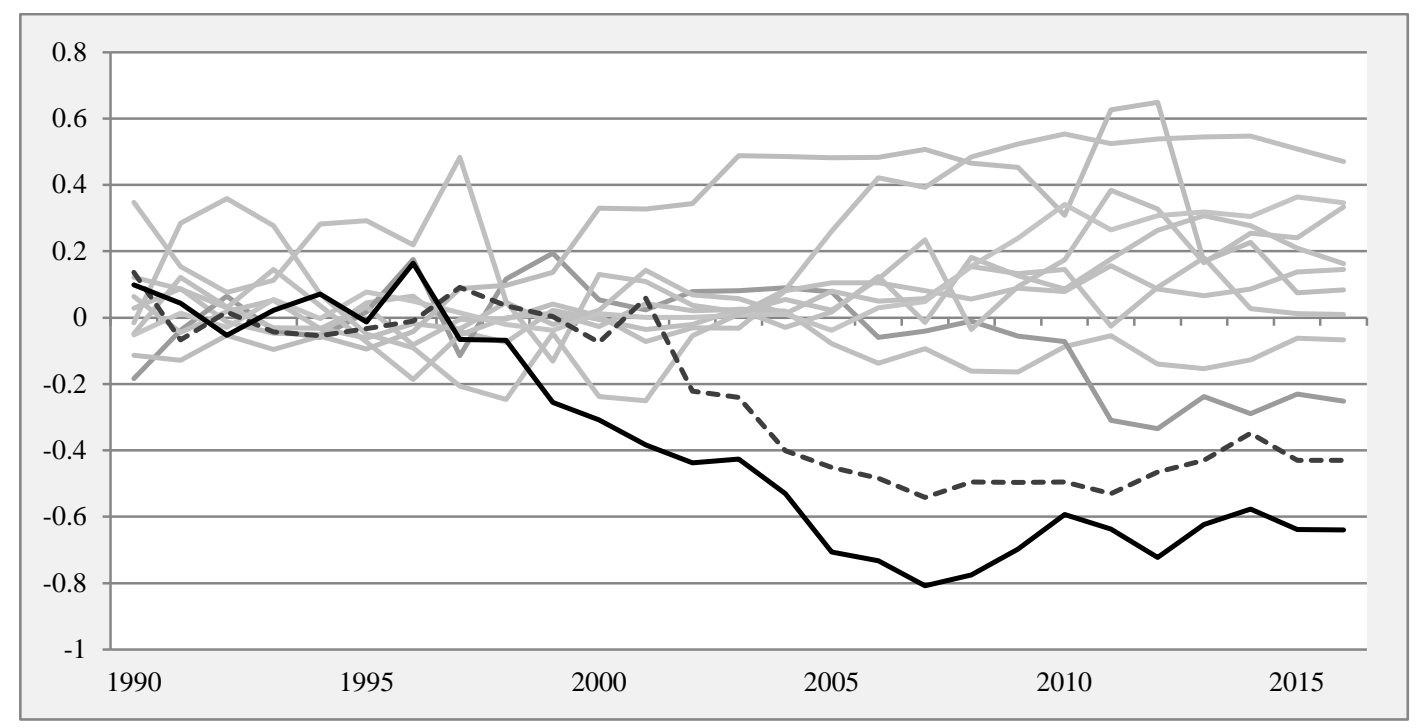

Notes: Each placebo tests (each line) treats one country as the treatment country, regardless of whether treatment was actually received or not. Each line displays the difference in the dependent variable (residential $\mathrm{CO}_{2} /$ capita per country and year) between the treatment country and its synthetically generated control group. Sweden is represented by the solid black line. The dashed line represents Slovakia.

Figure 10: Placebo Test (sample 3, carbon tax countries)

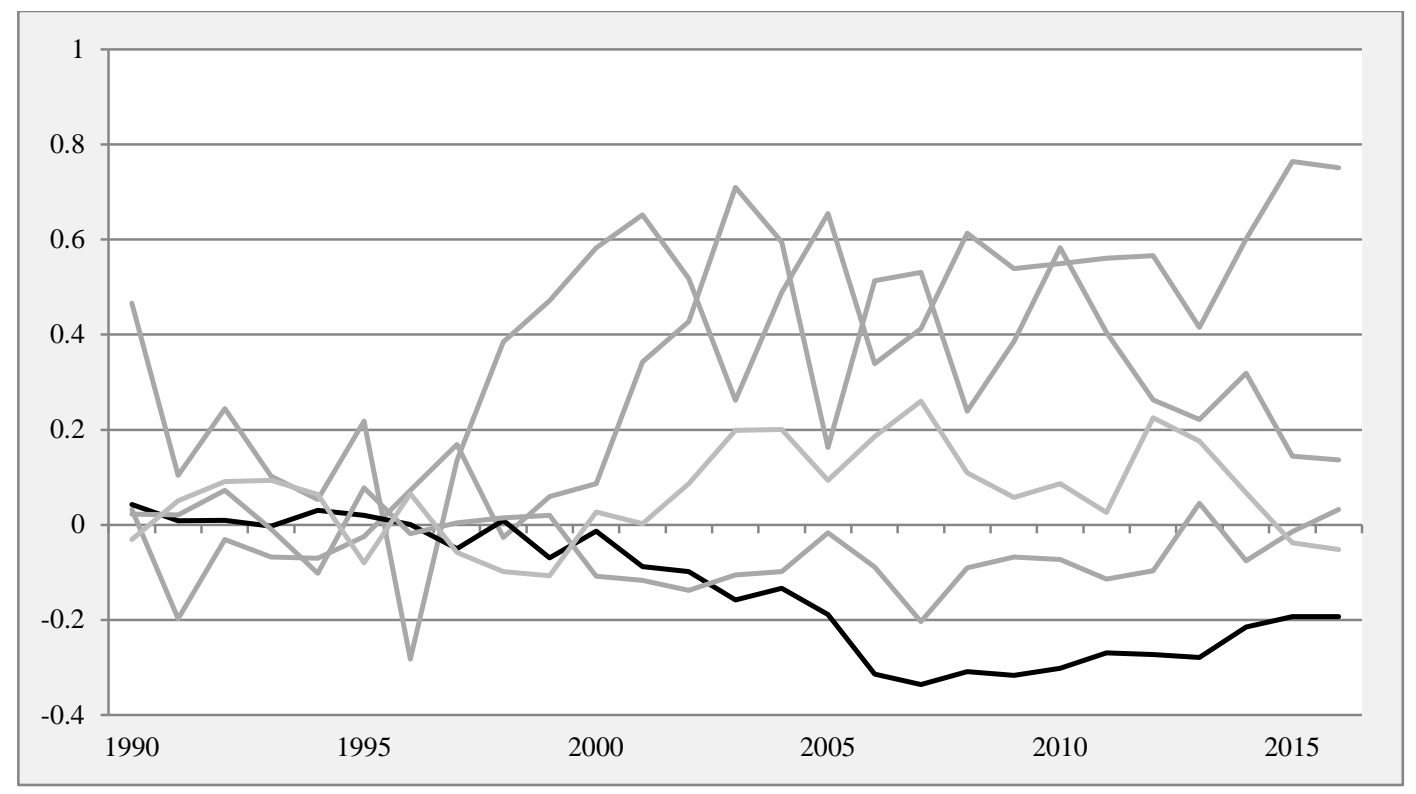

Notes: Each placebo tests (each line) treats one country as the treatment country, regardless of whether treatment was actually received or not. Each line displays the difference in the dependent variable (residential $\mathrm{CO}_{2} /$ capita per country and year) between the treatment country and its synthetically generated control group. Sweden is represented by the solid black line.

We furthermore ran in-time placebo tests for which we use specification 4. Each line represents a separate Synthetic Control Model each one using another year between 1995 and 2005 as the treatment year. We run these placebo test for sample 1 (figure 11), sample 2 (figure 12) 
and sample 3 (figure 13). As figure 11 shows, no matter which year is defined as the treatment year, differences in carbon emissions only start to decrease around the year 2001 with the major decrease happening between the years 2005 and 2007. The models using earlier years as the treatment year show slightly stronger effects since they capture the low treatment intensity effects of the earlier carbon tax scheme.

Figure 11: In Time Placebo Test (sample 1)

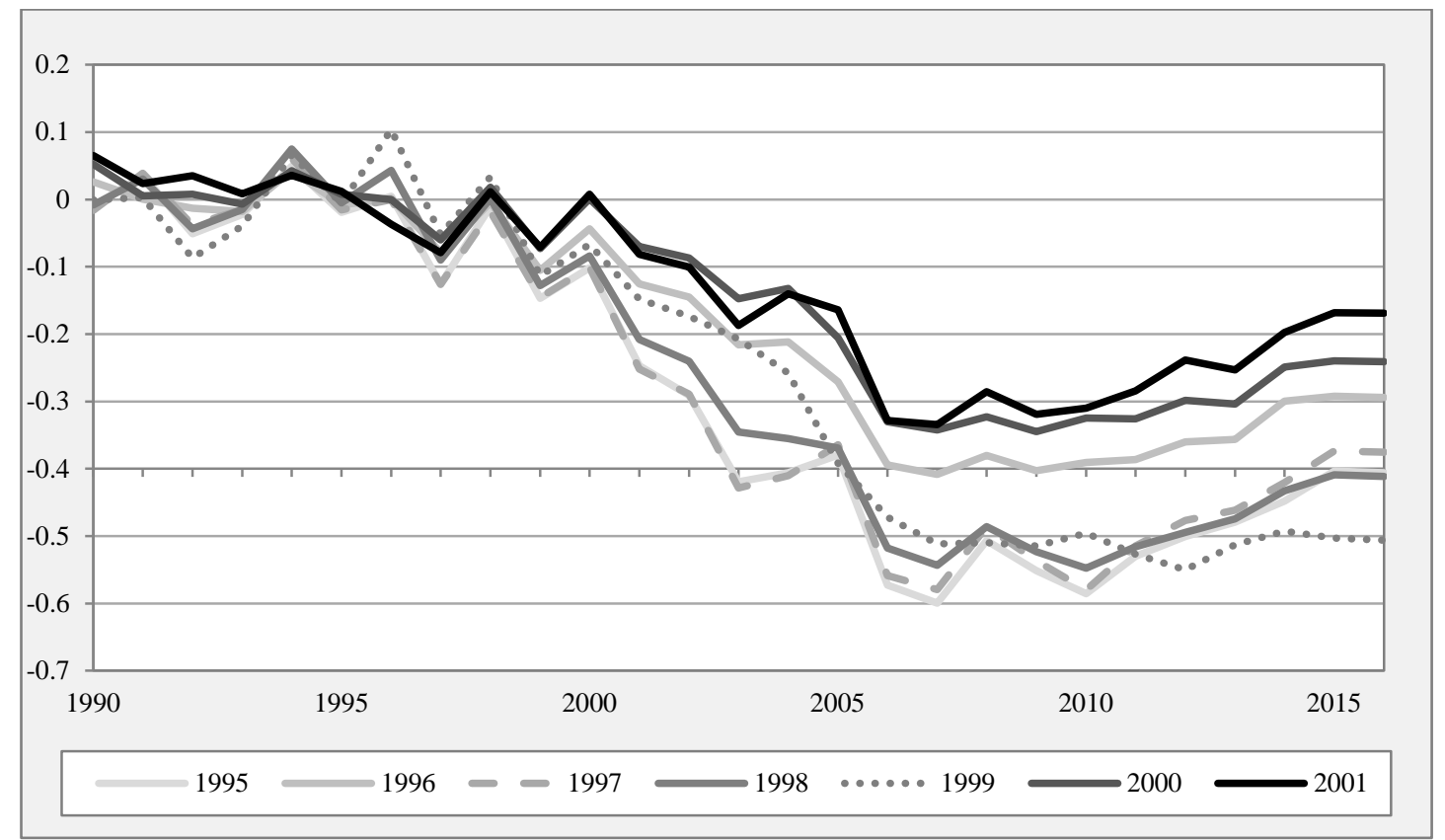

Notes: Each placebo tests (each line) treats one year as the beginning of treatment, regardless of whether treatment was actually received or not. Each line displays the difference in the dependent variable (residential $\mathrm{CO}_{2} /$ capita per country and year) between the treatment country (Sweden) and its synthetically generated control group.

The results of the in time placebos for sample 2 show hardly any differences between the different treatment years. However, in comparison to sample 1 the treatment already shows partial effects starting in the year 1998. This could be due to anticipation effects. Major reduction in $\mathrm{CO}_{2}$ emissions were achieved in the time frame between 1998 and 2007.

The results of the in time placebo tests for sample 3 show equally similar results to the results of sample 1 . The reduction in carbon emissions starts around the year 2001 and experiences the steepest decrease between 2004 and 2006. 
Figure 12: In Time Placebo Test (sample 2)

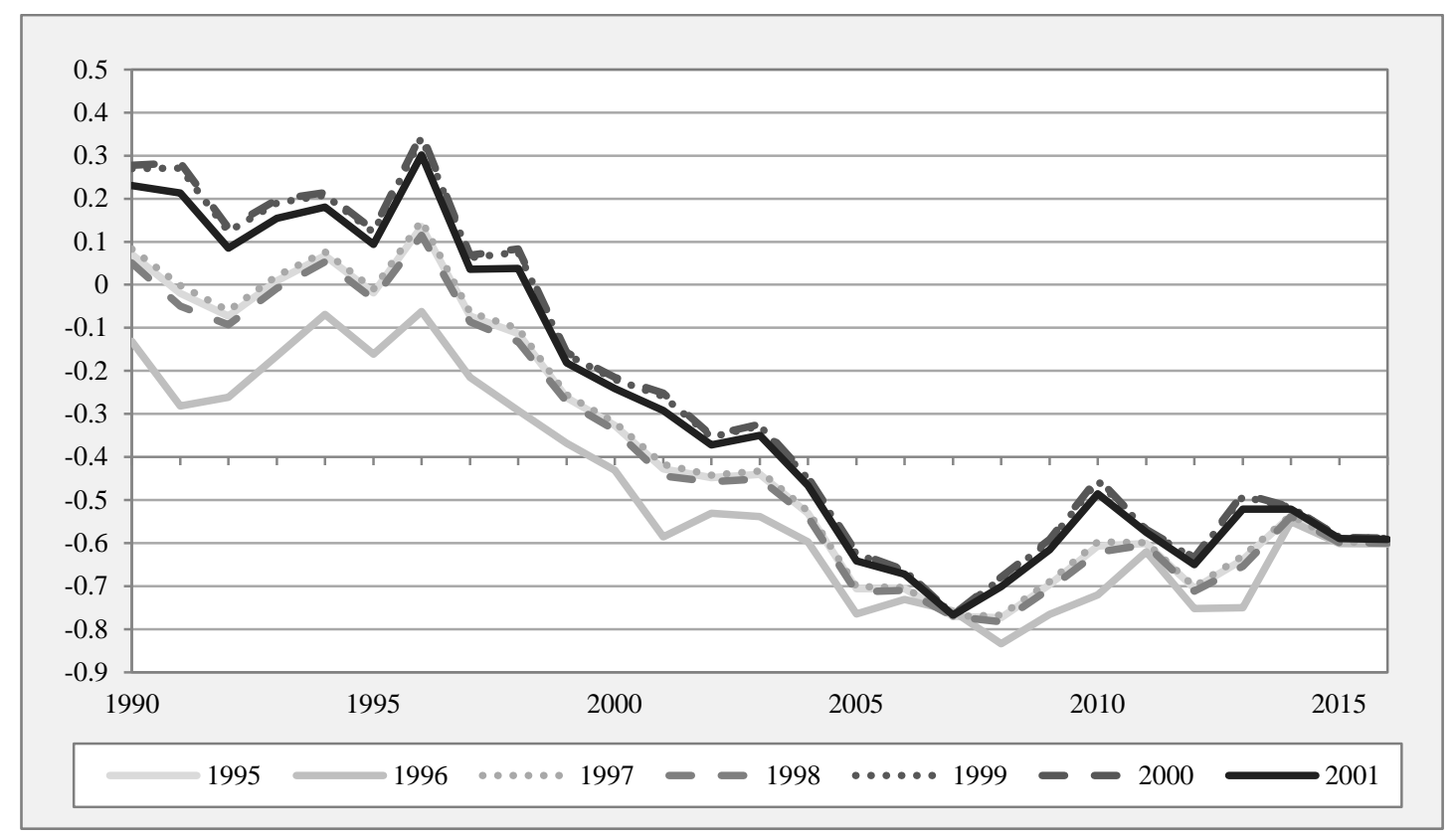

Figure 13: In Time Placebos (sample 3)

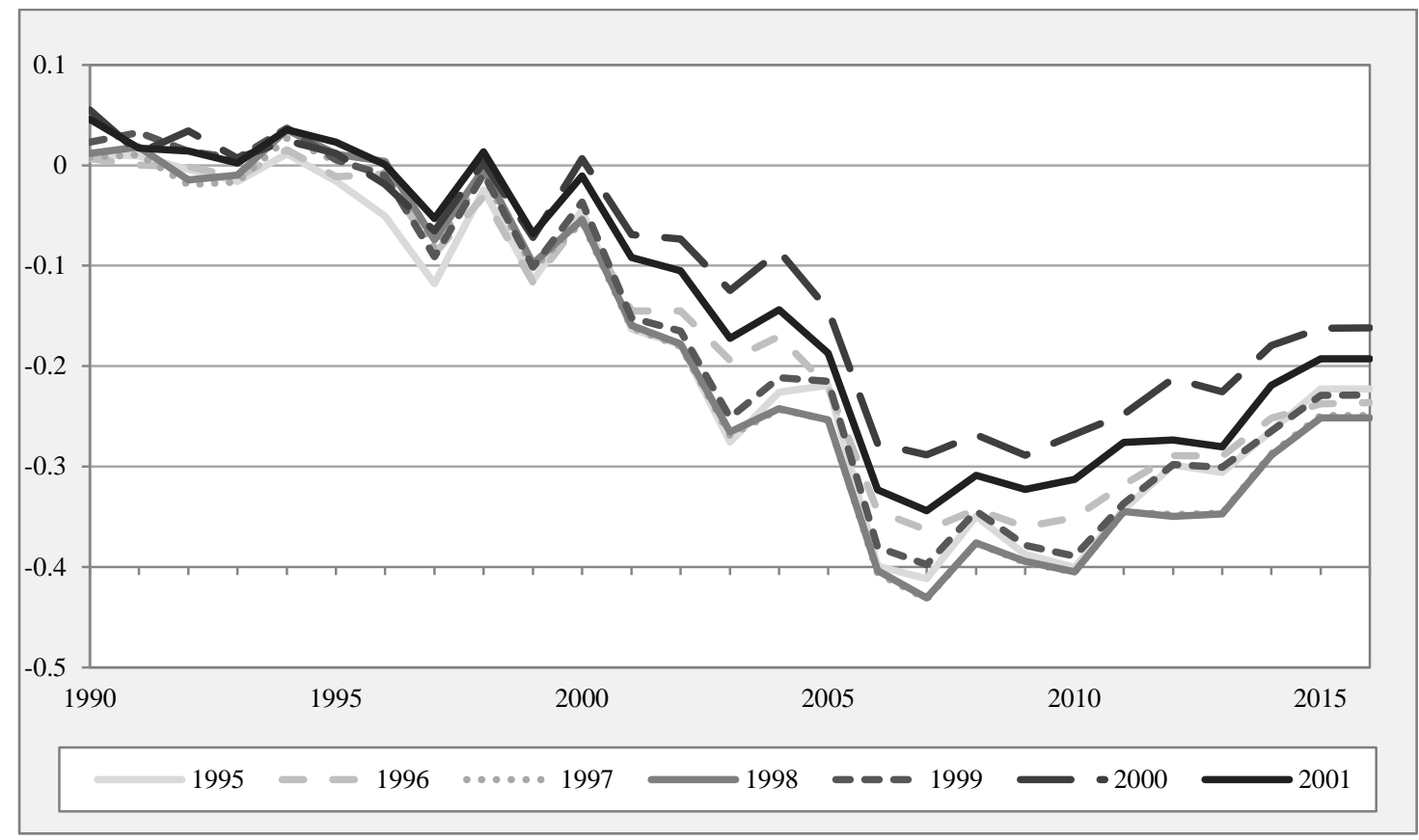




\section{Discussion}

The results of this study show strong and robust negative effects of the Swedish carbon tax increase in the early 2000s on residential carbon emissions. The results suggest that per capita carbon emissions are reduced by between 200 and $800 \mathrm{~kg}$ per year. As some of our lower bound estimates are most likely underestimating the true effect, the effect size should be regarded as high, given that average yearly residential per capita carbon emissions are close to 1.75 tons of $\mathrm{CO}_{2}$ (authors own calculation based on data by Odyssee Mure on residential $\mathrm{CO}_{2}$ emissions divided by the population).

The results therefore suggest the carbon tax to be an effective instrument in reducing residential carbon emissions. The scope of the carbon tax determines its effect size. The strong reductions of residential carbon emissions are driven by the carbon tax increase in the early 2000s. Comparing the development of Swedish residential $\mathrm{CO}_{2}$ emissions with a weighted combination of countries with a carbon tax between 20 and 80 Euros we still find considerable reductions of residential carbon emissions by around 250-350 kg of $\mathrm{CO}_{2}$.

\section{Confounding Factors}

The results we presented in this paper can only be plausibly claimed to be causal if no other confounding factors exist. If there are major energy policy changes in Sweden around the year 2000 besides the increase in carbon taxation, causal identification fails. We therefore investigated changes to the energy policy mix by analyzing the MURE policy data base(OdysseeMure), the 2019 Review of Swedish energy policies by the IEA (International Energy Agency 2019) as well as interviewing officials in the energy agency and the ministry of environment (also see Thonipara et al. 2019) in order to detect potential confounding factors.

Besides the Swedish energy and carbon taxation, Sweden implemented several programs to enhance and support a shift away from heating oil to more renewable heat sources by offering investment grants for small scale biofuel-fired heating systems (2006) or supporting conversions to heating systems based on renewable fuels, district heating, solar heating and heatpumps (2006) or investments for photovoltaic cells (2013). However, these measures were only implemented in the year 2006 or 2013 and can thus not be the driver for the steep $\mathrm{CO}_{2}$ emissions decline after the year 2000. Besides, the Mure impact evaluation assesses the impact of investment grants for small scale biofuel-fired heating systems as rather small, whilst even though the support for heating systems based on renewable fuels, district heating, solar heating or heat pumps was assigned a medium impact, the carbon tax was named as the 
driving factor for these conversions of heating systems. Overall, the stringent energy and carbon taxation was the only policy which was evaluated as having had a high impact.

Other programs before the carbon tax increase such as technology procurement groups (1989), labelling of domestic appliances and windows (1995) were only found to having had a low impact.

Table 4: Swedish Energy Policies

\begin{tabular}{lcc} 
Policy & $\begin{array}{c}\text { Year of implementa- } \\
\text { tion }\end{array}$ & $\begin{array}{c}\text { Mure Impact } \\
\text { Evaluation }\end{array}$ \\
\hline Technology procurement groups & 1989 & Low \\
Energy and carbon tax (in household sector) & 1991 & High \\
Labelling of domestic appliances and windows & 1995 & Low \\
\hline $\begin{array}{l}\text { Investments grants for small scale biofuel-fired heating sys- } \\
\text { tems and more energy efficient windows }\end{array}$ & 2006 & Low \\
$\begin{array}{l}\text { Support for conversion from direct electric heating systems } \\
\text { in households to system based on renewable fuels, district } \\
\text { heating, solar heating or heat pump }\end{array}$ & 2006 & Medium \\
$\begin{array}{l}\text { Energy Performance of Buildings (2002/91/EC) } \\
\text { Investment support for photovoltaic cells }\end{array}$ & 2008 & Unknown \\
\hline
\end{tabular}

Source: data based on Mure energy policy data base (Odyssee-Mure)

Moreover building regulations could have had an impact on reduced residential $\mathrm{CO}_{2}$ emissions. However, as Thonipara et al (2019) argue, Sweden has already had very strict regulatory standards for buildings since 1978. Standards were afterwards only tightened in 2007. Considering that effects of the 2007 modification of building standards would only result in decreasing energy consumption after a number of years (Ó Broin et al. 2019) and that the major reduction of $\mathrm{CO}_{2}$ emissions was achieved between 1995 and 2007, building part regulations cannot be considered as the driving factors of the carbon emissions reduction.

As a means of becoming more independent from oil in the aftermath of the oil shocks in the 1970s, Sweden reinforced its nuclear power. Thus, one might argue that Swedish households were particularly well suited to switching to low-carbon technologies because of relatively inexpensive nuclear powered electricity generation. However, as figure 14 shows, Swedish electricity prices -even when considering purchasing power parities- have never been below the European average for the whole time-period after 2001. Up until 2000 Swedish electricity prices were around the upper average price for electricity in the European Union. After 2000, however, Swedish electricity prices were clearly above European average. Hence, low elec- 
tricity prices do not seem to be a prerequisite for a successful low-carbon technology transition given a high carbon tax.

Figure 14: Electricity Prices by country and year

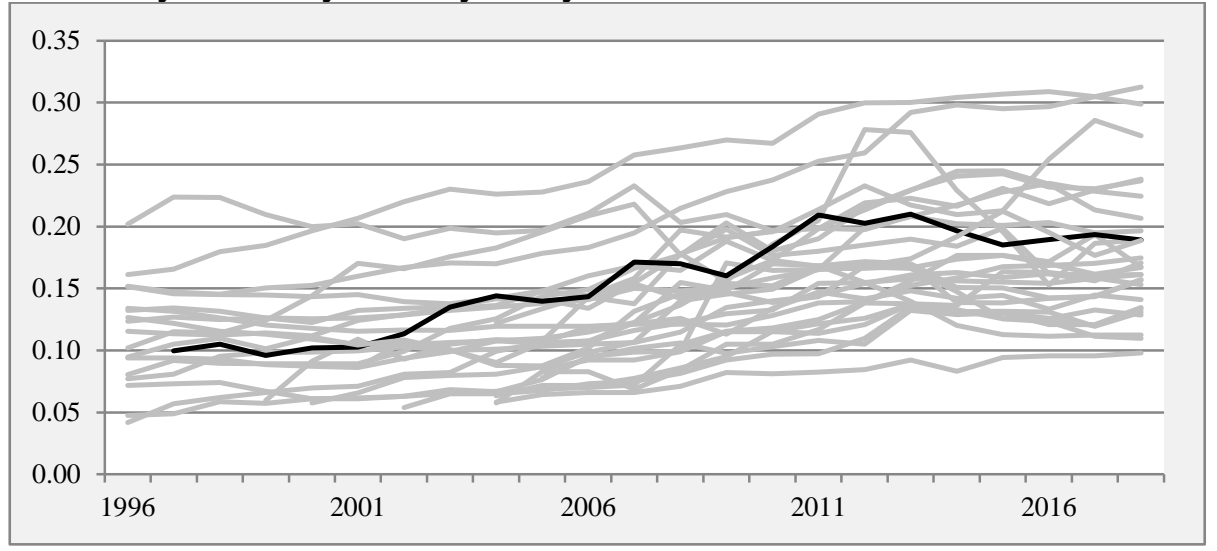

Source: own elaboration, based on data by the OECD

Notes: Prices (including taxes and levies) in Euro (PPP) per Kilowatt-hour

Finally, district heating could have affected residential $\mathrm{CO}_{2}$ emissions reductions as district heating is the major supplier for heat demand in Swedish residential buildings (International Energy Agency 2019) and our expert interviews further confirmed the high relevance of district heating for energy conservation in Swedish residential buildings. Sweden was able to transform the district heating supply from mostly oil and coal to biomass and municipal waste (International Energy Agency 2019). However, the Swedish carbon tax is in this regards considered by the IEA as the main driver of this fuel transition within the Swedish district heating system (International Energy Agency 2019). Furthermore, as Thonipara et al (2019) argue while both Finland and Sweden exhibit similarly high district heating shares levels of energy consumption decline only in Sweden after the year 2000 implying a reduction in carbon emissions. Furthermore, we controlled for the share of district heating in our model and robustness tests. Yet, the effects did not change considerably in the models including the share of district heating.

After a thorough search, we believe there are no major Swedish policy changes that can plausibly explain the fall of residential carbon emissions in the period between 2000 and 2006, except for the carbon tax increase in the early 2000.

\section{Secondary Micro-level Evidence}

The statistical results in previous sections of this paper play out on the macro level. It is, however, desirable to examine the micro-level actions that bring about these carbon emission 
reductions. The remainder of this section presents secondary evidence that corroborates the empirical results above.

Figure 15 displays the consumption of energy carriers in Sweden after the year 1990 (the year 1990 being the index year). One can see that oil consumption exhibits a strongly decreasing trend. However, the main decrease of oil consumption happened between the years 2000 and 2007, right after the carbon tax increase. At the same time electricity, district heating and wood consumption increased slightly after the year 2000. Gas consumption increased before the 2000s and decreased afterwards which could be interpreted as consumers initially switching from oil to gas, and, after the large upwards adjustment of the carbon tax, they started transitioning to electricity, district heating or wood instead.

Figure 15: Development of energy consumption by energy carrier

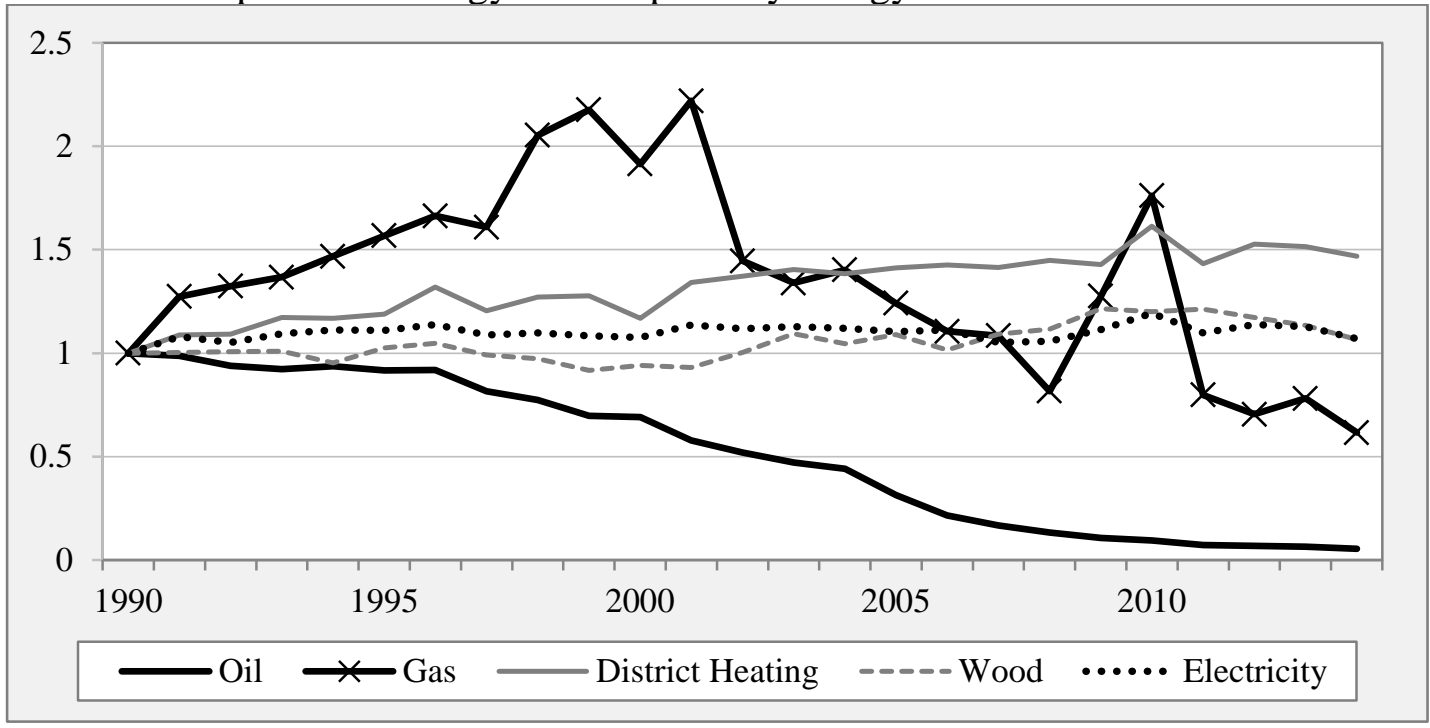

Source: own elaboration based on data by (Odyssee-Mure)

One way of increasing energy efficiency and thus, mitigating residential carbon emissions is the use of heatpumps. Figure 16 shows the development of the sales of heatpumps in Sweden. Between 1990 and 2000 annual sales of heatpumps hovered around 18,000 and 23,000. One can see that with the strong augmentation of the carbon tax in the early 2000s, the sales of heatpumps skyrocketed from 25,000 to 60,000 , which suggests that private households responded quickly to the increasing energy costs by switching to low-carbon technologies.

A high carbon tax leads, of course, to welfare losses in the short-run. Due to the rapid adjustment to the price signal and the corresponding transition to low-carbon-technologies, it can however, arguably enhance overall welfare from an intergenerational perspective. 
Figure 16: Annual Sales of Heatpumps (left hand axis) and Swedish Carbon Tax Rate in SEK per ton of $\mathrm{CO}_{2}$ (right hand axis)

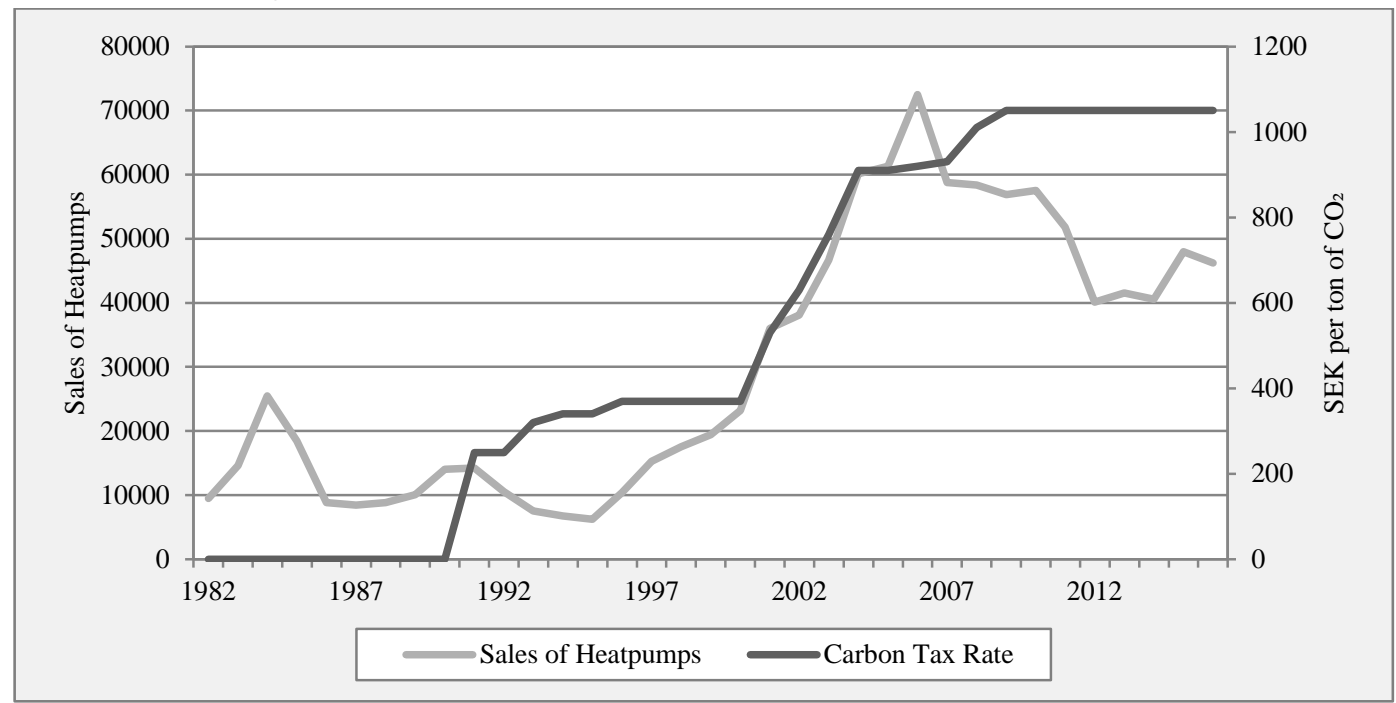

Source: Svenska Kyl \& Värmepump Föreningen; (Hammar and Åkerfeldt 2012)

\section{The reduction of residential carbon emissions in Slovakia}

The SCM results in table 7 and 8 provide evidence that Sweden is the only country in which carbon emissions fell in the time-period after the year 2000, with one exception, i.e. Slovakia. For the placebo tests, we cycled through all sample countries, pretending that they received treatment and thus performed several Synthetic Control Analyses. However, residential carbon emissions after 2000 decreased only in the case of Sweden and Slovakia. In the case of the former country, we interpret the fall in emissions as evidence for the effectiveness of the considerable increase in the carbon tax rate. In this section, we investigate changes in the energy policy mix in Slovakia by checking the MURE database on energy policies in European countries, as well as by interviewing officials in the Slovakian energy agency and by searching relevant publications.

There are two major policy changes that occur right around the turn of the millennium that are likely candidates for driving the emission decline in Slovakia, the elimination of heat subsidies and the expansion of nuclear power.

First, subsidies for heating were abolished almost completely in the year 2000. Von Moltke et al. (2004) show that heat subsidies in the Slovak Republic between 1993 and 1999 sum to more than 1.6 billion US dollars, about half of which came in the form of crosssubsidies (p.68-70, see fig. 4.3). Three quarters of energy subsidies were spent on fossil fuels. In the year 2000, subsidies "were almost entirely removed" (p.69). Furthermore, looking at OECD data on energy carrier specific consumption, prices and taxes, we can see that the most 
important residential energy source in Slovakia is gas (year 2000: 1.64 Mtoe), followed by district heat (0.4 Mtoe) and electricity (0.46 Mtoe). Gas prices increase almost sixfold between the year 2000 and 2008 (from 9.9 to 56.7 US\$ / MhWh). Similarly the tax paid per MWh increases from 0.8 to 9 US\$ / MWh. After the elimination of subsidies, the residential consumption of gas falls to 1.1 Mtoe in 2007, a reduction of about $31 \%$.

Second, new nuclear power plants were built in the early 2000s (IEA, 2018, 19-22) ${ }^{5}$. Total primary energy supply in Slovakia amounts to about 19 Mtoe in 2000. The supply of nuclear energy increased from about 3 Mtoe (1998) to about 5 Mtoe (2003). Both, the expansion of nuclear power as well as the elimination of subsidies and tax increases most likely contribute to the fall in residential emissions in the Slovak Republic.

\section{Conclusion}

We study the impact of Swedish carbon taxation on carbon emissions in the residential sector. Using macro level data on residential carbon emissions, we firstly estimate Difference-inDifference regressions, treating the Swedish increase in carbon taxation after the year 2000 as a quasi-experimental intervention. While the DiD-results support our hypothesis of a negative impact of carbon taxation on carbon emissions in the residential sector, the DiD-evidence must be seen as suggestive rather than strictly causal. The Swedish carbon tax has been introduced in 1991 and was steadily and slightly increased throughout the 1990s, until the major upward shift occurred after 2001, thereby jeopardizing a clean distinction between a pre- and post-treatment period.

In order to overcome the shortcomings of the DiD approach, we secondly perform a synthetic control analysis. A weighted combination of donor countries serves as a synthetic Sweden without the intervention (i.e. the counterfactual). We find evidence for a causal impact of the tax increase and lower emissions in the residential sector. Using various sets of control group countries, we estimate a large effect size when comparing Sweden with countries that have not implemented a carbon taxation scheme, i.e. a reduction of residential carbon emissions per capita and year by $800 \mathrm{~kg}$. When comparing Sweden, with its high carbon tax level, to countries that have implemented lower carbon taxation levels, we still find a moderate reduction of around $300 \mathrm{~kg}$ per capita per year. In-time placebo tests as well as country placebo tests suggest that these results are robust.

\footnotetext{
${ }^{5}$ Also see https://www.iea.org/statistics
} 
We finally show that other energy policies were not able to drive the carbon emissions reductions in the early 2000s and rule out the possibility of the fuel transition in the Swedish district heating system causing the sharp carbon emissions reductions instead of the carbon tax increasing by controlling for the share of district heating in our model. We further present a number of descriptive Swedish time series statistics on fuel-type consumption and sales of low-carbon heating systems that corroborate our hypothesis. The timing of oil-substitution as well as the increase in heat-pump-sales coincides with the carbon tax increase after the year 2000. We also rule out the possibility of inexpensive nuclear powered electricity generation as a prerequisite for a low-carbon-technology transition as Sweden does not display particularly low electricity prices when compared to other countries.

Our results suggest that carbon taxation can be an effective policy tool in lowering emissions in the residential sector if taxation levels exceed 120 Euros per ton of $\mathrm{CO}_{2}$ as it is the case in Sweden. Since there are also strong theoretic reasons in favour of its efficiency vis-àvis alternative climate policies (command and control methods), which generally exhibit higher bureaucratic costs, carbon taxation may become a more attractive policy tool in the future.

Our research is limited by the fact, that we do not fully investigate differing treatment intensity levels, i.e. heterogeneous tax rates, as there currently exists no information on carbon taxation rates for multiple countries over time. Instead, we used the substantial increase in the Swedish carbon tax as a binary treatment variable. Future research may want to concentrate on generating and exploiting a richer data set on taxation levels in order to yield more nuanced results. 


\section{References}

Abadie, A. and Gardeazabal, J. 2003. The Economic Costs of Conflict: A Case Study of the Basque Country, The American Economic Review, Vol. 93, No. 1: 113-132.

Abadie, A., Diamond, A. and Hainmueller, J. 2010. “Synthetic Control Methods for Comparative Case Studies: Estimating the Effect of California's Tobacco Control Program.” Journal of the American Statistical Association 105 (490): 493-505.

Abadie, Alberto, and Hainmueller, J. 2014. “Comparative Politics and the Synthetic Control Method Alexis Diamond - International Finance Corporation.” American Journal of Political Science.

Abadie, A., Diamond, A. and Hainmueller, J. 2015. "Comparative Politics and the Synthetic Control Method.” American Journal of Political Science 59 (2): 495-510.

Anderson, S.T. and Newell, R.G. 2004. "Information Programs for Technology Adoption: The Case of Energy-Efficiency Audits.” Resource Energy Economics 26 (1): 27-50.

Andersson, J. 2017. “Cars, Carbon Taxes and CO2 Emissions.” Grantham Research Institute on Climate Change and the Environment, Working Paper, no. 238.

Arens, M., Worrell, E. and Eichhammer, W. 2017. "Drivers and Barriers to the Diffusion of Energy-Efficient Technologies—a Plant-Level Analysis of the German Steel Industry.” Energy Efficiency 10 (2). Energy Efficiency: 441-57.

Bohlin, F. 1998. "The Swedish Carbon Dioxide Tax: Effects on Biofuel Use and Carbon Dioxide Emissions.” Biomass and Bioenergy 15 (4-5). Pergamon: 283-91.

Bureau, B. 2011. “Distributional Effects of a Carbon Tax on Car Fuels in France.” Energy Economics 33 (1): 121-30.

Chapa, J., and Ortega, A. 2017. “Carbon Tax Effects on the Poor: A SAM-Based Approach.” Environmental Research Letters 12 (9).

Di Cosmo, V. and Hyland, M.. 2013. “Carbon Tax Scenarios and Their Effects on the Irish Energy Sector.” Energy Policy 59 (August). Elsevier: 404-14. 
Dong, H., Dai, H., Geng, J., Fujita, T.; Liu, Z., Xie, Y., Wu, R., Fujii, M., Masui, T.and Tang, L. 2017. “Exploring Impact of Carbon Tax on China’s CO2 Reductions and Provincial Disparities.” Renewable and Sustainable Energy Reviews 77 (September). Pergamon: 596-603.

Dukan, M. 2019. “Energy Efficiency Policy Instruments in the European Union.” The Climate Policy Info Hub. 2019. https://climatepolicyinfohub.eu/energy-efficiencypolicy-instruments-european-union.

Elliott, J., and Fullerton, D. 2014. “Can a Unilateral Carbon Tax Reduce Emissions Elsewhere?” Resource and Energy Economics 36 (1). North-Holland: 6-21.

European Commission. 2011. Roadmap for Moving to a Competitive Low Carbon Economy in 2050.

Filippini, M., Hunt, L.C. and Zorić, J.. 2014. “Impact of Energy Policy Instruments on the Estimated Level of Underlying Energy Efficiency in the EU Residential Sector.” Energy Policy 69: 73-81.

Gonzalez, F. 2012. “Distributional Effects of Carbon Taxes: The Case of Mexico.” Energy Economics 34 (6). North-Holland: 2102-15.

Hammar, H. and Åkerfeldt, S. 2012. “CO 2 Taxation in Sweden 20 Years of Experience and Looking Ahead.”

IEA, International Energy Agency. 2018. “Energy Policies of IEA Countries: Slovakia 2018 Review.”

IEA, International Energy Agency. 2019. “Energy Policies of IEA Countries: Sweden 2019 Review.”

Jiang, Z. and Shao, S. 2014. "Distributional Effects of a Carbon Tax on Chinese Households: A Case of Shanghai.” Energy Policy 73 (October). Elsevier: 269-77.

Levinson, A. 2016. “How Much Energy Do Building Energy Codes Really Save? Evidence from California.” American Economic Review 106 (10): 2867-94.

Lin, B. and Li, X. 2011. “The Effect of Carbon Tax on per Capita CO2emissions.” Energy Policy. 
Mcclelland, R. and Gault, S. 2017. "The Synthetic Control Method as a Tool to Understand State Policy,” no. March.

Mori, K. 2012. "Modeling the Impact of a Carbon Tax: A Trial Analysis for Washington State.” Energy Policy 48 (September). Elsevier: 627-39.

Ó Broin, E., Nässén, J. and Johnsson, F. 2015. “The Influence of Price and Non-Price Effects on Demand for Heating in the EU Residential Sector.” Energy 81 (March). Pergamon: $146-58$.

Ó Broin, E., Ewald, J., Nadaud, F, Mata, E., Hennlock, M.; Giraudet, L., Sterner, T. 2019. “An Ex Post Evaluation of Energy-Efficiency Policies across the European Union”

Odyssee-Mure. n.d. “Database.” http://www.odyssee-mure.eu/.

Parry, I. 2015. “Carbon Tax Burdens on Low-Income Households: A Reason for Delaying Climate Policy?” CESifo Working Paper Series 5482.

Renner, S. 2018. “Poverty and Distributional Effects of a Carbon Tax in Mexico.” Energy Policy 112 (January). Elsevier: 98-110.

Shmelev, S. E. and Speck, S.U. 2018. “Green Fiscal Reform in Sweden: Econometric Assessment of the Carbon and Energy Taxation Scheme.” Renewable and Sustainable Energy Reviews 90 (March): 969-81..

Sweden, Government Offices of. 2018. “Sweden’s Carbon Tax.” 2018. http://www.government.se/government-policy/taxes-and-tariffs/swedens-carbon-tax/.

Thonipara, A., Runst, P., Ochsner, C. and Bizer,K. 2019. “Energy Efficiency of Residential Buildings in the European Union - An Exploratory Analysis of Cross-Country Consumption Patterns.” Energy Policy 129 (June). Elsevier: 1156-67.

United Nations. 2018. “World 'Nearing Critical Point of No Return’ on Climate Change, Delegate Warns, as Second Committee Debates Sustainable Development.” 2018. https://www.un.org/press/en/2018/gaef3500.doc.htm.

World Bank. 2018. State and Trends of Carbon Pricing 2018. . 2019. Carbon Pricing Dashboard. 2019. https://carbonpricingdashboard.worldbank.org/map_data. 


\section{Appendix}

\section{A Data Sources}

\section{Table A1: Data Description}

\begin{tabular}{llll} 
Variable & Name & Unit & Source \\
\hline Poil & Price on oil & USD per 1000 litres of light fuel oil & OECD \\
Pelec & Price on gas & USD per MWh natural gas & OECD \\
\hline GDPpC & Price on electricity & USD per MWh electricity & Worldbank \\
GDPpC2 & GDP per capita squared & USD (2010) & Worldbank \\
Population & Population & USD (2010) & Odyssee-Mure \\
\hline Co2E & $\mathrm{CO}_{2}$ Emissions in the residential sector & Million tons of $\mathrm{CO}_{2}$ & Odyssee-Mure \\
CO2EpCalt & $\mathrm{CO}_{2}$ Emissions per capita mt & Million tons of $\mathrm{CO}_{2}$ & Odyssee-Mure \\
CO2EpC & $\mathrm{CO}_{2}$ Emissions per capita & Tons of CO ${ }_{2}$ & Odyssee-Mure \\
\hline HDD & Heating Degree Days & Days & Odyssee-Mure \\
District heat & Share of district heating & Percentage & Odyssee-Mure \\
\hline
\end{tabular}


B. Descriptive Statistics

Table B1: Descriptive Statistics of Data Set

\begin{tabular}{lccccc}
\multicolumn{1}{c}{ Variable } & Obs & Mean & Std. Dev. & Min & Max \\
& & & & & \\
\hline Year & 513 & 2003 & 7.80 & 1990 & 1055 \\
Toil & 511 & 255.68 & 221.82 & 6 & 2091 \\
Poil & 512 & 717.03 & 440.44 & 43.12 & 409.19 \\
Pelec & 512 & 166.47 & 74.82 & 10.3 & $111,968.30$ \\
\hline GDPpC & 513 & $41,928.24$ & $21,786.85$ & $5,510.66$ & 1,030 \\
GDPpC2 (x 1 Mio) & 513 & 2,230 & 2,340 & 3,040 & 14,783 \\
Co2E & 503 & 730.77 & 2902.18 & 0.64 & 3.73 \\
CO2EpC & 503 & 1.76 & 0.75 & 0.13 & 82.5 \\
\hline Population (x 1 Mio) & 513 & 23.2 & 24.7 & 3.8 & 4947 \\
HDD & 513 & 2885.92 & 8405898 & 7772633 & 0.37 \\
District heat & 488 & 0.10 & 0.12 & 0 & \\
\hline
\end{tabular}




\section{Additional Results}

Table C1: Weighted Combinations of Synthetic Sweden (sample1)

\begin{tabular}{|c|c|c|c|c|c|}
\hline Country & Specification 1 & Specification 2 & Specification 3 & Specification 4 & $\begin{array}{l}\text { Including share } \\
\text { district heating }\end{array}$ \\
\hline Austria & 0.003 & 0 & 0 & 0 & 0 \\
\hline $\begin{array}{l}\text { Belgium } \\
\text { Czech }\end{array}$ & 0.001 & 0 & 0 & 0 & 0 \\
\hline Republic & 0.001 & 0.107 & 0 & 0 & 0 \\
\hline Denmark & 0.118 & 0.153 & 0.14 & 0.14 & 0.141 \\
\hline Finland & 0.003 & 0 & 0 & 0 & 0 \\
\hline France & 0.003 & 0 & 0 & 0 & 0 \\
\hline Germany & 0.001 & 0 & 0 & 0 & 0 \\
\hline Greece & 0.001 & 0 & 0 & 0 & 0 \\
\hline Ireland & 0.001 & 0 & 0 & 0 & 0 \\
\hline Italy & 0.003 & 0 & 0 & 0.107 & 0.118 \\
\hline Netherlands & 0.001 & 0 & 0 & 0 & 0 \\
\hline Norway & 0.657 & 0.74 & 0.709 & 0.647 & 0.643 \\
\hline Poland & 0.202 & 0 & 0.062 & 0.106 & 0.098 \\
\hline Slovakia & 0 & 0 & 0 & 0 & 0 \\
\hline Spain & 0.001 & 0 & 0 & 0 & 0 \\
\hline Switzerland & 0.002 & 0 & 0 & 0 & 0 \\
\hline UK & 0.001 & 0 & 0.089 & 0 & 0 \\
\hline RMSPE & 0.05 & 0.04 & 0.03 & 0.03 & 0.04 \\
\hline
\end{tabular}

Table C2: Weighted Combinations of Synthetic Sweden (sample 2)

\begin{tabular}{lccccc}
\hline Country & Specification 1 & Specification 2 & Specification 3 & Specification 4 & $\begin{array}{c}\text { Including share dis- } \\
\text { trict heating }\end{array}$ \\
\hline Austria & 0 & 0 & 0 & 0 & 0 \\
Belgium & 0 & 0 & 0 & 0 & 0 \\
Czech & 0 & 0 & 0 & 0 & 0 \\
Republic & & 0 & 0.385 & 0.492 & 0.385 \\
\hline France & 0 & 0 & 0 & 0 & 0 \\
Germany & 0 & 0 & 0.03 & 0 & 0.03 \\
Poland & 0.135 & 0 & 0 & 0 & 0 \\
\hline Slovakia & 0 & 0.711 & 0.585 & 0.508 & 0.585 \\
Spain & 0.865 & 0.16 & 0.14 & 0.14 & 0.14 \\
\hline RMSPE & 0.14 & & &
\end{tabular}


Table C3: Weighted Combinations of Synthetic Sweden (sample 3)

\begin{tabular}{lccccc}
\hline Country & Specification & Specification & Specification & $\begin{array}{c}\text { Specification } \\
\text { Including share dis- } \\
\text { trict heating }\end{array}$ \\
\hline Denmark & 1 & 2 & 3 & 4 & 0.168 \\
Finland & 0.206 & 0.172 & 0.158 & 0.166 & 0.068 \\
Italy & 0 & 0 & 0 & 0.077 & 0.055 \\
\hline Norway & 0 & 0 & 0 & 0.052 & 0.709 \\
Switzerland & 0.69 & 0.726 & 0.723 & 0.704 & 0 \\
UK & 0 & 0 & 0 & 0 & 0 \\
\hline RMSPE & 0.05 & 0.104 & 0.12 & 0.04 & 0.04 \\
\hline
\end{tabular}


Figure A1: Placebo Test (sample 1, all countries, including the share of district heating)

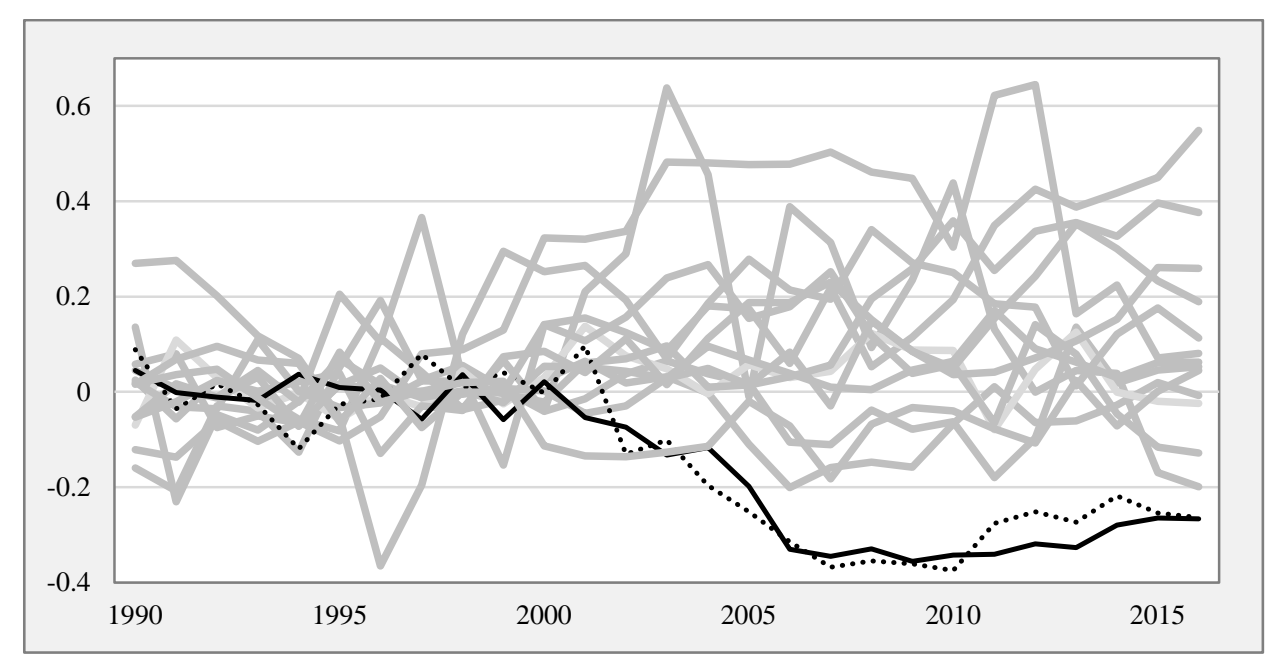

Notes: Each placebo tests (each line) treats one country as the treatment country, regardless of whether treatment was actually received or not. Each line displays the difference in the dependent variable (residential $\mathrm{CO}_{2}$ / capita per country and year) between the treatment country and its synthetically generated control group. Sweden is represented by the solid black line. The dashed line represents Slovakia.

Figure A2: Placebo Test (sample 2, countries with no or low cabon tax and low energy tax, including the share of district heating)

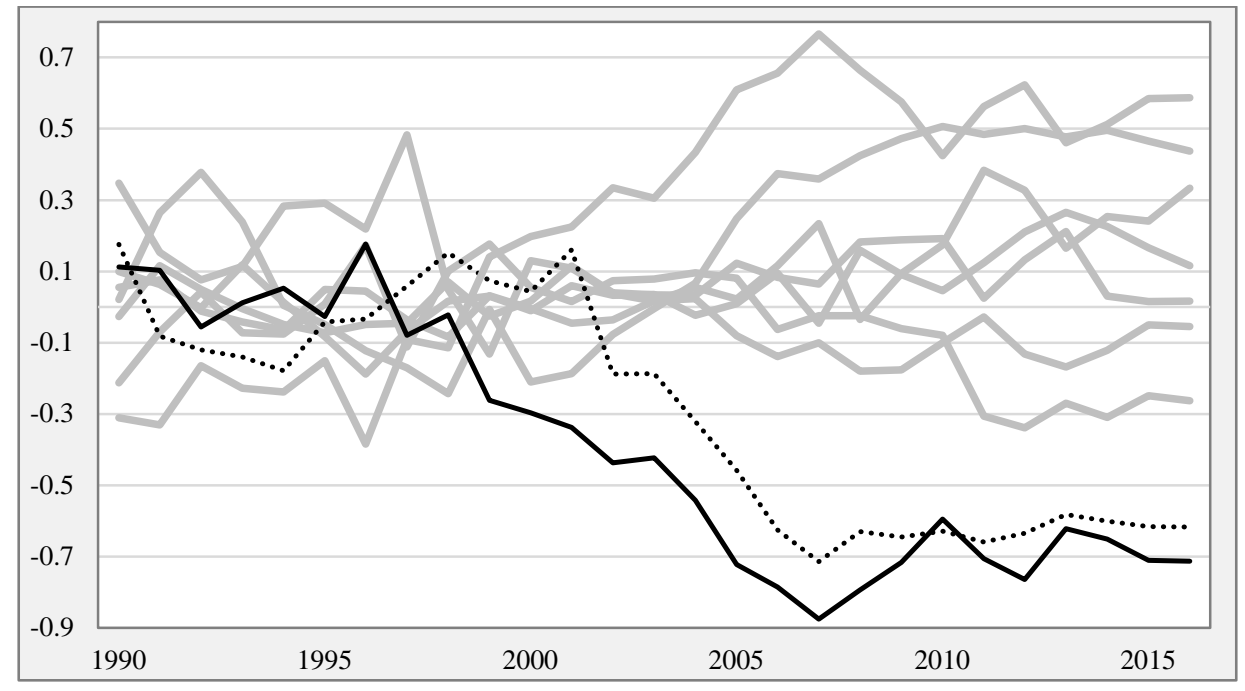

Notes: Each placebo tests (each line) treats one country as the treatment country, regardless of whether treatment was actually received or not. Each line displays the difference in the dependent variable (residential $\mathrm{CO}_{2}$ / capita per country and year) between the treatment country and its synthetically generated control group. Sweden is represented by the solid black line. The dashed line represents Slovakia. 
Figure A3: Placebo Test (sample 3, carbon tax countries, including the share of district heating)

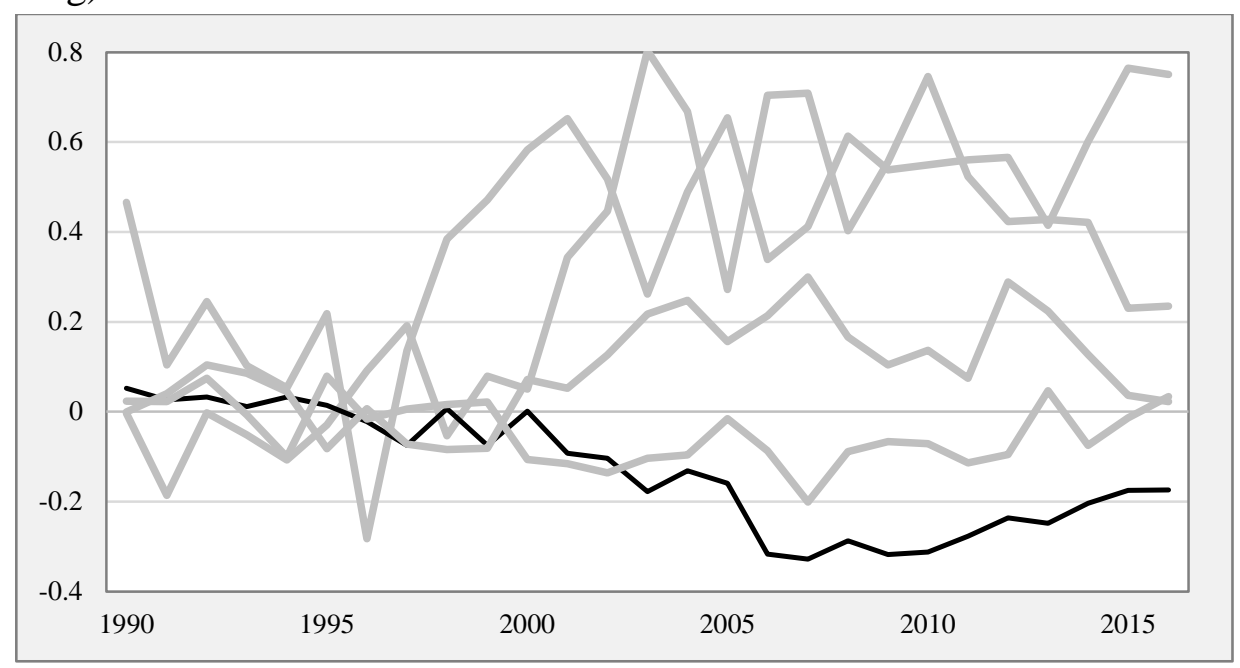

Notes: Each placebo tests (each line) treats one country as the treatment country, regardless of whether treatment was actually received or not. Each line displays the difference in the dependent variable (residential $\mathrm{CO}_{2} /$ capita per country and year) between the treatment country and its synthetically generated control group. Sweden is represented by the solid black line.

Figure A4: In Time Placebo Test (sample 1, all countries)

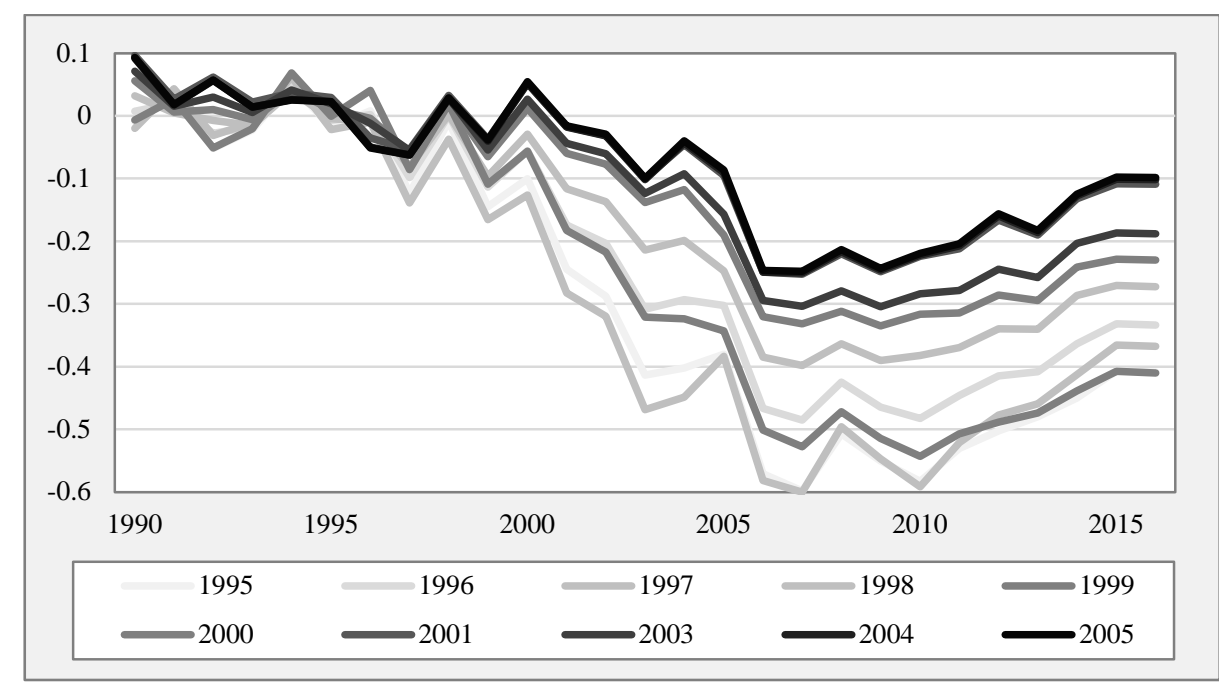




\section{Chapter IV}

\section{Empirische Hinweise auf die Effektivität einer $\mathrm{CO}_{2}$-Besteuerung im Wohngebäudesektor}

With Petrik Runst

Published in:

Wirtschaftsdienst 99 (12), Pages 832-835 (2019) 


\title{
Empirische Hinweise auf die Effektivität einer $\mathrm{CO}_{2}$-Besteuerung im Wohngebäudesektor
}

\author{
Petrik Runst und Anita Thonipara
}

Laut jüngsten Forschungsergebnissen gab es in den letzten 2000 Jahren keine Erwärmungsphasen, welche den gesamten Erdglobus betrafen, außer derjenigen, welche anthropogen nach 1850 einsetzte und ein zentrales Thema aktueller politischer Diskussionen darstellt. ${ }^{1}$ Eine Mehrheit von über 1.100 befragten Energieökonomen ist davon überzeugt, dass marktwirtschaftliche Politikinstrumente, wie der Zertifikate-Handel (ETS) oder eine $\mathrm{CO}_{2}$-Steuer, stärker genutzt werden sollten, um die $\mathrm{CO}_{2}$-Emissionen zu senken und den Folgen des Klimawandels entgegenzuwirken. ${ }^{2}$ Die Ergebnisse aus dem deutschen Ökonomenpanel deuten darauf hin, dass auch deutsche Volkswirte die Erweiterung des ETS oder eine Steuer als adäquate Politikinstrumente betrachten. ${ }^{3}$ Diese Instrumente zeichnen sich dadurch aus, dass sie den Individuen selbst überlassen, ob und auf welche Weise sie $\mathrm{CO}_{2}$ einsparen wollen. Damit sind sie technologieoffen (auch gegenüber aktuell noch unbekannten Technologien) und nutzen den marktwirtschaftlichen Entdeckungsprozess. Theoretisch führen diese marktwirtschaftlichen Politikinstrumente zur Umsetzung von kostengünstigen Maßnahmen, wodurch die $\mathrm{CO}_{2-}$ Vermeidungskosten minimiert werden.

\section{$\mathrm{CO}_{2}$-Steuern als effizientes Instrument}

Im Gegensatz dazu ist die Mehrheit der klimapolitischen Maßnahmen in Deutschland und anderen wohlhabenden Ländern geprägt von konkreten Ge- und Verboten, welche nur begrenzt technologieoffen sind und fortlaufend an den Stand der Technik angepasst werden müssten. Es gibt Hinweise darauf, dass viele dieser konkreten Maßnahmen, beispielsweise die energetische Gebäudesanierung, die $\mathrm{CO}_{2}$-Vermeidungskosten nicht minimieren. ${ }^{4}$ Weiterhin

\footnotetext{
${ }^{1}$ R. Neukom, N. Steiger, J. J. Gomez-Navarro, J. Wang \& J. P. Werner: No evidence for globally coherent warm and cold periods over the preindustrial Common Era, in: Nature, 571, Jg. (2019), S. 550-554.

${ }^{2}$ P. Howard, D. Sylvan: Expert Consensus on the Economics of Climate Change, Institute for Policy Integrity, New York University School of Law, 2015.

${ }^{3}$ J. Blum, R. de Britto Schiller, A. Löschel, J. Pfeiffer, K. Pittel, N.s Potrafke und A. Schmitt: Zur Bepreisung von CO2-Emissionen. Ergebnisse aus dem Ökonomenpanel, in: ifo Schnelldienst, 72. Jg. (2019), H. 16, S. 6065.

${ }^{4}$ P. Runst: Kurswechsel in der deutschen Klimapolitik am Beispiel der energetischen Gebäudesanierung, in: Wirtschaftsdienst, 96. Jg. (2016), H. 5, S. 340-343, https://archiv.wirtschaftsdienst.eu/ jahr/2016/5/kurswechsel-in-der-deutschen-klimapolitik-am-beispielderenergetischen-gebaeudesanierung/ (26.11.2019).
} 
ist bei einigen staatlich geförderten Technologien, wie der Elektromobilität, aktuell noch nicht abzusehen, ob sie überhaupt Emissionen einsparen. ${ }^{5}$

Eine $\mathrm{CO}_{2}$-Steuer existierte bis vor Kurzem in nur wenigen Ländern, wodurch die Datenbasis für empirische Evaluationen fehlte. In den letzten Jahren zeichnete sich allerdings eine Trendwende ab. $\mathrm{CO}_{2}$-Besteuerung wurde in der Schweiz, in Korea, in Japan und anderen Ländern eingeführt. Schweden war eines der ersten Länder, welches sich für diese klimapolitische Strategie entschied. Die schwedische $\mathrm{CO}_{2}$-Steuer, 1990 eingeführt, wurde sukzessive erhöht und sprang zwischen 2001 und 2003 auf über 100 Euro pro t $\mathrm{CO}_{2}$. Mit rund 120 Euro pro Tonne $\mathrm{CO}_{2}$ ist die schwedische Steuer die derzeit höchste der Welt.

Da der Wohngebäudesektor nicht wie der Transport- und Industriesektor einer Vielzahl von Ausnahmeregelungen unterliegt, sondern seit Einführung der $\mathrm{CO}_{2}$ Steuer immer dem vollen Steuersatz unterlag, eignet er sich besonders gut für Untersuchungen. Zwei kürzlich entstandene Studien untersuchen das Fallbeispiel Schweden und finden erste Hinweise auf die Wirksamkeit einer Emissions-Steuer.

\section{Energieverbrauch im Wohngebäudesektor}

Thonipara et al. untersuchen zunächst die Faktoren, welche den Energieverbrauch im Wohngebäudesektor in europäischen Ländern beeinflussen. ${ }^{6}$ In ihrer ökonometrischen Analyse beziehen die Autoren dabei das nationale Einkommen, die durchschnittlichen Wohnungsgrößen sowie klimatische Bedingungen und andere erklärende Variablen ein. Schätzt man nun den Verbrauch aufgrund dieses Modells, ergeben sich länderspezifische Abweichungen zwischen den geschätzten und den tatsächlichen Verbräuchen (vgl. Abbildung 1), welche nicht durch die einbezogenen Variablen erklärt werden können. Beispielsweise verbraucht der Wohngebäudesektor in Luxemburg deutlich mehr Energie als er das auf Grundlage der landesspezifischen Bedingungen (wie Einkommens, Klimas usw.) tun sollte. Umgekehrt verbraucht der Wohngebäudesektor in den skandinavischen Ländern weniger, als auf Grundlage ihrer länderspezifischen Bedingungen geschätzt wurde. Die Länder auf der Nullinie weisen einen ProKopf Energiekonsum auf, wie man ihn für die länderspezifischen Bedinungen erwarten würde. Diese Abweichungen geben Hinweise auf bestimmte Rahmenbedingungen in diesen Ländern, welche den Energieverbrauch beeinflussen. Hierunter fallen insbesondere klimapoliti-

\footnotetext{
${ }^{5}$ C. Leßmann, A. Steinkraus, M. Frondel, M. R. Stuchtey, M. Braun, T. Hamacher, B. Lenz, D. Krajzewicz, G. Liedtke, C. Winkler, K. Pittel: Zukunft der Mobilität: Welche Optionen sind tragfähig?, in: ifo Schnelldienst, 72. Jg. (2019), H. 12, S. 3-24.

${ }^{6}$ A. Thonipara, P. Runst, K. Bizer, C. Ochsner: The Energy Efficiency of Residential Buildings in the European Union, in: Energy Policy, 129. Jg. (2019), S. 1156-1167.
} 
sche Instrumente, welche die Studie in einer zweiten, qualitativen Analyse im Detail betrachtet.

\section{Abbildung 1: Abweichungen vom erwartbaren Energieverbrauch im Wohngebäude- sektor}

Länder-Residuen nach OLS Schätzung des Energieverbrauchs im Wohngebäudesektor

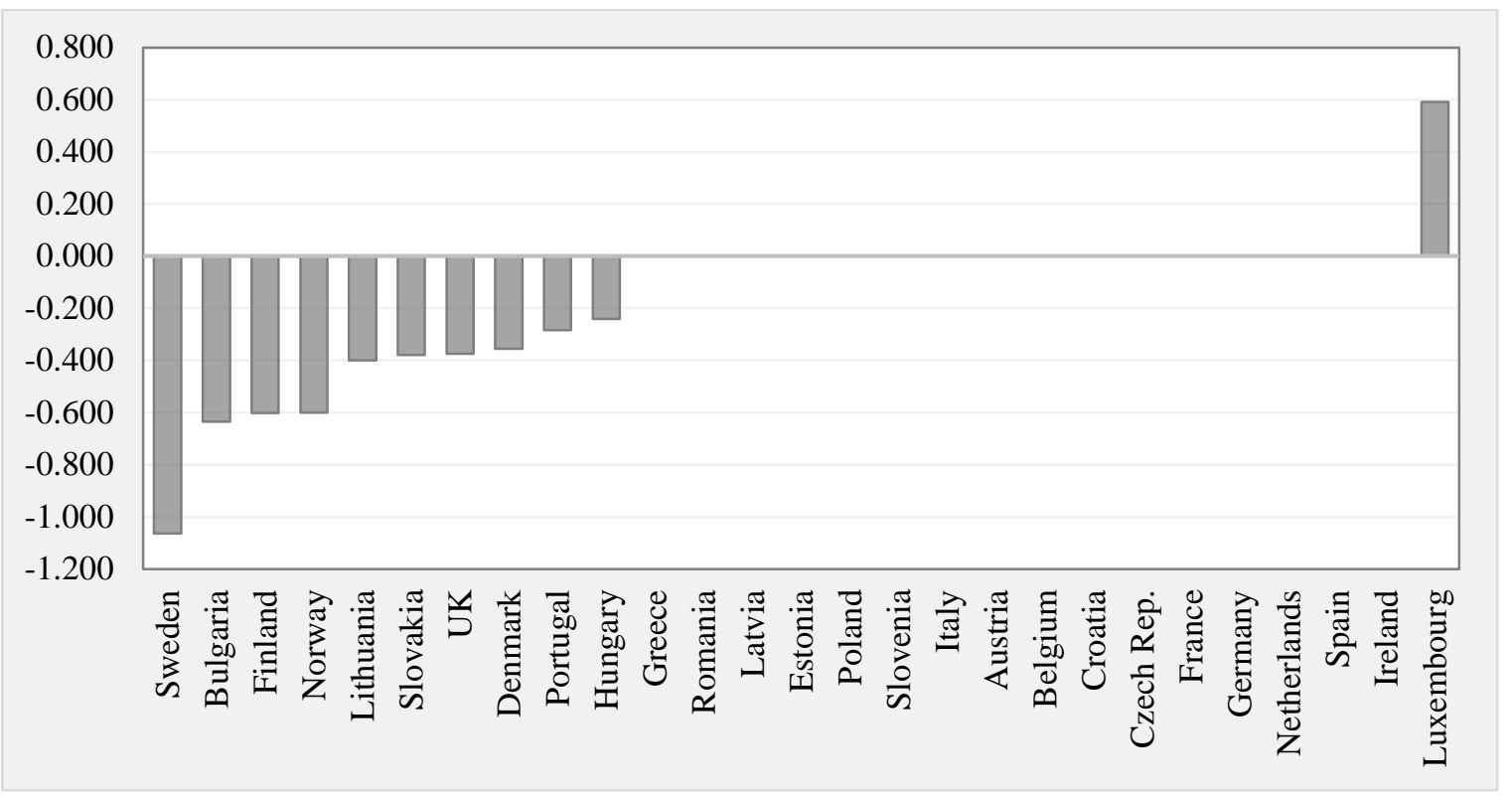

Anmerkung: In Griechenland, Rumänien, Lettland, Estland, Polen, Slowenien, Italien, Österreich, Belgien, Kroatien, Tschechien, Frankreich, Deutschland, Spanien, Niederlande und Irland waren die Abweichungen vom erwartbaren Energieverbrauch null.

Quelle: A. Thonipara, P. Runst, K. Bizer, C. Ochsner: The Energy Efficiency of Residential Buildings

Eine Analyse der klimapolitischen Gesetzgebung in Schweden und Finnland ergibt, dass beide Länder sehr ähnliche Rahmenbedingungen aufweisen, beispielsweise in den energetischen Richtlinien im Gebäudebau oder der Art und Nutzung des Fernwärmenetzes. Weshalb ist der Energieverbrauch in Schweden dennoch geringer als in Finnland? Laut der Studien zeigt sich der größte Unterschied zwischen den Ländern aufgrund der Einführung und starken Erhöhung der $\mathrm{CO}_{2}$-Steuer in Schweden. Es kann vermutet werden, dass dieser institutionelle Unterschied ein wesentlicher Treiber des niedrigeren Energieverbrauchs in Schweden (im Vergleich zu Finnland) darstellt. Die Entwicklung der Steuerhöhe stimmt mit dem Muster der sinkenden $\mathrm{CO}_{2}$-Emissionen überein (vgl. Abbildung 2). Außerdem zeigen die Autoren, dass die Entwicklung der Steuer grafisch mit der Entwicklung von Wärmepumpen korrespondiert, welche fossile Heizsysteme weitestgehend vom Markt verdrängten (siehe Abbildung 2). 
Abbildung 2: Entwicklung der $\mathrm{CO}_{2}$-Besteuerung, der Emissionen und des Verkaufs von Wärmepumpen

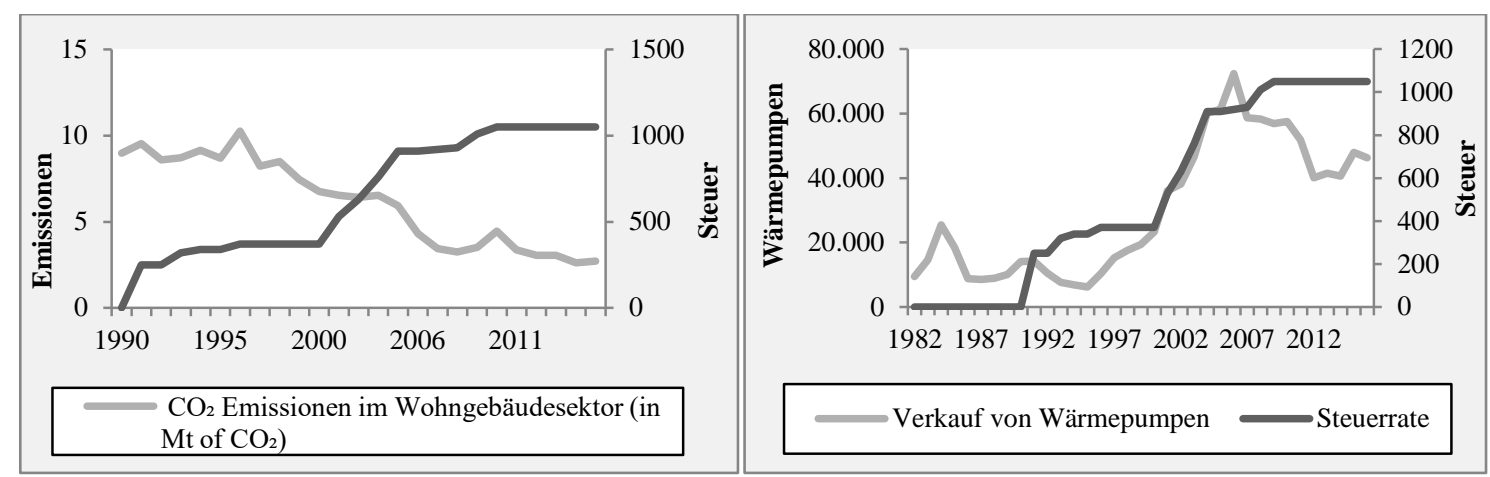

Quellen: Wärmepumpen: Svenska Kyl \& Värmepump Föreningen; $\mathrm{CO}_{2}$-Steuersätze: H. Hammar, S. Åkerfeldt: CO2-Taxation in Sweden 20 Years of Experience and Looking Ahead, 2012; $\boldsymbol{C O}_{2}$-Emissionen: Odyssee-Mure Datenbank

\section{Wohngebäude-Emissionen: empirische Analyse}

Runst \& Thonipara bauen auf dieser qualitativen Vorgängerstudie auf, indem sie die Entwicklung der Wohngebäude-Emissionen im europäischen Ländervergleich quantitativ untersuchen. ${ }^{7}$ Die Autoren nutzen synthetische Kontroll-Methoden, welche nach Ländern suchen, deren gewichtete Wohngebäudeemissionen zwischen 1990 und 2001 den schwedischen Emissionen sowie den erklärenden Faktoren (Einkommen, Ölpreis, Strompreis, Klima) entsprechen. Die gewichteten Emissionen dieser Länder ergeben ein künstlich generiertes Schweden ohne $\mathrm{CO}_{2}$-Steuer (eine synthetische Kontrollgruppe). Vergleicht man nun die Emissionsentwicklung zwischen dem künstlich generierten Schweden (ohne Steuer) und dem tatsächlichen Schweden (mit $\mathrm{CO}_{2}$-Steuer), müssten sich ab 2001 Abweichungen in den Emissionen ergeben, wenn die Steuer wirksam ist. Zwar bestand die schwedische $\mathrm{CO}_{2}$-Steuer bereits in den 1990er Jahren, aber die Höhe der Steuer wurde im Jahr 2001 stark angehoben, sodass die Folgen besonders ab diesem Jahr messbar sein sollten.

In Abbildung 3 wird die Entwicklung der Wohngebäude-Emissionen der synthetischen Kontrollgruppe und Schweden dargestellt. Der Minimierungsalgorithmus funktioniert offenbar gut, da der Abstand zwischen Schweden und der Kontrollgruppe zwischen 1990 und 2000 sehr klein ist. In der Basisspezifikation besteht das synthetische Schweden aus den Ländern Dänemark, Norwegen und Polen.

\footnotetext{
${ }^{7}$ P. Runst, A. Thonipara: Why the Scope of the Carbon Tax Matters Evidence from the Swedish Residential Sector, USAEE Working Paper, Nr. 19-416, 2019.
} 


\section{Abbildung 3: $\mathrm{CO}_{2}$-Emissionen in Schweden und einer künstlich generierten Kontrollgruppe}

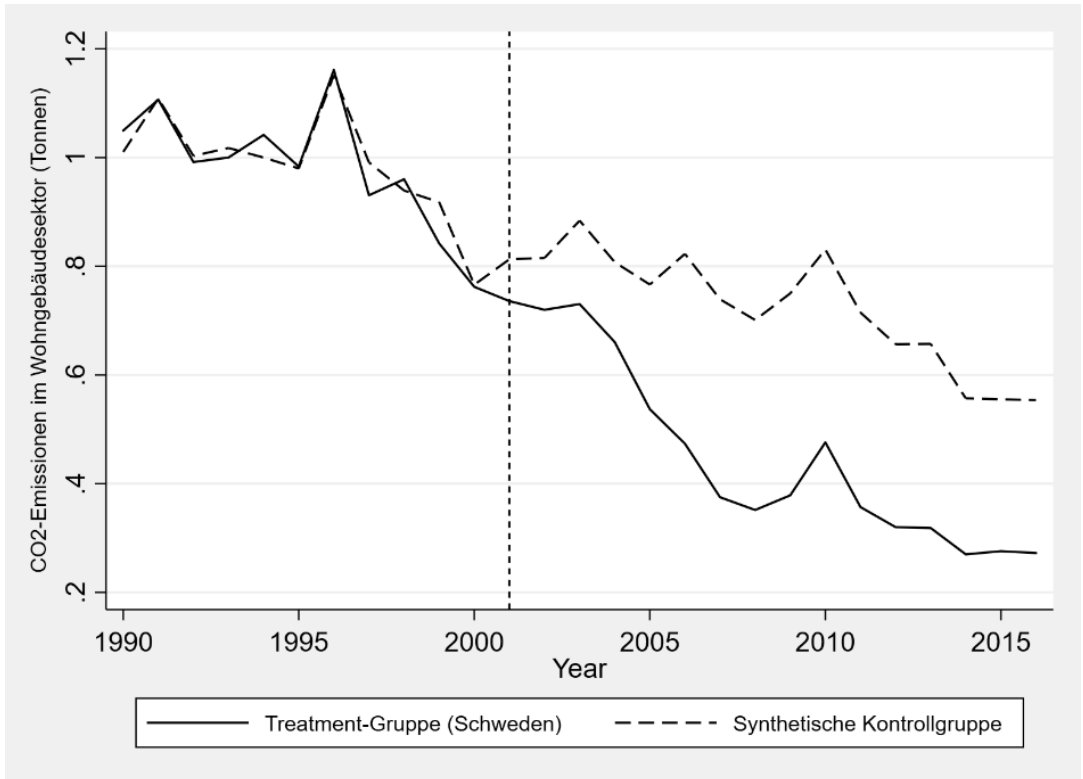

Anmerkungen: Es wurden weitere Kontrollvariablen (BIP, Energiepreise etc.) einbezogen, um zu gewährleisten, dass die gewichtete Gruppe von Ländern, welche die synthetische Kontrollgruppe bilden, viele Ähnlichkeiten mit Schweden aufweisen.

Quelle: P. Runst, A. Thonipara: Why the Scope of the Carbon Tax Matters - Evidence from the Swedish Residential Sector, USAEE Working Paper, Nr. 19-416, 2019.

Nach 2002 spreizt sich die Emissionsentwicklung. Der Abstand zwischen den Linien verdeutlicht, dass die $\mathrm{CO}_{2}$-Besteuerung die Emissionen um ca. $400 \mathrm{~kg} \mathrm{CO}$ pro Kopf und Jahr senkte. Bei einem durchschnittlichen $\mathrm{CO}_{2}$-Emissionsausstoß von rund 1,5 t $\mathrm{CO}_{2}$ pro Kopf und Jahr im Wohngebäudesektor (nach Odyssee-Mure-Daten) deuten die Ergebnisse auf einen recht starken Effekt der Besteuerung hin. ${ }^{8}$ Die Ergebnisse zeigen außerdem, dass im Vergleich zu europäischen Ländern, die noch keine $\mathrm{CO}_{2}$-Steuer implementiert haben, der EinsparungsEffekt auf bis zu $800 \mathrm{~kg} \mathrm{CO} 2$ pro Kopf und Jahr steigt. Im Vergleich zu Ländern, die bereits eine niedrigere $\mathrm{CO}_{2}$-Steuer implementiert haben, liegen die Einsparungen bei rund $350 \mathrm{~kg}$ $\mathrm{CO}_{2}$ pro Kopf und Jahr. Die Höhe der $\mathrm{CO}_{2}$-Steuer ist also entscheidend für ihre Wirksamkeit. Weitere Spezifikationen (Länder-Placebos, In-time-Placebos, verschiedene Samples) verdeutlichen die Robustheit der Ergebnisse.

\footnotetext{
${ }^{8}$ Es werden insgesamt drei Samples genutzt: Neben dem Sample 1, das alle Länder einschließt, werden in Sample 2 nur Länder ohne eine $\mathrm{CO}_{2}$-Steuer und ohne eine starke Energiesteuererhöhung als Kontrollgruppe genutzt, und in Sample 3 nur Länder mit einer bereits implementierten $\mathrm{CO}_{2}$-Steuer $\left(\mathrm{CO}_{2}\right.$-Steuersatz über 20 Euro).
} 
Alle empirischen Untersuchungen, die kausale Effekte untersuchen, müssen so gut wie möglich versuchen, alternative Erklärungen auszuschließen, welche ebenfalls für den beobachteten Effekt -die relative Verminderung der Emissionen- verantwortlich sein könnten. Runst und Thonipara listen einige klimapolitische Maßnahmen, welche in Schweden durchgeführt wurden, auf und schlussfolgern, dass die meisten dieser Instrumente nicht als alternative Erklärungen infrage kommen, entweder, weil die zeitliche Dimension nicht passt (Implementierung zu früh oder zu spät) oder die zu erwartenden Effekte zu gering ausfallen. Hingegen gibt es zwei besonders plausible Alternativ-Erklärungen, die gesondert betrachtet werden: die schwedische Atomenergienutzung, welche einen Übergang zu elektrisch betriebenen Wärmepumpen begünstigen könnte und eine Transformation des Fernwärmesystems von Öl- und Kohle-basierten Energieträgern zu Biomasse und Abfall. Während der Anteil der Haushalte mit Wärmenetzwerkanbindung in die quantitative Untersuchung einfließt und sich die Ergebnisse nicht ändern, stellt die Atomstromversorgung eine größere potenzielle Herausforderung dar. Es kann allerdings gezeigt werden, dass die Strompreise (bereinigt nach Kaufkraft) in Schweden in keinem der relevanten Jahre unter dem europäischen Durchschnitt lagen. Im Gegenteil, besonders nach 2001 steigen die Strompreise und liegen im oberen Drittel der europäischen Strompreisverteilung. Damit können niedrigere, durch Atomenergie getriebene Strompreise nicht als Erklärung für den Umstieg auf Wärmepumpen gelten.

\section{Schlussfolgerungen}

Kausale Zusammenhänge können natürlich nie zweifelsfrei empirisch bewiesen werden. Die Hinweise aus den zwei vorliegenden Studien verdichten sich aber soweit, dass die Vermutung über einen kausalen Einfluss der $\mathrm{CO}_{2}$-Besteuerung auf die Verminderung der Emissionen mit einem gewissen Maße an Zuversicht geäußert werden darf. Im Zusammenhang mit den theoretischen Vorzügen einer marktwirtschaftlichen Lösung (Zertifikatehandel oder Besteuerung), der Technologieoffenheit, Kostenminimierung, und dem Verursacherprinzip, sowie der mangelnden Wirkung bisheriger ordnungspolitischer Maßnahmen, ergeben sich laut den Ergebnissen der vorgestellten Studien Anstöße für eine Weiterentwicklung und Umgestaltung der deutschen Klimapolitik. Der Abbau direkter staatlicher Vorgaben, Verbote und Subventionen zugunsten einer $\mathrm{CO}_{2}$-Besteuerung oder des Ausbaus des Zertifikatehandels hätte den zusätzlichen Vorteil der Verminderung bürokratischer Komplexität und der daraus resultierenden Kosten. 


\section{Chapter V}

\section{$\mathrm{CO}_{2}$-Bepreisungen in Handwerksunternehmen: Ökonomische Szenarien zu Kostenwirkung und Anpassungsreaktionen}

With Petrik Runst, Felix Röben

\section{Published in:}

Göttinger Beiträge zur Handwerksforschung (Heft 28). Göttingen. 


\section{$\mathrm{CO}_{2}$-Bepreisungen in Handwerksunternehmen - Ökonomische Szenarien zu Kosten- wirkung und Anpassungsreaktionen}

Autoren: Petrik Runst, Anita Thonipara, Felix Röben

Mit Unterstützung der Mitarbeiter der Mittelstandsinitiative Energiewende und Klimaschutz (MIE)

Göttinger Beiträge zur Handwerksforschung Nr. 28

\section{Zusammenfassung}

- Die Mehrkostenbelastung durch eine $\mathrm{CO}_{2}$-Bepreisung von 40, 60 bzw. 120 Euro pro Tonne verursacht - ungeachtet des konkreten Bepreisungsinstruments (Mengensteuerung mit Zertifikatehandel, Abgaben- oder Steuerlösung) in den sieben ausgewählten Handwerkszweigen sehr unterschiedliche Mehrkosten aufgrund der heterogenen Betriebsstrukturen und Arbeitsweisen in den verschiedenen Handwerkszweigen.

- Dabei belaufen sich die Mehrkosten durchschnittlich (über alle Unternehmen und Handwerkszweige hinweg) auf ca. 150 Euro pro Mitarbeiter und Jahr (bei $60 €$ / t) bzw. 300 Euro pro Mitarbeiter und Jahr (bei $120 € / \mathrm{t}$ ).

- Größere Unternehmen werden prinzipiell weniger stark getroffen als kleinere Unternehmen, da sie tendenziell energieeffizienter arbeiten.

- Eine Abschaffung der EEG-Umlage würde die Einführung einer $\mathrm{CO}_{2}$-Bepreisung von 60/ 120 Euro pro Tonne nahezu bis vollständig kompensieren, d.h. es ergäben sich in der kurzen Frist kaum Mehrkosten für die Handwerksunternehmen im Falle einer $\mathrm{CO}_{2}$-Bepreisung bei gleichzeitiger Streichung der EEG-Umlage.

- Ohne entsprechende Kompensation der $\mathrm{CO}_{2}$-Mehrkosten durch die Streichung der EEGUmlage oder andere Instrumente wie z.B. eine Pauschalzahlung nach Schweizer Vorbild ist davon auszugehen, dass Handwerksunternehmen Anpassungsmaßnahmen durchführen, um die Mehrkosten zu reduzieren. Zwei wesentliche Anpassungskanäle wurden untersucht Energieeffizienzmaßnahmen und die Ersetzung $\mathrm{CO}_{2}$-intensiver Energieträger. 
- Kurzfristig, d.h. innerhalb von ca. 4 Jahren, können die untersuchten Maßnahmen die $\mathrm{CO}_{2}$ Emissionen - und damit die Mehrkosten - der Unternehmen zwar teilweise senken während die Investitionskosten recht hoch ausfallen, sodass davon ausgegangen werden kann, dass nur wenige Anpassungsmaßnahmen vollzogen werden.

Schlagwörter: $\mathrm{CO}_{2}$-Bepreisung, Kostenschätzung, Handwerksunternehmen, Handwerk 


\section{Impact Evaluation - $\mathrm{CO}_{2}$-Pricing and Additional Costs in Crafts Companies}

Authors: Petrik Runst, Anita Thonipara, Felix Röben

and support by Mittelstandsinitiative Energiewende und Klimaschutz

Göttinger Beiträge zur Handwerksforschung Nr. 28

\section{Executive Summary}

- $\mathrm{CO}_{2}$-prices of 40, 60 or 120 Euros per ton of $\mathrm{CO}_{2}$ will translate into very heterogeneous cost increases in crafts companies, depending on the nature of the respective businesses.

- The average cost increases amount to 150 Euros per employee and year (at a $\mathrm{CO}_{2}$ price of 60 Euros) or 300 Euros per employee and year (at a $\mathrm{CO}_{2}$ price of 120 Euros).

- Larger companies have a tendency to be comparatively more energy efficient and will therefore be less affected.

- Considering a $\mathrm{CO}_{2}$-price of 60 Euros per ton, abolishing the EEG-surcharge on electricity would lead to a virtually complete compensation of the additional $\mathrm{CO}_{2}$-related costs. At 120 Euros, the additional costs for crafts companies would still be significantly reduced.

- Without such a compensatory measure, crafts companies will bear the full burden of the price increase. In order to reduce these $\mathrm{CO}_{2}$-related costs, a variety of adjustment measures may be implemented, two of which were examined here: energy-efficiency measures and the substitution of $\mathrm{CO}_{2}$-intensive energy carriers.

- In the short term (1 to 4 years), none of the examined measures will be able to reduce $\mathrm{CO}_{2}$ emissions (and thereby costs) in a significant manner while investment costs are high. Thus, we expect only few measures to be implemented within crafts businesses in the short term.

Keywords: carbon-pricing, cost estimation, crafts companies, impact evaluation 


\section{Einleitung und Untersuchungsziel}

Da absehbar ist, dass die kurz- und mittelfristigen Klimaziele der deutschen Bundesregierung verfehlt werden, stellt sich zunehmend die Frage, ob die deutsche Klimapolitik grundlegenden Veränderungen unterzogen werden sollte. In den vergangenen Jahren zeigte sich, dass regulatorische Instrumente, welche direkt in die Märkte eingreifen und konkrete Verhaltensweisen vorschreiben (Bsp. Gebäudestandards), diese subventionieren oder untersagen, die angestrebten Ziele in einigen Fällen verfehlt haben (siehe Runst, 2016; Feser et al., 2015). Direkte Staatseingriffe dieser Art, welche dem oft genannten Kriterium der Technologieoffenheit nicht genügen, stellen sehr hohe informatorische Anforderungen an die Regulierer, welche die Gesetze und Verordnungen entwickeln und in den politischen Prozess einbringen. Die Experten müssen schließlich die komplexen gesellschaftlichen Zusammenhänge gut genug überblicken, um die Entscheidung zu rechtfertigen, konkrete Technologien exklusiv zu fördern bzw. bestimmte Verhaltensweisen zu sanktionieren. Außerdem werden direkte staatliche Instrumente der dynamischen Struktur einer Gesellschaft und Volkswirtschaft oft nicht gerecht. Sie müssten im Zeitablauf immer wieder an die veränderten Realitäten angepasst werden, wodurch sich die informatorischen Anforderungen an den Gesetzgeber noch weiter erhöhen. Schließlich ist effektive Klimapolitik nicht mit effizienter Klimapolitik gleichzusetzen. Dabei sollte es stets das Ziel sein, die Ausgaben pro vermiedener Tonne $\mathrm{CO}_{2} \mathrm{zu}$ minimieren, denn auch eine effektive Klimapolitik kann bei zu hoher Kostenbelastung dazu führen, dass der politische Rückhalt für klimapolitische Maßnahmen in der Bevölkerung zurückgeht.

Die aktuell diskutierte Möglichkeit einer $\mathrm{CO}_{2}$-Bepreisung wird von der Mehrheit der Energieökonomen (75\%) als erfolgversprechendes klimapolitisches Instrument gesehen. ${ }^{1}$ Der Zertifikate-Handel, die Erhebung einer spezifischen Abgabe oder die direkte Besteuerung von Emissionen stellen dabei die drei wichtigsten Instrumente der $\mathrm{CO}_{2}$-Bepreisung dar. Als Instrument einer marktbasierten Politik stellt die $\mathrm{CO}_{2}$-Bepreisung deutlich niedrigere informatorische Anforderungen an den Gesetzgeber im Vergleich zu direkten Eingriffen des Staates in der Form von Geboten und Verboten. Die Grundidee basiert auf einer Verteuerung von Gütern (vorrangig Brennstoffe) gemäß ihrer $\mathrm{CO}_{2}$-Emission (welche einmalig festgelegt werden müssen). Den Wirtschaftssubjekten bleibt es im Folgenden selbst überlassen, auf welche Weise sie die dadurch entstehenden Zusatzkosten mindern und dadurch zum Klimaschutz beitragen. Marktbasierte Ansätze genügen dem Gebot der Technologieoffenheit, weil keine konkreten Ge- oder Verbote gesetzt werden. Außerdem ergibt sich durch Bepreisung ein klarer dy-

\footnotetext{
${ }^{1}$ Howard \& Sylvan (2015).
} 
namischer Vorteil: Direkte Eingriffe, welche konkrete Handlungsweisen/Technologien fördern oder verbieten, müssen im Idealfall an die sich ständig verändernde Realität angepasst werden. Im Gegensatz dazu basiert ein wesentlicher Vorteil von marktbasierten Instrumenten darauf, dass die sich ändernden Realitäten (Technologien, Preise, Einkommen etc.) von den Wirtschaftssubjekten selbst aufgegriffen werden, welche danach streben ihre $\mathrm{CO}_{2}$-bezogenen Kosten zu verringern.

In Form des European Emission Trading System (ETS) findet die marktbasierte Klimapolitik in Deutschland durch die Bepreisung der Emissionen von Großunternehmen bereits Anwendung, darunter auch im Stromerzeugungssektor. Die aktuelle politische Debatte kreist nun darum, die Wirtschaftsbereiche, welche nicht vom ETS erfasst sind, ebenfalls einzubeziehen, da die bisherigen direkten Eingriffe nur wenig Erfolg zeigten und vergleichsweise kostenintensiver sind als marktbasierte Instrumente. Beispielsweise hat sich die Sanierungsrate in Deutschland in den letzten Jahren kaum erhöht. ${ }^{2}$

Eine weitere $\mathrm{CO}_{2}$-Bepreisung sollte dabei nicht als Instrument zur Erhöhung von Staatseinnahmen verstanden werden. Stattdessen sollte es das primäre Ziel sein, Handlungsänderungen der Wirtschaftssubjekte zu befördern, dadurch Emissionen zu senken, ohne aber das Ziel zu verfolgen, das Budgetaufkommen zu erhöhen. Das heißt, eine zusätzliche $\mathrm{CO}_{2}$-Bepreisung sollte fiskalisch neutral wirken. Diesem Ziel kann man auf unterschiedlichen Weisen gerecht werden. Unter anderem könnten die gesamten Einnahmen an alle deutschen Privatpersonen zurückgezahlt werden, beispielsweise über die Einkommenssteuererklärung; für Unternehmen könnte sich nach Schweizer Vorbild die Rückzahlung an den Lohnkosten orientieren. Alternativ könnte das Erneuerbare-Energien-Gesetz (EEG) entfallen und stattdessen die bestehenden Zahlungsverpflichtungen gegenüber den Erzeugern erneuerbarer Energie durch die $\mathrm{CO}_{2}$ Bepreisungs-Einnahmen abgedeckt werden. Damit entfiele die EEG-Umlage für Privatpersonen und Unternehmen. In der im Folgenden beschriebenen Kostenabschätzung werden wir u.a. dieses Szenario untersuchen. Alternativ oder ergänzend hierzu wären z.B. auch die Reduktion von Sozialabgaben oder die Reduzierung der Energiebesteuerung auf das EUMindestmaß möglich.

Die Wirksamkeit der 1990 in Schweden eingeführten und in Folge sukzessive deutlich erhöhten $\mathrm{CO}_{2}$-Steuer ${ }^{3}$ wurde erstmalig wissenschaftlich untersucht (Thonipara et al., 2019). Die

\footnotetext{
${ }^{2}$ Vgl. Runst (2016).

3 Auch wenn hier auf eine $\mathrm{CO}_{2}$-Besteuerung Bezug genommen wird, haben auch die beiden genannten Alternativen Preis- und damit Steuerungseffekte. Der zentrale Unterschied zwischen Mengensteuerung mittels Zertifikatehandel einerseits und Steuer bzw. Abgabe andererseits ist, dass sich der Preis bei Mengensteuerung in
} 
bislang vorliegenden Ergebnisse deuten darauf hin, dass das Instrument dazu beitrug, den Energieverbrauch im Wohngebäudesektor deutlich zu reduzieren. Außerdem zeigt sich, dass die im Wohngebäudesektor verursachten Emissionen ebenfalls sinken und dass diese Entwicklung als kausale Folge der $\mathrm{CO}_{2}$-Bepreisung zu sehen ist (Runst \& Thonipara, 2019). Aufgrund der genannten theoretischen Vorteile und der empirisch gezeigten Wirksamkeit einer $\mathrm{CO}_{2}$-Bepreisung kann angenommen werden, dass deren Einführung auch in Deutschland positive Effekte auf die Erreichung der Klimaschutzziele haben würde.

Der hier vorliegende Beitrag befasst sich mit einer Abschätzung der Kosteneffekte einer zusätzlichen $\mathrm{CO}_{2}$-Bepreisung auf Handwerksunternehmen. Grundlegend sind solche Abschätzungen immer mit Annahmen und daraus resultierenden Unschärfen verbunden, da es sich nicht um die wissenschaftliche Wirkungsuntersuchung von bereits getätigten politischen Interventionen handelt. Nichtsdestoweniger sind die Annahmen der hier vorgenommenen Kostenabschätzungen fundiert und in akzeptablem Maß präzise, so dass die Ergebnisse als heuristische Grundlage einer handwerkspolitischen Debatte genutzt werden können. Eine grundlegende Einschränkung betrifft den Mobilitätssektor, der aufgrund bisher nicht hinreichender Datengrundlage aus der Untersuchung ausgeklammert wurde. Dadurch werden die in diesem Bereich anfallenden Mehrkosten nicht berücksichtig, was zu einer tendenziellen Unterschätzung der Mehrkostenbelastung einer $\mathrm{CO}_{2}$-Bepreisung führt.

Die Studie ist in zwei Teile untergliedert. Zunächst werden die zusätzlichen unternehmerischen Kosten berechnet, welche in verschiedenen Politik-Szenarien aufkämen. Dabei werden zum einen unterschiedliche $\mathrm{CO}_{2}$-Preise (40, 60 und 120 Euro pro Tonne) und Kompensationsszenarien (Abschaffung der EEG-Umlage oder Energiesteuer) untersucht. Die Berechnungen werden für sieben energieintensive Handwerkszweige vorgenommen. In Schritt zwei werden wahrscheinliche unternehmerische Anpassungskanäle untersucht und deren Einsparpotenziale abgeschätzt.

einem Marktprozess aus den konkreten Angebots- und Nachfragebedingungen vor Ort ergibt. Diese im Marktprozess automatisch verarbeiteten Informationen können bei einer Steuer oder Abgabe lediglich - und das auch nur ausschnittsweise - abgeschätzt werden. Insoweit erfordert eine Steuer- oder Abgabenlösung ein wesentlich höheres Wissen des Gesetzgebers über die konkreten Gegebenheiten vor Ort und die dadurch induzierten Anpassungsprozesse. Eine Steuer- oder Abgabenlösung mag zwar Änderungswirkungen zeitigen und insoweit auch effektiv sein. Ob der dabei gesetzte $\mathrm{CO}_{2}$-Preis jedoch den intendierten - quantitativen - Reduktionszielen genügt, ist angesichts des benannten Informationsproblems zumindest fraglich. 


\section{Kostenschätzung}

\subsection{Datengrundlage}

Das Ziel der Studie ist es, die Kostenbelastung für Handwerksunternehmen zu berechnen, nachdem eine zusätzliche $\mathrm{CO}_{2}$-Bepreisung eingeführt wird. Im einfachsten Fall werden die $\mathrm{CO}_{2}$-Emissionen eines Unternehmens zugrunde gelegt und mit dem pro Tonnen Preis multipliziert. Um die Emission von Handwerkunternehmen zu ermitteln, werden zunächst Daten zu den Energieverbräuchen benötigt.

Im Rahmen der Mittelstandsinitiative Energiewende und Klimaschutz ${ }^{4}$ (MIE) wurden solche Verbrauchsdaten von Unternehmen in sieben energieintensiven Handwerkszweigen („Gewerken“) erhoben (Bäcker, Fleischer, Friseure, Kraftfahrzeugtechniker, Metall, Textilreiniger und Tischler). Diese Fokussierung erfolgte, weil die entsprechenden Betriebe aufgrund der vergleichsweise hohen Energieverbräuche von Effizienzmaßnahmen besonders stark profitieren können. Teilnehmende Unternehmen wurden dabei nicht MIE-seitig ausgewählt, sondern sind ihrerseits auf die MIE-Partner zugekommen. ${ }^{5}$

Die Datenaufnahme erfolgte zwischen 2014 und 2018 mit dem primären Ziel, die Energieeinsparpotenziale der betrachteten Betriebe zu eruieren und diese mittel- bis langfristig energieeffizienter aufzustellen. Dabei wurden die Daten im Rahmen von Vor-Ort-Besuchen in den betreffenden Handwerksbetrieben aufgenommen, überwiegend mittels standardisierter „Gesprächsprotokolle“. Angaben zu Energieverbräuchen wurden üblicherweise direkt den Verbrauchsrechnungen der jeweiligen Versorger entnommen; in Einzelfällen wurden Angaben auch geschätzt und/oder auf volle $100 \mathrm{kWh}$ gerundet.

Auf dieser Basis stehen für jedes berücksichtigte Unternehmen Informationen zum Energieverbrauch unterschiedlicher Energieträger, zur Anzahl der Mitarbeiter und teilweise zum Jahresumsatz zur Verfügung. Auf Grundlage dieser Energieverbräuche konnten die $\mathrm{CO}_{2}$ Emissionen jedes Unternehmens berechnet werden.

\footnotetext{
${ }^{4}$ Die Mittelstandsinitiative Energiewende und Klimaschutz ist ein von BMWi und BMU getragenes Förderprojekt, das die mittelständischen Unternehmen bei der Umsetzung der Energiewende vor Ort unterstützt; Energieeinsparpotenziale in den Betrieben sollen gehoben und ihre Energieeffizienz verbessert werden (www.mittelstand-energiewende.de).

5 Abgesehen von der Tatsache, dass sich zwangsläufig nur am Thema interessierte Unternehmen auch tatsächlich für eine Vor-Ort-Beratung mit Datenaufnahme entschieden haben, blieb durch diese Vorgehensweise die Auswahl der teilnehmenden Betriebe dem Zufall überlassen. Die Aufnahme der betrieblichen Verbrauchsdaten, die für die vorliegende Studie aggregiert wurden, war im Rahmen der Mittelstandsinitiative nicht die prioritäre Aufgabe, sondern ein Nebenprodukt.
} 


\subsection{Vorgehensweise}

Zunächst wird die Mehrbelastung der Unternehmen durch $\mathrm{CO}_{2}$-Bepreisung in drei Basisszenarien berechnet, in denen ein $\mathrm{CO}_{2}$-Preis von 40, 60 und 120 Euro pro Tonne angenommen und dieser mit den Emissionen des jeweiligen Unternehmens multipliziert wird. Die Obergrenze von 120 Euro pro Tonne begründet sich durch den $\mathrm{CO}_{2}$-Preis in Schweden, welcher aktuell den höchsten Wert weltweit darstellt. Die Emissionen, welche durch Stromverbrauch generiert werden, werden in der Berechnung außen vor gelassen, da der Stromsektor bereits dem ETS unterliegt und angenommen wird, dass keine Doppelbepreisung erfolgt. ${ }^{6}$ Wie jedoch in der Einleitung beschrieben, sollte die Einführung von $\mathrm{CO}_{2}$-Preisen fiskalisch neutral erfolgen, um die Mehrbelastung der Unternehmen zu kompensieren. ${ }^{7}$ Hierfür werden zwei mögliche Kanäle untersucht.

In Szenario I wird die umlagefinanzierte Subvention von Wind- und Solarenergie im Rahmen des EEG eingestellt, d.h. es werden keine neuen Zahlungsverpflichtungen, im Sinne garantierter Einspeisevergütungen pro KWh, eingegangen. Die bereits bestehenden langfristigen EEGZahlungsverpflichtungen wären zukünftig durch das Aufkommen aus der $\mathrm{CO}_{2}$-Bepreisung gedeckt bis diese auslaufen. Laut Schätzungen des Bundesministeriums für Wirtschaft und Energie $^{8}$ steigt das Gesamtaufkommen durch das EEG von 30 Mrd. Euro im Jahr 2017 auf 33 Mrd. Euro im Jahr 2019. Um diese 33 Mrd. Euro zu kompensieren, würde ein $\mathrm{CO}_{2}$-Preis von ca. 70 Euro pro Tonne ausreichen ${ }^{9}$, d.h. die vollständige Finanzierung der bereits eingegangenen EEG-Subventionsverpflichtungen wäre bei einem $\mathrm{CO}_{2}$-Preis von 70 Euro pro Tonne möglich.

In Szenario II wird die traditionelle Energiesteuer - das jährliche Energiesteueraufkommen beläuft sich auf ca. $42 \mathrm{Mrd}$. - ganz oder teilweise durch eine $\mathrm{CO}_{2}$-Bepreisung ersetzt. Die Belastung aus der bestehenden Energiesteuer der Unternehmen wird berechnet, indem die Verbräuche der einzelnen Energieträger (in kWh) mit den Energiesteuerraten multipliziert wer-

\footnotetext{
${ }^{6}$ Der ETS stellt ebenfalls eine Form der $\mathrm{CO}_{2}$-Bepreisung dar. Durch die jährliche zusätzliche Verknappung der Zertifikate soll die Gesamtzertifikatmenge (Emissionsmenge) bis 2030 um 43 \% sinken (Vgl. mit 2005).

7 Trotz der fiskalisch neutralen Ausgestaltung, würde der $\mathrm{CO}_{2}$-Preis seine Lenkungswirkung entfalten. Die Rückerstattung der gesamten Einnahmen an alle Personen und Unternehmen ist unabhängig vom eigenen Verbrauch, der zu zahlende $\mathrm{CO}_{2}$ Preis ist hingegen vom eigenen Verbrauchsverhalten bestimmt. D.h. eine Privatperson, die wenig $\mathrm{CO}_{2}$ verbraucht trägt geringe Kosten und erhält durch die Rückerstattung einen gewissen Betrag. Wer viel $\mathrm{CO}_{2}$ emittiert, trägt höhere Kosten und erhält den gleichen Betrag wie der Niedrigverbraucher. Am Ende werden niedrige Emissionen belohnt und hohe Emissionen bestraft.

${ }^{8}$ BMWI (2018). EEG in Zahlen: Vergütungen, Differenzkosten und EEG-Umlage 2000 bis 2019.

${ }^{9}$ Wenn die $\mathrm{CO}_{2}$-Bepreisung keine kurzfristigen Substitutionsmechanismen auslöst, schätzen wir das $\mathrm{CO}_{2}$ Steueraufkommen bei einem Preis von 70 Euro pro Tonne auf ca. 38 Mrd. Euro. Substitution beschreibt den Prozess, in dem Nutzer von $\mathrm{CO}_{2}$-intensiven (Bsp. Öl) auf weniger $\mathrm{CO}_{2}$-intensive Energiequellen (Bsp. Wärmepumpen) umsteigen.
} 
den. Dabei wurde die Brennstoffzusammensetzung von Fernwärme auf Basis einer Analyse des Energieeffizienzverbands für Wärme, Kälte und KWK e.V. geschätzt. ${ }^{10}$ Schließlich wird in Szenario II die Energiesteuerbelastung von dem $\mathrm{CO}_{2}$-Preis abgezogen. Szenario IIa nutzt hierzu einen $\mathrm{CO}_{2}$-Preis von 120 Euro abzüglich der gesamten Energiesteuer, während Szenario IIb einen $\mathrm{CO}_{2}$-Preis in Höhe von 60 Euro mit einer teilweisen (50 prozentigen) Energiesteuerentlastung kombiniert. ${ }^{11}$ Tabelle 2 fasst die bisherige Energiebesteuerung, die $\mathrm{CO}_{2^{-}}$ Abgabe, sowie die $\mathrm{CO}_{2}$-Emissionen je Energieträger zusammen.

Tabelle 1: $\quad$ Übersicht aller Annahmen

\begin{tabular}{|ll} 
Allgemein & $\begin{array}{l}\text { Energiequellen, die bereits dem ETS unterliegen (bsp. Strom), } \\
\text { werden nicht doppelt belastet. }\end{array}$ \\
CO & \\
& Der Preis je Tonne $\mathrm{CO}_{2}$ beträgt maximal 120 Euro. \\
Fiskalische & Durchschnitt). Die zusätzlichen Kosten werden entweder durch $\mathrm{CO}_{2}$-Bepreisung wird aufkommensneutral ausgestaltet (im \\
Neutralität & die Abschaffung der EEG-Umlage oder der Reduzierung der \\
EEG-Abgaben & Energiesteuer auf das EU-Minimum kompensiert. \\
(2025) & 7,8 Cent pro kWh. Schätzung des IW-Köln.
\end{tabular}

Um die Kostenbelastung der Unternehmen in beiden Szenarien zu berechnen, müssen eine Reihe von Annahmen getroffen werden, welche in Tabelle 1 zusammenfassend dargestellt werden. In Szenario I wird eine EEG Abgabe von 7,8 Cent pro kWh zugrunde gelegt, welche auf einer Schätzung des IW Köln für das Jahr 2025 beruht. ${ }^{12}$ Durch die Multiplikation der EEG-Abgabe mit dem Stromverbrauch ergibt sich die kompensatorische Einsparung für den Betrieb, welche von der Belastung durch die $\mathrm{CO}_{2}$-Abgabe abgezogen wird.

\footnotetext{
10 AGFW - Hauptbericht, 2017.

11 Diese Vorgehensweise wurde in Schweden gewählt.

12 Kremheller, Antonia; Schaefer, Thilo (2018).
} 
Tabelle 2: Steuerbelastung einzelner Energieträger nach EnergieStG, Emissionen und Mehrbelastung durch $\mathrm{CO}_{2}$-Bepreisung

\begin{tabular}{|l|l|l|l|}
\hline Energieträger & $\begin{array}{l}\text { Energiesteuer (Cent } \\
\text { pro } \mathbf{k W h})\end{array}$ & $\begin{array}{l}\mathbf{g C O}_{2} \text { Emission je } \\
\mathbf{k W h}\end{array}$ & $\begin{array}{l}\mathbf{C O}_{2} \text {-Preis } \\
\mathbf{1 2 0} € / \mathbf{t C O}_{2} \quad \text { Szenario } \\
\text { (Cent pro } \mathbf{k W h} \text { ) }\end{array}$ \\
\hline Heizöl & 1,19 & 312 & 3,74 \\
\hline Gas & 1,39 & 248 & 2,98 \\
\hline Strom & 2,05 & 593 & 0 \\
\hline Kohle & 12 & 415 & 17 \\
\hline Fernwärme & 5,39 & 317 & 3,80 \\
\hline
\end{tabular}

Anmerkung: Die $\mathrm{CO}_{2}$-Emissionsfaktoren basieren auf BAFA (2016) "Energieberatungen im Mittelstand - Merkblatt für die Erstellung eines Beratungsberichts“ vom 21.07.2016.

\subsection{Ergebnisse - Mehrkostenbelastung vor betrieblicher Anpassung}

Durch die im vorherigen Abschnitt erläuterte Vorgehensweise ergeben sich die in Tabelle 3 dargestellten durchschnittlichen Kostenbelastungen pro Mitarbeiter. Die Darstellung erfolgt pro Mitarbeiter, da eine bessere Vergleichbarkeit und Anwendbarkeit der Ergebnisse auf unterschiedliche Unternehmen möglich ist. Eine vereinfachte Darstellung zum Zwecke der Übersichtlichkeit erfolgt in 6. Anhang Tabelle 11.

Die Matrix ist in die sieben in die Analyse einbezogenen Handwerkszweige untergliedert. Für jeden Handwerkszweig wird die durchschnittliche Kostenbelastung für alle Unternehmen im Datensatz sowie für kleinere und größere Unternehmen getrennt ausgewiesen. Spalten 1 bis 3 stellen die Belastungen für drei verschiedene $\mathrm{CO}_{2}$-Preise dar (40, 60 und 120 Euro pro Tonne). In Spalte 4 und 5 werden von der Grundbelastung durch die $\mathrm{CO}_{2}$-Bepreisung die EEGUmlage abgezogen. In Spalte 6 wurde die geschätzte Energiesteuerbelastung des Betriebs von der Grundbelastung durch $\mathrm{CO}_{2}$-Bepreisung abgezogen. In Spalte 7 wird angenommen, dass nur die Hälfte der Energiesteuer anfällt, während der $\mathrm{CO}_{2}$-Preis 60 Euro pro Tonne beträgt.

Betrachtet man das Basisszenario, fällt zunächst auf, dass, mit Ausnahme der Fleischer, kleinere Unternehmen stärker belastet sind als größere Unternehmen, da letztere vermutlich energieeffizienter arbeiten und dadurch weniger stark von einer $\mathrm{CO}_{2}$-Bepreisung betroffen sind. Je nach Ausprägung des $\mathrm{CO}_{2}$-Preises ergeben sich Mehrbelastungen zwischen 7 und 1.577 Euro pro Mitarbeiter und Jahr. Handwerksunternehmen wären aufgrund ihrer heterogenen Struktur also sehr unterschiedlich belastet. Bei einem $\mathrm{CO}_{2}$-Preis von 60 Euro pro Tonne läge die 
durchschnittliche Mehrbelastung der Mittelwertunternehmen (definiert als ein Unternehmen, das die durchschnittlichen Werte aller im Datensatz befindlichen Unternehmen aufweist) bei 154 Euro pro Jahr und Mitarbeiter.

Weiterhin wird in Szenario Ia und Ib deutlich, dass sich die Befreiung von der EEG-Umlage für die Handwerksunternehmen stark positiv auswirkt. Dadurch ergibt sich der unerwartete Befund, dass Unternehmen in den betrachteten sieben Handwerkszweigen bei einem $\mathrm{CO}_{2}$ Preis von 60 Euro pro Tonne und der Abschaffung der EEG-Abgabe finanziell bessergestellt wären. Dies ergibt sich daraus, dass die EEG-Abgabe deutlich höher ausfällt als die $\mathrm{CO}_{2}$ Preisbelastung. Erst ab einem $\mathrm{CO}_{2}$-Preis von 120 Euro pro Tonne ergibt sich eine Mehrbelastung für einige Unternehmen. Von kleineren Kfz- und Textilreinigerunternehmen abgesehen, fallen diese Mehrbelastungen jedoch auch in diesem Szenario gering aus.

In den letzten beiden Spalten zeigt sich, dass die Ersetzung der Energiebesteuerung durch eine $\mathrm{CO}_{2}$-basierte Abgabe in den meisten Fällen Mehrbelastungen auslöst und diese höher sind als in Szenario I (Abschaffung des EEG). In den meisten Fällen läge die Mehrbelastung aber auch hier unter 100 Euro pro Mitarbeiter und Jahr. 
Tabelle 3: Geschätzte jährliche Kostenbelastung der Unternehmen durch $\mathrm{CO}_{2}$-Bepreisung (pro Mitarbeiter, in €)

\begin{tabular}{|c|c|c|c|c|c|c|c|c|c|}
\hline & & $\begin{array}{l}\text { Mitarbei- } \\
\text { ter je Un- }\end{array}$ & & $\begin{array}{l}\text { sszen } \\
{ }_{2}-P r\end{array}$ & rio & $\begin{array}{c}\text { Ia } \\
\text { Streich } \\
U\end{array}$ & $\begin{array}{c}\text { Ib } \\
E E G- \\
g e\end{array}$ & $\begin{array}{c}\text { IIa } \\
\text { Abschaffu } \\
\text { ste }\end{array}$ & \begin{tabular}{l}
\multicolumn{1}{c}{ IIb } \\
$g$ Energie- \\
uer
\end{tabular} \\
\hline & & $\begin{array}{c}\text { terneh- } \\
\text { men }\end{array}$ & 40 & 60 & 120 & $\begin{array}{c}60- \\
\text { EEG }\end{array}$ & $\begin{array}{l}120- \\
\text { EEG }\end{array}$ & $\begin{array}{c}120 \text { - } \\
\text { En.steuer }\end{array}$ & $\begin{array}{l}60 \text { - halbe } \\
\text { En.steuer }\end{array}$ \\
\hline Bäcker & alle & 53.1 & 84 & 126 & 251 & -188 & -62 & -45 & -23 \\
\hline & klein & 7.7 & 121 & 181 & 362 & -258 & -77 & 50 & 25 \\
\hline & groß & 93.4 & 81 & 122 & 243 & -183 & -61 & -52 & -26 \\
\hline Fleischer & alle & 18.1 & 199 & 299 & 597 & -642 & -343 & 73 & 36 \\
\hline & klein & 6.2 & 105 & 157 & 314 & -594 & -437 & -30 & -15 \\
\hline & groß & 34.6 & 222 & 333 & 666 & -653 & -320 & 98 & 49 \\
\hline Friseur & alle & 4.7 & 56 & 84 & 167 & -40 & 44 & 70 & 35 \\
\hline & klein & 3.1 & 72 & 107 & 215 & -34 & 73 & 98 & 49 \\
\hline & groß & 6.6 & 46 & 69 & 138 & -41 & 27 & 53 & 26 \\
\hline $\mathbf{K f z}$ & alle & 22.4 & 77 & 115 & 230 & -64 & 51 & 87 & 43 \\
\hline & klein & 10.4 & 133 & 199 & 398 & -10 & 189 & 194 & 97 \\
\hline & groß & 45.5 & 55 & 82 & 165 & -85 & -3 & 45 & 23 \\
\hline Metall & alle & 24.7 & 37 & 55 & 111 & -636 & -581 & -113 & -57 \\
\hline & klein & 12 & 44 & 65 & 131 & -481 & -416 & -67 & -34 \\
\hline & groß & 37.4 & 34 & 51 & 101 & -691 & -640 & -130 & -65 \\
\hline $\begin{array}{l}\text { Textilreini- } \\
\text { ger }\end{array}$ & alle & 7.5 & 526 & 789 & 1577 & 469 & 1257 & 834 & 417 \\
\hline & $\begin{array}{l}\text { klein } \\
\text { groß }\end{array}$ & & & & & & & & \\
\hline Tischler & alle & 12.6 & 19 & 29 & 58 & -270 & -242 & -44 & -22 \\
\hline & klein & 8.4 & 39 & 59 & 118 & -221 & -162 & 1 & 0 \\
\hline & groß & 28.4 & 7 & 11 & 21 & -360 & -349 & -88 & -44 \\
\hline
\end{tabular}

Anmerkungen:

*Aufgrund der geringen Anzahl von Unternehmen im Datensatz wurde darauf verzichtet, zwischen großen und kleinen Unternehmen zu unterscheiden.

Negative Werte in der Tabelle entsprechen einer Kostenreduzierung.

Szenario Ia „60 - EEG“: Der $\mathrm{CO}_{2}$-Preis beträgt 60 Euro pro Tonne und die EEG-Umlage muss nicht gezahlt werden

Szenario Ib „120 - EEG“: Der $\mathrm{CO}_{2}$-Preis beträgt 120 Euro pro Tonne und die EEG-Umlage muss nicht gezahlt werden

Szenario IIa „120 - En.steuer“: Der $\mathrm{CO}_{2}$-Preis beträgt 120 Euro pro Tonne und es fällt keine Energiesteuer an.

Szenario IIb „60 - halbe En.steuer“: Der $\mathrm{CO}_{2}$-Preis beträgt 60 Euro pro Tonne und die Energiesteuer wird um die Hälfte reduziert. 


\section{Unternehmerische Anpassungen an die erhöhten Kosten}

Wie dargelegt ergeben sich für die Unternehmen durch eine $\mathrm{CO}_{2}$-Bepreisung unterschiedlich starke Kostenbelastungen, woraus ein uneinheitliches Bild resultiert: In Abhängigkeit von der eingesetzten Primärenergie werden die Unternehmen innerhalb eines Gewerkes unterschiedlich stark belastet. $\mathrm{CO}_{2}$-neutral wirtschaftende Unternehmen profitieren. Bei $\mathrm{CO}_{2}$-intensiven Unternehmen kann ein Energieträgerwechsel, der Einsatz von erneuerbaren Energien und das Ausschöpfen von Energieeffizienzpotenzialen helfen, die zusätzlichen Kosten zu reduzieren. In diesem Abschnitt soll abgeschätzt werden, welche unternehmerischen Anpassungsmaßnahmen in der kurzen Frist (1 - 4 Jahre) zu erwarten sind. Es wird angenommen, dass keine Kompensation (durch Streichung der EEG-Umlage oder der Energiesteuer) erfolgt, denn, wie bereits gezeigt wurde, entstehen im Fall einer solchen Kompensation kaum Mehrkosten für Handwerksunternehmen (mit Ausnahme der Textilreiniger). Am Ende wird die Frage beantwortet, inwieweit die Mehrkosten, welche durch $\mathrm{CO}_{2}$-Bepreisung entstehen, durch Anpassungsmaßnahmen kompensiert werden können. Eine mittel- und langfristige Abschätzung wird dabei nicht vorgenommen, da neue Technologien und komplexe Interaktionen zu innovativen Anpassungen führen können, die nicht absehbar sind.

\subsection{Vorgehensweise}

Innerhalb jedes Handwerkszweiges wurden sogenannte Mittelwertunternehmen generiert, welche in allen Eigenschaften (Verbräuche, Anzahl der Mitarbeiter etc.) den durchschnittlichen Wert der im Datensatz befindlichen Unternehmen aufweisen. Tabelle 5 stellt die Energiekosten, die $\mathrm{CO}_{2}$-Emission und die strombedingten Emissionen für die sieben Mittelwertunternehmen dar. Der Anteil der strombedingten Emission ist mit Ausnahme von Textilreinigern groß und im Falle der Metall-Betriebe und Tischler sehr groß. Es wird hier davon ausgegangen, dass die strombedingten $\mathrm{CO}_{2}$-Emissionen bereits durch das ETS abgedeckt werden und keine Doppelbelastung erfolgt.

Tabelle 4 zeigt die sieben Handwerkszweige mit den Mittelwerten der Betriebsgrößen und die Mittelwerte der relevanten Energiequellen. Hinter den Verbrauchswerten stehen i.d.R. vielfältige Prozesse zum Beispiel zum (Auf-) Heizen, Reinigen, Verarbeiten oder Reparieren. In der Bäckerei verbrauchen die Backöfen mehr als die Hälfte der Energie, im Metallbereich gibt es Öfen und Galvanikbecken. In allen anderen hier untersuchten Gewerken gibt es keinen vergleichbaren gewerkespezifischen Groß-Verbraucher. 
Tabelle 5 stellt die Energiekosten, die $\mathrm{CO}_{2}$-Emission und die strombedingten Emissionen für die sieben Mittelwertunternehmen dar. Der Anteil der strombedingten Emission ist mit Ausnahme von Textilreinigern groß und im Falle der Metall-Betriebe und Tischler sehr groß. Es wird hier davon ausgegangen, dass die strombedingten $\mathrm{CO}_{2}$-Emissionen bereits durch das ETS abgedeckt werden und keine Doppelbelastung erfolgt.

Tabelle 4: $\quad$ Mittelwertbetriebe, Überblick Größe und Verbrauchswerte

\begin{tabular}{|c|c|c|c|c|c|c|}
\hline Gewerk & \begin{tabular}{|l}
\multicolumn{2}{|l|}{ Mitarbei- } \\
ter Voll- \\
zeit- \\
äquivalent
\end{tabular} & $\begin{array}{l}\text { Beheizte } \\
\text { Gebäu- } \\
\text { defläche } \\
{\left[\mathrm{m}^{2}\right]}\end{array}$ & $\begin{array}{l}\text { Strom- } \\
\text { ver- } \\
\text { brauch } \\
\text { [kWh/a] }\end{array}$ & $\begin{array}{l}\text { Gas- } \\
\text { verbrauch } \\
\text { [kWh/a] }\end{array}$ & $\begin{array}{l}\text { Öl- } \\
\text { verbrauch } \\
\text { [kWh/a] }\end{array}$ & $\begin{array}{l}\text { Fernwärme- } \\
\text { verbrauch } \\
\text { [kWh/a] }\end{array}$ \\
\hline Bäcker & 53,1 & 1330,6 & 213.263 & 138.171 & 88.094 & 155.949 \\
\hline Fleischer & 18,1 & 778,8 & 218.750 & 348.680 & 8.339 & 911 \\
\hline Friseure & 4,7 & 200,3 & 7.235 & 10.560 & 11.609 & 226 \\
\hline Kfz & 22,4 & 1337,8 & 51.594 & 42.995 & 95.847 & 7.868 \\
\hline Metall & 24,7 & 1478,2 & 218.431 & 37.367 & 7.869 & 0 \\
\hline $\begin{array}{l}\text { Textilreini- } \\
\text { ger }\end{array}$ & 7,6 & 168,0 & 23.901 & 228.258 & 104.377 & 0 \\
\hline Tischler & 12,6 & 1221,6 & 48.409 & 8.657 & 12.081 & 421 \\
\hline
\end{tabular}

Es soll nun abgeschätzt werden, wie viele $\mathrm{CO}_{2}$-Emissionen die Mittelwertunternehmen durch bestimmte Anpassungsmaßnahmen einsparen können. Zwei mögliche Anpassungsmechanismen wurden identifiziert:

Zunächst können allgemeine Energieeffizienzmaßnahmen dazu führen, dass Energie (und damit $\mathrm{CO}_{2}$-Emissionen) eingespart wird. Im Rahmen der MIE-Unternehmensberatungen wurden bereits verschiedene Einzelmaßnahmen im Bereich der Energieeffizienz identifiziert und deren Energieeinsparpotenziale abgeschätzt. Diese Energieeinsparungen können wiederum in $\mathrm{CO}_{2}$-Einsparungen umgerechnet werden.

Neben den Energieeffizienzmaßnahmen werden Anpassungen im Bereich der Wärmeerzeugung untersucht, welche die $\mathrm{CO}_{2}$-Emissionen ebenfalls reduzieren. Im einfachsten Fall wird angenommen, dass Öl durch Erdgas ersetzt wird. Nichtsdestoweniger werden viele Wärmesysteme über 15 Jahre hinweg genutzt, so dass in der kurzen Frist nur ein Teil der Unternehmen umrüsten wird. In den Bereichen Friseur, Kfz und Tischlerei wurde angenommen, dass der Wärmebedarf, welcher bisher aus Öl und Gas gespeist wird, zu 30 \%, $30 \%$ und 50 \% durch den Einbau von Wärmepumpen abgedeckt wird. 
Tabelle 5: $\quad$ Mittelwertbetriebe, Überblick Energiekosten und CO2-Emission

\begin{tabular}{|c|c|c|c|c|c|c|c|c|}
\hline Gewerk & $\begin{array}{l}\text { Energiekosten } \\
\text { Gesamt (netto) } \\
\text { [€/a] }\end{array}$ & $\begin{array}{l}\text { Energiekos- } \\
\text { ten Wärme } \\
\text { (netto) [€/a] }\end{array}$ & $\begin{array}{ll}\text { Anteil } & \text { Wärme } \\
\text { an } & \text { Gesamt } \\
{[\text { \%] }} & \end{array}$ & $\begin{array}{l}\text { Energiekos- } \\
\text { ten Strom } \\
\text { (netto) }[€ / a]\end{array}$ & \begin{tabular}{|l|} 
Anteil \\
Strom an \\
Gesamt \\
[ \%]
\end{tabular} & $\begin{array}{l}\mathrm{CO}_{2^{-}} \\
\text {Emission } \\
\text { nach BAFA- } \\
\text { Zahlen } \\
\text { [t/a] }\end{array}$ & $\begin{array}{l}\text { Davon strom- } \\
\text { bedingte } \mathrm{CO}_{2} \\
\text { Emissionen } \\
\text { (t/a) }\end{array}$ & $\begin{array}{l}\text { Anteil Strom an } \\
\mathrm{CO}_{2} \text { Emission }\end{array}$ \\
\hline Bäcker & $51.106 €$ & $17.604 €$ & $34 \%$ & $31.112 €$ & $61 \%$ & 237,7 & 126,5 & $53 \%$ \\
\hline Fleischer & $62.268 €$ & $17.441 €$ & $28 \%$ & $40.745 €$ & $65 \%$ & 220,1 & 129,7 & $59 \%$ \\
\hline Metall & $44.318 €$ & $6.430 €$ & $15 \%$ & $36.288 €$ & $82 \%$ & 151,9 & 129,5 & $85 \%$ \\
\hline Textilreiniger & $16.715 €$ & $10.789 €$ & $65 \%$ & $5.739 €$ & $34 \%$ & 103,3 & 14,2 & $14 \%$ \\
\hline Tischler & $12.496 €$ & $2.933 €$ & $23 \%$ & $9.659 €$ & $77 \%$ & $34,8^{*}$ & 28,7 & $83 \%$ \\
\hline
\end{tabular}

Anmerkung: *Die $\mathrm{CO}_{2}$-Emissionen sind relativ, wenn Holzreste aus nachhaltiger Forstwirtschaft verbrannt werden. 


\subsection{Energieeffizienz-Anpassungen nach Handwerkszweig}

Auf Basis der Einschätzung der Energieeffizienzexperten der $\mathrm{MIE}^{1}$ können bestimmte Energieeffizienzmaßnahmen zu Einsparungen der $\mathrm{CO}_{2}$-Emmissionen beitragen. Im Folgenden wird für jeden Handwerkszweig einzeln aufgeführt, welche Energie- und $\mathrm{CO}_{2}$ - Einsparungen sich aus den verschiedenen Effizienzmaßnahmen ergeben. Die Energieeinsparabschätzungen beruhen dabei auf den Einschätzungen der MIE-Experten, welche im Rahmen von Betriebsbegehungen vorgenommen wurden.

\subsubsection{Bäcker}

Ein Bäcker-Mittelwertbetrieb hat 4,9 Filialen mit insgesamt 53,1 Mitarbeitern. Er verarbeitet 291 t Mehl zu Lebensmitteln, wobei er 237,7 t CO 2 emittiert. Mit insgesamt 595 MWh bezieht der Bäcker die größte summierte Energiemenge aus Strom (213 MWh), Gas (138 MWh), Öl (88 MWh) und Fernwärme (156 MWh, siehe Tabelle 23). Mehr als die Hälfte des gesamten Energieeinsatzes entfällt auf Backöfen. Die Backöfen werden mit Strom, Gas oder Erdöl betrieben. Erdöl wäre durch - eine Steuerlösung unterstellt - eine $\mathrm{CO}_{2}$-Bepreisung am stärksten belastet, bei den betroffenen Unternehmen kann dementsprechend ein Energieträgerwechsel erwartet werden.

Neben dem Ofen gibt es noch elektrisch betriebene Kühlgeräte und die Beleuchtung als relevante durch Strom betriebene Geräte, aber auch elektrische Kleingeräte wie Kneter, Teigmixer, Brötchenpressen, Spülmaschinen etc., die zum Energieverbrauch beitragen und ggf. kleinteiliges Einsparpotenzial aufweisen. Da jedoch für diese Analyse angenommen wird, dass diese strombetriebenen Vorgänge keiner zusätzlichen $\mathrm{CO}_{2}$-Bepreisung unterliegen, spielen sie in der aktuellen Betrachtung keine Rolle. Das heißt: Obwohl strombedingte Energieeffizienzmaßnahmen $\mathrm{CO}_{2}$ einsparen und das Unternehmen entlasten, indem die Kosten und (ETS-)Abgaben sinken, kann das Unternehmen in diesem Bereich keine $\mathrm{CO}_{2}$-Kosten sparen, da der Strombereich nicht verteuert wird, sondern bereits dem ETS unterliegt.

Tabelle 6 zeigt das maßnahmenbezogene Einsparpotenzial, welches durch Effizienzsteigerung zu erreichen ist.

\footnotetext{
${ }^{1}$ Die Gewerksteckbriefe der MIE können auf www.energieeffizenz-handwerk.de eingesehen werden. - 120 -
} 
Tabelle 6: Kosten und maßnahmenbezogene Einsparpotenziale der Bäcker ${ }^{2}$

\begin{tabular}{|l|l|l|l|}
\hline Maßnahme & Kosten & Einsparpotenzial & Beschreibung anhand Bsp. \\
\hline Prozesswärme & Hoch & $3,54 \mathrm{t} \mathrm{CO}_{2} / \mathrm{a}$ & $\begin{array}{l}\text { Stufenbrenner Herdtürendäm- } \\
\text { mung } \\
\text { Herdgruppensteuerung } \\
\text { Wärmerückgewinnung } \\
\text { Abgasklappen im Kamin }\end{array}$ \\
\hline $\begin{array}{l}\text { Heiztechnik / Gebäude- } \\
\text { hülle }\end{array}$ & Hoch & $1,24 \mathrm{t} \mathrm{CO}_{2} / \mathrm{a}$ & $\begin{array}{l}\text { Einsatz erneuerbare Energien } \\
\text { Dämmen und Sanieren }\end{array}$ \\
\hline
\end{tabular}

Anmerkung: Die dargestellten $\mathrm{CO}_{2}$-Einsparungen basieren auf Schätzungen der Mittelstandsinitiative Energiewende und Klimaschutz (MIE).

Der Zentralverband des Deutschen Handwerk (ZDH) empfiehlt bei Neuanschaffung von Backöfen die „Ausrüstung mit Stufenbrenner, Herdtürendämmung und Herdgruppensteuerung“, den Einsatz von Wärmerückgewinnung aus Schwaden und Abgasen, sowie das Nachrüsten von Abgasklappen im Kamin. Die Wärmerückgewinnung kann durch die Rückführung der gereinigten Luft erfolgen. Neben Investitionen in technische Nachrüstung weist auch die Prozessoptimierung ein großes Potenzial auf. Beispielsweise kann die Backflächenausnutzung, Ofeneinschaltzeit und die Schwadenmenge optimiert werden. Falls noch nicht durchgeführt, empfiehlt sich eine professionelle Energieeffizienz-Analyse, ein Energie-ManagementSystem (EMAS/ISO 50001) und Energieverbrauchs-Monitoring, z.B. mittels des von der MIE entwickelten „Energiebuchs für Handwerksbetriebe“. Die Energieeffizienz-Analyse empfiehlt sich gewerkeübergreifend in allen Handwerksbereich, wird jedoch im Folgenden nicht mehrmals genannt.

\subsubsection{Fleischer}

Ein Fleischer-Mittelwertbetrieb hat 1,8 Filialen und beschäftigt 18,1 Mitarbeiter. Er verarbeitet 312 t Fleisch pro Jahr und emittiert dabei 220,1 t CO2. Mit 219 MWh Strom-, 349 MWh Gas- und 8 MWh Ölverbrauch im Jahr ist der Fleischer ebenfalls ein energieintensives Gewerk. Aufgrund der vielfältigen Verbraucher ist das Energiesparpotenzial kleinteilig und breit gefächert. Kochen, Garen und Backen sind die energieintensivsten Vorgänge. Kochkessel werden meist mit Erdgas oder Heizöl direktbefeuert. Dem Fleischer mit ölbefeuertem Kochkessel würde durch die $\mathrm{CO}_{2}$-Bepreisung ein finanzieller Nachteil gegenüber dem Fleischer mit gasbefeuertem Kochkessel entstehen. Ein Energieträgerwechsel, vor allem bei Neuanschaffung, ist daher sinnvoll.

\footnotetext{
2 (ZDH, Die energieeffiziente Bäckerei, 2017 http://www.energieeffizienz-handwerk.de/files/824/928336.pdf)
} 
Die Kälteversorgung dagegen wird mit strombetriebenen Kompressionskältemaschinen oder Sorptionskältemaschinen gewährleistet, und die Hälfte des Stromverbrauchs beim Fleischer ist der Kälteerzeugung zuzuordnen. Das Potenzial der netzdienlichen Flexibilität durch erzeugungsgeführten Betrieb der Kältemaschinen ist somit in diesem Gewerk am größten. Indem die zulässigen Temperaturbänder ausgenutzt werden, kann der Stromverbrauch auf Zeiten mit hohem Angebot an erneuerbarer Energie gelegt werden. Ein finanzieller Anreiz ergibt sich dank Energieversorgern mit variablen Stromtarifen für Industrie und Gewerbe. Dank der thermischen Eigenschaften (Trägheit) ist ein Kühlhaus ein sehr guter Speicher, um überschüssigen Strom zu verbrauchen und den Strombedarf in Zeiten von Strommangel zu reduzieren. Tabelle 7 zeigt das maßnahmenbezogene Einsparpotenzial, welches durch Effizienzsteigerung zu erreichen ist. Wie in den anderen Fallbeispielen empfiehlt es sich auch hier, eine professionelle Energieeffizienz Analyse, ein Energie Management System (ISO 50001) und Energieverbrauchs-Monitoring durchzuführen.

Tabelle 7: $\quad$ Kosten und maßnahmenbezogene Einsparpotenziale der Fleischer ${ }^{3}$

\begin{tabular}{|l|l|l|l|}
\hline Maßnahme & Kosten & Einsparpotenzial & Beschreibung \\
\hline $\begin{array}{l}\text { Heiztechnik / Gebäude- } \\
\text { hülle }\end{array}$ & Hoch & $7,95 \mathrm{t} \mathrm{CO}_{2} / \mathrm{a}$ & $\begin{array}{l}\text { Einsatz erneuerbare Energien } \\
\text { Dämmen und Sanieren } \\
\text { Hydraulischer Abgleich }\end{array}$ \\
\hline Prozesswärme & Mittel & $12,2 \mathrm{t} \mathrm{CO}_{2} / \mathrm{a}$ & $\begin{array}{l}\text { Wasserinhalt reduzieren } \\
\text { Deckel/Türen geschlossen } \\
\text { Anlagenauslastung erhöhen } \\
\text { Kochtemperaturmanagement }\end{array}$ \\
& & & \\
\hline
\end{tabular}

\subsubsection{Friseure}

Ein Friseur-Mittelwertbetrieb beschäftigt 4,7 Mitarbeiter und emittiert 10,6 t CO 2 im Jahr. Mit 7 MWh Strom-, 10 MWh Gas- und 12 MWh Ölverbrauch im Jahr ist der Friseur ein verhältnismäßig energiesparsames Gewerk. Die Energiekosten betragen aber knapp $3.000 €$ im Jahr und sind ein relevanter Faktor für den Betrieb. Die Hälfte des Energieverbrauchs kann dabei der Beheizung des Salons zugerechnet werden, welche, wie oben erläutert, ein hohes Einsparpotenzial aufweist. Die verbleibende Energie wird unter anderem für Beleuchtung, Fön, Trockenhaube, Waschmaschinen, Trockner, Warmwassererzeugung und Klimatisierung eingesetzt. Hier sind ggf. kleinteilige Einsparpotenziale, vor allem bei ohnehin anstehenden Neuanschaffungen, realisierbar.

\footnotetext{
${ }^{3}$ ZDH, Die energieeffiziente Fleischerei, 2017
} 
Tabelle 8: $\quad$ Kosten und maßnahmenbezogene Einsparpotenziale beim Friseur ${ }^{4}$

\begin{tabular}{|l|l|l|l|}
\hline Maßnahme & Kosten & Einsparpotenzial & Beschreibung \\
\hline $\begin{array}{l}\text { Heiztechnik / Gebäude- } \\
\text { hülle }\end{array}$ & Hoch & $0,96 \mathrm{t} \mathrm{CO}_{2} / \mathrm{a}$ & $\begin{array}{l}\text { Einsatz erneuerbare Energien } \\
\text { Dämmen und Sanieren } \\
\text { Hydraulischer Abgleich }\end{array}$ \\
\hline Prozesswärme & Mittel & $0,67 \mathrm{t} \mathrm{CO}_{2} / \mathrm{a}$ & Warmwasseroptimierung \\
\hline
\end{tabular}

\subsubsection{Kfz-Handwerk}

Ein Kfz-Mittelwertbetrieb beschäftigt 22,4 Mitarbeiter und emittiert 73,7 t $\mathrm{CO}_{2}$ im Jahr. Mit 52 MWh Strom-, 43 MWh Gas-, 10 MWh Ölverbrauch und 8 MWh Fernwärmebezug im Jahr haben Kfz-Reparaturbetriebe einen mittelgroßen Energiebedarf.

Das größte Einsparpotenzial weisen auch im Kfz-Betrieb die Heiztechnik und Gebäudehülle auf, da sehr viel Energie durch Außenbauteile (ungedämmte Wand, ungedämmtes Dach, alte Fenster/Verglasung) und offene oder langsam schließende Tore und Türen verloren geht. Nachdem die Wärmeverluste minimiert sind, sollte die bestehende Heizung geprüft und bei einer Neuanschaffung der Einsatz von erneuerbarer Energie und der reduzierte Heizbedarf bei der Dimensionierung berücksichtigt werden, um Kosten zu sparen. Auf die Beleuchtung entfallen ca. $25 \%$ des Stromverbrauchs. Durch das Umrüsten der Beleuchtungssysteme auf LED-Leuchtmittel und einer bedarfsgerechten und helligkeitsabhängigen Schaltung lassen sich oft mehr als $20 \%$ dieses Energieverbrauchs vermeiden.

Druckluft wird für Werkzeug (Schlagschrauber, Reifenfüllgeräte, Hebebühnen etc.) genutzt und weist ein Einsparpotenzial von bis zu 20 \% auf. Der Kompressor sollte außerhalb der Betriebszeiten ausgeschaltet sein und das Druckniveau auf den Bedarf optimiert werden. Eine regelmäßige Prüfung von Kompressor und Leitungsnetz zur frühzeitigen Identifikation von Leckagen ist empfehlenswert. Die Abwärme kann genutzt werden. Wo möglich, kann der Umstieg zu effizienten und elektrischen Geräten vorteilhaft sein. Tabelle 9 zeigt das maßnahmenbezogene Einsparpotenzial, welches durch Effizienzsteigerung zu erreichen ist.

\footnotetext{
${ }^{4}$ ZDH, Der energieeffiziente Friseursalon, 2017, www.energieeffizienz-handwerk.de/files/830/628783.pdf - 123 -
} 
Tabelle 9: Kosten und maßnahmenbezogene Einsparpotenziale beim Kfz-Betrieb ${ }^{5}$

\begin{tabular}{|l|l|l|l|}
\hline Maßnahme & Kosten & Einsparpotenzial & Beschreibung \\
\hline Heiztechnik / Gebäude- & Hoch & $8,85 \mathrm{t} \mathrm{CO}_{2} / \mathrm{a}$ & Einsatz erneuerbare Energien \\
& & & Dämmen und Sanieren \\
& & & $\begin{array}{l}\text { Hydraulischer Abgleich } \\
\text { Schnell schließende Tore }\end{array}$ \\
\hline
\end{tabular}

\subsubsection{Metallverarbeitende Betriebe}

Ein durchschnittlicher metallverarbeitender Betrieb beschäftigt 24,7 Mitarbeiter und emittiert 151,9 t CO 2 im Jahr. Mit 218 MWh Strom-, 37 MWh Gas- und 8 MWh Ölverbrauch im Jahr ist der Metall-Betrieb ein Gewerk mit mittelgroßem Energiebedarf.

Allgemeingültige Aussagen über die Einsparpotenziale sind für den Metall-Betrieb schwieriger zu treffen, da das Leistungsspektrum des Gewerkes sehr breit gefächert ist. Die Maschinen und Anlagen sowie den Fertigungsprozess gilt es im Einzelnen auf Einsparpotenziale hin zu überprüfen. Regelmäßige Wartung, bedarfsgerechter Betrieb, optimale Dimensionierung und die Nutzung der prozessbedingten Verlustenergie bergen oft Einsparpotenziale. Die Auswahl eines Energieverantwortlichen und die Schulung der Belegschaft zum sparsamen Umgang mit Energie sind organisatorische Maßnahmen zur Reduktion von Energieverbräuchen.

Ein sehr großes Einsparpotenzial weisen im Metall-Betrieb die Heiztechnik und Gebäudehülle auf, da sehr viel Energie durch Außenbauteile (ungedämmte Wand, ungedämmtes Dach, alte Fenster/Verglasung) und offene oder langsam schließende Tore und Türen verloren geht. Tabelle 10 zeigt das maßnahmenbezogene Einsparpotenzial, welches durch Effizienzsteigerung zu erreichen ist.

Tabelle 10: Kosten und maßnahmenbezogene Einsparpotenziale beim Metall-Betrieb ${ }^{6}$

\begin{tabular}{|l|l|l|l|}
\hline Maßnahme & Kosten & Einsparpotenzial & Beschreibung \\
\hline $\begin{array}{l}\text { Heiztechnik / Gebäude- } \\
\text { hülle }\end{array}$ & Hoch & $62,00 \mathrm{t} \mathrm{CO}_{2} / \mathrm{a}$ & Einsatz erneuerbare Energien \\
& & & $\begin{array}{l}\text { Dämmen und Sanieren } \\
\text { Hydraulischer Abgleich } \\
\text { Schnell schließende Tore }\end{array}$ \\
\hline
\end{tabular}

\footnotetext{
5 ZDH, Der energieeffiziente Kfz-Betrieb, 2017, www.energieeffizienz-handwerk.de/files/820/862440.pdf

${ }^{6} \mathrm{ZDH}$, Der energieeffiziente metallverarbeitende Betrieb, 2017, www.energieeffizienzhandwerk.de/files/822/795467.pdf)
} 


\subsubsection{Textilreiniger}

Ein Textilreiniger-Mittelwertbetrieb beschäftigt 7,6 Mitarbeiter und emittiert 103,3 t CO im Jahr. Mit 24 MWh Strom-, 228 MWh Gas- und 104 MWh Ölverbrauch im Jahr ist der Textilreiniger ein Gewerk mit mittelgroßem bis großem Energiebedarf. In Textilreinigungen und Wäschereien sind die Energieverbraucher kleinteilig. Energie wird z.B. für Dampferzeugung, Reinigung, Trocknen, Finishen, Bügeln und Druckluft benötigt. Bei Neuanschaffung sollte auf eine hohe Effizienzklasse geachtet werden.

Betriebe mit hohem Ölverbrauch werden durch die $\mathrm{CO}_{2}$-Bepreisung einer erhöhten Belastung ausgesetzt sein, sodass sich ein Brennstoffwechsel anbietet.

Ein Großteil des Energiebedarfs wird für die Erzeugung von Dampf benötigt. Der Einsatz von erneuerbarer Energie (z.B. Photovoltaik oder Solarthermie) kann Kosten und Emissionen reduzieren. Die Heizungs- und Dampfleitungen, der Dampfkessel und der Warmwasserspeicher sollten gut isoliert sein, und die Abwärme kann zur Heizungsunterstützung oder Warmwasserbereitung genutzt werden. Der Energieanteil der Beleuchtung ist neben den energieintensiven Maschinen vergleichsweise gering. Aufgrund langer Nutzungszeiten besteht aber trotzdem ein großes Potenzial, die Energiekosten zu senken. Tabelle 12 zeigt das maßnahmenbezogene Einsparpotenzial, welches durch Effizienzsteigerung zu erreichen ist.

Tabelle 12: $\quad$ Kosten und maßnahmenbezogene Einsparpotenziale beim Textilreiniger ${ }^{7}$

\begin{tabular}{|l|l|l|l|}
\hline Maßnahme & Kosten & Einsparpotenzial & Beschreibung \\
\hline $\begin{array}{l}\text { Druckluft / Dampfer- } \\
\text { zeugung }\end{array}$ & Niedrig & $2,37 \mathrm{t} \mathrm{CO}_{2} / \mathrm{a}$ & $\begin{array}{l}\text { Bedarfsgerechte Nutzung } \\
\text { (Betriebszeit + Druckniveau) } \\
\text { Isolieren } \\
\text { Abwärme nutzen }\end{array}$ \\
\hline Prozesswärme & Mittel & 14,73 & $\begin{array}{l}\text { Verschiedene Einzelmaßnah- } \\
\text { men }\end{array}$ \\
\hline
\end{tabular}

\subsubsection{Tischler}

Ein Tischler-Mittelwertbetrieb beschäftigt 12,6 Mitarbeiter und emittiert 34,8 t $\mathrm{CO}_{2}$ im Jahr. Mit 48 MWh Strom-, 9 MWh Gas- und 12 MWh Ölverbrauch im Jahr ist der Tischler ein Gewerk mit verhältnismäßig geringem Energiebedarf. Beim Tischler sind die Energieverbraucher kleinteilig. Energie wird benötigt z.B. für Späneabsaugung, Lackierung, Druckluft-

\footnotetext{
${ }^{7}$ ZDH, Die energieeffiziente Textilreinigung/ Wäscherei, 2017, www.energieeffizienzhandwerk.de/files/821/269414.pdf
} 
bereitstellung, Beleuchtung und verschiedene Holzbearbeitungsmaschinen. Bei Neuanschaffungen sollte auf eine hohe Energieeffizienzklasse geachtet werden.

Betriebe mit hohem Ölverbrauch werden durch die $\mathrm{CO}_{2}$-Bepreisung einer erhöhten Belastung ausgesetzt sein, und ein Brennstoffwechsel bietet sich an.

Die Späneabsaugung ist für 38 \% des Strom- und 21 \% des Wärmeverbrauches verantwortlich. Die Wärmerückgewinnung kann durch die Rückführung der gereinigten Luft erfolgen. Der Einbau eines Frequenzumrichters zur bedarfsgerechten Anpassung der Luftmenge, der Austausch von Handschiebern durch elektrisch gesteuerte Schieber und die regelmäßige Wartung bergen weiteres Einsparpotenzial.

Die Gebäudehülle ist für 71 \% des Wärmeverbrauchs verantwortlich, die Dämmung der Gebäudehülle (Wand, Dach, Kellerdecke) und Erneuerung der Fenster, sowie Tore (schnell schließend) und Türen birgt auch beim Tischler-Betrieb ein großes Einsparpotenzial.

Tabelle 13: Kosten und maßnahmenbezogene Einsparpotenziale beim Tischler ${ }^{8}$

\begin{tabular}{|l|l|l|l|}
\hline Maßnahme & Kosten & Einsparpotenzial & Beschreibung \\
\hline Gebäudehülle & Hoch & $2,62 \mathrm{t} \mathrm{CO}_{2} / \mathrm{a}$ & Einsatz erneuerbare Energien \\
& & $\begin{array}{l}\text { Dämmen und Sanieren } \\
\text { Hydraulischer Abgleich } \\
\text { Schnell schließende Tore }\end{array}$ \\
\hline
\end{tabular}

\subsection{Anpassungsmaßnahmen der Wärmeerzeugung}

Neben den Anpassungen durch Energieeffizienzmaßnahmen kann das Unternehmen versuchen, durch Anpassungen im Bereich der Wärmeerzeugung $\mathrm{CO}_{2}$-Kosten einzusparen. Grundsätzlich gilt, dass gasbetriebene Heizanlagen weniger $\mathrm{CO}_{2}$ emittieren als ölbetriebene Anlagen. Obwohl die Umstellung auf alternative Heizsysteme in der Regel nur dann betriebswirtschaftlich sinnvoll ist, wenn die alte Heizanlage abgeschrieben ist, wird der Einfachheit wegen angenommen, dass die Maßnahme direkt vollzogen wird. Im Übrigen gehen wir davon aus, dass die Friseure, Kfz-Unternehmen und Tischler einen Teil (30 \%, 30 \% und 50 \%) ihrer bisherigen öl-basierten $\mathrm{CO}_{2}$-Emissionen reduzieren werden. Wir gehen davon aus, dass $\mathrm{CO}_{2}$ neutrale Systeme, wie Wärmepumpen, eingesetzt werden können. Dies ist allerdings nur dann rentabel, wenn das Gebäude gut saniert ist, damit keine zu hohen Stromkosten entstehen.

\footnotetext{
${ }^{8}$ ZDH, Die energieeffiziente Tischlerwerkstatt, 2017, www.energieeffizienz-handwerk.de/files/940/609632.pdf - 126 -
} 


\subsection{Neuberechnung der Kostenbelastung}

Insgesamt ergibt sich bei einer angenommenen $\mathrm{CO}_{2}$-Bepreisung von $120 €$ / t und ohne entsprechende Kompensation (durch Streichung der EEG-Umlage oder der Energiesteuer) eine Erhöhung der Energiekosten des Mittelwertunternehmens, welche unter den Handwerkszweigen zwischen 58 Euro (bei den Tischlern) und 1.577 Euro (bei den Textilreinigern) pro Mitarbeiter und Jahr verursacht. Wie oben beschrieben, können die Unternehmen Anpassungsmaßnahmen durchführen, welche die $\mathrm{CO}_{2}$ Emissionen und somit auch die Mehrkosten durch die $\mathrm{CO}_{2}$-Abgabe reduzieren. Bei den Friseuren und Tischlern sowie Kfz- und Metallunternehmen, welche nur eine geringe Mehrkostenbelastung aufweisen, können so die Mehrkosten komplett vermieden werden. Die Fleischer können durch die Maßnahmen etwa zwei Drittel ihrer Mehrkosten vermeiden. Bemerkenswert sind jedoch die Textilreiniger, bei denen die Anpassungsmaßnahmen nur zu einer 50 prozentigen Reduktion der Mehrkosten führen. Die Bäcker können ihre (geringen) Mehrkosten auch kaum vermeiden.

Abbildung 1: Mehrkostenbelastung pro Mitarbeiter und Jahr (in €, mit $\mathrm{CO}_{2}$-Bepreisung und Anpassungsmaßnahmen)

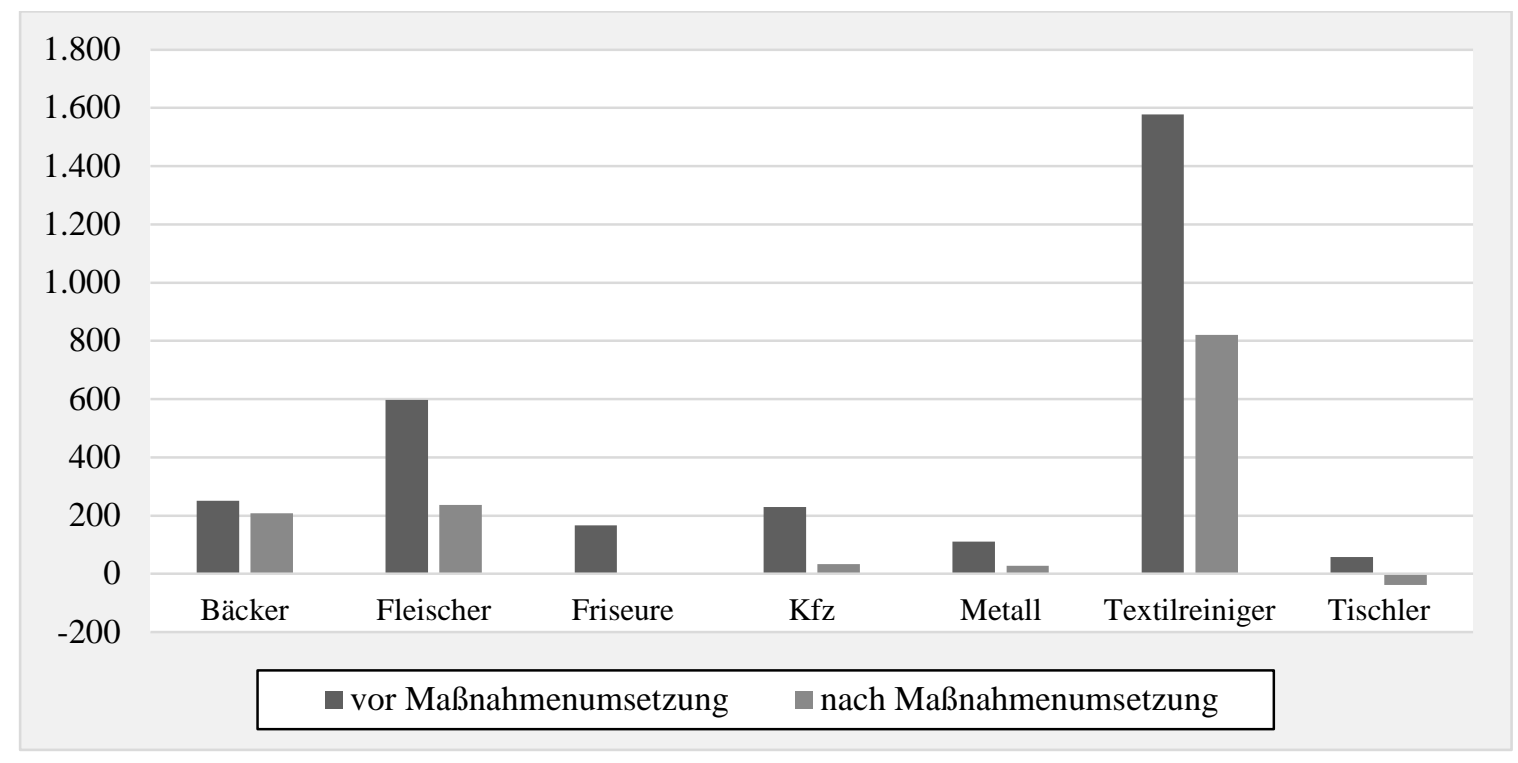

Anmerkung: Es wird angenommen, dass ein $\mathrm{CO}_{2}$-Preis von $120 € / t$ Anwendung findet und dass keine kompensatorischen politischen Maßnahmen (Bsp. die Streichung der EEG-Umlage) durchgeführt werden.

Bei diesen Zahlen ist jedoch zu beachten, dass nur Maßnahmen betrachtet wurden, die $\mathrm{CO}_{2}$ Emissionen aus dem Nicht-Strom-Bereich reduzieren. Diese Maßnahmen sind meist mit hohen Kosten verbunden. Auf der anderen Seite könnten weitaus günstigere Maßnahmen durchgeführt werden (wie bspw. die Umstellung der Beleuchtung auf LEDs), welche schneller und 
günstiger zu einem geringeren Energieverbrauch im Strombereich führen würden, jedoch keinen direkten Effekt auf eine Reduktion der durch $\mathrm{CO}_{2}$-Emissionen verursachten Mehrkosten haben, weil der Strom nicht besteuert wird. Es ist also insgesamt, davon auszugehen, dass obwohl die Unternehmen einen Großteil ihrer (geringen) Mehrkosten einsparen könnten, diese Maßnahmen teuer sind und kurzfristig nicht umgesetzt werden.

Abbildung 5 stellt die Gesamtkostenentwicklung (Gesamt-Energiekosten pro Mitarbeiter und Jahr) für die Mittelwertunternehmen in den sieben Handwerksunternehmen dar. Insgesamt lässt sich feststellen, dass ein Teil der zusätzlichen Kostenbelastung durch die relativ kostenintensiven Anpassungsmaßnahmen kompensiert werden kann. Vor diesem Hintergrund und vor dem Hintergrund der hohen Investitionskosten ergibt sich für die Mehrheit der Handwerksunternehmen die Vermutung, dass kurzfristig nur wenige Anpassungsmaßnahmen zu erwarten sind. Von den Textilreinigern abgesehen ergibt sich aber insgesamt auch nur eine geringe Mehrkostenbelastung durch die $\mathrm{CO}_{2}$-Bepreisung, selbst wenn keine Kompensation über die Streichung anderer Abgaben (wie beispielsweise der EEG-Umlage) erfolgt.

Abbildung 2: Energiekosten pro Mitarbeiter und Jahr (in €, vor und nach Einführung der $\mathrm{CO}_{2}$-Bepreisung)

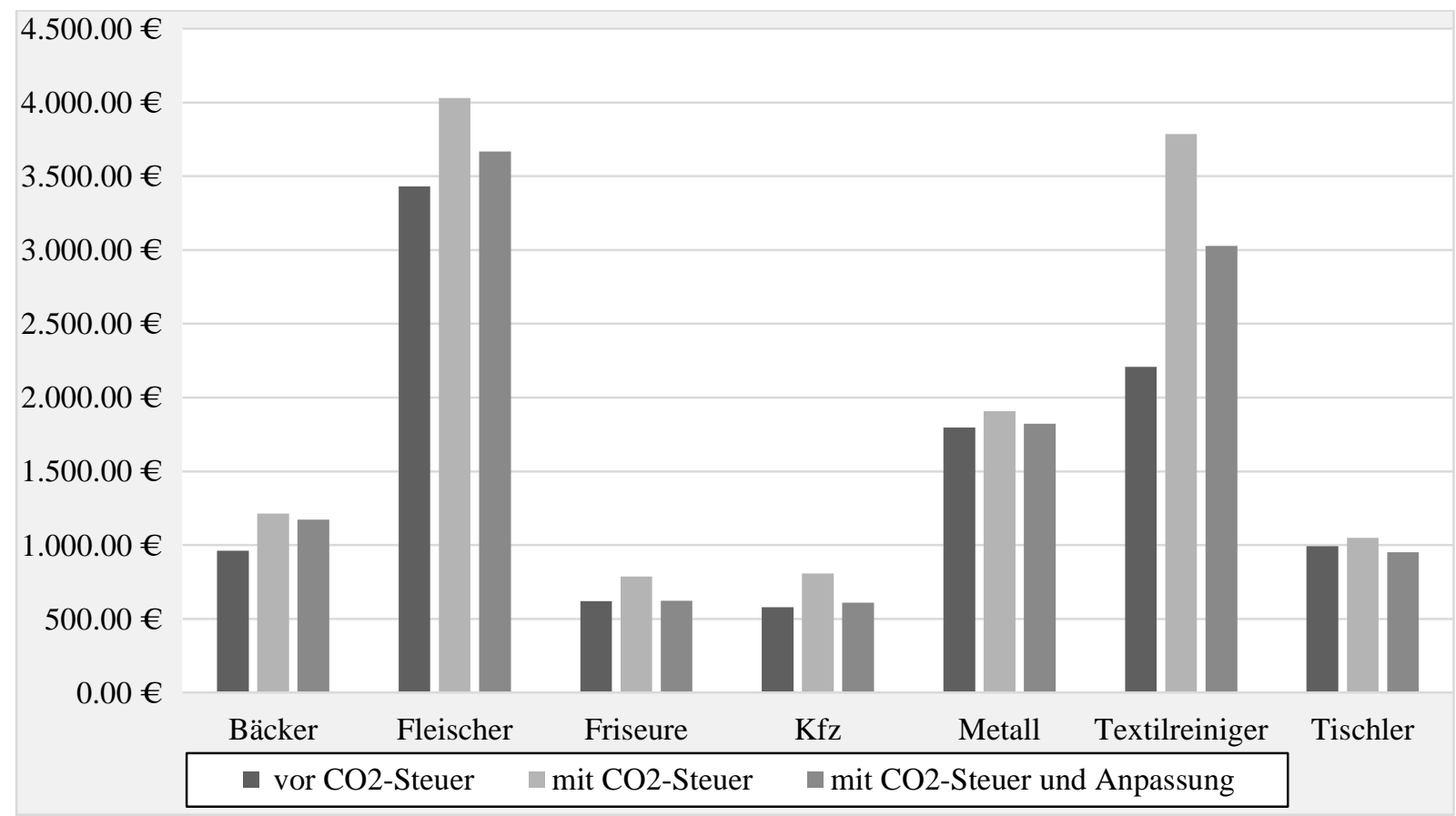

Anmerkung: Es wird angenommen, dass eine $\mathrm{CO}_{2}$-Abgabe von $120 € /$ t Anwendung findet und dass keine kompensatorischen politischen Maßnahmen (Bsp. die Streichung der EEG-Umlage) durchgeführt werden. 


\section{Fazit}

Die vorliegende Untersuchung leistet einen Beitrag zur aktuellen politischen Diskussion zur Einführung eines zusätzlichen $\mathrm{CO}_{2}$-Preises, welcher parallel zum bestehenden Zertifikatehandelssystem (ETS) bestehen könnte und die Energieverbrauchssektoren erfassen soll, welche aktuell nicht vom ETS abgedeckt werden. Andere europäische Länder wie Schweden, Norwegen oder die Schweiz haben diese Regulierungsoption - bei jeweils unterschiedlicher Ausgestaltung - umgesetzt. Im Speziellen wurde abgeschätzt, welche Kostenbelastung die Einführung einer solchen Bepreisung für Handwerksunternehmen mit sich bringen würde. Auf Basis von detaillierten Energieverbrauchsdaten von Handwerksunternehmen in sieben energieintensiven Handwerkszweigen konnten die $\mathrm{CO}_{2}$-Emissionen abgeschätzt werden, aus denen sich in den drei zugrunde gelegten Bepreisungsszenarien unterschiedliche Mehrkosten ergeben.

Bei einem $\mathrm{CO}_{2}$-Preis von $120 €$ / t liegt die durchschnittliche Mehrbelastung bei 300 Euro pro Mitarbeiter und Jahr. Dabei zeigte sich allerdings, dass die Mehrkosten, je nach Gewerk, sehr unterschiedlich ausfallen und zwischen 58 und mehr als 1500 Euro pro Mitarbeiter und Jahr liegen (siehe Tabelle 3). Des Weiteren wurden zwei Szenarien untersucht, in denen die zusätzliche Kostenbelastung durch die Streichung der EEG-Umlage bzw. der bisherigen Energiebesteuerung kompensiert wird. Die Einbeziehung kompensatorischer Maßnahmen ergibt sich aus der Tatsache, dass die $\mathrm{CO}_{2}$-Bepreisung nicht als Instrument zur Erzielung von Staatseinnahmen dient, sondern primär eine klimapolitische Lenkungswirkung ausüben soll und sich hieraus das Gebot der fiskalischen Neutralität ergibt. Es zeigt sich, dass die Abschaffung der EEG-Umlage die Einführung eines $\mathrm{CO}_{2}$-Preises von $120 €$ / t für alle Handwerkszweige (außer den Textilreinigern) kompensiert, sich also - zumindest für die Gruppe der untersuchten Gewerke/Unternehmen - keine zusätzlichen Kosten für Handwerksunternehmen ergäben. Im Falle der Kompensation durch die Abschaffung der Energiebesteuerung wären hingegen Mehrkosten die Folge, die jedoch deutlich unter dem Basisszenario (ohne Kompensation) lägen.

Schließlich wurde untersucht, auf welche Weise sich Handwerksunternehmen kurzfristig (ca. 1-4 Jahre) anpassen könnten. Zwei wesentliche Kanäle wurden in diesem Zusammenhang untersucht - die Durchführung von Energieeffizienzmaßnahmen und die Veränderung der betrieblichen Energie- insbesondere Wärmeerzeugung. Hieraus ergeben sich unterschiedliche Verminderungen der $\mathrm{CO}_{2}$-Preis bedingten Mehrkosten. Aufgrund der hohen Kosten der be- 
trachteten Maßnahmen kann davon ausgegangen werden, dass Unternehmen kurzfristig nur wenige Anpassungen vornehmen würden, weil sie primär wirtschaftlich agieren.

Als Fazit der Untersuchung kann festgehalten werden, dass die Einführung einer zusätzlichen $\mathrm{CO}_{2}$-Bepreisung im Falle der gleichzeitigen Einführung kompensatorischer Maßnahmen (wie die Abschaffung der EEG-Umlage) in der Mehrheit der Unternehmen keine kurzfristige (1-4 Jahre) Kostenmehrbelastung auslöst. Sofern keine kompensatorischen Maßnahmen ergriffen werden, steigen die Energiekosten der Unternehmen, wobei die betrachteten Gewerke unterschiedlich stark betroffen sind. Hierbei ist nicht davon auszugehen, dass diese Mehrkostenbelastung in der kurzen Frist durch Anpassungsmaßnahmen reduziert werden können.

Zwei Faktoren schränken die Aussagekraft der vorliegenden Studie ein. Zum einen wurde der Bereich Mobilität ausgeklammert, da hierfür keine verlässlichen Verbrauchsinformationen vorlagen. Zum anderen wurde untersucht, wie sich die Kostenbelastung der Unternehmen ändert, wenn $\mathrm{CO}_{2}$-Preise eingeführt/erhöht werden. Allerdings könnten sich als Folge einer solchen Politik und vor allem im Baubereich auch Umsatzpotenziale entfalten. Diese Umsatzsteigerungen durch Sanierungen, Neubauten etc. wurden in der vorliegenden Studie noch nicht berücksichtigt und stellen ein zukünftiges Untersuchungsfeld für die Gesamtabschätzung der Implikationen einer $\mathrm{CO}_{2}$-Bepreisung dar. 


\section{Literatur}

BAFA (2016) Energieberatungen im Mittelstand - Merkblatt für die Erstellung eines Beratungsberichts, 21.07.2016.

Feser, D., Proeger, T. \& Bizer, K. (2015). Die Energieberatung als der zentrale Akteur bei der energetischen Gebäudesanierung? Zeitschrift für Energiewirtschaft, 39 (2), 133-145.

Kremheller, A.; Schaefer, T. (2018). EEG: Eine neue Kostenabschätzung, IW-Policy Paper $15 / 18$.

Howard, P.; Sylan, D. (2015). Expert Consensus on the Economics of Climate Change. Institute of Policy Integrity, New York University.

Runst, P. (2016). Kurswechsel in der deutschen Klimapolitik am Beispiel der energetischen Gebäudesanierung, Wirtschaftsdienst - Zeitschrift für Wirtschaftspolitik, 96(5) : 340-43.

Runst, P.; Thonipara, A. (2019). Dosis Facit Effectum - Why The Scope of the Carbon Tax Matters. ifh working paper No. 19.

Thonipara, A.; Runst, P.; Ochsner, C.; Bizer, K. (2019). Energy Efficiency of Residential Buildings in the European Union, Energy Policy, 129:1156-1167. 


\section{Anhang}

Tabelle 11: Geschätzte jährliche Kostenbelastung der Unternehmen durch $\mathrm{CO}_{2}$-Bepreisung (pro Mitarbeiter, in €, schematische Darstellung)

\begin{tabular}{|c|c|c|c|c|c|c|c|c|}
\hline & & 40 & 60 & 120 & $\begin{array}{l}60- \\
\text { EEG }\end{array}$ & $\begin{array}{l}120- \\
\text { EEG }\end{array}$ & $\begin{array}{c}120 \text { - Esteu- } \\
\text { er }\end{array}$ & 60 -0.5 Esteuer \\
\hline \multirow[t]{3}{*}{ Bäcker } & alle & + & + & +++ & - & - & - & - \\
\hline & klein & + & + & +++ & - & - & + & + \\
\hline & groß & + & + & +++ & - & - & - & - \\
\hline \multirow[t]{3}{*}{ Fleischer } & alle & + & ++ & +++ & -- & -- & + & + \\
\hline & klein & + & + & ++ & -- & -- & - & - \\
\hline & groß & + & ++ & +++ & -- & -- & + & + \\
\hline \multirow{3}{*}{ Friseur } & alle & + & + & + & - & + & + & + \\
\hline & klein & + & + & + & - & + & + & + \\
\hline & groß & + & + & + & - & + & + & + \\
\hline \multirow[t]{3}{*}{$\mathbf{K f z}$} & alle & + & + & + & - & + & + & + \\
\hline & klein & + & + & ++ & - & + & + & + \\
\hline & groß & + & + & + & - & + & + & + \\
\hline \multirow[t]{3}{*}{ Metall } & alle & + & + & + & -- & + & + & + \\
\hline & klein & + & + & + & -- & + & + & + \\
\hline & groß & + & + & + & -- & + & + & + \\
\hline \multirow[t]{2}{*}{ Textilreiniger } & alle & ++ & +++ & +++ & ++ & +++ & +++ & ++ \\
\hline & $\begin{array}{l}\text { klein } \\
\text { groß }\end{array}$ & & & & & & & \\
\hline \multirow[t]{3}{*}{ Tischler } & alle & + & + & + & - & - & - & - \\
\hline & klein & + & + & + & - & - & & \\
\hline & groß & + & + & + & - & - & - & - \\
\hline
\end{tabular}

Anmerkung:

Die Zeichen +++/++/+ stehen für eine Mehrkostenbelastung von mehr als 500/ 300/ 0 Euro, während die Zeichen --/- für eine Minderbelastung von mehr als 300 /0 Euro stehen.

*Aufgrund der geringen Anzahl von Unternehmen im Datensatz wurde darauf verzichtet, zwischen großen und kleinen Unternehmen zu unterscheiden. 


\section{Chapter VI}

\section{Drivers of Energy Efficiency in Small Companies}

Submitted to:

Applied Energy, in January 2020 


\title{
Drivers of Energy Efficiency in Small Companies
}

\author{
Anita Thonipara*1 \\ Heinrich-Düker-Weg 6, 37073 Göttingen, Germany
}

\begin{abstract}
Despite the economic relevance of SMEs, which represent 99\% of all companies in the European Union, only few studies have investigated the drivers of energy efficiency among them. While the focus of former studies lays on larger industrial SMEs with high turnovers and a high level of automation, this study focuses on the drivers of energy efficiency measures in smaller, labor-intensive SMEs with comparatively low turnovers. Using in-depth interviews and a survey, I compare the importance of different drivers generally and to the results of former studies. The results suggest that management's environmental sensitivity is a key driver for energy efficiency measures in small companies with low turnovers which is mainly due to missing in-house capacities. These missing in-house capacities are also one of the reasons for the low importance of financial support programs. Instead, proactive and firm-specific consultations by external consultants are important drivers for smaller companies with low turnovers at certain points in time. Larger companies, on the other hand, prefer acquiring general information from outside in order to build up their in-house capacities. In these companies, financial support programs play a more important role in energy efficiency investments. Overall, the results suggest that in order to reach small companies, policymakers should focus on information campaigns to initiate management's own motivation. Furthermore, public financing programs should be customized according to the needs of these smaller companies by reducing the bureaucratic burden. In addition, offering firm-specific consultancy and close partnership should also be effective, whereas, for larger companies with high turnovers and high-cost investments, general information and support should be provided.
\end{abstract}

JEL: Q48, Q49, Q50

Keywords: energy efficiency, SMEs, drivers

\footnotetext{
* Corresponding author. Tel.: +49551 3917 4889. E-mail address: anita.thonipara@wiwi.uni-goettingen.de

I thank energy consultants of Chambers of Crafts and Trade for their comments and support in reaching SMEs. I particularly want to thank Anne Schütte from the Chamber of Crafts and Trade in Hildesheim for her patience and support.

This research is financially supported through a scholarship by the Volkswagen Stiftung (Volkswagen Foundation) as part of the "Practice Module to Connect Science and Practice” at the University of Göttingen as well as funding from the Institute for Small Business Economics at the University of Göttingen. 


\section{Introduction}

As a means of addressing climate change, the European Union set the goal to reduce energy consumption by 20\% by the year 2020 (Dukan 2019). According to recent analyses, this goal will not be reached. However, the goal to reduce energy consumption and hazardous greenhouse gas (GHG) emissions remains one of the most important challenges on the political agenda. The new President of the European Commission, Ursula von der Leyen, has therefore declared the reduction of hazardous greenhouse gas emissions as the highest political priority and called for Europe to follow the energy-efficiency-first principle (Council of the European Union 2019). As SMEs represent 99\% of all companies in the European Union (European Commission 2019), they need to be at the center of attention when discussing the promotion of energy efficiency measures as well as the reduction of carbon emissions in the private sector. However, SMEs often do not have the financial or temporal capacities to acquire the needed information to plan and finally implement energy efficiency measures in order to achieve major energy savings. In this context, it is of utmost importance to know how SMEs of different branches, sizes, scales of turnover and energy-intensity react and which factors are able to effectively drive energy efficiency measures.

So far, studies have focused almost exclusively on the barriers to energy efficiency in SMEs (Arens et al. 2017; Trianni and Cagno 2012; Sudhakara Reddy 2013; Hasanbeigi et al. 2009; Thollander and Ottoson 2008; de Groot et al. 2001; Önüt and Soner 2007) and found the lack of information and time as well as the costs or risks of production disruptions as the main barriers to energy efficiency investments.

While the barriers have already been widely analyzed, the drivers have so far been mostly neglected. Yet, in order to promote energy efficiency in SMEs, it could be more useful to know which factors foster energy efficiency in SMEs. There are only few studies which focus on certain drivers of energy efficiency in SMEs (Arens et al. 2017; Cagno and Trianni 2013; Tanaka 2011; Önüt and Soner 2007; Reddy and Assenza 2007). These studies considered mainly larger industrial companies with higher revenues which is probably due to the higher $\mathrm{CO}_{2}$ emissions expected from larger industrial SMEs. However, in order to achieve the ambitious goals for mitigating climate change, all SMEs, including small, very small companies as well as those with lower turnovers and revenues, have to reduce their greenhouse gas emissions. Thus, there is the need for research to address these companies, too. Another limitation in the studies already carried out is that they focused on specific drivers, instead of comparing the effectiveness of the different drivers with each other. 
Cagno and Trianni (2013) approached this by analyzing drivers of energy efficiency in 71 Italian manufacturing SMEs. After a comprehensive review of literature on drivers of energy efficiency in SMEs, they identified 14 drivers with allowances, public financing and external pressures being the major ones. Furthermore, the results suggested that there were differences in the drivers for energy efficiency depending on the size of the firms. However, the authors pointed out that the sample used was biased towards larger industrial SMEs with a high turnover.

Therefore, this study focuses on companies in segments of the SME sector which are often characterized by small companies with low turnovers. Understanding the needs of these companies and the drivers of energy efficiency within them is considered important for a holistic approach to promoting energy efficiency measures. Thus, the study analyzes the importance of the different drivers of energy efficiency measures in predominantly small companies.

For this purpose, qualitative methods are used consisting of in-depth expert interviews as well as a survey conducted in 80 companies which is extended by undertaking exploratory interviews in these same companies. The survey is based on that of Cagno and Trianni (2013) in order to make the results directly comparable to those for larger companies.

Due to the lack of theoretical groundwork and previous empirical studies, I choose an exploratory qualitative research method. This approach, while not leading to representative results in a statistical sense, provides some initial evidence for a specific and highly relevant sector and its SMEs. This evidence is used to generate hypotheses which can and should be tested by future quantitative studies to substantiate the drivers of energy efficient measures in SMEs identified in this study.

The remainder of this paper is structured as follows: Chapter 2 gives an overview of the methods, the sample specifics and description of the drivers used. The results are presented and discussed in Chapter 3 before the conclusions are drawn in Chapter 4. Tables of the results can be found in the appendix.

\section{Method}

\subsection{Method}

This study uses qualitative methods extended by a survey. In the first stage, in-depth expert interviews with energy efficiency consultants are conducted in order to obtain information on the relevant factors driving energy efficiency in small companies. In the second stage, a sur- 
vey based on the framework introduced by Cagno and Trianni (2013) is conducted and extended by exploratory interviews with the companies.

I consider 80 SMEs of different branches which are typically dominated by very small companies as well as those with low turnover and, thus, comparatively lower levels of profitability. Fifty-five of the companies were chosen randomly on the 2019 International Fair of Crafts and Trade in Munich. The other 25 companies were contacted by energy efficiency experts from the chambers of crafts and trade in order to reach companies from different branches. Only companies which implemented an energy efficiency measure within the past five years or had one planned for the upcoming one are considered for the survey. The interviews were conducted by myself and a trained student assistant so I was able to guarantee the correct classification of the answers given by the companies. Additionally, due to the open and exploratory nature of the interviews, I was able to receive more information on other factors which had not been considered in the survey.

First, the companies were asked to define which energy efficiency measures they had undertaken in the past five years, while the second question asked for the overall costs of those investments. After these two entry questions, the importance of the different drivers were queried which will be presented in Chapter 2, Section 3. In order to make the results comparable to those of Cagno and Trianni (2013), I use the same drivers plus others as well as a four point Likert Scale with 1= not important, 2 = less important, 3 = somewhat important, and 4 = very important. $^{2}$

The last part of the survey aimed at collecting company data to allow a statistical analysis. Questions were asked about the number of employees, turnover, the branch as well as the costs for last year's energy consumption. This way, the companies are assigned to different categories. Hence, I am able to present not only the general results, but also those related to firm size, turnover, energy-intensity and investment costs.

While Cagno and Trianni (2013) divided their sample into SEs (small enterprises) and MEs (medium -sized enterprises), my sample allow for a more detailed approach using six categories of company sizes. ${ }^{3}$ Furthermore, I analyze the answers according to turnover, energyintensity as well as the investment costs. Figure 1 displays the different categories defined for the analysis by firm size, turnover and investment costs.

\footnotetext{
${ }^{2}$ The four point Likert Scale using 1= not important, 2 = less important, 3 = somewhat important, and $4=$ very important also represent the answer options.

${ }^{3}$ These classes are defined according to the definition of firm size classes by the Federal Statistical Office and the Crafts Census.
} 


\section{Figure 1}

Definition of firm size, turnover and investment cost classes
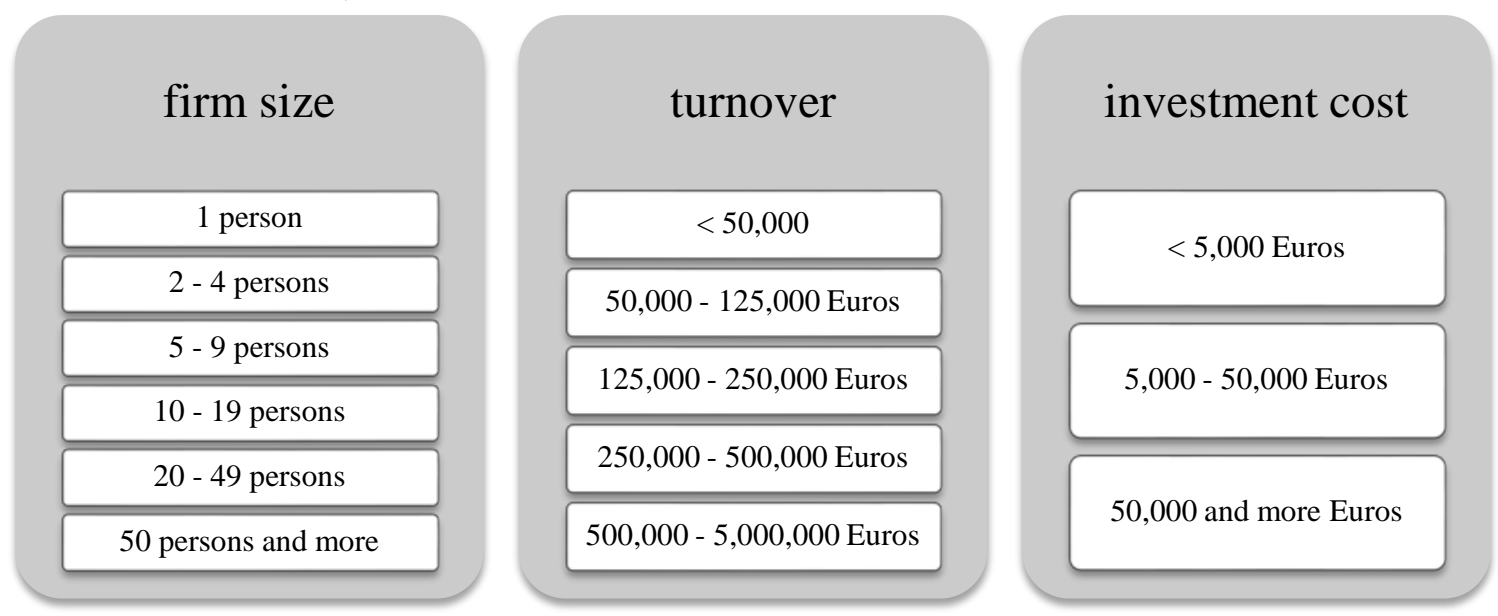

\subsection{Sample Specifics}

The sample's particularity is that it consists of small companies with low turnovers. The majority of them are small companies with 1 to 19 employees. Only 10 companies had 50 or more employees. The average turnover per employee in these professions is around 110,000 Euros, while the average turnover per enterprise is approximately 1,000,000 Euros (Federal and State Statistical Offices 2019). Considering that in larger industrial companies turnover per employee is on average around 290,000 Euros and 39,000,000 per enterprise, the companies in this sample have to be considered as low turnover ones (Federal and State Statistical Offices 2019). Hence, the companies considered are those for which energy efficiency investments pose a larger financial burden.

Table 1 presents the different professions represented in the sample and the superordinate branches with the number of observations in the sample.

Table 1

Sample Structure

\begin{tabular}{|c|c|c|c|}
\hline No & Branch & Examples of professions & $\begin{array}{c}\text { Number of } \\
\text { observations } \\
\text { in the sample }\end{array}$ \\
\hline $\mathrm{I}$ & Construction & Bricklayer and Concreter, Stonemason, Construction, Roofer & 8 \\
\hline II & Finishing craft & $\begin{array}{l}\text { Painter, Lacquerer, Installer and Heating Fitter, Electric Technician, Stove } \\
\text { and Air Heating Mechanic, Carpenter, }\end{array}$ & 22 \\
\hline III & $\begin{array}{l}\text { Crafts for commercial } \\
\text { needs }\end{array}$ & $\begin{array}{l}\text { Metal Worker, Surgical Instrument Maker, Precision Engineer, Refrigera- } \\
\text { tion Mechanic }\end{array}$ & 15 \\
\hline IV & $\begin{array}{l}\text { Motor Trades and } \\
\text { Repairs }\end{array}$ & Automotive Mechatronics Technician & 5 \\
\hline $\mathrm{V}$ & Food trades & Baker, Butcher, Pastry-cook & 5 \\
\hline VI & Health trades & Dental Technician & 2 \\
\hline VII & Crafts for private use & Hairdresser, Glass Blower, Locksmith, Smith, Ceramist & 9 \\
\hline
\end{tabular}




\subsection{Drivers of energy efficiency in SMEs}

The drivers used for the survey are based on those used by Cagno and Trianni (2013) who conducted a comprehensive literature review on the barriers and drivers of energy efficiency measures in SMEs. From this they derived 14 drivers based on the results from studies by Saygin et al. (2011); Thollander and Dotzauer (2010); Thollander and Ottoson (2008); CankaKilic and Kaya (2007); Reddy and Assenza (2007); del Rio Gonzalez (2005); Anderson and Newell (2004); Galitsky et al. (2004); de Groot et al. (2001); Worrell and Price (2001). Table 2 summarizes these 14 drivers (column 2) with a short description of each in column $3 .^{4}$

\section{Table 2}

Drivers for energy efficiency in SMEs used in the survey

\begin{tabular}{|c|c|c|}
\hline No. & Driver & Description / sub-driver \\
\hline 1 & Management sensitivity & Environmentally sensitized decision-maker / CEO / owner of the company \\
\hline \multirow[t]{4}{*}{2} & External Pressure & \\
\hline & & A: Increasing energy prices \\
\hline & & $\begin{array}{l}\text { B: Introduction / increases of fees on energy sources or pollution / } \\
\text { emissions }\end{array}$ \\
\hline & & $\begin{array}{l}\text { C: Introduction / increases of taxes on energy sources, pollution or } \\
\text { emissions }\end{array}$ \\
\hline 3 & Clients & Clients interested in and valuing energy efficiency or environmental protection \\
\hline 4 & Information on interventions & $\begin{array}{l}\text { Information on experiences of other similar companies which have successfully implemented } \\
\text { energy efficiency measures }\end{array}$ \\
\hline 5 & Information on practices & Information on energy efficient behavior \\
\hline 6 & Lower costs of consultancies & Importance of low-cost or free energy efficiency consultation \\
\hline 7 & $\begin{array}{l}\text { Access to energy efficiency } \\
\text { experts }\end{array}$ & $\begin{array}{l}\text { Importance of consultation about energy efficiency measures in own company } \\
\text { A: Firm-specific consultancy } \\
\text { B: General discussion about energy efficiency }\end{array}$ \\
\hline 8 & $\begin{array}{l}\text { Increase of internal competenc- } \\
\text { es }\end{array}$ & $\begin{array}{l}\text { A: One employee: Competences of one employee being responsible for energy } \\
\text { efficiency issues and searching for information on energy efficiency } \\
\text { B: Training: Employee attending training in energy efficiency }\end{array}$ \\
\hline 9 & Energy performance contracts & Energy performance contracting \\
\hline 10 & Allowances or public financing & $\begin{array}{l}\text { A: Allowances: Governmental allowances, financial grants, tax allowances } \\
\text { B: Cheap credits: Access to cheap credits }\end{array}$ \\
\hline 11 & Long-term benefits & Long-term benefits \\
\hline 12 & New solutions & Developing own energy efficiency solutions \\
\hline 13 & Anticipating regulatory issues & Anticipating planned or expected regulatory requirements \\
\hline 14 & $\begin{array}{l}\text { Great ambition and entrepre- } \\
\text { neurial mind }\end{array}$ & $\begin{array}{l}\text { Open-mindedness of decision maker / management / owner for the adoption of new technolo- } \\
\text { gies }\end{array}$ \\
\hline I & & A: Initial idea of energy efficiency measure came from within the company \\
\hline & & B: Initial idea of energy efficiency measure came from outside the company \\
\hline II & & External consultation was decisive for final decision for the energy efficiency measure \\
\hline III & & One person in the company in charge of energy efficiency issues and searching for information \\
\hline
\end{tabular}

\footnotetext{
${ }^{4}$ For further description of the drivers see Cagno and Trianni (2013 p. 270).
} 
I use sub-drivers to obtain more detailed results instead of only using the different drivers, namely, 'external pressure’, 'allowances and public financing', 'increase of internal competence' and 'access to energy efficiency experts' (see Figure 2).

Figure 2

Sub-division of Drivers for energy efficiency in SMEs
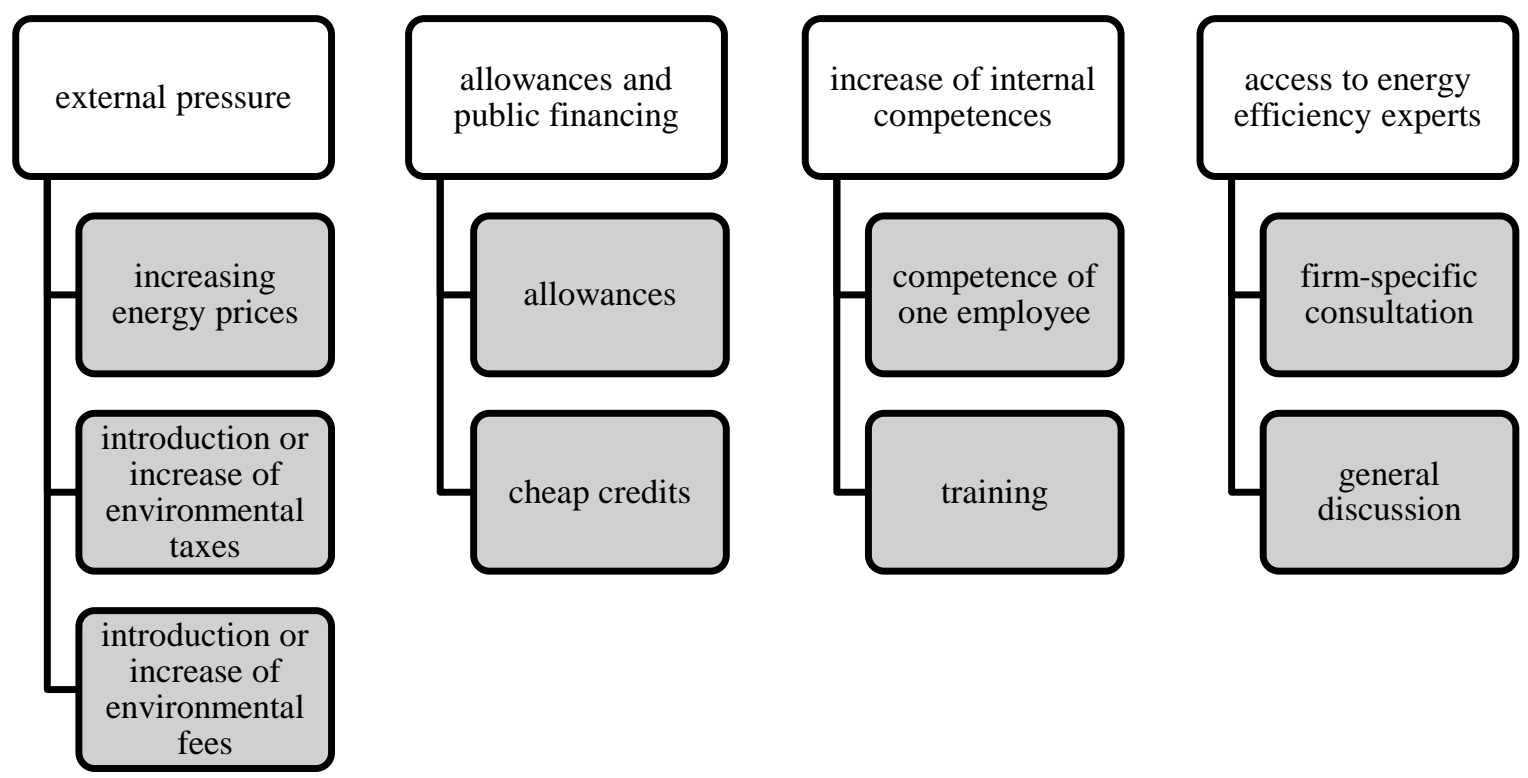

Thus, 'external pressure' is sub-divided into 'increasing energy prices', 'the introduction or increase of environmental fees' on energy sources, pollution or emissions as well as 'the introduction or increase of environmental taxes' on energy sources, pollution or emissions in order to gather information on whether taxes, fees or prices are more relevant to the implementation of energy efficiency measures. The driver 'allowances or public financing' is divided into ‘allowances' (including governmental allowances, financial grants and tax allowances) and 'cheap credits' as this sub-division is essential for policy makers in order to know which financial support programs to focus on. Furthermore, 'increase of internal competencies' is divided into the drivers 'competencies of one employee' and 'training'. The former means one employee being responsible for energy efficiency issues and searching for information on the topic energy efficiency while the latter is controlling for the importance of employees attending training.

Finally, the driver 'access to energy efficiency experts' is split into 'firm-specific consultation' and 'general discussion' in order to determine whether it is more important for companies to receive firm-specific consultation or if they preferred general information on energy efficiency measures. 
The last two subdivisions of the drives were added as the expert interviews suggested differences in the importance of the sub-drivers for SMEs. The expert interviews further pointed to the important role of external consultation for the company's decisions for adopting energy efficiency measures. Therefore, the following polar questions were added to the survey:

I. Did the initial idea for the energy efficiency measure come from within or outside the company?

This question allows me to draw conclusions on whether companies actually have an intrinsic motivation to invest in energy efficiency measure or whether its motivation first came from outside. The latter would imply a stronger focus on proactive information for SMEs.

II. Was external consultation decisive for the final decision for adopting an energy efficiency measure?

Although I control for the importance of access to energy efficiency experts and the costs of consultation, this question aims at learning whether a consultant brought to the company's attention the opportunities for energy efficiency measures and if this finally triggered the energy efficiency investment. If this was the case, it would indicate that the consultation was the decisive factor that led to the final decision for adopting an energy efficiency measure. This would imply stronger support for consultation regarding energy efficiency in SMEs.

III. Is one employee or person responsible for energy efficiency issues by focusing particularly on this in the company and searching for such information, if needed?

If the company answered the question in the positive, they were further asked whether the competencies of this employee were important for the implementation of the energy efficiency measure ['increasing internal competencies (one employee)’].

\section{Results}

Figure 3 shows the results of the analysis using the data from all the companies. The drivers are ranked according to their importance for the companies with " 1 " meaning being not important at all and “4” being very important. The scores for each driver of Cagno and Trianni's study are represented by the light grey bars. The detailed results of the analysis by firm size (Table A1), turnover (Table A2) and energy intensity (Table A3) as well as investment costs (Table A4) are reported in the appendix. 
Figure 3

Perceived Drivers - total sample

Increase of internal competences (training)

Information on interventions

Access to energy efficiency experts (general discussion)

New solutions

Allowances or public financing (cheap credits)

Lower costs of consultancies

External pressure (environmental taxes)

External pressure (environmental fees)

Energy performance contracts

Allowances or public financing (governmental allowances)

Clients

Anticipating regulatory issues

Access to energy efficiency experts (firm-specific consultation)

Information on practices / behavior

Management sensitivity

External pressure (rising energy prices)

Increase of internal competences (competences of employee)

Great ambition and entrepreneurial mind

Long-term benefits
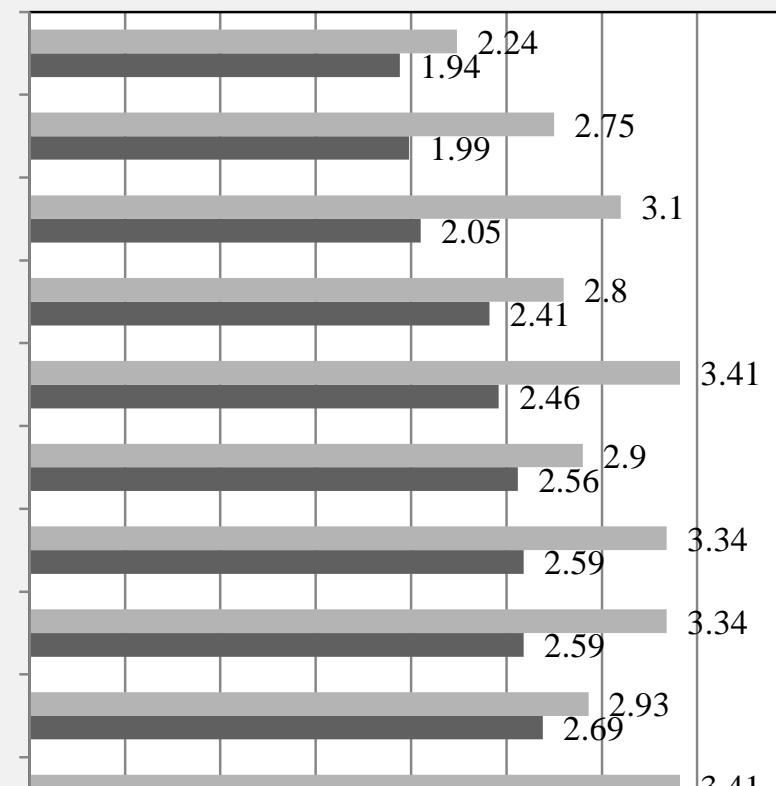

$-\frac{10}{20}$

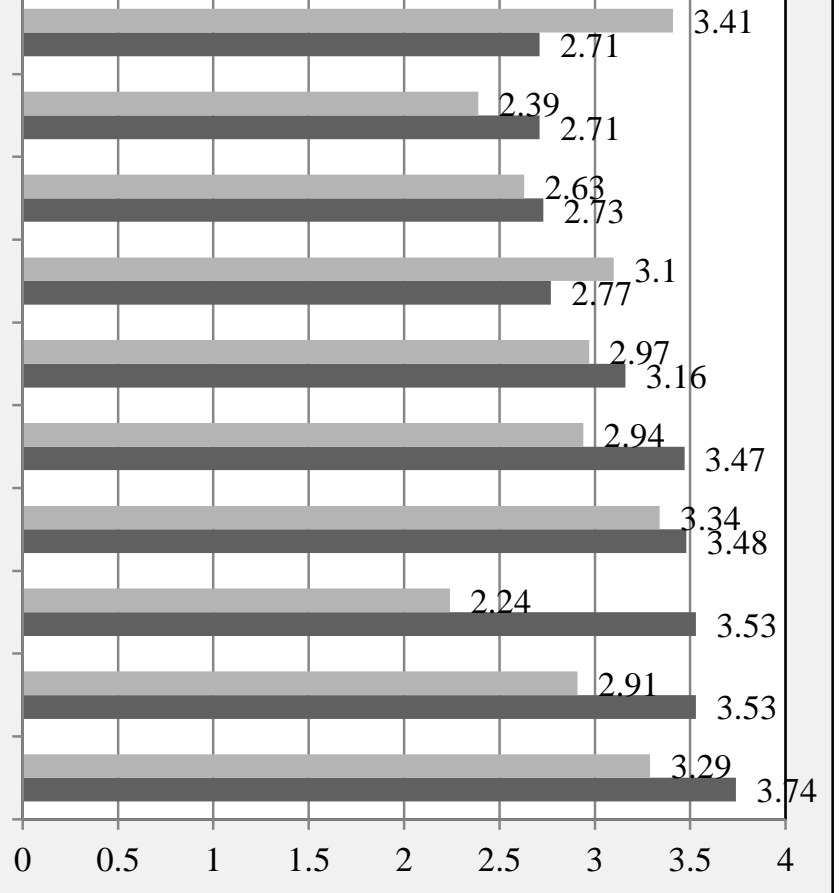

- Cagno / Trianni $\quad$ Thonipara

Note: “1” meaning "not important”, “2” meaning "less important”, “3” meaning "somewhat important” and "4” meaning "very important”

From the carried out analysis following results are obtained:

\subsection{Management Characteristics}

In this sample of small companies with low turnovers, 'management sensitivity' and 'great ambition and entrepreneurial mind', hence, management characteristics are ranked among the highest drivers, whereas these same drivers played a rather average role in the sample used by Cagno and Trianni (see Figure 4). The results show that even for very high investment costs, 
management sensitivity was a very important driver. Thus, whether an energy efficiency measure is implemented or not is to a large extent dependent on the open-mindedness of the decision-maker toward the adoption of new technologies as well as the environmental sensitivity of this person. Within the sample, management sensitivity to environmental issues was ranked as the most important driver (4.00) by all one-person companies, all small companies with 10-19 employees (Table A1), and by all companies with low turnovers (<50,000 Euros, Table A2). This is further evidence of the special importance of management sensitivity in small companies.

\section{Figure 4}

Perceived importance of "great ambition and entrepreneurial mind" and "management sensitivity"

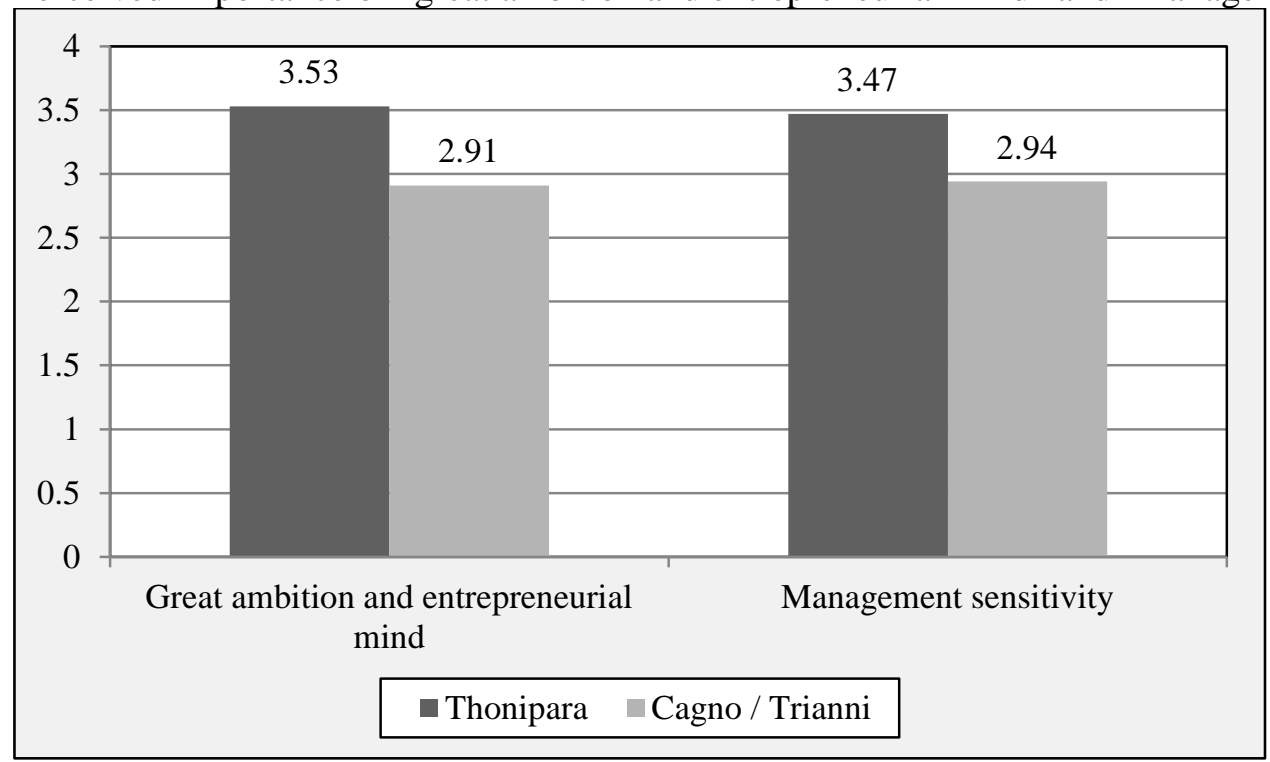

Note: “1” meaning “not important”, “2” meaning “less important”, “3” meaning “somewhat important” and “4” meaning “very important”

The interviews suggest that this is due to a lack of time and missing in-house capacities. Small companies, compared to larger ones, often do not have one or several employees who are in charge of energy efficiency matters. This argument is also reflected in the analysis of survey Question III. In small companies with up to four persons, only 25-33\% have one employee responsible for energy efficiency matters and, with an increase in firm size, this number becomes larger. In companies with 50 or more persons, $78 \%$ of them have one person in charge of energy efficiency. Hence, with no employees assigned the responsibility for energy efficiency, decisions about the matter depends largely on the manager's motivation and environmental sensitivity.

\section{Result 1: In small companies, energy efficiency measures are primarily driven by management's sensitivity.}




\subsection{Financial Support Programs}

'Allowances and public financing' were perceived as the main driver in Cagno and Trianni's (2013) sample, while for this study, they were ranked below average with allowances being considerably more important than low-cost credits. This could be due to the fact that credits have been historically low in Germany in the past ten years. One would expect governmental allowances and financial support to be very important for small companies and those with low turnover. However, the results (see Figure 5) show that financial support by governmental allowances or low-cost credits did not play a role in one-person companies (1.33) and a rather subordinated one in small companies with up to 9 persons $(1.67-2.50)$, whereas, they played a leading role in companies with 10-19 persons (3.67) and with more persons ( 3.5).

Figure 5

Perceived importance of allowances or public financing

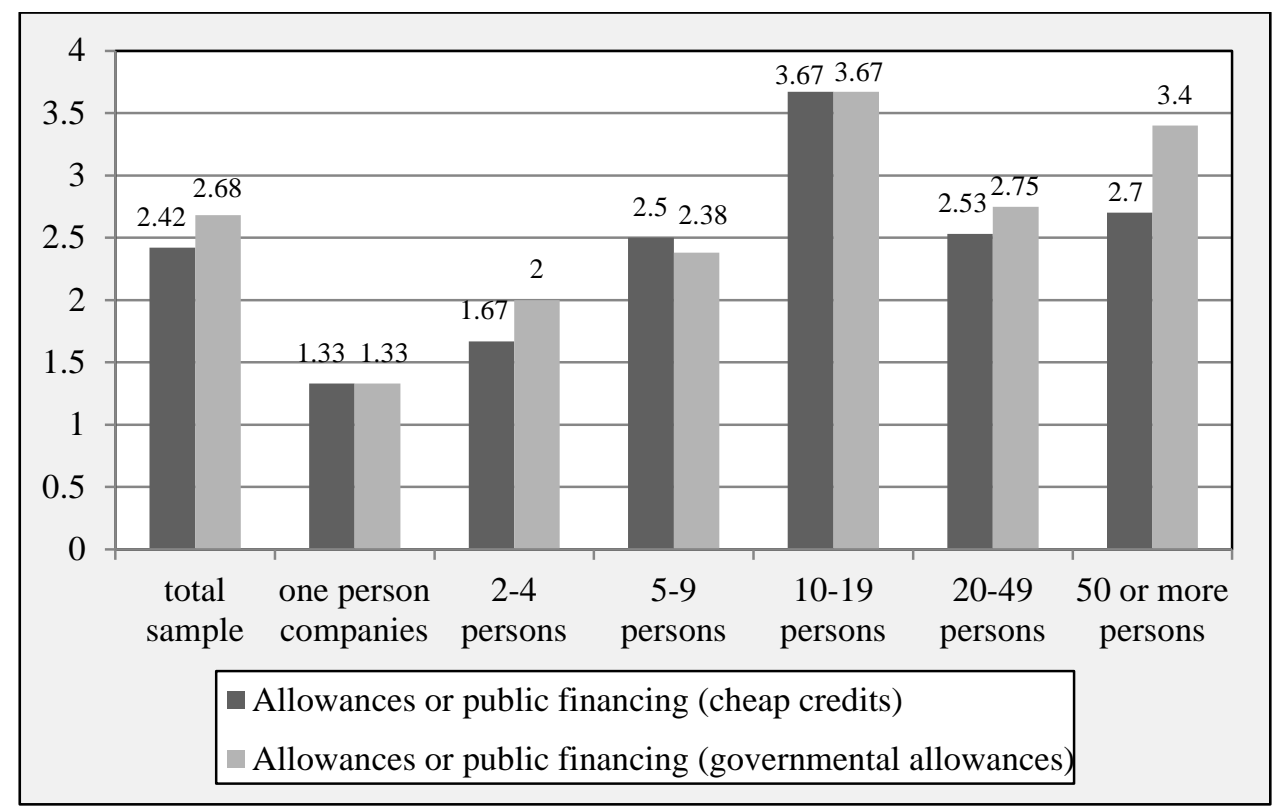

Note: “1” meaning “not important”, “2” meaning “less important”, “3” meaning "somewhat important” and “4” meaning “very important”

The analysis by firm size, turnover and investment costs further reasserts that public financing becomes more important with increasing firm size, turnover and investment costs. From the exploratory interviews and the survey, two explanations for these results are possible. First of all, the median values of investment costs show that smaller companies invest rather low sums in energy efficiency measures, whereas investment costs increase with the firm size. For example, a one-person company invests about 1,350 Euros and a company with more than 50 employees around 250,000 Euros. Furthermore, the results show that allowances and cheap 
credits were important drivers for high cost investments starting from 5,000 up to 500,000 Euros. For investments with lower costs than 5,000 Euros, allowances and cheap credits were not important for investments. Thus, the low importance of public financing in small companies could be explained by the low investment costs for which no public financial support is needed. However, another factor is brought up by the companies during the in-depth interviews.

The exploratory interviews revealed that many of the interviewees do not feel that their needs were addressed by governmental allowances which seemed to be aimed at the bigger companies. On my broaching the subject again, the companies stated that the administrative burden was one of the main obstacles. The fixed costs for the applications for support programs are perceived more burdensome by smaller companies as in most cases, they are not likely to have one employee who specialized in applying for public financial support. On the other hand, the larger companies have the ability to overcome these hurdles as they can more easily dedicate an employee to the task. Thus, a lack of allowance or public financing programs tailored to the needs of smaller firms (with higher flexibility, lower bureaucratic burdens, and the inclusion of small investments) could be a reason for this driver's low score.

Again, these results point to the absence of in-house capacities in smaller firms compared to the larger ones which are able to put these in place for the application for public financial support programs.

\section{Result 2: $\quad$ Financial support programs are less relevant for smaller SMEs due to missing in-house capacities and the high bureaucratic burdens.}

\subsection{Long-term benefits}

The vast majority of the companies interviewed considered long-term benefits as a very important driver of energy efficiency measures in SMEs. This driver was also ranked high (rank 3) by the sample of Cagno and Trianni's study. They explain the importance of this driver as a strategic factor that would increase the company's competitiveness by reducing costs in the future. This argument was also brought forward by Cote et al. (2006), Thollander and Ottoson (2008) as well as Hasanbeigi et al. (2009).

For the SMEs considered in this study, this driver needs to be interpreted in a slightly different way as the exploratory interviews showed. For the interviewed companies long-term benefits does not necessarily mean a competitive advantage but rather the importance of the investment being paid off at all at some point in the future as the amortization time is longer in these companies. This is for two reasons. First, for the occupations represented in this sam- 
ple, machines are only used for about 8 hours per day and stand idle during the other 16 hours. There are no night shifts as it is the case in larger industrial manufacturing companies with a high level of automation. Therefore, the amortisation time takes about two to three times longer for these small companies (Schwartz and Weiss 2013). Second, the occupations considered in this study have high energy costs related to their revenues, however, these were comparatively lower when compared to other industrial companies. This means that the investments in energy efficiency measures create a higher financial burden and increases in their competitiveness can hardly be reached. Thus, long-term benefits are extremely important, in the sense of the investment costs being paid off. For this reason, some of the companies stated that larger investments are often done only as part of a replacement investment for which the costs would nevertheless have occurred.

Hence, the results suggest that small companies, unlike larger ones, do not constantly think about efficiency improvements and cost advantages gained through energy efficiency measures. Instead, they have a discrete point in time when replacement investments are necessary. Therefore, it is essential for policymakers to know these special moments in time as they are very important with regard to the openness of small companies to receive information or consultation on energy efficiency measures.

\section{Result 3: In small companies with low turnover, energy efficiency measures are implemented as part of replacement investments.}

\subsection{Role of external consultants and access to information}

As Chapter 3.3 showed, it is essential to know at which point in time small companies need consultation and so here, the findings of the form of consultation are analyzed. The analysis shows that although access to energy efficiency experts is overall not ranked as high as in the sample by Cagno and Trianni (2013), a clear difference between general consultation (2.05) and firm-specific consultation (2.77) can be noticed. The subdivision into two drivers shows clearly that firm-specific consultancy is noticeably more conducive to the implementation of energy efficiency measures in smaller companies than general access to an energy efficiency expert or the general discussion about energy efficiency issues in a company with an energy efficiency expert.

On the other hand, factors which provide general information, such as, a lower cost of consultancy, talking to energy efficiency experts about general energy efficiency issues, and the training of employees in energy efficiency were for these companies relatively more important drivers than in smaller companies with low turnovers for which firm-specific consul- 
tancy was more important. This suggests that larger companies use different methods in order to increase internal competencies in order to prepare and plan an energy efficiency measure on their own. This concurs with the results presented in Chapter 3.2 which showed that building up in-house capacities could be more cost-effective in the long-run for larger companies which have the capacity to have one employee dedicated to energy efficiency issues and acquiring information. By continuously optimizing, applying for financial support and becoming more energy efficient, these companies can reduce their costs and become more competitive.

Furthermore, the results suggest the presence of strong differences between companies with low turnovers and larger ones with higher turnovers in the terms of the role of external consultation. For $67 \%$ of the companies with a turnover of less than 125,000 Euros, the initial idea of an energy efficiency measure came from outside the company. In addition to this, in $75 \%$ of the companies with a turnover between 50,000 and 125,000 Euros, external consultation was decisive in the implementation of an energy efficiency measure. Thus, whether an energy efficiency investment was implemented or not was highly dependent on the role of external consultants. In contrast to this, the results show that in the companies with more employees and higher turnovers and/or higher investment costs, the initial idea for an energy efficiency measure comes in almost all cases from within the companies. In these companies, external energy consultants did not have a triggering effect on the implementation of an energy efficiency measure. However, the companies use information from outside in order to build up in-house capacity. General consultation was conducive to this, but not for triggering it.

\section{Figure 6}

Share of companies with initial idea from within or outside the company by turnover

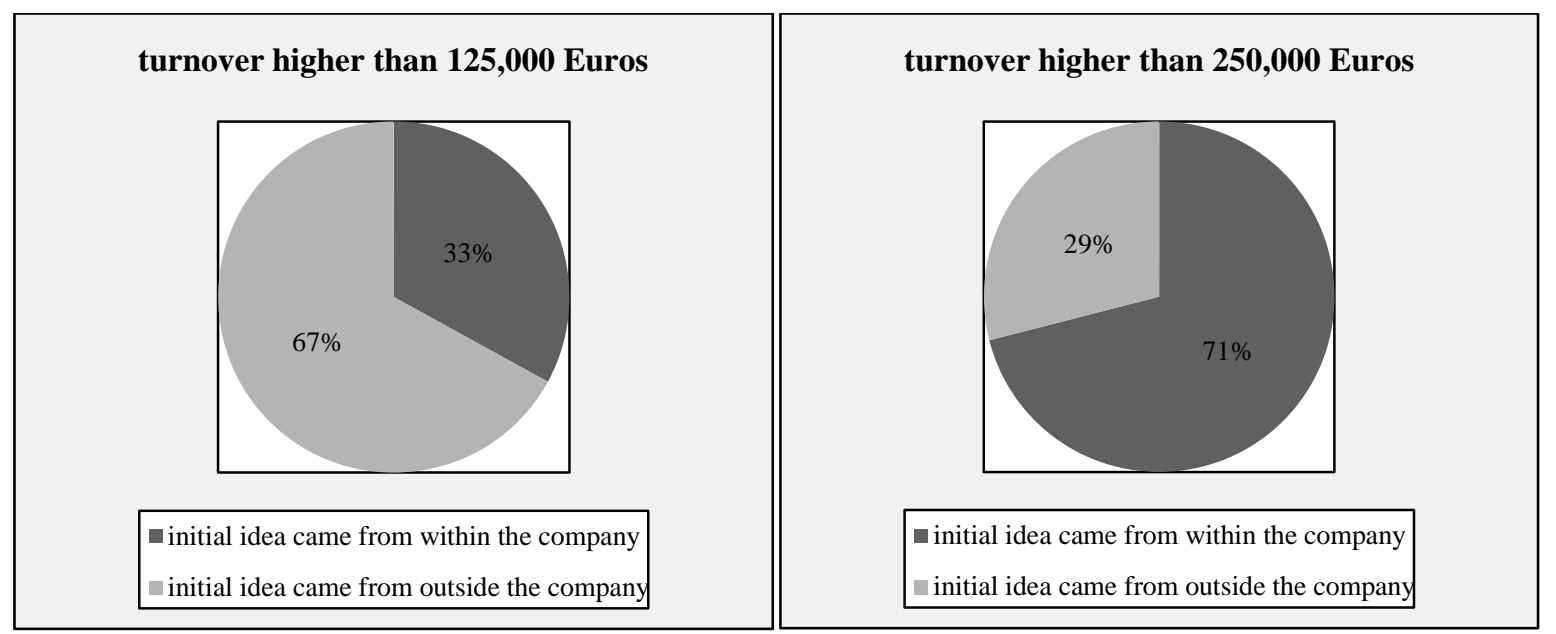


Therefore, these results combined with those of Chapters 3.1.-3.3, would seem to suggest that small companies do not want to build up in-house-capacities with regards to information on energy efficiency measures. Instead, these companies have certain points in time when replacement investments are necessary. At these moments, small companies need concrete, firm-specific consultation for this particular investment which would be a more rational and cost-efficient way for them than building up in-house capacities in the long run. Larger companies, on the other hand, use general information from outside to build up their in-house capacities.

\section{Result 4: Proactive and firm-specific consultation by external consultants at specific points in time is particularly important for small companies with low turnovers.}

\section{Result 5: Building up in-house capacity and acquiring information are important drivers for energy efficiency measures in larger companies with higher turnover.}

\section{Conclusion and implications for policy and research}

This paper analyzed the importance of different drivers of energy efficiency in SMEs and serves the purpose to generate hypotheses for further research. As former studies have focused on larger SMEs with higher turnovers, this one uses a sample of smaller SMEs with lower turnovers. The method used for the research is based on Cagno and Trianni's (2013) study on the drivers of energy efficiency in high-turnover and high-tech industrial SMEs. This was done in order to allow for a direct comparison between the samples in both studies. Additionally, I also conducted in-depth expert interviews and a survey extended by open and exploratory interviews with the companies.

While Cagno and Trianni (2013) argue that energy efficiency measures were mainly driven by financial support programs and other economic drivers as a strategic step towards more competitiveness. However, the results of this study suggest that managerial characteristics are more important for small companies with low turnovers. This is due to the missing in-house capacities in smaller SMEs which then requires management's own motivation or environmental sensitivity for initiating energy efficiency measures. These missing in-house capacities are also one reason for the low importance of financial support programs which are not attractive to small companies due to their high bureaucratic burden. Instead, smaller companies with low turnovers appreciate firm-specific consultancy by external consultants at a certain point in 
time when replacement investments are necessary. On the other hand, larger companies build up long term in-house capacities by acquiring general information. These in-house capacities are particularly important for applications for public financial support programs which are a key driver in larger companies. Given that these companies are in most cases, intrinsically motivated and external consultants play a minor role, building up in-house capacities is essential for continuous energy efficiency improvements.

The results can be summed up in five preliminary conclusions which should be understood as hypotheses which further quantitative research should validate:

Result 1: In small companies, energy efficiency measures are primarily driven by management sensitivity.

Result 2: $\quad$ Financial support programs are less relevant for smaller SMEs due to missing in-house capacities and high bureaucratic burdens.

Result 3: In small companies with low turnover, energy efficiency measures are implemented as part of replacement investments.

Result 4: $\quad$ Proactive and firm-specific consultation by external consultants at specific points in time is particularly important for small companies with low turnovers.

Result 5: $\quad$ Building up in-house capacity and acquiring information are important drivers for energy efficiency measures in larger companies with higher turnover.

The results have several implications for policies promoting energy efficiency measures in SMEs. First, the results suggest that policymakers should focus on tools targeting the management's sensitivity as most energy efficiency measures are driven by the management's own motivation. This could be done by having campaigns to disseminate information and raise awareness through consultations with chambers of crafts and by holding information events or showcases.

Second, policymakers can further promote investments in high-cost energy efficiency measures through public financing programs which should be designed more flexibly and be less bureaucratic. This could motivate smaller companies to take advantage of these programs as they have so far perceived public financing programs as not being suitable for their firm size. Higher acceptance could also be achieved by marketing activities targeted specifically at these small businesses. The analysis shows that larger companies, companies with high turnover and investment costs can best be supported by general information and mentoring programs Therefore, for smaller companies and those with lower turnover, policymakers should focus on firm-specific consultancy and close partnership during the planning and implementa- 
tion process. In these companies, it would also be advisable to proactively approach the companies and suggest company specific energy efficiency measures because the first idea for doing this often comes from outside the company.

Last but not least, moments in time play an important role. The findings from the study suggest that small companies only become involved in energy efficiency measures once replacement investments are necessary. At this specific point in time, small companies need firm-specific consultation. Hence, it would be necessary to reach the companies at this very moment in time.

With the results, I contribute to the general understanding of the drivers of energy efficiency in SMEs. Earlier research focused on high-tech, high-turnover and larger companies, therefore, these results are a first step towards a more comprehensive understanding of the drivers of energy efficiency in SMEs by shedding light on SMEs that are smaller, mostly laborintensive, and with low turnover. The exploratory and qualitative approach of this study, however, does not allow drawing representative conclusions. Therefore, the results should be understood as hypotheses which should be validated by a broader quantitative analysis.

Given that the results have shown that the effects brought about by firm size often correlated with those from turnover size and investment costs, it would be necessary to further quantitatively assess whether the effects are driven by firm size, turnover or investment costs. For this purpose, an instrumental variable approach could enhance clearer assertions.

In light of the current global efforts to reduce carbon dioxide emissions and the urgency to mitigate climate change, the findings from this study serve as a valuable contribution to the body of knowledge about how to achieve a low carbon and energy efficient SME sector. 


\section{References}

Anderson, S.T., and Newell, R.G. 2004. "Information Programs for Technology Adoption: The Case of Energy-Efficiency Audits.” Resource Energy Economics 26 (1): 27-50.

Arens, M., Worrell, E. and Eichhammer, W. 2017. "Drivers and Barriers to the Diffusion of Energy-Efficient Technologies—a Plant-Level Analysis of the German Steel Industry.” Energy Efficiency 10 (2): 441-57.

Cagno, E., and Trianni, A. 2013. "Exploring Drivers for Energy Efficiency within Small- and Medium-Sized Enterprises: First Evidences from Italian Manufacturing Enterprises.” Applied Energy 104 (April): 276-85.

CankaKilic, F., and Kaya, D. 2007. “Energy Production, Consumption, Policies, and Recent Developments in Turkey.” Renew Sustain Energy Rev 11 (6): 1312-20.

Cote, R., Booth, A. and Louis, B. 2006. “Eco-Efficiency and SMEs in Nova Scotia.” Journal Clean Production 14 (6-7): 542-50.

Council of the European Union. 2019. “The New Commission’s Energy Policy Priorities.” https://www.consilium.europa.eu/media/41441/the-new-commission-s-energy-policypriorities.pdf (accessed 13.01.2020).

De Groot, F.H.L., Verhoef, E.T. and Nijkamp, P. 2001. “Energy Savings by Firms: DecisionMaking, Barriers and Policies.” Energy Economics 23 (6): 717-40.

Del Rio Gonzalez, P. 2005. “Analysing the Factors Influencing Clean Technology Adoption: A Study of the Spanish Pulp and Paper Industry.” Business Strategy Environment 14 (1): 20-37.

Dukan, M. 2019. “Energy Efficiency Policy Instruments in the European Union.” The Climate Policy Info Hub. 2019. https://climatepolicyinfohub.eu/energy-efficiency-policyinstruments-european-union (accessed 13.01.2020).

European Commission. 2019. “Energy Efficiency in Small and Medium-Sized Enterprises.” 2019. https://ec.europa.eu/energy/intelligent/projects/en/projects/engine (accessed 13.01.2020).

Federal and State Statistical Offices. 2019. “Database.” 2019. https://www.statistikportal.de/de/statistische-aemter.

Galitsky, C., Price, L. and Worrell, E. 2004. Energy Efficiency Programs and Policies in the Industrial Sector in Industrialized Countries. Berkeley. 
Hasanbeigi, A., Menke, C. and Pont, P. 2009. “Barriers to Energy Efficiency Improvement and Decision-Making Behavior in Thai Industry.” Energy Efficiency2 3 (1): 33-52.

Önüt, S., and Soner, S. 2007. “Analysis of Energy Use and Efficiency in Turkish Manufacturing Sector SMEs.” Energy Conversion and Management 48 (2): 384-94.

Saygin, D. E., Worrel, Patel, M.K. and Gielen, D. 2011. "Benchmarking the Energy Use of Energy-Intensive Industries in Industrialized and in Developing Countries.” Energy 36 (11): 6661-73.

Schwartz, M, and Weiss, P. 2013. "Das Handwerk in Deutschland: Meisterlich Bei Energieeffizienz.” KfW Research Studien Und Materialien. https://www.kfw.de/DownloadCenter/Konzernthemen/Research/PDF-Dokumente-Studien-undMaterialien/Gründungshemmnisse-April-2013.pdf (accessed 13.01.2020).

Sudhakara, R. B. 2013. "Barriers and Drivers to Energy Efficiency - A New Taxonomical Approach.” Energy Conversion and Management 74 (October): 403-16.

Tanaka, K. 2011. "Review of Policies and Measures for Energy Efficiency in Industry Sector.” Energy Policy 39 (10). Elsevier: 6532-50.

Thollander, P. and Dotzauer, E. 2010. “An Energy Efficiency Program for Swedish Industrial Small- and Medium-Sized Enterprises.” Journal of Cleaner Production 18 (13): 1339-46.

Thollander, P., and Ottoson, M. 2008. “An Energy Efficient Swedish Pulp and Paper Industry - Exploring Barriers to and Driving Forces for Cost-Effective Energy Efficiency Investments.” Energy Efficiency 1 (1): 21-34.

Trianni, A., and Cagno, E. 2012. "Dealing with Barriers to Energy Efficiency and SMEs: Some Empirical Evidences.” Energy 37 (1). Pergamon: 494-504.

Worrell, E, and Price, L. 2001. "Policy Scenarios for Energy Efficiendcy Improvement in Industry.” Energy, no. 29: 1223-41. 


\section{Appendix}

Table A1

Perceived drivers in companies by firm size

\begin{tabular}{|c|c|c|c|c|c|c|c|c|}
\hline Rank & Driver & Total sample & $\begin{array}{c}\text { one person } \\
\mathrm{N}=3\end{array}$ & $\begin{array}{c}2-4 \text { persons } \\
\mathrm{N}=9\end{array}$ & $\begin{array}{c}\text { 5-9 persons } \\
\text { N=16 }\end{array}$ & $\begin{array}{l}10-19 \text { per- } \\
\text { sons N=16 }\end{array}$ & $\begin{array}{c}20-49 \\
\text { persons } \\
\mathrm{N}=16 \\
\end{array}$ & $\begin{array}{c}50 \text { or more } \\
\text { persons } \\
\mathrm{N}=10\end{array}$ \\
\hline 1 & Long-term benefits & 3.73 & 3.33 & 3.44 & 3.75 & 3.67 & 4.00 & 3.78 \\
\hline 2 & Great ambition and entrepreneurial mind & 3.55 & 3.33 & 3.63 & 3.50 & 3.67 & 3.50 & 3.70 \\
\hline 3 & Increase of internal competences (competences of employee) & 3.53 & 1.00 & 4.00 & 3.67 & 3.00 & 3.29 & 3.43 \\
\hline 4 & External pressure (rising energy prices) & 3.47 & 2.67 & 3.78 & 3.63 & 3.33 & 3.38 & 3.50 \\
\hline 5 & Management sensitivity & 3.46 & 4.00 & 3.22 & 3.56 & 4.00 & 3.38 & 3.40 \\
\hline 6 & Information on practices / behavior & 3.16 & 3.00 & 2.75 & 3.38 & 3.67 & 3.00 & 3.40 \\
\hline 7 & Access to energy efficiency expert (consultancy) & 2.77 & 3.00 & 2.00 & 2.50 & 2.00 & 3.33 & 2.60 \\
\hline 8 & Anticipating regulatory issues & 2.73 & 1.67 & 2.50 & 2.81 & 3.00 & 2.81 & 3.10 \\
\hline 9 & Clients & 2.72 & 1.67 & 2.89 & 2.56 & 3.33 & 2.69 & 3.30 \\
\hline 10 & Energy performance contracts & 2.68 & 1.33 & 3.00 & 2.75 & 3.00 & 3.19 & 2.30 \\
\hline 11 & Allowances or public financing (governmental allowances) & 2.68 & 1.33 & 2.00 & 2.38 & 3.67 & 2.75 & 3.40 \\
\hline 12 & Lower costs of consultancies & 2.56 & 2.00 & 1.78 & 2.88 & 2.67 & 2.57 & 2.30 \\
\hline 13 & External pressure (environmental taxes) & 2.55 & 2.00 & 3.00 & 2.47 & 2.67 & 2.25 & 2.67 \\
\hline 14 & External pressure (environmental fees) & 2.55 & 2.33 & 2.22 & 2.73 & 3.33 & 2.38 & 2.30 \\
\hline 15 & Allowances or public financing (cheap credits) & 2.42 & 1.33 & 1.67 & 2.50 & 3.67 & 2.53 & 2.70 \\
\hline 16 & New solutions & 2.41 & 2.33 & 2.22 & 2.63 & 3.00 & 2.38 & 2.80 \\
\hline 17 & Access to energy efficiency experts (discuss / talk to ...) & 2.05 & 1.33 & 1.11 & 2.00 & 2.33 & 2.38 & 2.20 \\
\hline 18 & Information on interventions & 1.99 & 2.33 & 1.67 & 1.69 & 3.00 & 2.19 & 2.30 \\
\hline \multirow[t]{7}{*}{19} & Increase of internal competences (training) & 1.94 & 1.00 & 1.50 & 1.94 & 2.00 & 1.75 & 2.38 \\
\hline & Idea of energy efficiency measure came from within the company & $72 \%$ & $67 \%$ & $71 \%$ & $71 \%$ & $67 \%$ & $75 \%$ & $87 \%$ \\
\hline & Idea of energy efficiency measure came from outside the company & $28 \%$ & $33 \%$ & $29 \%$ & $29 \%$ & $33 \%$ & $25 \%$ & $13 \%$ \\
\hline & Idea of energy efficiency measure came from external consultant & $27 \%$ & $33 \%$ & $37 \%$ & $13 \%$ & $33 \%$ & $21 \%$ & $22 \%$ \\
\hline & One person in company in charge of search for information on energy efficiency measures & $56 \%$ & $33 \%$ & $25 \%$ & $75 \%$ & $33 \%$ & $44 \%$ & $78 \%$ \\
\hline & Median of yearly energy costs & 15,000 & 1,900 & 3,500 & 6,000 & 25,000 & 17,500 & 900,000 \\
\hline & Median of investment costs & 16,000 & 1,350 & 3,000 & 11,500 & 16,000 & 105,00 & 250,000 \\
\hline
\end{tabular}


Table A2

Perceived drivers in companies by turnover sizes

\begin{tabular}{|c|c|c|c|c|c|c|c|}
\hline Rank & Driver & Total & $\begin{array}{c}\text { less than } \\
50,000 \text { Euros } \\
\mathrm{N}=4\end{array}$ & $\begin{array}{c}50,000- \\
125,000 \text { Euros } \\
\mathrm{N}=4\end{array}$ & $\begin{array}{c}125,000- \\
250,000 \text { Euros } \\
\mathrm{N}=3\end{array}$ & $\begin{array}{c}250,000- \\
500,000 \text { Euros } \\
\mathrm{N}=10\end{array}$ & $\begin{array}{c}500,000- \\
5,000,000 \text { Euro } \\
\mathrm{N}=32\end{array}$ \\
\hline 1 & Long-term benefits & 3.73 & 4.00 & 3.50 & 3.33 & 3.40 & 3.81 \\
\hline 2 & Great ambition and entrepreneurial mind & 3.55 & 4.00 & 3.67 & 3.33 & 3.20 & 3.59 \\
\hline 3 & Increase of internal competences (competences of employee) & 3.53 & 4.00 & 3.00 & 4.00 & 4.00 & 3.56 \\
\hline 4 & External pressure (rising energy prices) & 3.47 & 3.50 & 3.50 & 3.33 & 3.70 & 3.38 \\
\hline 5 & Management sensitivity & 3.46 & 4.00 & 3.00 & 3.00 & 3.10 & 3.47 \\
\hline 6 & Information on practices / behavior & 3.16 & 3.33 & 3.00 & 3.33 & 2.70 & 3.16 \\
\hline 7 & Access to energy efficiency experts (consultancy) & 2.77 & 2.79 & 3.00 & 2.50 & 3.00 & 2.79 \\
\hline 8 & Anticipating regulatory issues & 2.73 & 2.33 & 3.00 & 3.00 & 2.10 & 2.84 \\
\hline 9 & Clients & 2.72 & 3.25 & 3.25 & 2.67 & 2.50 & 2.56 \\
\hline 10 & Energy performance contracts & 2.68 & 2.50 & 3.25 & 2.67 & 2.30 & 2.75 \\
\hline 11 & Allowances or public financing (governmental allowances) & 2.68 & 2.50 & 1.50 & 2.67 & 2.40 & 2.72 \\
\hline 12 & Lower costs of consultancies & 2.56 & 3.25 & 1.00 & 3.33 & 2.70 & 2.58 \\
\hline 13 & External pressure (environmental taxes) & 2.55 & 3.25 & 2.50 & 2.00 & 2.60 & 2.48 \\
\hline 14 & External pressure (environmental fees) & 2.55 & 3.00 & 2.00 & 2.00 & 2.70 & 2.66 \\
\hline 15 & Allowances or public financing (cheap credits) & 2.42 & 2.00 & 1.50 & 2.67 & 2.30 & 2.42 \\
\hline 16 & New solutions & 2.41 & 3.50 & 2.25 & 2.67 & 1.60 & 2.50 \\
\hline 17 & Access to energy efficiency experts (discuss / talk to ...) & 2.05 & 1.25 & 1.00 & 3.00 & 2.40 & 2.19 \\
\hline 18 & Information on interventions & 1.99 & 1.75 & 2.25 & 2.00 & 2.10 & 1.91 \\
\hline \multirow[t]{7}{*}{19} & Increase of internal competences (training) & 1.94 & 2.67 & 1.25 & 1.33 & 1.80 & 1.88 \\
\hline & Idea of energy efficiency measure came from within the company & $72 \%$ & $33 \%$ & $33 \%$ & $67 \%$ & $70 \%$ & $71 \%$ \\
\hline & Idea of energy efficiency measure came from outside the company & $28 \%$ & $67 \%$ & $67 \%$ & $33 \%$ & $30 \%$ & $29 \%$ \\
\hline & Idea of energy efficiency measure came from external consultant & $27 \%$ & $33 \%$ & $75 \%$ & $33 \%$ & $30 \%$ & $28 \%$ \\
\hline & One person in company in charge of search for information on energy efficiency measures & $56 \%$ & $33 \%$ & $75 \%$ & $33 \%$ & $50 \%$ & $50 \%$ \\
\hline & Median of yearly energy costs & 15,000 & 2,750 & 1,300 & 18,750 & 5,000 & 20,000 \\
\hline & Median of investment costs & 16,000 & 1,000 & 2,500 & 6,400 & 5,000 & 41,000 \\
\hline
\end{tabular}


Table A3

Perceived drivers in energy intensive companies

\begin{tabular}{|c|c|c|c|c|}
\hline Rank & Driver & Total & $\begin{array}{c}\text { energy intensive } \\
\text { companies } N=26\end{array}$ & $\begin{array}{c}\text { not energy intensive com- } \\
\text { panies } \mathrm{N}=40\end{array}$ \\
\hline 1 & Long-term benefits & 3.73 & 3.73 & 3.78 \\
\hline 2 & Great ambition and entrepreneurial mind & 3.55 & 3.31 & 3.65 \\
\hline 3 & Increase of internal competences (competences of employee) & 3.53 & 3.36 & 3.52 \\
\hline 4 & External pressure (rising energy prices) & 3.47 & 3.46 & 3.51 \\
\hline 5 & Management sensitivity & 3.46 & 3.38 & 3.44 \\
\hline 6 & Information on practices / behavior & 3.16 & 3.08 & 3.23 \\
\hline 7 & Access to energy efficiency experts (consultancy) & 2.77 & 2.53 & 3.33 \\
\hline 8 & Anticipating regulatory issues & 2.73 & 2.54 & 2.83 \\
\hline 9 & Clients & 2.72 & 2.46 & 2.90 \\
\hline 10 & Energy performance contracts & 2.68 & 2.81 & 2.68 \\
\hline 11 & Allowances or public financing (governmental allowances) & 2.68 & 2.73 & 2.66 \\
\hline 12 & Lower costs of consultancies & 2.56 & 2.68 & 2.38 \\
\hline 13 & External pressure (environmental taxes) & 2.55 & 2.38 & 2.69 \\
\hline 14 & External pressure (environmental fees) & 2.55 & 2.38 & 2.73 \\
\hline 15 & Allowances or public financing (cheap credits) & 2.42 & 2.60 & 2.32 \\
\hline 16 & New solutions & 2.41 & 2.31 & 2.41 \\
\hline 17 & Access to energy efficiency experts (discuss / talk to ...) & 2.05 & 2.38 & 1.78 \\
\hline 18 & Information on interventions & 1.99 & 2.38 & 1.80 \\
\hline \multirow[t]{7}{*}{19} & Increase of internal competences (training) & 1.94 & 1.84 & 1.95 \\
\hline & Idea of energy efficiency measure came from within the company & $72 \%$ & $100 \%$ & $58 \%$ \\
\hline & Idea of energy efficiency measure came from outside the company & $28 \%$ & $0 \%$ & $42 \%$ \\
\hline & Idea of energy efficiency measure came from external consultant & $27 \%$ & $37 \%$ & $21 \%$ \\
\hline & One person in company in charge of search for information on energy efficiency measures & $56 \%$ & $44 \%$ & $55 \%$ \\
\hline & Median of yearly energy costs & 15,000 & 31,800 & 7,000 \\
\hline & Median of investment costs & 16,000 & 20,000 & 12,500 \\
\hline
\end{tabular}


Table A4

Perceived drivers in companies with energy efficiency investment costs of

\begin{tabular}{|c|c|c|c|c|c|}
\hline Rank & Driver & Total & $\begin{array}{l}\text { up to 5,000 Euros } \\
\qquad \mathrm{N}=18\end{array}$ & $\begin{array}{c}5,000 \text { Euros }-50,000 \\
\text { Euros } \\
\mathrm{N}=20\end{array}$ & $\begin{array}{l}\text { more than 50,000 Euros } \\
\qquad \mathrm{N}=15\end{array}$ \\
\hline 1 & Long-term benefits & 3.73 & 3.73 & 3.78 & \\
\hline 2 & Great ambition and entrepreneurial mind & 3.55 & 3.57 & 3.50 & 3.67 \\
\hline 3 & Increase of internal competences (competences of employee) & 3.53 & 3.29 & 3.64 & 3.67 \\
\hline 4 & External pressure (rising energy prices) & 3.47 & 3.50 & 3.50 & 3.80 \\
\hline 5 & Management sensitivity & 3.46 & 3.43 & 3.50 & 3.33 \\
\hline 6 & Information on practices / behavior & 3.16 & 3.08 & 3.16 & 3.27 \\
\hline 7 & Access to energy efficiency experts (consultancy) & 2.77 & 3.00 & 2.46 & 2.75 \\
\hline 8 & Anticipating regulatory issues & 2.73 & 2.85 & 2.32 & 3.20 \\
\hline 9 & Clients & 2.72 & 3.21 & 2.65 & 2.93 \\
\hline 10 & Energy performance contracts & 2.68 & 2.86 & 2.80 & 3.07 \\
\hline 11 & Allowances or public financing (governmental allowances) & 2.68 & 2.14 & 2.90 & 3.13 \\
\hline 12 & Lower costs of consultancies & 2.56 & 2.15 & 2.79 & 2.60 \\
\hline 13 & External pressure (environmental taxes) & 2.55 & 3.21 & 2.35 & 2.87 \\
\hline 14 & External pressure (environmental fees) & 2.55 & 2.93 & 2.55 & 3.00 \\
\hline 15 & Allowances or public financing (cheap credits) & 2.42 & 2.50 & 2.50 & 2.93 \\
\hline 16 & New solutions & 2.41 & 2.23 & 2.74 & 2.73 \\
\hline 17 & Access to energy efficiency experts (discuss / talk to ...) & 2.05 & 1.46 & 2.63 & 2.40 \\
\hline 18 & Information on interventions & 1.99 & 1.77 & 1.95 & 2.20 \\
\hline \multirow[t]{7}{*}{19} & Increase of internal competences (training) & 1.94 & 1.92 & 2.21 & 2.07 \\
\hline & Idea of energy efficiency measure came from within the company & $72 \%$ & $58 \%$ & $67 \%$ & $86 \%$ \\
\hline & Idea of energy efficiency measure came from outside the company & $28 \%$ & $42 \%$ & $33 \%$ & $14 \%$ \\
\hline & Idea of energy efficiency measure came from external consultant & $27 \%$ & $25 \%$ & $42 \%$ & $21 \%$ \\
\hline & One person in company in charge of search for information on energy efficiency measures & $56 \%$ & $54 \%$ & $58 \%$ & $60 \%$ \\
\hline & Median of yearly energy costs & 15,000 & 2,750 & 20,000 & 31,210 \\
\hline & Median of investment costs & 16,000 & 1,000 & 20,000 & 200,000 \\
\hline
\end{tabular}

